\author{
Universidade de São Paulo \\ Faculdade de Filosofia, Letras e Ciências Humanas \\ Departamento: Teoria Literária e Literatura Comparada
}

Rosa Walda Abreu M arquart

\title{
0 fiel e a pedra e as epopéias clássicas: diálogos e tessituras
}

São Paulo

2008 
ROSA WALDA ABREU MARQUART

\section{O fiel e a pedra e as epopéias clássicas: diálogos e tessituras}

Tese apresentada ao Departamento de Teoria Literária e Literatura Comparada, da Faculdade de Filosofia, Letras e Ciências Humanas, da Universidade de São Paulo, para obtenção do título de Doutora em Letras.

Área de concentração: Teoria Literária e Literatura Comparada Orientadora: Professora Dra. Sandra Margarida Nitrini

São Paulo 
Para

meus dois amados Brunos,

esposo e filho,

incansáveis incentivadores,

imprescindíveis

companheiros de jornada. 


\section{AGRADECIMENTOS}

À profa. Dra. Sandra Margarida Nitrini, pela paciente, amigável, mas sobretudo profícua orientação, essa caracterizada sumamente pelo respeito ao olhar do outro.

Aos professores doutores Antonio Medina e Cleusa Rios Pinheiro Passos, pelas importantes considerações feitas durante o exame de qualificação, bem como aos professores participantes da banca de defesa desta tese.

Aos professores Marcus Vinicius Mazzari, Andrea Saad Hossne, Ana Luiza Andrade, Ermelinda Ferreira, Claudia Luiza Caimmi, Leny da Silva Gomes, por ter dispensado tempo para correspondência sobre Osman Lins ou a teoria que pretendíamos usar como respaldo de nossa leitura.

Às filhas de Osman Lins, Letícia, Ângela e Litânia, pela simpática receptividade ao esboço deste projeto, quando de sua visita à Universidade de São Paulo, por ocasião do Colóquio sobre Osman Lins.

A Darci Datanazio, Jucimara Tarricone, Maria Teresa Dias, Marisa Balthasar, cujas trocas durante os cursos foram de grande auxílio na concatenação das idéias voltadas para a pesquisa que planejávamos executar. Também a Nivia Marcelo, nossa gratidão.

A Luiz Mattos, o porto seguro de todos os pós-graduandos do Departamento de Teoria Literária e Literatura Comparada, da Faculdade de Filosofia, Letras e Ciências Humanas da Universidade de São Paulo, pelas inúmeras vezes em que orientou com presteza e simpatia acerca dos detalhes burocráticos para o bom andamento do projeto.

A Bruno Marquart, cuja visão de editor e publicitário, além de amante da literatura, contribuiu em muito na leitura crítica e formal desse trabalho.

A Bruno Kemmer, que sempre demonstrou genuíno interesse pelos progressos da pesquisa e nunca economizou palavras de ânimo.

Aos demais parentes e amigos, que de uma forma ou outra contribuíram para este trabalho. 
RESUM 0

Em 0 fiel e a pedra, Osman Lins compõe seu romance sob a égide do romance regionalista brasileiro produzido por volta de 1930: latifúndio, exploração de classes, jagunços e coronéis e outros males. Todavia, mesmo ficcionalizando esses fatos sociais, o autor pernambucano se distancia de uma possível rotulagem normativa inconteste ao aliar seu romance às epopéias clássicas, bem como à poética sacro-hebraica e também às cantigas populares nacionais, encetando um grande diálogo entre seu romance e Ilíada, Odisséia, Geórgicas, Eneida, Os lusíadas, Sermão do Mandato, salmo bíblico e canções populares. Cruzam-se, desse modo, diferentes vozes poéticas advindas de variados espaços e trazidas de eras díspares entre si por considerável gama de citações em epígrafe, as quais, por si só, já despertam instigantes inquirições e expõem, mesmo que subliminarmente, o ideário do autor pernambucano. 0 dialogismo e a polifonia pressupostos por Bakhtin acham-se contemplados nesse portentoso intercâmbio de textos que tem o mérito de, dentre outros aspectos, nos auxiliar a melhor entender o romance osmaniano de 1961. Através das citações, percebemos a incorporação de conceitos epopéicos greco-romanos de caráter e destino sendo tomados de empréstimo à trajetória do protagonista nordestino, introduzindo na personagem o perfil heróico que a notabiliza.

Palavras-chave: Osman Lins, 0 fiel e a pedra, literatura, Bakthin, dialogismo, polifonia. 


\section{ABSTRACT}

In $O$ fiel e a pedra, Osman Lins composes his novel under the aegis of the Brazilian regional romanticism produced around the 1930's: latifundium, class exploration, vigilantes, colonel farmers, and other wrongdoings. However, even if we fictionalize these social events, the Pernambucan writer keeps a distance from a possible unchallenging normative labeling by aligning his romance to classical epics as well as to the sacred-Hebrew poetry and national popular chants. With this, the author started a great dialogue between his romance and Iliad, Odyssey, Eneida, Lusiadas, Georgics, Sermão do Mandato, the Bible Psalms, and popular chants. Thus, different poetical voices from varied spaces are interwoven and brought from distinct ages by a considerable range of citations in epigraph. These citations themselves arise stimulating scrutiny and expose, even subliminally, the ideas of the Brazilian author. Bakthin's dialogism and polyphony are contemplated in this vast textual interrelation which is able to help us understand the 1961's Osmanian romance. Through citations, we can notice the incorporation of Greek-Roman epic concepts of character and destiny being borrowed by the Brazilian Northeastern protagonist, introducing the historical profile in the character that distinguishes him.

Key-words: Osman Lins, O fiel e a pedra, literature, Bakthin, dialogism, polyphony 
SUMÁRIO

Introdução - p. 1

Parte I - Caráter, p. 7

Parte II - Vozes, p. 92

Parte III - Destino, p. 121

Conclusão, p. 193

Bibliografia, p. 208

Notas de fim de texto, p. 221 


\section{INTRODUÇÃO}

Abre a narrativa de $O$ fiel e a pedra o anônimo cantor das feiras e praças do povo. O trovador nordestino entoa: "Agora conto a história / de um macho de coragem,

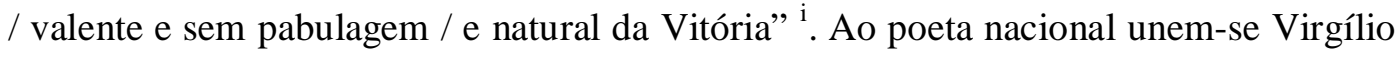
e Camões. No interior do romance ainda nos depararemos com Homero, Vieira e o bíblico rei Davi, todos anunciando, com sua poesia profética e epigráfica ${ }^{\mathrm{ii}}$, o que leremos no interior da história de dois jovens pobres do interior do Pernambuco de 1936. Não há como se quedar indiferente ao poder dessas vozes resgatadas de tão distantes eras e dos mais variados baús, belas palavras que se infiltram na prosa de Osman Lins, tão revestida de pendor lírico. Difícil é se quedar impassível ante a tessitura poética daí resultante, aliada à excelência da linguagem - aliança de rigor de pensamento e ousada imaginação - sobretudo a adequação de vocábulos que transmitem explosão de sonoridade, luz e sombras, cheiros - enfim, descrevem em detalhes, a ambientação das cenas do romance. Osman Lins consegue o extraordinário feito de nos inserir no espaço da narrativa, quase nos obrigando a sentir os cheiros; a ver, efetivamente, as paisagens; a ouvir as tantas canções que se erguem no ar como mensagens do vento e alcançam os ouvidos das personagens. Para o olhar não se perder ou divagar por entre a profusão de recursos criativos, escolhemos enfocar um aspecto que se mostrou, por sua vez, também plurifacetário: a implicação das citações emprestadas e tão bem amalgamadas nesse romance osmaniano de 1961. Quando da publicação de O fiel e a pedra, crítica e público comum, perceberam o liame indefinível entre texto e textos como gerador de certa doce estranheza. Tentavam empregar imagens, algumas hiperbólicas, para a definição da receptividade da obra. Um articulista comparou sua própria reação ao ler o livro como um "soco na cara" iii. O fiel e a pedra foi considerado a Eneida brasileira, buscando outra analogia, Bernardo virou o Dom 
Quixote nacional, o humilde Antônio teve sua função exacerbada ${ }^{\text {iv }}$, enfim, cada qual procurando representar imageticamente sua co-leitura participativa. A grandiosidade do arcabouço do romance atraiu possibilidades interpretativas. O projeto de escritura demonstrou-se, por si só, um arquitetado edifício: o autor nordestino conseguiu misturar à veneração inconteste pelo tio os textos fundadores da literatura ocidental. Ainda obteve êxito na façanha de mostrar problemas humanos, tintos com a cor nacional da época, às indagações filosóficas que o homem se faz desde que é homem. Surgiu então, um produto que não se enquadra na literatura de denúncia, tão vigente nos anos 1930 ou em formulações convencionais da literatura comparada. Sobretudo, o que se vê na obra é uma fusão de imagens, cujo teor apresenta-se um tanto irrotulável. Bernardo é Aquiles, é Odisseu, é Enéias e não é nenhum desses heróis. Em seu estopo correm partes de um, de outro, mas não podemos deixar de ver no protagonista o brasileiro, o nordestino, enfim, o homem de Vitória de Santo Antão. Quase nada se clarifica nesse romance de Osman, como não se esclarece cabalmente o ser humano. Não há respostas prontas. O certo é que ao estudioso ou leitor comum algo se mostra intensamente em $O$ fiel e a pedra - algo que muito agrada, mesmo não se sabendo exatamente por quê. Mas, talvez a grande idéia observada por quase todos é a de que o romance parece ligarse ao regionalismo, porém, dele foge paradoxalmente, conectando-se em linha direta aos primórdios da literatura. O romance, escrito em 1960, mas tendo como tempo literário o ano de 1936, apesar de aparentemente calcado nos moldes regionalistas (ficcional e tangencialmente abordando feridas características do Nordeste do Brasil: latifúndios, exploração de empregados e outras mazelas) empreende, ao mesmo tempo, esse amplo diálogo literário rompendo as barreiras de espaço, tempo ou gêneros. Instigante é notar que ao recolher fragmentos desses poemas exteriores e inseri-los em seu romance o autor monta uma espécie de corrente ligada a textos religiosos gregos e hebraicos. Os 
elos são seqüenciais, um texto herdando cores do antecessor - a ele remetendo e por ele subsistindo: Odisséia se remete à Ilíada, Geórgicas e Eneida a ambas e Os lusíadas, a todas. No caso de Vieira, o sermão se reporta a um texto da Bíblia, que também é citada no romance de Osman. Além dessa óbvia apropriação dos textos poéticos grecoromanos, hebraicos e populares, evidenciadas nas citações, o escritor submerge o conteúdo do romance nesses textos fundadores. Depois, ao reescrever $O$ fiel e a pedra em sua feição definitiva, escolhe a Eneida para o modelo preponderante ${ }^{v}$.

Sabemos que Virgílio era sobremaneira versado nos filósofos e artistas gregos e latinos. Platão, Aristóteles, Empédocles, Epicuro, Homero, Píndaro, Ésquilo, Sófocles, Fídias, Praxíteles, Varão, Catão, Ênio, Lucrécio, Catulo estão presentes em sua obra alguns, os contemporâneos, tendo sido amigos íntimos ${ }^{\mathrm{vi}}$. Ao escrever Eneida, Virgílio, tão impregnado dos ideais nacionalistas de Augusto, apropriou-se de temas e personagens das epopéias de Homero (particularmente da figura lendária do herói troiano, Enéias) e produziu uma bela e inusitada obra que adentrou para a História por sua sensibilidade ${ }^{\mathrm{vii}}$. As razões para a escolha do trajeto literário de Eneida, além dos ideais de Augusto, estavam em dois pontos: no caráter do protagonista da aventura de refundação do reino itálico e também no destino que lhe dirigia os passos. Dessa maneira, o poeta mantuano se entrega à tarefa de compor a personagem máxima para a sua epopéia: ele seria um misto de Aquiles e Odisseu (mostrar-se-ia irado e agressivo, no sentido das conquistas, e, astuto, curioso, empreendedor e também sofredor); sua epopéia teria incorporada a Ilíada e a Odisséia. Da primeira, as batalhas, da segunda, o caráter do herói navegante. Odisseu foi considerado por estudiosos o mais bem-quisto dos heróis homéricos, era uma espécie de espelho do homem grego livre ${ }^{\text {viii }}$. Por fim, Virgílio optou em iniciar seu poema pela alusão direta à Odisséia, deixando para as alusões mais diretas à Ilíada a segunda parte de sua produção literária. Eneida, sabemos, 
inicia-se com as viagens de Enéias e encerra-se com as batalhas contra Turno e os seus parceiros. Continuando na esteira de Virgílio, Camões, outro célebre escritor de portentosa formação intelectual, enceta um amplo diálogo com textos anteriores ${ }^{\mathrm{ix}}$ ao se voltar para os heróis gregos e latinos, na busca de seus modelos de personagem. O herói grego, depois revisitado no romano, encarnaria uma visão de mundo e a representaria. Já dizia Aristóteles: "Homero, por exemplo, imitava pessoas superiores" x. E a fascinação pelos admirados e imitados gregos é comentada por Lukács:

"Belas almas buscam os seus próprios instantes sublimes, instantes fugazmente efêmeros, nunca apreensíveis, de uma sonhada tranqüilidade por trás dessas máscaras taciturnas, caladas para sempre, esquecendo que o valor desses instantes é a sua fugacidade, que aquilo de que fogem para buscar abrigo junto aos gregos é a sua própria profundidade e grandeza. Espíritos mais profundos, empenhados em coagular em aço purpúreo o sangue que lhes brota e forjá-lo em couraça, para que suas feridas permaneçam eternamente ocultas e seus gestos de heroísmo tornem-se o paradigma do verdadeiro e futuro heroísmo, a fim de que o novo heroísmo seja por ele desperto, comparam a fragmentaridade de sua figuração com a harmonia grega, e os próprios sofrimentos, de que brotaram suas formas, com os sonhados martírios que precisaram da pureza grega para ser pacificados" (LUKÁCS: 2000, 27-8).

Corroborando o comentário de Lukács, desde as muitas leituras do seu tempo de solitária e introspectiva criança ${ }^{\mathrm{xi}}$, Osman Lins encanta-se com os heróis clássicos, além de muitos outros protagonistas de histórias marcantes dos grandes livros, influenciandose, também, pela performance dos mocinhos dos filmes de cowboys ${ }^{\text {xii }}$ (outra fascinação do menino Osman), o viés heróico indiscutivelmente penetrado na representação. Depois de escrever $O$ visitante $e^{x i i}$, decide encetar outro romance, dessa vez, contando de sua infância. Sobre o código heróico, tão intensamente exposto em Ilíada e Odisséia e imitado criativamente na Eneida, por sua vez, inspiradora de Os lusíadas ${ }^{\text {xiv }}$, bem como nos descendentes dos heróis dessas epopéias é que o autor cinzela o perfil do protagonista de seu romance. O romance de 1961, então, será um produto das muitas 
leituras feitas dos discursos do tio - as narrativas orais; dos textos verbais aliados às imagens - a arte filmográfica; as narrativas escritas na forma de canções épicas ou inseridas na canção popular; as belas histórias bíblicas ou imersas nos sermões ${ }^{\mathrm{xv}}$. Ao escritor pernambucano ocorreu ousar nas adoções textuais sem receio de anacronismo e um olhar admirado para o grande projeto de Osman foi o que moveu nossas intenções e métodos. Por isso, no estudo de $O$ fiel e a pedra, aventuramo-nos no mesmo caminho: encontrar Aquiles nas pegadas de Bernardo ou Bernardo nas pegadas de Aquiles - o mesmo se dando com Odisseu e Enéias. Com a finalidade de melhor entender o texto osmaniano, optamos por não nos restringir a uma visada imanente, e levamos em conta aspectos histórico-sociais e até biográficos mesmo que nem todas essas vertentes estejam devidamente contempladas no decorrer da leitura. Foi necessário, de outra forma, um mergulho nos deliciosos, mas complexos, textos greco-romanos de Homero e Virgílio. Evidentemente que, para uma proveitosa reflexão desses belos poemas, houve a necessidade de horas de leitura de comentadores, cada um na sua especificidade, muitas vezes, um citando o outro ou contradizendo-lhe. Quanto às bases teóricas de nossas reflexões, essas se fundaram sobre os postulados de Bakhtin ${ }^{\text {xvi }}$, mesmo que o russo tenha laborado no pensar de seus precursores que abordaram o trânsito entre literaturas, como Saussure, Tinianov, Chklovski, Mukarovsky e outros ${ }^{\text {xvii }}$. Na concepção de $O$ fiel e a pedra, o autor rejeita o caráter monológico do romance tradicional e se arrisca no plano polifônico, o que será sua marca nas obras seguintes. O dialogismo e a polifonia observados por Bakhtin no romance de Dostoievski serão ferramentas bemvindas em nossa análise, pois entendemos que Osman Lins ${ }^{\text {xviii }}$, em $O$ fiel e a pedra, também retoma os textos anteriores citados e os discute através das personagens, seja no caráter das mesmas ou em seus discursos, seja nas atrativas palavras tomadas de empréstimo. As considerações de Bakhtin serão uma espécie de guia-mór que, no 
entanto, em nossa reflexão, se deixa auxiliar por bem-vindos co-pilotos. O caminho, portanto, foi escolhido e palmilhado em um consórcio produtivo, embora não unânime e convergente o tempo todo. Empregamos vez ou outra, (sem explicitação, já que amplamente conhecidos) termos como dialogismo e polifonia (e as sub-categorias, propostas do dialogismo por Bakhtin ${ }^{\mathrm{xix}}$ como discurso bivocal, paródia, paráfrase); intertextualidade $^{\mathrm{xx}}$, de Kristeva, cujas contribuições na reflexão sobre os postulados de Bakhtin são inegavelmente relevantes, além de outros termos mais recentes e genéricos, como empréstimo, apropriação, atualização e outros ${ }^{\mathrm{xxi}}$.

Esperamos que esta análise do romance $O$ fiel e a pedra, cujo enfoque é, reiteramos, o grande diálogo que enceta com poemas ancestrais, propicie certa contribuição para os estudos de nossa literatura. Por um lado, para a observação de um quadro social registrado no interior da criação literária, segundo a capacidade ficcional da literatura de registrar os fatos sociais como conteúdo e, em ponto de vista complementar, segundo o poder das construções sociais modelarem as criações da linguagem. Por outro lado, para a observação do ousado projeto do autor - o entretecimento com obras de tão variado perfil afigurando-se a um esboço criativo que deu certo. Por fim, cabe ressaltar que muito há ainda em $O$ fiel a pedra a ser explorado, seja no quesito das citações, seja em quaisquer outros aspectos. Mas, aviso aos navegantes desprevenidos: o perigo das sereias cantantes é grande! Elas, como na Odisséia, cantam a história do herói, mas podem levar o estudioso a se apaixonar pela cantiga - a história do próprio homem - e mergulhar a fundo no mar das belas palavras, sem desejar retornar à tona. Cera e corda devem estar preparadas! 


\section{PARTE I - CARÁTER}

Olhando para o belo conjunto de citações tomadas de empréstimo a poemas de origem diversa, desde o anônimo letrista de uma canção dos modernos trovadores nordestinos até Homero, Virgílio e Camões, inferimos que o autor de $O$ fiel e a pedra desejou estabelecer sua linhagem com a poética anterior, não apenas a (hoje) reputada clássica, ${ }^{\text {xii }}$ mas a popular. E diante dos primeiros versos citados ("Agora conto a história / de um macho de coragem...), sabemos que dessa poética emprestada, a figura do herói ganha destaque. Ao lermos a segunda epígrafe, entenderemos que esse herói adveio de dura vida: "Impôs a Natureza a lugares certos estas leis e estas imutáveis condições, imediatamente depois que Deucalião, pelo orbe vazio, esparziu pedras, donde nasceram os homens, raça dura” xiii. Sem a leitura de um parágrafo sequer, já podemos concluir que o protagonista de $O$ fiel e a pedra foi ideado tendo os heróis como seu grande modelo - o valente e de raça dura. E tal arcabouço nos remete às grandes personagens das epopéias citadas ao longo do romance: Ilíada, Odisséia e Eneida. O caráter dos heróis desses poemas épicos sustenta, em parte, a riqueza da narrativa $^{\mathrm{xxiv}}$, e é sobre tais figuras que estenderemos o olhar, a fim de entendermos essa feliz aproximação. Deixaremos de lado apenas o herói coletivo de Os lusíadas, epopéia também citada em epígrafe de $O$ fiel e a pedra, exatamente pelo projeto ousado e criativo de Camões, forjando um herói diferente que se afasta da figura individual e aguerrida dos demais. O herói épico, recordemo-nos, era um semideus dotado de qualidades superiores aos demais: coragem, valentia, força, generosidade e assim por diante, como o comenta Finley:

“'Guerreiro' e 'herói' são sinônimos, e uma cultura guerreira organiza-se à volta destes dois temas fundamentais: a coragem e a honra. A coragem é a virtude essencial do herói, a honra o seu objetivo essencial. 
Toda a norma, todo o juízo e toda a ação, todas as aptidões e talentos têm por função definir a honra, ou seja, realizá-la" xxv .

Embutidas no conceito de honra estão virtudes diversas como coragem, valentia, intrepidez, senso de justiça, bondade, piedade (devoção aos deuses, pátria e família) e outras. Vamos analisar algumas dessas virtudes que os heróis apresentam em seu caráter e que Bernardo também manifesta.

\section{Valentia}

Aquiles, sabemos, era conhecido por seu ímpeto belicoso, diligência na guerra e capacidade física extraordinária. O epíteto pés-velozes ${ }^{x x v i}$ [ou os correlatos pés-rápidos e pés vigorosos] aparece cerca de quarenta vezes no poema e faz referência à incrível velocidade do jovem nas corridas - aptidão aliada à potência muscular e excelente condicionamento físico, atributos necessários nas guerras antigas, cujos participantes permaneciam, às vezes, o dia inteiro nas lutas corporais. Também comparecem, da mesma forma qualitativa, os vocábulos ou expressões ligados à valentia, por exemplo. Ao narrar a Mákhe parapotámos - Batalha à beira-rio, Homero insere nas palavras do Escamandro elogios ao grande guerreiro aqueu. $\mathrm{O}$ rio antropomorfizado elogia o guerreiro: "Aquiles, o mais forte, o magno / fazedor de malfeitos entre os homens" (Il, XXI, 214-5) e depois acrescentará: “(...) Aquiles, famoso na lança” (Il, XXI, 233). No canto que trata do torneio em tributo a Pátroclo, ao se referir a Aquiles, o narrador segue na mesma linha qualitativa: “(...) o provoca pavor, Aquiles, o mata-homens” (Il, XXIII, 17). Em Ira, Mênis, amaina, o cavalo de Aquiles, o antropomorfizado cavalo, Xanto, chamará seu dono "impetuoso Aquiles" (Il, XIX, 408). Prosseguem dessa maneira os epítetos ligados à valentia de Aquiles famoso na lança; rompe-tropas; rompeesquadrões; temível Aquileu; furioso; mortífero; fogoso; Peleide insaciável de 
guerra $^{\text {xxvii }}$ e outros epítetos relacionados à atuação audaz, agressiva e influenciadora na guerra: o mais forte, o magno fazedor de malfeitos entre os homens; forte; o mais forte dos Aqueus; fortíssimo; fulgurante; ícone aquilino; [comandante] pastor-de-povos; entre os Aqueus o mais forte em toda a armada; grande-de-ânimo; ânimo-grande; meganimoso; sobre-animoso; formidável; gigânteo; ilustre; bravíssimo herói, honra dos deuses.

Odisseu também não fica atrás no quesito - é reconhecido como um guerreiro audaz, notável pela experiência de guerra e valentia nas empreitadas bélicas. $\mathrm{Na}$ Odisséia ${ }^{\text {xxviii }}$, além dos epítetos ligados à sabedoria, habilidades lógicas e astúcia, o guerreiro grego também é chamado de audacioso, experiente, famoso, de alta fama, glorioso, grande, valoroso (Od, I, 207; II, 238; XV, 347; XVII, 314; XXIV, 541).

Enéias $^{\text {xxix }}$, além de piedoso, é também chamado valoroso (uma vez, apenas), fatal, indígite; o que se torna visível o quanto a personagem se afasta de seu perfil iliádico $^{x x x}$. Essa dicotomia se dá, em parte, pelo caráter mais delicado e não tanto violento como o troiano de Ilíada e também pela diferença de estilo entre Homero e Virgílio. No entanto, não se pode dizer que Enéias não se apresente valoroso e ousado em Eneida. Há certa ênfase nesse aspecto, o que uma ou outra frase testemunha, como por exemplo, o que dele dizem os companheiros: "Rei nosso Enéias é, que a ninguém cede, / (...) valente e belicoso (...) $"(E n$, I, 571-3).

E como se nos mostra a valentia no caráter do herói em $O$ fiel e a pedra? O macho de coragem, valente e sem pabulagem já se mostra no primeiro capítulo do livro, que dá conta de uma cena - assim é como o narrador qualifica o triste momento da morte de uma criança, tendo seus pais como únicas testemunhas, mudas e impotentes. $\mathrm{O}$ pequeno José falecera de uma enfermidade não explicitada no romance, mas (isto o sabemos), não tratada de forma médico-profissional, em virtude da exigüidade de 
recursos da família. O pai, Bernardo, demitira-se do emprego em um posto fiscal que avaliava as cargas transportadas. O motivo da saída do trabalho fora a corrupção da parte do responsável pelo lugar. Sentindo que se permanecesse no trabalho estava se fazendo cúmplice da desonestidade, Bernardo levara seus princípios ao auge e optara pelo afastamento do ambiente promíscuo. Levado pelo dever arraigado na consciência, tão à moda do imperativo categórico kantiano ${ }^{\text {xxxi }}$, Bernardo não se dobrara ao que considerava imoral. Bernardo refletia se agira corretamente e conclui que faria tudo igual caso o problema se repetisse. Para a mulher, justificara: "- Mesmo agora, se tivesse que decidir, eu fazia o mesmo. Apesar de tudo, fazia de novo o que fiz. Esse prefeito agora é um ladrão, Teresa. Eu posso ter errado, mas não estava em mim continuar. Outro qualquer ficava, lavava as mãos.” (OFP, 4). O elevado senso moral provocara reação negativa nos concidadãos. Um a um os possíveis empregadores lhe negaram qualquer tipo de ajuda, seja na forma de um novo emprego, seja nos empréstimos solicitados. Posteriormente Bernardo saberá através de Miguel Benício (rico empresário de secos e olhados da cidade e também fazendeiro), de que o boicote fora tramado deliberadamente com a intenção de puni-lo. As hostes poderosas de Vitória condenavam o caráter do funcionário corrupto - o novo fiscal -, mas não tinham a coragem de se oporem a ele e, como cordeiros acéfalos, capitulavam aos desmandos do agente público. Por conseqüência, passaram a detestar a única pessoa que, sozinha, ousara erguer a bandeira da moralidade (mesmo que tal agente estivesse sem inteira consciência da grandeza de seu ato). Ao recusar um enriquecimento ilícito em conluio com os demais actantes da improbidade, Bernardo rompera a cadeia do mal, desafiando, inclusive, as circunstâncias futuras e nada alvissareiras:

"Você fez como poucos, entende? Você a bem dizer, não era nada; e mandou para o diabo segurança e acomodação. Muita gente graúda, de arca 
abarrotada, era contra Coutinho e já está com ele. (...) É por isso que lhe odeiam e têm inveja. (...) E pode ficar certo: por enquanto, você não tem oportunidade aqui. Eles têm de provar, esse pessoal de Vitória, que você está errado. Querem ver seu castigo, sua queda. (...)" (OFP, 30).

O próprio Miguel criticara Bernardo, considerando o pedido de demissão do emprego como o resultado de um lampejo momentâneo de rebeldia: “- O que você fez foi estúpido. Não se deve fazer nada precipitadamente. Largar um emprego por capricho!" (OFP, 29). Miguel dissera, em outras palavras, que Bernardo não deveria ter se importado tanto com os desvios de conduta, pois o patrimônio lapidado não tinha um “dono” - pertencia à coletividade: “- O Posto Fiscal não é propriedade de Agripa Coutinho. Não é propriedade do Prefeito" (OFP, 30). A racionalidade defendida pelo fazendeiro era das que buscavam os próprios interesses acima de tudo, o que não sucedia com Bernardo. Ele respondera dizendo que agira racionalmente: “- Não foi por capricho. Nem foi por precipitação" (idem). Enfim, Bernardo não buscara seus próprios interesses, mas os de sua cidade. Miguel Benício penaliza-se ante a situação de Bernardo (desemprego e total ausência de recursos), embora admita haver se indignado, tanto quanto os demais "senhores" de Vitória, ao saber da famosa demissão. Mesmo interpretando o ato do jovem como prova de arrogância, acenava-lhe ainda com a hipótese de sociedade na criação de gado. Surge, a partir daí, uma parceria que parece fadada ao sucesso: Miguel oferece um emprego a Bernardo - a função de barraqueiro na fazenda onde outrora existira um ativo engenho de cana. O jovem esposo de Teresa iria administrar as vendas do barracão, o pequeno empório rural, bem como, esperava Miguel, cuidar dos demais funcionários do local, efetuar pagamentos, plantio, compras. Benício oferecia de outra forma, sociedade na criação de gado. A coragem (ousadia, valentia) de Bernardo desperta a admiração em Miguel (ou pelo menos a amplifica) a ponto de instigá-lo a se unir àquele jovem ousado e desafiador. Essa ousadia se manifesta em outra circunstância, essa nada alentadora. Chega o dia em que Bernardo 
passa pela tristeza de contemplar o corpo sem vida do patrão e amigo, vítima de uma queda da escadaria de seu armazém. O esposo de Teresa suspeita que a morte tenha sido provocada por um terceiro, aliás, por um terceiro específico: o irmão do morto; afinal, intuíra desde o início o ódio latente acalentando por Nestor em relação ao irmão mais velho. Segundo o que percebera Bernardo, Miguel tinha ciência do corrosivo sentimento e tentava relevar e acalmar situações de conflito, como o boato de que o mano teria importunado sua mulher. Segundo os comentários ferinos de outra personagem, Suzana, por ocasião de os vizinhos terem presenciado Nestor deixar a casa de Creusa e Miguel com o queixo sangrando, em vez de cortar relações com Nestor, o suposto esposo traído teria estendido a mão ao provável rival e o beneficiado financeiramente. Enfim, Bernardo pressentira um potencial explosivo no sentimento nada fraternal do protegido em direção ao seu protetor. É com base nessas premissas subjetivas que surge a conclusão acerca da morte repentina de Miguel. No entanto, seria mister muita coragem para alguém erguer a voz em público e verbalizar a suspeita: Nestor fazia parte dos mandantes de Vitória, daqueles que resolviam os negócios tendo como base os meandros moralmente nada saudáveis da cooptação desonesta. Haja vista o fato de haver oferecido dinheiro com a finalidade de o tabelião apressar a falsa compra dos bens de Miguel - a transferência forjada de parte dos bens a fim de que, por ocasião do divórcio premeditado às ocultas, Miguel pudesse sair lucrando na partilha do patrimônio do casal -, a mesma negociata ilícita que o patrão propusera a Bernardo e esse se negara a concretizar (um ato de valentia, também). Vendo o corpo de Miguel estendido no piso frio do armazém, Bernardo ousa pronunciar seu veredicto: “- Isso foi crime. (...) Ninguém me tira da cabeça que isso foi crime." (OFP, 95) A reação dos presentes, delegado, soldados, curiosos e o próprio Nestor, é de raiva: "Sentiu, em torno de si, olhares irascivos." (OFP, 95). Depois, surgem comentários zombeteiros acerca do 
provável modus operandi do suposto assassino e Bernardo tem, novamente, a coragem de censurar, veementemente, a todos: “- Que risadas são essas? - gritou. Não estão vendo um homem morto?" (OFP, 95). Nestor percebe a suspeita de Bernardo voltada contra ele e mais adiante tratará de se justificar, sem muito êxito. Os leitores nunca alcançarão a verdade sobre a autoria do crime (ou se houve, efetivamente, um crime); todavia, restará para nós, os leitores, a admiração pela ousadia de um rapaz simples em tentar convencer as pessoas a analisar a morte de Miguel sob novos ângulos - o que não se dá, evidentemente. Enterrado o amigo e benfeitor, Bernardo continua no engenho do Surrão, seguindo sua vida. Logo recebe a visita de Nestor que tenta dissuadi-lo da desconfiança em relação a sua pessoa, oferecendo grandes benesses em troca de apoio incondicional a tudo o que intentava realizar. Um desses objetivos é levar o gado da fazenda para outro lugar, a fim de que a cunhada dele não se apoderasse. O pretexto é laborar em prol dos sobrinhos, pois a mãe poderia prejudicá-los. Bernardo ouve as sedutoras e excessivas palavras de Nestor e quase cede às intenções do mesmo. Afinal, seria fácil compactuar com a vontade do novo patrão, mesmo que houvesse dúvida quanto à probidade do caso - ele, Bernardo, não teria envolvimento direto com o erro era um simples empregado de mãos limpas. Caso apoiasse Nestor na decisão de levar os animais, resguardaria o emprego, teria a tranqüilidade garantida para continuar comprando e criando gado - tudo muito tímido, mas com certeza de prosperidade: “Acalmou-o a reflexão complacente” (OFP, 105). E então outro episódio da infância é rememorado. Ao pedir a freqüentemente negada permissão para tomar banho no rio, o protagonista beijara a mãe numa expressão afetiva não usual entre ambos. Lucinda anuíra ao pedido e Bernardo correra para o rio, para divertir-se nas brincadeiras infantis. Contudo, o gesto, aparentemente simples, de beijar a mãe não lhe saía da mente. Enquanto os outros garotos se entregavam à saudável recreação, ele se remoia em 
dúvidas, efetuando uma rigorosa varredura em suas reais intenções ao efetuar o gesto amoroso. Teria demonstrado o carinho apenas para auferir êxito no que reivindicava? A incerteza quanto à pertinência do gesto - banal para outras crianças, mas estranho para ele - esmagara a satisfação dos momentos recreativos: “(...) aqueles beijos, dera-os para que Lucinda consentisse?” (OFP, 106). Aliada à coragem e capacidade para enfrentar os desafios encontra-se a noção embrionária de ética (palavra desconhecida para o menino, evidentemente) não lhe dava o direito de usar as pessoas para conseguir realizar seus intentos. Enfim, a angústia de perceber sua atitude desmascarada pela própria consciência ${ }^{x x x i i}$ o obrigara a retornar para casa: "Mergulhara os pés descalços, voltara (...)" (OFP, 106). Enfrentando-se a si mesmo nas atitudes mínimas, porém, contrárias ao seu padrão do que era correto, o menino Bernardo construíra o caráter. Afinal, era preciso ter coragem para encarar seus próprios defeitos e lutar para eliminá-los, o que se cristalizou, a partir de então, na guerra diária da qual nunca Bernardo nunca se libertaria: "Como entender e dominar os seus abalos, seus impulsos, até que ponto era justa sua maneira de agir, onde começavam os seus erros?” (OFP, 199). A lembrança do episódio do beijo - a consciência servindo como implacável juíza - liga-se à reação muda, mas acusatória, de Teresa ao ouvir as justificativas de Bernardo para a anuência com os planos de Nestor com relação ao gado de Creusa e herdeiros. Veja-se como o narrador descreve o passo: "Falara a Teresa, pouco antes, da conversa com Nestor Benício. E sentira, no seu silêncio, uma sombra de censura. Injusta, porém: nada podia fazer" (OFP, 104). No silêncio da mulher, tantas palavras de exprobração! Tudo leva Bernardo a cristalizar a decisão de opor-se à retirada do gado. E a conclusão pressupõe muita valentia, ao que se verá na obra, cujo autor desenhara o perfil de Nestor como o de um "coronel" nordestino, arbitrário e corrupto. E tal se dá. Instaura-se a hostilidade que originará o restante do amargo e duradouro conflito. Quando Nestor vier para 
buscar o gado, Bernardo anunciará sua resolução de não permitir que tal aconteça. $\mathrm{O}$ narrador apresentará a situação mais ou menos como num filme de cowboys (gênero apreciado grandemente pelo menino Osman Lins e que seria rememorado ficcionalmente na obra literária como um todo). A seguir, oferecemos as palavras do texto osmaniano a fim de se comprovar o clima da cena (palavra utilizada pelo narrador): o grupo banhado pela luz das estrelas, a agressividade estampada nos gestos, a autoridade vislumbrada na indumentária de Nestor:

"À luz das estrelas, o pequeno grupo aguardava-o, Nestor Benício à frente; trazia uma chibata, esporas, botas de cano alto. De cada lado, como a protegê-lo, estavam Precipício e Xenofonte. (...) À esquerda, um pouco recuado e trazendo uma vara, balançava-se um sujeito alto, mentiroso, que chegara no Engenho dias antes; falava com Tiago, que empunhava um cacete e ficara de costas para a cena, como se nada tivesse a ver com o que se passava. Mas Bernardo sabia que sob o chapéu desabado, um olho mau do negro observava-o"(OFP, 109).

Efetivamente, diante do aparato intimidador, era preciso muita coragem para fazer valer a decisão de enfrentamento, como o fizera Bernardo, o qual, sem titubear, manifesta sua negativa quanto a concordar com a retirada dos animais: "- Estive analisando. O gado vai ficar aqui" (OFP, 109).

A valentia se mostrará ainda quanto a um dos capangas de Nestor, um sujeito mal-encarado e nada confiável. Diante da postura arrogante do outro, Bernardo não recuará: “'Mas eu não sou um covarde’ - pensou com amargor. E, novamente ansiou por circunstâncias que pusessem à prova sua coragem" (OFP, 113).

Em outro momento da narrativa, a ousadia enxertada pela ira e intrepidez, é percebida de forma acentuada, surpreendendo o próprio Bernardo. Trata-se do episódio envolvendo estranhos clientes que aparecem à noite, no estabelecimento comercial que Bernardo administrava no Surrão. Sob o pretexto de comprar alimento, o bando chegara amedrontando a família já pela maneira de bater à porta. Bernardo, corajosa ou 
imprudentemente, atendera aos visitantes: "Sua ira, a força de seu desafio, concentraraos no ato temerário, que lhe parecera indispensável e simples, de abrir a porta" (OFP, 184). Durante a visita dos desconhecidos, Bernardo se sente ofendido, pois o chefe do bando parece duvidar de sua honestidade. O fator desencadeante é um simples detalhe: um peso esquecido em um dos pratos da balança, objeto que, se não notado a tempo, afetaria o real aferimento do produto vendido. Ubaldo, o chefe do grupo, retira o peso, ostensivamente, incomodando o anfitrião que pergunta ousada e agressivamente: “- Que é que você pensa? Quem lhe deu autoridade pra ver se eu estou roubando? Você é besta?" (OFP, 185). Novamente estamos diante de um homem corajoso, uma vez que a situação tinha todos os contornos de uma ameaça velada da parte de Nestor. A valentia, entretanto, acha-se revestida de secreto temor que Bernardo atribui ser oriundo do medo que a esposa demonstrava nessa ocasião. Todavia, o que Bernardo expressa exteriormente é a audácia que se mostraria até as raias da tragédia, caso o chefe do grupo revidasse a injuriada questão.

Outro ponto em que a coragem se manifesta em Bernardo ocorre durante o retorno de uma visita a Vitória. No caminho, Bernardo ouve tiros em sua direção e o pavor o acomete. $\mathrm{O}$ viajante, contudo, segue seu trajeto, procurando refrear qualquer aparência de ansiedade e temor.

E por fim, ao enfrentar Nestor e os jagunços, durante o acerto final, Bernardo lança mão de muita força interior e coragem, porque as circunstâncias não lhe são absolutamente favoráveis. A valentia, nessa ocasião, apresenta-se dupla: ao rejeitar o preço exíguo que Nestor oferecera pelos parcos bens que lhe pertenciam (os bichos e a plantação de cará) e também ao controlar o desejo de descarregar sua arma, o parabellum, no peito do arrogante irmão de Miguel. 
No rosário de fatos elencados, constatamos, então, o quanto Bernardo se aproxima de Aquiles, Odisseu, Enéias, no quesito valentia (não nos esquecendo da preponderância do perfil de Aquiles nessa virtude).

Ira

Tendo Aquiles adentrado para a literatura ocidental como um sinônimo de valentia, intrepidez e coragem e havendo Osman Lins recortado, dentre as epopéias clássicas greco-latinas, um texto de Ilíada para mesclar-se à narrativa, veremos a aproximação que se pode efetuar entre Bernardo e esse grande guerreiro grego, em mais um ponto sobremodo particular: a complexidade do sentimento que move Bernardo, sentimento esse pautado pelo que no romance se lê como ira. Sim, Bernardo move-se impregnado de ira, como veremos, e a ira, como já se mostra no primeiro verso do poema, é a grande força motriz das ações de Ilíada. E lembremo-nos de que ira, no grego, pode indicar duas faces de um mesmo (ou quase) sentimento: ira, como furor explosivo que se manifesta intempestivamente, ou ira duradoura, um ressentimento prolongado. Aquiles apresenta ira sob dois ângulos primordiais - uma ira mais ativa, voltada para sua função nos combates, ira imiscuída à cólera, raiva, furor, demonstrando o quão ardoroso e sanguinolento o herói podia se mostrar na guerra, como os excertos a seguir exemplificam: Ao receber as armas das mãos de Tétis, veja-se a reação do guerreiro: "Mais se enfurece Aquiles, quando as vê. Seus olhos, / sob os cílios, fuzilam com feroz revérbero" (Il, XIX, 16-7). No embate contra Enéias, Aquiles se lança em fúria: "Contra ele se levanta Aquiles feito leão / predador (...)" (Il, XX, 164-5). No mesmo duelo, veja-se a incrível expressão de belicosidade: “(...) Mas / rompeu raivoso, rente dele, Aquiles, gládio / nu, ululando terrivelmente. (...)” (Il, XX, 285-6). A mesma palavra ira acontece nesse furor de guerra: / “(...) irado, disse ao coração / sobre- 
animoso (...)" (Il, XX, 344-5). No duelo contra Héctor, veja-se a ira do grego: "saltou, irado, mirando matá-lo, aos gritos, / medonho. (...)" (Il, XX, 441-3). O narrador descreve seu ímpeto aguerrido: “(...) quase-demônio, urrou palavras-asas, formidável: 'Cachorro, foges outra vez da morte. O azar / te rondou e passou perto. Febo salvou-te (...)" (Il, XX, 447-50). Outros exemplos há em Ilíada desse furor desproporcional e quase incontrolável e devastador de Aquiles ${ }^{\mathrm{xxxiii}}$. Por outro lado, o forte guerreiro aqueu cultuou também uma ira um tanto passiva [se é que assim podemos considerá-la, dado seu alto teor nocivo à comunidade...], que o afastou dos combates, uma ira duradoura, uma espécie de "prolongado amuo" ou ressentimento, por conta do ato de Agamenon em lhe tomar a cativa de guerra, Briseida. Essa ira de Aquiles é, na verdade, extremamente complexa, abarcando muitos sentimentos, fato que os estudiosos observam, dentre eles, Octavio Paz, de cujas idéias sobre o assunto, retiramos o excerto a seguir:

"Cada imagem - ou cada poema composto de imagens - contém muitos significados contrários ou díspares, aos quais abarca ou reconcilia sem suprimi-los. (...) O herói trágico, neste sentido, também é uma imagem. (...) A cólera de Aquiles tampouco é simples e nela se unem os contrários: o amor por Pátroclo e a piedade por Príamo, o fascínio ante uma morte gloriosa e o desejo de uma vida longa. (...) A imagem é cifra da condição humana" xxxiv.

Das muitas facetas da ira duradoura de Aquiles, destacamos algumas: senso de justiça, revolta, angústia, tristeza, obstinação, orgulho.

O senso de justiça manifesta-se, dentre outros exemplos, em certo momento da narrativa: antes de se entregar ao ímpeto violento, Aquiles se queixara da injustiça que o rei estava prestes a cometer ao anunciar que, em vista da perda de sua cativa, os guerreiros teriam que lhe dar alguma recompensa: 
"Ó glorioso Atreide, mais que todos ávido, que prêmio te hão de dar os Aqueus magnânimos?

Em parte alguma sei de espólio acumulado; o saque das cidades, nós já partilhamos.

Não é justo partir de novo o repartido"

(Il, I, 122-6).

Revolta, desejo de matar, intensa agressividade aliam-se a essa ira. Embora tentasse usar de lógica ao relembrar ao rei de que ele, Aquiles, estava ali apenas para auxiliar no projeto da família do atreide (combatia apenas para apoiar a causa de Menelau, dirigida pelo irmão), pois os aqueus nada tinham contra os troianos, o guerreiro deixa-se levar pelos impulsos e saca de sua espada para matar Agamenon, ao perceber que os argumentos racionais de nada estavam resolvendo:

“(...) No peito hirsuto do Peleide a angústia assoma. O coração, partido em dois, hesita. $\mathrm{Ou}$ arranca do flanco a espada pontiaguda e afastando os demais abate o Atreide no ato, ou reprime o furor, doma a revolta no ânimo. Tudo isso lhe rodava no íntimo e, entretanto, ia sacando da bainha o gládio enorme."

(Il, I, 188-94)

A tragédia é impedida por Palas Atena, que se agarra aos longos cabelos do herói e o impede de cometer o ato:

"Então, do céu, Atena desce. Enviou-a Hera, dos brancos cabelos, que ama os dois, por ambos vela. Por trás segura-lhe os cabelos louros, só visível para ele; ninguém mais a vê." (Il, I, 195-8)

Tristeza, angústia, melancolia mesclam-se à ira. Homero diz que a angústia toma conta do coração do jovem e fala da tristeza que vem imiscuída à ira: “(...) põe-se à parte, afasta-se, chorando, / sentado junto ao mar salino-cinza, e olhava / ao longe as águas cor de vinho. (...)" (Il, I, 349-51). 
Obstinação, inflexibilidade também se manifestam na recusa dos presentes de Agamenon, cujo fim era amenizar sua ira e obter a capitulação. Veja-se a resposta do grego: “(...). Odeio as dádivas / vindas de sua mão. Valem menos do que um pêlo.” (Il, IX, 374-9).

A ira de Aquiles é crescente, asfixiante. O poeta descreve a força do sentimento do guerreiro grego: “A ira o corroendo à beira de suas naves rápidas" (Il, I, 488). E por causa da atitude injusta de Agamenon, segundo Aquiles, esse se nega a lutar a favor dos aqueus, mostrando-nos qual o cerne de seu ressentimento - a honra (time), tão preciosa aos gregos: "Agora volto a Ftia. À casa, em naves curvas, / mais vale retornar, que imaginar-me aqui, / sem honra, a recolher-te espólios e tesouros” (Il, I, 169-71). Ao que tudo indica, porém, os vários sentimentos componentes da ira de Aquiles têm um único fundamento: o orgulho ferido em decorrência do sentimento de honra:

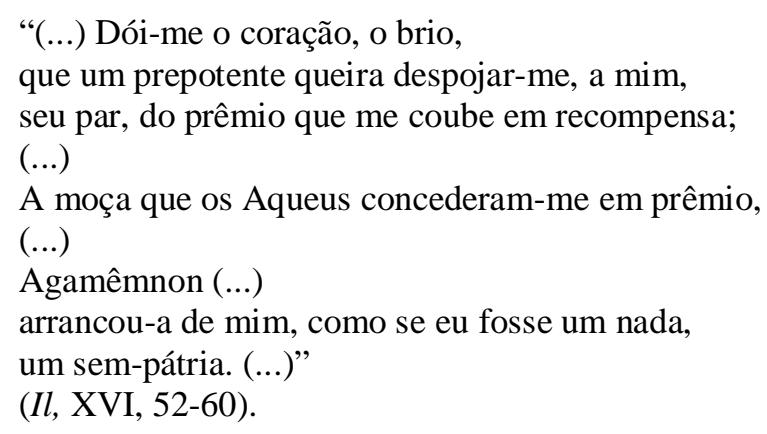

Segundo Aquiles, ao se apropriar da parte do espólio que lhe pertencia, o rei o considerava "um nada", "um sem-pátria", conceito antecipador do significado do outro nome de Odisseu, na epopéia que protagoniza: Ulisses - Ninguém. Extremamente ultrajado em sua honra, Aquiles dirá a Agamenon: “doa-te n’alma o ódio: ao melhor dos Aqueus / não honraste. (...)" (Il, I, 244-85). Ao receber a embaixada cujo objetivo era tentar dissuadi-lo da ira e novamente encaminhá-lo aos campos de batalha, Aquiles rejeita a proposta para, de novo, auxiliar o rei na guerra: 
“(...) Ajudá-lo? Eu?

Não coopero. Não dou conselho. Ele embrulhou-me,

é um malfeitor. Não vai enlear-me com palavras

de novo. Basta! Vai em paz! Sai, azar!"

(Il, IX, 374-7).

A ira de Bernardo apresenta-se dotada de múltiplos rostos - os quais, muito se afiguram à pluralidade que se mostra na ira do famoso grego: senso de justiça, revolta, angústia, tristeza, obstinação, orgulho ${ }^{\mathrm{xxxv}}$ e outros sentimentos. Analisemos alguns desses sentimentos.

Senso de justiça mostra-se intensamente na ira de Bernardo. Como no caso de Aquiles, clamando na assembléia por se sentir injustiçado, algo similar ocorre com Bernardo, sempre despertando ira em seu íntimo. Um exemplo dessa situação ocorre quando o protagonista corajosamente expressa discordância com relação ao pedido de Miguel Benício - a transferência de alguns bens imóveis para eliminá-los da partilha de divórcio. Miguel lhe perguntara se aceitaria "na qualidade de amigo, comprar-lhe algumas casas, transação fingida, válida somente no papel” (OFP, 70). Bernardo se negara, veementemente: "Sou capaz de fazer coisas mais difíceis. O senhor sabe disso. Mas essa, não é possível. Não posso" (OFP, 71). Mais tarde, já em casa, ficara irado por alguém haver-lhe feito tal proposta.

Isso que chamamos "senso de justiça" pode se mostrar no sentido de não fazer ao outro o que não desejaria que a ele lhe fosse feito e também na sensação de se perceber como alvo de injustiça provocada por outrem. Essa ira provocada pela sensação de estar sendo vítima de injustiça pode ser classificada com vocábulos de sentido aproximado, pelo narrador: palavras que lembram certa impotência diante do mais forte. Depois da morte de Miguel, Bernardo discordara dos atos espúrios de Nestor na questão do gado, por notar a injustiça do ato, e desde então, ganhara um inimigo. 
Nestor enviara carta exigindo o pagamento de aluguéis, algo nem sequer aventado no acordo com Miguel. Ao pedir para a esposa sugestão de como agir, e Teresa dizer-lhe que ele fizesse o que achava melhor, Bernardo demonstrará pelos olhos a ira ante a absurda cobrança de Nestor: “(...) os olhos azuis cheios de uma ira tensa e extática” (OFP, 143).

O senso de justiça pode despertar uma coragem até então desconhecida. E outro exemplo da ira mesclada ao senso de justiça e ousadia ocorre no encontro final, após o oferecimento, da parte de Nestor Benício, de um baixo preço para a roça de cará, em contraproposta ao preço pedido por Bernardo. O primeiro reclama: “- Você quer muito pela plantação, Bernardo. Perdeu a cabeça? A plantação foi estragada" (OFP, 300). E o barraqueiro se defende: “- Peço o que vale. Você só vai ter o trabalho de arrancar e vender". Após constrangedora insistência de Nestor, quanto à manutenção do preço que desejava dar para o cará, Bernardo diz: “- Assim você não quer comprar. Quer me roubar". O senso de justiça, portanto, clamando.

Bernardo também se questiona se ele havia sido justo ou não, em determinadas circunstâncias. No início da história, por exemplo, sabemos o quanto o jovem se questionava quanto a ter ou não agido certo ao atirar para o alto o ganha-pão - mais um ato da ira - mesmo que tedioso e incongruente o serviço se mostrasse aos seus padrões morais, principalmente, tendo em vista a necessidade de prover o sustento e os tratamentos médicos da família:

"Bernardo refletia: Agira erradamente? Era justa a atitude que assumira, tudo para obedecer a uma exigência íntima, convicção que ninguém - Teresa, sim - parecia entender? (...) Decerto que um dia, mais cedo ou mais tarde, ele abandonaria o emprego, onde se sentia um pouco desprezível, e onde tinha a certeza de que seu coração murchava, definhava aos poucos, como um preso. Sim, um dia entregaria o lugar. Mas não naquela hora, não assim. Seria tão simples condescender, deixar o tempo passar! E fora tão insensato o que fizera! Se bem executava o seu trabalho, importava-lhe o resto? O certo era contar devidamente, como sempre fizera, 
os volumes conduzidos pelos caminhões, cobrar o imposto devido, prestar as devidas contas. Que Agripa Coutinho e seu tesoureiro, e seus secretários, fossem todos ladrões, dizia-lhe respeito? Não era ele que roubava o dinheiro arrecadado. E no entanto, se continuasse...” (OFP, 2)

Revolta, desejo de matar, como em Aquiles, se mostram na ira de Bernardo. Como o grande guerreiro grego, que ao se sentir injustiçado vê a ira revestir-se de revolta, levando ao desejo de matar o adversário que o oprime, Bernardo, por sua vez, manifestara o desejo de matar o inimigo e, do pensamento, quase viera a prática: "Tocou o parabellum, fechou a mão sobre o cabo da arma, sopesou-a. Seria simples: o olhar atento, uma pressão no dedo, o braço decidido e forte. O importante era não ter compaixão, não hesitar" (OFP, 238).

Até o "coração dividido" de Aquiles é retomado em Bernardo: "E Bernardo ouviu dentro de si mesmo dois apelos, um que o fazia explodir, desafiar Nestor, lançarse contra os homens e outro que o incitava a humilhar-se, pedir que o poupassem" (OFP, 292).

Mais uma alusão ao coração dividido de Aquiles, surge em Bernardo cogitando dominar sua ira, abandonando a luta, afastando-se do lugar problemático em que se tornara o Surrão, visto estar sob a direção de Nestor que envenenara os moradores contra o esposo de Teresa: "Melhor ir embora quanto antes, tentar outra vida. Não ceder ao seu ódio, à sua desconfiança. Por que obstinar-se, teimar em fazer frente a um adversário mais forte (...)?” (OFP, 206).

E se Aquiles é impedido de cometer o assassinato pela deusa que o protege, Bernardo será impedido de matar Nestor pela mãe, que em sonho, conseguirá aplacar sua sede de justiça com as próprias mãos: “(...) não matasse Nestor, não manchasse de sangue as suas mãos. Confiasse e não temesse, ela haveria de guardá-lo" (OFP, 239). O anseio, todavia, retomará mais adiante: "E sobreveio um desejo conhecido, de cujo absurdo ele já estava convicto e que nem assim tornou-se mais débil: ir à cidade 
entender-se com Nestor Benício. Este desejo trouxe as mesmas raivas de antes (...)" (OFP, 245). Na verdade, o desejo de acabar com a vida de Nestor retornará vez ou outra a Bernardo, precisando esse de muito empenho para aplacar tal anseio. Em uma dessas circunstâncias, note-se a conclusão que se forma no íntimo de Bernardo: "Nestor começara a vencê-lo, violava sua paz, sua vida, merecia morrer” (OFP, 270).

Tristeza, angústia e outros sentimentos mesclam-se à ira de Bernardo. Como no caso de Aquiles, cuja ira adquire o tom melancólico e depressivo, a ira é revestida de sensação de tristeza e angústia. Veja-se a frase que procura dar conta do angustiado sentimento daquela noite trágica em que morre o filho de Bernardo: "No fundo de seus olhos azuis houve um lampejo, um brilho intenso de tristeza e raiva" (OFP, 1-2). Ira triste é mencionada novamente pelo narrador ao contar o episódio em que Nestor intentara se apoderar dos bois do irmão morto e ofendera Bernardo, chamando-o "homem sem palavra": "Mas vinha de onde aquela ira triste, aquele desalento mais profundo e mais grave, que se sobrepunha a tudo e o dominava?" (OFP, 113). Com a plena consciência do evoluir da delicada situação ao se opor aos desmandos de Nestor, Bernardo novamente sente a raiva esmagadora dentro de si, acrescida de impotência e tristeza: "Sufocava uma raiva presa e triste" (OFP, 250). Agora, a raiva acontece porque Bernardo se percebe carente do socorro da esposa para conter-lhe a ira, fato que aos seus olhos afigura-se um disparate, já que perante a sociedade, ao homem cabia a proteção da mulher.

Além de tristeza, a ira de Bernardo se junta ao medo, à insegurança e desconfiança. Isso transparece nas auto-indagações do atormentado Bernardo: "Se desatasse aquele segredo, a ira, a incerteza, o medo, confessasse tudo?" (OFP, 231). Essa ira parece "amarrada" aos vários incidentes apavorantes que se sucedem como os tiros em sua direção, na viagem de Vitória, por exemplo: "E a invisível ameaça, aquele 
assassino paciente, pronto a esperá-lo sem cansaço (...) açulava-o. Era como um laço, amarrando a sua ira" (OFP, 238).

A ira de Bernardo parece estar mesclada também à obstinação e desafio constante do perigo. Por exemplo, Bernardo sentia que precisava ir embora do Surrão. Desde que Miguel morrera e mediante a gestão opressiva que se anunciava por parte do irmão de Miguel, a atitude mais sensata, segundo seu próprio julgamento, seria partir e reiniciar sua vida em outras paragens. Todavia, fincava o pé na fazenda, mesmo com a hostilidade crescente de Nestor e seus subalternos:

"Miguel Benício morreu entre a noite de quinze a madruga de dezesseis de julho. Na quinzena seguinte e durante todo o mês de agosto (...). Bernardo poderia haver deixado o engenho, seguido a uma sorte mais benigna. (...) Longe de fazê-lo, adquiriu um garrote, (...) uma novilha" (OFP, 121).

Nem mesmo a possibilidade de um emprego o demovera da resolução de se manter firme no posto de barraqueiro do Surrão: “mesmo depois de saber (...) que um sujeito de Limoeiro andava procurando um homem (...) para irem os dois buscar um lote de cavalos na Bahia”.

E assim como em Aquiles, o detonador dessas reações afigura-se ser o orgulho ou a honra. Bernardo fora convidado a administrar o barracão, tendo sido por Miguel, elogiado e apoiado em todas as decisões e projetos, vendo suas atribuições ampliadas, gradativamente. Praticamente todo o Surrão estava sob suas ordens, e a ele caberiam as determinações administrativas. Por direito legal, após a morte de Miguel, Bernardo deveria prestar contas a Creusa e filhos, pois sabia que o Surrão não era, de fato, de propriedade de Nestor. Esse, porém, também conhecia o fato de que Bernardo alcançava a verdade da história. Afinal, fora o barraqueiro a primeira pessoa a quem Miguel convidara para ter o Surrão em seu nome, provisoriamente. Mas Nestor se fazia de 
inocente nesse quesito e tentava fazer valer a todo o custo o direito de propriedade, já que a compra era legitimada pela escritura feita em cartório. Com um tom veladamente autoritário, Nestor pedia e voltava a pedir a Bernardo para que se lhe submetesse a ele, acenando com benesses: “(...) Miguel the deu a mão? Eu dou duas” (OFP, 103). Bernardo, porém, recusava-se a participar de qualquer acordo com Nestor, como se vê no excerto a seguir: “- Não quero nada”. Nestor, efetivamente, estava a tocar num ponto de difícil laboração de Bernardo: seu orgulho. O esposo de Teresa não queria ceder à vontade ímpia de Nestor, nem mesmo com a ameaça de graves problemas à frente. $\mathrm{E}$ quanto mais o irmão de Miguel lhe provocava, mais o orgulho era ferido, gerando os sentimentos opressivos acima expostos. Mais adiante, Bernardo recusará certos favores de seu oponente - demonstrando, novamente, orgulho: “(...) Nestor, como que investiu (...) perguntou a quanto montava o prejuízo. Bernardo conseguiu aparentar calma e respondeu que aquilo não tinha importância” (OFP, 197). E Nestor se lamuriará: “- Eu quis comprar a plantação. Era um modo de ajudar. Não quer ficar rico?” (OFP, 234). Bernardo emitirá um comentário breve e seco: “- Nunca pensei nisso”. Em outra ocasião, note-se a proposta de amizade e parceria como meeiro:

\footnotetext{
“- (...) Quero ser seu amigo, provar minha largueza. (...) Quero lhe dar as minhas duas mãos, queira ou não queira. Você há de sair daqui um homem rico, um nome valorizado, cheio de poder na bruaca. Dou condições, dou tudo, capital, terra, coração, pasto. Quando você for um homem, quando tiver o ouro, o peso do orgulho, pode me largar. Mas por enquanto fica, pára na minha sombra, cresce e enriquece" (OFP, 233-4).
}

E, mais uma vez, a recusa desses bens: “- Nossos negócios não duram muito, Nestor. Eu vou embora”. O narrador confirma nossa hipótese, ao mencionar que Nestor procurava "deter aquele homem que se deixava esbulhar para ser fiel ao próprio orgulho" (OFP, 151) e inclui a informação de que o novo patrão chamava o adversário de "soberbo", advertindo em tom ameaçador: "Remédio de soberbo é força" (OFP, 
291). Em outra circunstância, Nestor ataca verbalmente o sentimento que move Bernardo - essa ira complexa, cujo cerne é o orgulho: "De tudo neste mundo, você não conhece é nada. Nada, só o orgulho. (...) Você e sua raça de soberbos sem vintém vai desaparecer do mundo" (OFP, p. 179). Nestor continuará o mesmo discurso em outra feita: "Peixe morre pela boca, mas Bernardo morria pelo orgulho" (OFP, 293). Fazendo uma auto-análise, Bernardo conjectura sobre sua teimosia na decisão de, apesar de todas as circunstâncias comprobatórias do perigo iminente, manter a resolução de enfrentar Nestor. Chega, enfim ao cerne da questão:

"Mas, ceder como, em que sentido? Aquele orgulho, de súbito advindo e logo abandonado, de ver na sua vida um caminhar seguro, inabalável, castigado, mas reto, vibrou em sua alma e ele viu nas concessões a fazer, concessões cuja natureza ignorava - sem que isto o deprimisse menos, pois era a simples disposição de transigir que ele afastava, temia aceitar e considerava mais grave -, um cotovelo, uma quebra de rumo em sua vida, que depois disso jamais seria a mesma. (...) Mas, de uma vez por todas, decidia: não curvaria a cabeça, não haveria de comprometer-se ante o olhar com que, sobrevivendo, julgaria mais tarde o seu passado" (OFP, 272). Bernardo conclui: “(...) não curvaria a cabeça”.

É interessante como o orgulho é ferido através da usurpação indevida de um objeto - um bem (ou bens) - na Ilíada, Odisséia e Eneida. Na primeira epopéia, a "causa" da grande ira de Aquiles é a usurpação ilegal do espólio de guerra que se the coubera, cujo ápice de valor afetivo era a bela cativa, Briseida. Na verdade, os bens pelos quais ocorrera a pendenga pareciam ser uma mera representação da causa subliminar do conflito: a disputa pela autoridade ensejada por Agamenon e aceitada como repto por Aquiles. Na Odisséia ${ }^{\text {xxxvi }}$, os bens do rei de Ítaca é que estão em jogo, os pretendentes ávidos por lançar mão de toda a riqueza do palácio. A epopéia insere a noção da irreverência, arrogância dos pretendentes revelando a ausência de respeito para com a autoridade de Telêmaco (presente) e do próprio Odisseu, que, embora ausente, não estava morto. Ao punir com a morte os pretendentes, Odisseu reputa-lhes o crime 
de atentar para com sua dignidade. Na Eneida ${ }^{x x v i i}$, a visão do talabarte de Palante é que provoca no herói toda a fúria em relação a Turno. O troiano percebe o adereço como um insulto à dignidade do guerreiro morto, o filho de um rei. E como Evandro, o rei em questão, era um nobre piedoso, ao contrário do que se mostrava Turno, urgia salvaguardar a honra do cadáver representada não apenas pelo corpo sem vida, mas também, pelas armas e vestes bélicas não conspurcadas.

Em O fiel e a pedra, na causa "objetiva" da ira de Bernardo não está envolvida uma bela mulher, como na Ilíada, e sim um conjunto de elementos: os bois do falecido Miguel, os quais, o irmão intenta usurpar dos legítimos herdeiros; a plantação de cará à qual Bernardo se empenhara em cultivar; o bezerrinho de estimação e o animal de montaria com que Miguel havia presenteado seu novo barraqueiro. Esses objetos - os bens, o tesouro familiar - e até as pessoas (Briseida), fornecem apenas um anteparo ao cerne da questão: o orgulho. A Ilíada mostra uma verdadeira queda-de-braço entre o rei dos aqueus e o maior de seus guerreiros, acontecendo algo similar entre Odisseu e os pretendentes (com direito a certames competitivos e tudo o mais) e, em menor escala, entre Enéias e Turno. No entanto, a disputa entre Bernardo e Nestor aproxima-se, em seus reais motivos, da havida entre Agamenon e Aquiles. Vejamos certas frases recheadas de prepotência advindas de Agamenon e dirigidas a Aquiles, evidentemente e abordando a decisão de tomar a cativa que o aqueu havia escolhido para si:

\footnotetext{
“(...) mas vou eu mesmo à tua tenda buscar Briseida, belo rosto, recompensa que te coube; verás assim quem pode mais; e que outro tema ombrear-se a mim como a um igual." (Il, I, 184-7 - grifo nosso).
}

Isso nos faz lembrar certas pérolas de arrogância emitidas por Nestor: “(...) mas eu dou uma lição a você" (OFP, 103) ou "Remédio de soberba é força, entendeu? Cada um no seu lugar. O que é de cima, em cima; o que é do chão, no chão. Hoje não tem 
mais apelação. É dobrar ou quebrar, ou enverga ou se dana" (OFP, 291). Ou ainda: "Vim com vigor, isto sim, impor um mando que é direito meu. Em qualquer tempo ou lugar, se beija a mão do senhor. E você quer violar, quebrar as leis do mundo, mas eu estou aqui para impedir" (OFP, 293). Continuando: "Hoje você tem de ficar na sua altura" (idem). E mais: "Comigo, manda quem manda e obedece quem serve" (OFP, 306).

E a reação a esse discurso opressivo? Diante do autoritarismo de Agamenon, Aquiles se rebelará: "Ditas normas aos outros; quanto a mim, não, nada / me ordenes, que, já não te vou obedecer" (Il, I, 295-6). Bernardo, por sua vez, contrariará o desejo de onipotência de Nestor, que almejava dominar como patrão (sem legalmente sê-lo) e ainda dobrar a "cerviz" do barraqueiro contratado pelo irmão: “- Quero avisar uma coisa. Para os trabalhos fora do barracão você só conta comigo até hoje" (OFP, 103). Se o rei grego planejava tirar todo o botim de Aquiles, optando, ao final, por deitar as garras no que mais detinha valor aos olhos do herói; Nestor, com sua prepotência, objetiva tirar quase tudo de Bernardo, em parte, conseguindo. Não obtém sucesso com um bem precioso, no entanto, o símbolo que conferia ao seu dono significados plenos, como autonomia, liberdade, esperança: o burro. E ainda mais: o símbolo de um sentimento que ele não logrou cultivar pelo próprio irmão. Sobre o lombo de seu burro, Bernardo será atingido por um tiro e em cima do animal, um Bernardo ferido - mas..., vivo! - será levado para a cura e uma nova existência.

Após a morte e enterro do filho, a ira voltara a mostrar uma de suas tantas faces: o orgulho. À sugestão de Miguel - o único a conceder-lhe uma oportunidade de trabalho - sobre a probabilidade de ser traído pela esposa, Bernardo reagira de maneira impulsiva e feroz - a ira a retumbar: “(...) aproximou-se e deixou cair a mão com violência, no ombro de Miguel: - Mais uma palavrinha dessa... O senhor pensa que eu viajo pra 
buscar desaforo?" (OFP, 89). Por ocasião da visita noturna do bando de Ubaldo, com a atitude de desconfiança do homem, a ira - tão alimentada pelo orgulho e senso de honradez - derrama-se pelo corpo de Bernardo, quase pronta a liberar-se em agressão fatal: “(...). Os punhos de Bernardo ficaram pesados de sua ira (...)” (OFP, 185). A conclusão do protagonista, sobre seu estranho modo de ser - estranho às contingências - corrobora com nossas reflexões de que a ira manifestada perante o trato com Nestor é a mesma ira que o move desde criança. Às vésperas do fatal acerto de contas, Bernardo considera sua posição em face de vida, no quesito fazer ou não concessões:

\begin{abstract}
"Sentia-se um guardião - mas de quê? Podia ir embora, nada o forçava a esperar. Mas não iria - protestou erguendo-se. Sempre fora assim e não havia de mudar, a não ser que os anos, dentro de sua pele, o substituíssem por um homem diferente. Se para viver era preciso afastar-se de uma certa linha, abrir os braços, servir a um ladrão, ser fiel aos infiéis, trair, ceder, então é que o mundo e a vida não haviam sido feitos para ele" (OFP, 270-1).
\end{abstract}

Enfim, o irado Bernardo, "sempre fora assim e não havia de mudar". E nesse ponto, diferencia-se da ira de Aquiles, tão marcada de cunho fortemente emotivo; paradoxalmente, possui seu lado lógico, pelo que se vê nos versos: "Mas fique de lado o que foi. / Não se pode manter um coração colérico perpetuamente. (...) " (Il, XVI, 60-2).

Aquiles insere uma espécie de prazo-limite para a duração dessa raiva: "Eu mesmo fiz uma promessa: / não esquecer-me da ira, até que a guerra, os gritos / me alcançassem as naus. (...)" (Il, XV, 63-5). Não olvidando o fato de que Homero aqui está empregando um recurso poético de antecipação dos fatos, o certo é que Aquiles impôs um tempo para que a ira acabasse e essa, pelo que o texto indica, vai perdendo sua intensidade. Por outro lado, a ira de Bernardo é crescente e sufocante, evoluindo de forma avassaladora e violenta, como o comprovam alguns incidentes: conversa com Nestor, comentário de Ubaldo, atitude de Xenofonte. No primeiro caso, depois de 
profanar o cemitério, preparando-o para a lavoura, Nestor tenta convencer o esposo de Tereza a entregar-lhe os bois. O irmão de Miguel profere um discurso filosófico sobre o isolamento dos que tentam ser diferentes - um recado à obstinação de Bernardo, em não se fazer afável para com o novo dono do Surrão. Bernardo ouve a enxurrada de argumentos, mas, presta atenção a um detalhe apenas: ao sentimento despertado por aquelas palavras, "pressentindo no fundo desse ódio um impulso secreto, que o próprio Nestor devia de ignorar" (OFP, 179). Esse ódio [ou ira, ou raiva] vai se fermentando dentro do barraqueiro e, conseguintemente, crescendo, mostrando-se dotada de preocupante potencial de violência e tal se verifica na atitude quase injustificada em relação ao vigia do Surrão, no episódio em que o homem surgiu entre as sombras da noite, após o grupo de Ubaldo deixar o armazém:

"Sem sentir, Bernardo se curvou sobre o balcão, e aproximou do chefe o rosto irado, de tal modo que o outro certamente ouviu sua respiração difícil. Sob essa cólera a ponto de romper-se, os olhos miúdos [do chefe do bando] vacilaram. A mão livre de Bernardo moveu-se: tocava ainda o balcão, mas já havia uma corrente, um laço misterioso entre ela e a garganta do outro. $O$ breve silêncio exalava qualquer coisa de particularmente sombrio, uma expectativa terrífica" (OFP, 186).

Naquela noite nervosa, despedidos os homens, Bernardo se assustara, novamente, dessa vez com um vulto esgueirando-se pelo quintal. Era o vigia, que não tendo feito nada de mal efetivo contra Bernardo a não ser eximir-se de guardar cabalmente a propriedade, escondia-se entre as folhagens, tentando não ser visto pelo barraqueiro. "- Correu, eu queimo", ameaçara Bernardo, e o homem, por fim, se mostrara, mas de forma zombeteira aos olhos de Bernardo. Diz o narrador:

"Ao vê-lo de perto, sempre rindo e saltando sua ira levantou-se. Sem dar importância ao rifle do gazo, agarrou-o pela camisa, à altura dos ombros e quase o ergueu do solo. Seu impulso era de jogar o homem ao chão, baterlhe, esmagá-lo, esmurrar-lhe a cara muitas vezes, espezinhá-lo depois. Mal 
podia respirar, já não via o rosto diante de si e trincava os dentes para não urrar" (OFP, 188).

Em outra circunstância, novamente obrigado a ouvir os argumentos persuasivos, de Nestor - e esses, enunciados em voz "cada vez mais suave", emoldurada por um "olhar terno", a ira manifesta-se como um balão de gás a inflar-se indefinidamente: A ira de Bernardo inchava (OFP, 198). Nesse ponto, a ira de Bernardo, é chamada, poeticamente, de "grandes ventos coléricos" e custa a ser contida. O protagonista assusta-se diante das mudanças que se lhe ocorrem no íntimo e se pergunta "que ato misterioso e horrível se gerava em seu espírito". Depois dessa citada visita de Nestor, Bernardo reflete e conclui uma verdade preocupante:

"Que lhe sucedia realmente? (...) Primeiro, fora o chefe do grupo ao qual abrira a porta. $\mathrm{O}$ furor crescia em suas mãos (...). Logo houvera o estouro com o vigia (...). Com uma lentidão, uma força e uma constância de raiz, seu coração gerava um ser destruidor" (OFP, 199-200).

A ira crescente continuará asfixiando-o. O narrador dirá, mais adiante: “(...) o ódio recrescia e dominava-o" (OFP, 207). A ira retornará ainda mais sufocante, no momento do entrevero:

"Quantas vezes, nas últimas semanas, envergonhara-se do ódio que o domava, aquele ferrão que lhe acendia a violência! Via agora que o ódio era uma coisa rara, paixão maior que a alma, impossível de caber num homem e de escolher um alvo. Sim, ódio era aquilo que sentia, que inflava e oprimia, aquela surda pressão, aquela entrega. Oh! As forças do amor. Mas onde estava isto? A quem amava? Ódio era aquilo, aquela indiferença hirta, aquela rendição. Aquele apodrecer da alma. Aquela noite, aquela escuridão. (...) $\mathrm{O}$ ódio sufocava-o, inchava, estava a pique de estourar. (..) Emparedado no ódio, ele tomava a consistência da caliça. Sentiu medo e raiva (..) Começou a chamar em seu íntimo o nome de Nestor. Era só o que podia conservá-lo uno - sentia. Era só o que podia resguardá-lo, mantê-lo dono de si. Se isto se partisse, ele também se despedaçaria, não seria mais ninguém, mais nada. (...)" (OFP, 307-8). 
No clímax do conflito, a ira de Bernardo, finalmente alcançara seu limite. Esse limite coincide com o fim, o nada. A alma se fende, se parte, esgarça-se:

"E de repente ele teve a impressão de que se rebentava, de que muitas fendas se abriam (...) e de que passara o derradeiro instante de salvarse. (...) Sabia que estava imóvel, intato diante dos homens. E no entanto, explodira com o seu ódio, devastava tudo, esvaziava-se, bramava sobre o mundo, sobre o mundo, aquele reino de maldade e covardia, onde tentara viver (...)"(OFP, 307-8).

Momentos antes de levar um tiro, Bernardo ainda sente a raiva: "O ódio sufocava-o, inchava, estava a pique de estourar" (OFP, 307). Portanto, Bernardo é dotado de uma ira muito parecida com a de Aquiles, no aspecto da multiplicidade de facetas, da intensidade, complexidade e causas, do grande motor (o orgulho). Mas diferencia-se pelo menos em dois grandes aspectos: a pré-existência e configuração ligada ao desenvolvimento. Em Aquiles, a ira multifacetária e indefinida surge no episódio da tomada dos bens, sem que tenhamos acesso à informação de que o sentimento se apresentara antes, mesmo levando-se em conta o ímpeto belicoso de Aquiles (a ira explosiva). A ira de Bernardo, no entanto, já se manifestara antes, nas situações exemplificadoras do alto grau de princípios morais a que se submetia o garoto: na consciência culpada pelo favor alcançado através do beijo, na infância, e ao desafiar a advertência materna quanto ao rio, na juvenilidade. Nessa ocasião, a ira se fizera um ingrediente poderoso na luta contra a impetuosidade das águas.

Em menor escala, outras "iras" xxxviii influenciarão a composição de Bernardo: a ira de Odisseu e de Enéias. O paciente Odisseu que sofre submisso cada um dos revezes que Poseidon lhe envia, ergue-se feito um leão façanhoso diante dos pretendentes e os mata. No entanto, essa fúria assume um caráter essencialmente punitivo, referendado pelos deuses. O piedoso Enéias, que mal tem coragem de falar a uma mulher exaltada, demonstra de igual ao modo, nos últimos versos do último livro de Eneida, um furor 
que soa estranho ao seu modo de proceder. E Virgílio justifica o ardor com o qual mata o antagonista, Turno: Enéias está vingando Palante, parceiro de guerra, filho do rei Evandro, que lutava em favor dos troianos. De acordo com a narrativa, Turno haveria se apossado de parte da indumentária de guerra de Palante, o que era ilegal e desrespeitoso, e que também indicava arrogância e impiedade, já que os reis lutavam segundo estatutos religiosos das guerras que exigiam a honrosa devolução dos mortos, preservando suas armas e vestimentas. Vale lembrar que a ruptura desse código de guerra traz sérios problemas na Ilíada, com Pátroclo profanando o cadáver de Sarpedon; depois, Heitor, fazendo o mesmo com o corpo de Pátroclo e Aquiles, por vingança, agindo mais acintosamente ainda, em relação ao cadáver de Heitor.

Inteligência, criatividade, astúcia

A inteligência e criatividade, às vezes denominada sabedoria, esperteza, astúcia, sagacidade, engenhosidade ou qualquer sinônimo equivalente ou aproximado, é qualidade das mais acariciadas nos heróis greco-romanos que citamos, particularmente em Odisseu ${ }^{\text {xxix }}$. Já na Ilíada, seu nome é acrescido de centenas de epítetos relacionados à sabedoria ${ }^{\mathrm{xl}}$ : multiardiloso; equiparado a Zeus em argúcia; multiastucioso; doloso em tramas, mente cavilosa; multi-engenhoso; Laertíade poli-astucioso; herói poliardiloso; multilouvado, aquéia glória; Poli-engenhoso; poliarguto; multiastuto; o pertinaz. O herói é constantemente convocado para situações complexas, como a viagem de resgate da filha do sacerdote Crises; a embaixada que se dirige a Aquiles, a fim de rogar pela volta do guerreiro às batalhas; a comitiva de espionagem no arraial inimigo e outras. $\mathrm{Na}$ Ilíada, a agilidade mental (e manual) de Odisseu o torna um otimista, inspirando e liderando outros à batalha (ao contrário do depressivo Agamenon, por exemplo). 
A Odisséia, logo de início, aborda essa característica de seu herói, ao apresentálo nos primeiros versos:

"Musa, reconta-me os feitos do herói astucioso que muito peregrinou, dês que esfez as muralhas sagradas de Tróia; muitas cidades dos homens viajou, conheceu seus costumes" $(\mathrm{Od}, \mathrm{I}, 1-3)$.

E sabemos que a inteligência (ou sabedoria, astúcia, esperteza e outros sinônimos) é o grande diferenciador do caráter de Odisseu em relação aos demais heróis pelos generosos epítetos que o autor de Odisséia insere ao seu nome: ardiloso, astucioso, astuto, claro, estremado, manhoso, mente fecunda, sábio, solerte ${ }^{\mathrm{xli}}$. A excepcional inteligência, argúcia, capacidade de solucionar problemas, clareza de raciocínio, sábio escrutínio exposta prodigamente na Odisséia ${ }^{x l i i}$, fazem desse herói um dos mais caros personagens da literatura grega, conforme se vê no comentário do estudioso e tradutor da edição de Odisséia que usamos nesse trabalho, Carlos Alberto Nunes, na introdução do livro, na versão que ora utilizamos: "Na figura de Odisseu viam os gregos o retrato do herói ideal, até mesmo nos defeitos: astucioso, sofredor, resistente, rico em recursos de toda natureza, que o faziam triunfar das mais delicadas situações" (Od, p.9). Essa astúcia [ou inteligência, ou esperteza, ou algo correlato] aparece em diversos momentos: na guerra de Tróia, particularmente com o famoso episódio do cavalo de pau, que, mesmo não tendo sido fabricado por ele, foi colocado às portas de Tróia por sugestão de Odisseu ${ }^{\text {xliii; }}$ no terrível evento do ciclope comedor de gente, quando o herói precisa pensar rapidamente em um plano para salvar a si e aos companheiros do gigante devorador de gente [“(...) Pensei toda sorte de astúcias e enganos, / por se tratar da existência e iminente perigo ameaçar-nos" (IX, 422-3)]; e em muitos outros momentos, até o final, quando enganará os pretendentes, fazendo-se passar por um velho pobre e fraco. 
Odisseu, efetivamente, é aquele herói que sempre tem uma solução para os problemas mais difíceis e essas soluções são tão inusitadas que despertam espanto e admiração da parte dos companheiros. Um grande exemplo é o famoso cavalo de Tróia. A idéia de ocultar os invasores na barriga do imenso cavalo de madeira foi de Odisseu. Todavia, a inteligência de Odisseu manifesta-se também em outra vertente. O herói é habilidoso em atividades que envolvam a mente aliada ao trabalho braçal. É uma variação da inteligência criativa de Odisseu, a engenhosidade que transparece em muitos adjetivos, dentre os quais, na tradução de Campos, recolhemos como exemplo, as expressões: multi-engenhoso e poli-engenhoso. Além das incríveis idéias, portanto, o herói ainda demonstra engenhosidade para atividades manuais, sendo descrito como engenhoso, de grande inventiva ${ }^{\text {xliv }}$.

E se na Ilíada, é apresentado como exímio marinheiro ${ }^{\text {xlv }}$, na Odisséia, o esposo de Penélope, não só navegará por desconhecidos mares, mas construirá, ele mesmo, uma jangada ${ }^{x l v i}$ para enfrentar esses mares, mostrando no minucioso trabalho toda a verve construtora dos navegantes do passado. A vocação dos antigos gregos como exímios construtores navais, bem como marinheiros ousados e experimentados, aparece no trabalho perfeccionista de Odisseu, assessorado por Calipso. Embora estivesse realizando um trabalho aparentemente simples, Odisseu se entrega ao mesmo como se fosse grande obra. A dedicação à arquitetura de uma jangada para um homem só é tão cuidadosa quanto a construção de um navio de carga [mais um sinal da vocação grega para a marinha mercante]. Não ficou de fora o trabalho de costura da vela, o qual nos remete aos ofícios ligados à arte de trabalhar em tecidos, ocupações tão prezadas por Osman Lins, sendo a de alfaiate merecedora de sua profunda admiração, já que era a profissão do pai ${ }^{\text {xlvii }}$. No caso do Odisseu-costureiro, ao menos naquela ocasião, mais uma vez, o concurso bem-vindo de Calipso, a tecelã divina $(O d, \mathrm{~V}, 62)$, apresentando a 
Odisseu um tecido, certamente confeccionado por ela. O prendado Odisseu construíra até mesmo a cama ${ }^{x l v i i}$ em que dormia no palácio de Ítaca. Na Odisséia é com detalhes que o herói descreve o belo e resistente móvel de sua lavra, não se esquecendo de indicar, inclusive, a madeira usada como matéria prima no especial trabalho: uma oliveira frondosa que crescera no pátio de seu palácio.

Virgílio parece inspirar-se nessa atrativa qualidade de Odisseu e acresce o epíteto astucioso ao nome de Enéias uma vez; contudo, esse dado é quase insignificante, pois se refere a um comentário de Turno a Camila, cujo teor era a habilidade estrategista do tróico. Sabemos, também, que Enéias buscava um "modo mais astuto” (IV, v. 428) de falar com Dido e expor-lhe sua necessidade de partir de Cartago, mas, embora sofra com uma idéia aqui e outra acolá, sua mente se desgoverna e nada consegue idealizar. Portanto, nada percebemos em Enéias que demande a noção de engenhosidade ou inteligência notável. Vêem-se nesses exemplos que astúcia e engenhosidade, assim como qualidades similares, são características tênues em Aquiles e Enéias, bastante salientadas, de outra forma, no perfil do herói de Odisséia. E Osman Lins parece ter se inspirado nesse multitalentoso herói ao cinzelar seu protagonista. Bernardo é apresentado como um homem inteligente e hábil. Mesmo não mencionando a escolaridade de Bernardo, dado que justificaria sua acuidade mental, antevemos um protagonista dotado de grande capacidade de escrutínio em situações probantes, bem como habilidade em algumas áreas do conhecimento não necessariamente ligado aos bancos escolares. Jovem ainda, Bernardo leva a cabo e com êxito a incumbência materna de se deslocar até o Estado de Alagoas, onde morava o irmão - o ingrato e perdulário Caetano - que um dia se fora de casa nunca havendo retornado, nem ao menos para uma mera visita à mãe. $\mathrm{O}$ motivo dessa longa jornada era levar o dinheiro da venda de mais uma das três casinhas que o pai de Bernardo deixara à família. A 
primeira das casas já havia sido vendida por ocasião da saída desse irmão. Inexperiente em outros aspectos, como por exemplo, no amor, Bernardo, ainda bem jovem aprende a arte de comercializar e se embrenha pelos vilarejos do sertão pernambucano, oferecendo mercadorias diversas, como "figas, voltas, medalhinhas de alumínio, retratos do Padre Cícero Romão" (OFP, 24) ou vendendo e comprando burros. Depois de casado e necessitando fixar moradia e conceder mais atenção à esposa, Bernardo consegue um emprego no posto fiscal da cidade, como já mencionamos. E como o abordado, percebe as falcatruas do agente fiscal. Efetivamente, Bernardo não se porta como um funcionário qualquer, alienado do que lhe ocorre à volta ou embrutecido pelo contato com as mazelas morais que fazem parte do dia-a-dia de caminhoneiros e o fiscal. Ao empossar-se no emprego que Miguel lhe oferecera, Bernardo se sai bem, embora nunca houvesse exercido a atividade anteriormente. Administra com eficiência o barracão de Miguel (o armazém de secos e molhados comum nas zonas rurais) e, gradativamente, aceita tarefas administrativas na fazenda, propriamente dita, como o pagamento dos salários dos funcionários, o gerenciamento das terras e plantações. Na ocasião em que é apresentado a Nestor, Bernardo apreende, quase num átimo, o sutil antagonismo que esse exerce em relação ao irmão mais velho. Sendo chamado para Vitória, por conta da morte repentina de Miguel, mesmo sendo um homem simples e não dado à violência, Bernardo faz ligações de fatos e sensações intuitivas e é capaz de compreender plenamente o que ocorrera efetivamente com o patrão, ao ver o corpo sem vida jogado pela escada. Depois do enterro de Miguel e embora destituído das benesses intelectuais advindas da vida acadêmica, o barraqueiro apreende rapidamente a mensagem oculta nos diálogos escusos de Nestor. As palavras do narrador que dão conta de seu pensamento na primeira visita do irmão de Miguel demonstram as conclusões inteligentes de Bernardo: "Parecia inseguro, mas visava certeiro seus propósitos. 
Sinuosos caminhos, porém sem desvios - era preciso cuidado" (OFP, 101). A intensa capacidade de reflexão, a mente envolvida em longos monólogos internos, leva Bernardo a se sobressair dos homens comuns de seu tempo. Ao visitar Miguel para pedir uma oportunidade de emprego para Antônio Chá, Bernardo é elogiado pelo rico homem e reflete no que haveria verdadeiramente nos elogios, quem sabe um propósito maldoso. Ele pensa: "Ou será que haveria, nas palavras de louvor, uma intenção cruel" (OFP, 30). Após a morte do patrão e depois da visita de Nestor, com as propostas sobre o gado, Bernardo passa a desconfiar da verborragia constrangedora do outro: "A confiança nas boas intenções de Nestor, se não tinha firmeza, tornou-se ainda mais frágil - ou deixou de existir" (OFP, 107). Tendo sido sua plantação alvo de ataques anônimos, Bernardo deduz que o novo "dono" do Surrão fora o autor do ato - ou, ao menos, o estimulara: “- Se ele não mandou, estimulou” (OFP, 195). Em outro nervoso diálogo com Nestor, comunica sua saída da fazenda e o novo patrão lhe pergunta quando isso se daria. Bernardo imagina interiormente quais os reais sentimentos envolvidos por detrás dessa indagação. É interessante a maneira como se dá a íntima inquirição. Vejamos: “A pergunta fora dominada, não revelava a mínima paixão. Mas os olhos... Que intenções, que dissimulada espera havia neles?” (OFP, 234). E a desconfiança prossegue com a repentina visita noturna de um grupo de homens sujos, armados e maltrapilhos. Bernardo suspeita de que Nestor fosse o mandante de alguma ação nefasta contra ele. "Teria o chefe, naquela noite, servido a Nestor?” (OFP, 296). Acossado por Nestor e seu bando, Bernardo, de certa forma, se sente abandonado pelas autoridades judiciais de sua cidade. Desde a morte de Miguel, Bernardo desconfiara de um conluio entre Nestor e o delegado, João Cardoso. No dia em que fora encontrado o corpo do patrão, Cardoso demonstrara, publicamente, hostilidade em relação a Bernardo. Essa impressão cristalizara-se com a posterior atitude do delegado, ao passar 
por ele, na rua, obviamente fingindo não perceber sua presença. $\mathrm{E}$ isso, no mesmo dia em que Bernardo seria alvo dos tiros na estrada, ao voltar para casa: "A idéia de que João Cardoso recuara sem vê-lo (...) nem sequer passou pela mente de Bernardo. Houvera naquela atitude qualquer coisa de falso (...)" (OFP, 226). No Surrão, dias antes do forjado balanço (o qual, na verdade, era um acerto de contas à moda dos coronéis sertanejos), Bernardo desconfiara da atitude da amásia de Cizilião que fora ao barracão, aparentemente demonstrando desejo de avisar sobre algo importante: "Por que a vigilância [vendo Cizilião a rondar a mulher], imaginou Bernardo, que podia Genuína contar-lhe? Que segredo?" (OFP, 245). Até mesmo o fiel Antônio Chá não escapara à desconfiança de Bernardo: “(...) parou à sombra do cajueiro seguinte, apreensivo com os movimentos do amarelo (...) como que mantendo-o sob pontaria. Afastou a desconfiança, não era possível que Antônio viesse com propósitos maus" (OFP, 273). Enfim, como no caso de Odisseu, Bernardo se mostrava um homem desconfiado das pessoas e circunstâncias que o cercavam.

Outras reflexões o ajudam a elaborar estratégias de retirada, de espera atenta ou de enfrentamento. O esposo de Teresa tece longas conjecturas sobre a vida, sobre as circunstâncias que o acometem. Pensa nele, em seu caráter e desconfia de suas intenções recônditas: "Melhor ir embora, quanto antes, tentar outra vida. Não ceder ao seu ódio, à sua desconfiança” (OFP, 206). Sozinho no barracão, a esperar Nestor, Bernardo tenta uma estratégia eficaz:

"Pensar, medir, tomar posição. Situações como a sua exigiam uma espera, uma preparação. Por que estava ali? Por que mandara o empregado embora e deixara a casa aberta, como se nada mais lhe importasse? Qual a medida real do fracasso de Antônio e até que ponto isto prejudicava-o? Mas devia mesmo pensar nisto?" (OFP, 269) 
E Osman Lins nos leva a pensar que, ao burilar seu romance, de fato buscara inspiração no perfil do ardiloso Odisseu. Bernardo, homem simples e inculto, mostra-se sobremodo criativo na engenhosidade para invenções práticas e faz-se dotado de acuidade mental que o diferencia sobremaneira dos demais homens de seu tempo. $\mathrm{Na}$ juventude, Bernardo dedicara-se ao aprendizado de uma inusitada atividade não mais exercida - consertos de relógios ${ }^{\text {xlix }}$ : "Travara amizade com um falsário por nome Marinheiro, que lhe ensinara a consertar relógios, a pretexto de domar-lhe a paciência" (OFP, 9). O instrutor se tornara um dos raros amigos que tivera Bernardo. Ao que tudo indica, Marinheiro era um sonhador que buscava um dia, encontrar minérios de ouro à flor da terra. De qualquer maneira, com essa discreta informação conhecemos um pouco mais da habilidade manual do esposo de Teresa.

O narrador nos fala, também de outra aptidão de Bernardo: confeccionar e reparar brinquedos do sobrinho Ascânio'. Veja-se o quanto o tio intervira na vida do pequeno Ascânio: fizera para o menino "os primeiros corrupios", ensinara o menino brincadeiras e atividades de criança, como "aparar pião no ar, a fazer papagaios, a empiná-los" (OFP, 16). Por ocasião da morte de Miguel, quando viajara do Surrão para a cidade, chamado às pressas em vista de haverem encontrado o corpo sem vida do patrão, note-se o que o rapaz pensa, enquanto imagina como despenderá o tempo livre que terá até o enterro. Bernardo conjectura em visitar a sogra, que criava o sobrinho órfão, mas logo se lembra das ferinas críticas que teria que ouvir. Depois, prevê mentalmente outra possibilidade - dar atenção ao garoto, a quem prometera um brinquedo especial: "Mas havia o menino, conversaria com ele. Poderia armar o papagaio de seda que lhe prometera, estava em tempo, só no fim do mês começariam a soprar com força os ventos" (OFP, 97). Como apreciava caçar passarinhos, passatempo que lhe lembrava a juventude, Bernardo fabrica até mesmo uma arma de caça artesanal, 
útil nas caçadas que planeja fazer com Antônio Chá. Também restaura outra para si. Note-se a imensa criatividade no uso do material empregado para a confecção do artefato: “(...) fez para o empregado uma espingarda de cano de guarda-chuva, ajeitou para si próprio uma velha espingarda enferrujada (...)" (OFP, 65). As armas serão relegadas à inutilidade em vista da reação de Teresa aos primeiros pássaros abatidos pelo esposo e seu companheiro. Em razão do sofrimento da esposa ao ver os pequenos corpos feridos de morte, Bernardo desiste de caçar o que quer que seja. Além desses exemplos de habilidade prática ou técnica, há que se lembrar da vocação para a construção de benfeitorias na fazenda, o plantio da terra, o comércio no armazém e o cuidado com os animais. Certa vez, num exemplo de criatividade, dá a Antônio Chá a ordem de erguer uma cerca de varas na vertical, em lugar da idéia proposta pelo funcionário: “- Não quero saber disso. Varas em pé, apontando para cima. Cerca de varas deitadas, devem ter sido inventadas por ladrões, que saltam e não se espetam" (OFP, 64). Outra demonstração da habilidade de Bernardo em atividades envolvendo trabalho com as mãos surge com a menção da modelagem de uma pedra de um velho e usado moinho que adquirira: "adquiriu quase de graça um moinho do qual uma das pedras se quebrara e decidiu arredondar no escopro a outra mó (...)” (OFP, 65). O árduo trabalho com a pedra torna-se útil para desafogar seu espírito atribulado ${ }^{\text {li. }}$

"Em suas horas livres (...) voltava ao quarto que fazia as vezes de oficina, tomava o escopro, o martelo, ia tentando arredondar a pedra do moinho. Pensava, enquanto isso, como ordenar a sua força, a sua resistência" (OFP, 124).

Desse modo, quanto às nuanças da inteligência de Bernardo, essa se manifesta não ligada à astúcia e simulação que observamos, tão nitidamente, no perfil do protegido de Atena. De fato, não veremos Bernardo enganar ninguém; ao contrário, deparar-nos-emos com um ser angustiado frente à possibilidade de obter quaisquer 
favores mediante agrados, como é o caso do beijo na mãe, dado com a intenção de nadar no rio. Bernardo é inteligente, mas, diferentemente de Odisseu, não labora em causa própria, seus "engenhos" não são espetaculares, mas confortam o coração do sobrinho órfão, e, num efeito pragmático, podem operar para um fim específico de renovação, como no caso do moinho consertado.

As idéias do esposo de Teresa não provocam grandes mudanças no mundo, não encontram uso criativo para um "cavalo de Tróia". Bernardo, pois, é um homem do povo e suas idéias acompanham seu nível cultural e a experiência comunitária; no entanto, essas idéias o aproximam do modelo de bondade, sensatez e retidão de Odisseu, sendo benquisto por tais qualidades. A sogra concluirá ao final da história, que o genro é digno de admiração exatamente pelas qualidades que ela criticava. Ao cuidar de Bernardo ferido, Suzana se comoverá: "muitas vezes, sozinha, contemplava aquele homem ferido, tocada por qualquer coisa de loucamente nobre de que ele parecia ser um servidor - e ante a qual ela começava a render-se" (OFP, 312).

\section{Prudência e sensatez}

A prudência - mesclada à sensatez - é outra virtude dos heróis. Por mais absurdo que pareça, na Ilíada, o herói máximo não é imprudente o tempo todo. Aquiles, apesar de impetuoso, aceita a ordem de Agamenon no sentido de lhe tirar Briseida; mais adiante, aceitará o pedido de perdão da parte do rei e oferecerá, junto a esse, sacrifícios expiatórios. Na Eneida, embora o vocábulo não compareça, notamos a característica bastante evidente nas ações de Enéias, como por exemplo, ao segurar firme a mão do filho, enquanto fugiam da cidade de Tróia, a cortesia com que trata a rainha Dido ao aportar em seus domínios, a reticência em informar à mesma de sua partida de Cartago, a busca de auxílio junto ao rei Evandro para enfrentar Turno e outras ações em que o 
comedimento e a sensatez dão o tom. Na Odisséia, porém, o narrador considera o herói prudente $^{\text {lii }}$, epíteto que se repete dezenas de vezes. Quando a palavra não se expressa assim, encontramos seus correlatos, como sensatez, cuidado e outras, como no exemplo do excerto de verso: "dos homens o mais sensato" (Od, XXIII, v. 209-10), o que se percebe em vários eventos: no trato com Circe, ao efetuar aliança juramentada; nas gentis palavras dirigidas a Polifemo; na falsa história contada a Atena disfarçada; no disfarce de velho, ao se apresentar no palácio. Calipso ${ }^{\text {liii }}$ comenta que Odisseu não falava nunca por falar, mas pensava no que desejava verbalizar, mantendo a diplomacia para dizer o que lhe ia à mente, uma característica de pessoas inteligentes e sensatas. A sensatez de Odisseu, até mesmo ligada aos aspectos aparentemente banais da vida - e, no entanto, sumamente importantes - aparece no comentário que faz ao rei Alcínoo, quando esse lhe pede que continue narrando suas aventuras pela noite adentro, se possível até que o dia amanhecesse: "Há tempo para o repouso e, também para grandes discursos" (Od, XI, 379). A grande arma de Odisseu é o domínio de seu espírito, a temperança, tão preciosa aos gregos. Odisseu era capaz de ouvir ofensas (como a de que se parece mais com um comerciante inescrupuloso do que com um atleta, comentários emitidos por um dos nobres do rei Alcínoo), pesá-las e, se bem que aborrecido, responder com classe e dignidade, como o faz, efetuando digressões sobre as $\operatorname{aparências~}^{\text {liv }}$. Aliás, as virtudes de Odisseu em sua epopéia, são muitas e justificam o fato de a narrativa desse herói haver caído no gosto popular. Sobre esse fator, leiamos o que diz Carlos Alberto Nunes:

"As qualidades que caracterizam o herói da Odisséia diferem essencialmente das de Aquiles, a figura central da Ilíada. Aquiles é o guerreiro jovem e arrebatado, que, por não saber dominar as paixões, causa a morte do amigo, de grande número de companheiros e precipita o desenrolar dos acontecimentos de que decorre o seu fim prematuro. O herói da Odisséia, pelo contrário, aparece-nos como homem maduro, de grande e variada experiência e com admirável domínio de si mesmo, diferindo, em 
tudo isso, tanto de Aquiles, como do próprio Odisseu, que ficáramos conhecendo na Ilíada" (Od, introdução).

Efetuando auto-análise, o que faz costumeiramente à exaustão, Bernardo não se considera a virtude da sensatez uma de suas qualidades. Diante da morte do filho, em virtude da demissão do emprego, ele pensa: "E fora tão insensato o que fizera!" (OFP, 2). Perante o filho que deixa a vida, ele se recordará da angústia que sentira ao perceber que as portas se fechavam para ele, até mesmo nos empréstimos, que dolorosamente era levado a solicitar a um e a outro. Lembrando-se da atitude esquiva dos concidadãos, supusera o que eles pensariam sobre ele: "Todos têm juízo, todos acham que eu pedi demissão porque quis (...)" (OFP, 4).

Com a relação entre ele e Nestor, desgastada pelo desafio e insubmissão, Bernardo intui que precisa deixar o Surrão, que, legalmente, pertence agora ao irmão de Miguel. Essa seria, evidentemente, a atitude mais sensata que Bernardo poderia tomar. No entanto, é o oposto o que ocorre, como já vimos: Bernardo permanece na fazenda e ainda adquire outros animais, abrindo mão, inclusive, de uma proposta de trabalho para fazer o que ele realmente gostava: viajar. A situação na fazenda acaba se tornando insustentável, com Nestor indo e vindo sem nem ao mesmo cumprimentá-lo, sinal de que a condição de adversidade se instaurara, efetivamente. O narrador conclui: "Motivos de voltar para a Vitória, ainda que sem meio de vida, sobejavam. Mas ficou" (OFP, 122). Mais a frente, com as constantes ações provocativas do novo patrão Bernardo pensará em capitular, dizendo a si mesmo que não está sendo prudente: "Nestor, sendo inimigo poderoso, era impossível resistir-lhe sempre. Insensatez não ceder" (OFP, 145). O próprio Nestor, tentando convencer o barraqueiro a ser-lhe favorável, considera Bernardo insensato, ao enunciar a frase: “- Vamos falar como gente de juízo" (OFP, 151). E, ao final da narrativa, depois de tantos tropeços, após quase 
perder a vida na estrada, sob tiros vindos de um desconhecido, depois de continuar se negando a compactuar com Nestor, ainda resta em Bernardo a impressão de que não agia sensatamente. $\mathrm{O}$ esposo de Teresa se angustia com sua situação, ali na fazenda, sozinho, aguardando um acerto de contas que ele suspeitava ser uma farsa:

"Era mesmo possível que ele fosse um louco, em recusar toda sorte de acomodações. Que senso, por exemplo, tinha aquela espera? Que teimosia o obrigava a ficar? Era um homem sim. Mas também era humano pensar, medir as conseqüências, escolher o caminho mais sensato" (OFP, 270).

Ao contrário da lógica de Aquiles e da prudência de Odisseu, Bernardo mantém sua ira até o fim. Ao final da narrativa, prestes a enfrentar, pela última vez, Nestor e seus jagunços, Bernardo espera o fatal encontro, sozinho, sem a força da companhia de Teresa. Os pensamentos que passam por sua mente aflita são desalentadores. Sente que sua ira, seu ódio cresceu demais e o domina por completo. Racionaliza que perdeu a batalha para aquela força negativa que se desenvolveu em seu íntimo. Agora, sozinho e desesperançado, já não restavam mais nem os escrúpulos ligados ao Bem: "Não havia mais ninguém, ninguém. Nestor começara a vencê-lo, violava a sua paz, sua vida, merecia morrer" (OFP, 270). Dois Bernardos parecem digladiar-se na angustiosa espera. Um temeroso, outro, repleto de orgulho por ter se mantido firme. Desse duelo, uma sensação de tranqüilidade se instaura em sua alma. O motivo se expõe: "Não mais o oprimia o ódio aflito de antes" (OFP, 284). Teria o senso alcançado a vitória? Somente por pouco tempo - a ira retornará em grande intensidade, mas será refreada, definitivamente por uma espécie de grito interior que o protagonista não saberá bem definir. Talvez fosse mesmo o senso da melhor postura no momento... Assim, mesmo se manifestando apegada aos questionamentos e culpa, a sensatez de Bernardo estava sob os ditames dos princípios morais. Esses princípios, ligados ao Bem, não o deixarão 
cometer atos de desatino. A prudência se mostrará como tal, mesmo que tarda - ou após ouvir vozes externas. Prudência e sensatez não permitirão que Bernardo aja em contrariedade com sua consciência. E isso acontecera desde o princípio. Depois de pedir demissão do emprego e em face das negativas de chance de trabalho ou até mesmo empréstimos esporádicos, remoera os fatos anteriores, pesando os fundamentos pelos quais havia agido no caso da demissão e concluíra em diálogo com a esposa sobre sua aparente insensatez:

“- Mesmo agora, se tivesse que decidir, eu fazia o mesmo. Apesar de tudo, fazia de novo o que fiz. Esse prefeito agora é um ladrão (...). Eu posso estar errado, mas não estava em mim continuar. Outro qualquer ficava, lavava as mãos" (OFP, 4).

Assim é a sensatez e prudência de Bernardo: aparentemente oposta à de Odisseu, mas fundada solidamente nas leis morais que o próprio Bernardo nem entende completamente. Algo dentro dele o impede de agir contra essas leis e nessa condição, pode até mesmo parecer insensato. Na verdade, sua prudência é subjugada à lei moral interna, que o conduz e determina seus passos.

\section{Impulso construtor}

Aquiles e Odisseu são dois grandes destruidores de cidades. O primeiro, conhecido pelo esforço em arrasar cidades e famílias inteiras e o segundo agindo de modo semelhante, sendo muitas vezes chamado eversor de cidades $^{l v}$. Tal ocorria, sabemos, por conta dos inúmeros saques às cidades circunvizinhas à Tróia, investidas que sustentavam os guerreiros e ainda forneciam acréscimo de riquezas aos reis convidados. A Odisséia inicia contando sobre a atuação de Odisseu na tomada de Tróia: "Musa, reconta-me os feitos do herói (...) que muito peregrinou / dês que esfez as muralhas sagradas de Tróia" (Od, I, v. 1-2). Enéias, por sua vez, sai de Tróia para 
fundar uma cidade. Todavia, uma qualidade interessante que alguns heróis apresentam é o impulso construtor em relação a terra, que se manifesta nas tarefas de administrar e dele retirar o fruto do trabalho, produtos necessários à continuidade da vida. Esse olhar $^{\text {lvi }}$ (bastante pragmático no caso de Odisséia) transparece nos elogios de Odisseu ao pai, Laertes, pelo incansável cuidado do vicejante pomar; nos comentários do herói sobre o país dos acomodados ciclopes (quando contava a estada entre eles, na corte do rei dos feácios) que não laboravam na terra, recolhendo dela apenas o que nascia espontaneamente; na descrição que faz a Penélope do jardim e horta de Alcínoo. Enéias, por outro lado, diferenciando-se de Aquiles e Odisseu, é o grande construtor de cidades. Já ao chegar à cidade de Cartago, que se fazia erigida por outra corajosa construtora, Dido, Enéias auxilia a rainha na portentosa tarefa a que a mulher se propunha. E percebemos a ênfase no aspecto construtor mencionado no discurso de Mercúrio. Diz o narrador sobre o evento: “(...) viu a Enéias. Muros erguendo, casas renovando (...)" (En, IV, 380-1). O mensageiro celeste admoesta Enéias: "Fundas Cartago? Certo que edificas / Uma linda cidade! Femeeiro! / Homem das tuas coisas esquecido!" (En, IV, 389-91). O narrador de Eneida insere um detalhe curioso nesse encontro de Mercúrio com Enéias: as vestes do último. É interessante a representação simbólica desse fator, pois Enéias se traja com o manto feito pela esposa e porta uma espada que Dido lhe dera, ou seja, ao assumir o manto real, naturalizara-se cidadão cartaginense e se olvidara por completo - ou, ao menos tentara fazer os deuses esquecerem - de sua missão: de que ele deveria construir outra cidade, em outro local, com outra esposa.

Em $O$ fiel e a pedra, encontramos um Bernardo que também se mostra construtor, em certo sentido, nesse caso, em ambos os aspectos: edificador de cidade (mesmo que essa seja metafórica), bem como um engenhoso lavrador a construir (ou 
reconstruir) um espaço pujante em termos de natureza no que antes havia apenas abandono. Quando vendia burros a Miguel e ia entregá-los na fazenda do comprador, Bernardo extasiava-se com a paisagem do relegado Surrão, mesmo antes de ali morar: "Tinha a sua beleza, o Engenho, agora de fogo-morto. Açude, regato perene, muitos cajueiros, cana, filas de eucaliptos. As redondas elevações. O espesso bamburral, ao longe (...)" (OFP, p. 28). O protagonista parece sensibilizar-se com a natureza em geral, o que se vê nas impressões que o acometem durante uma viagem de Vitória ao Surrão, suavizando os sentimentos angustiosos:

"Baixadas cobertas de mato estendiam-se além das cercas, canaviais em pleno corte eram atravessados, montes sucediam-se ao longe, verdes. Vez por outra, um casal de pássaros cruzava a estrada em vôo rasteiro, desaparecia nas moitas. (...) cercado pela calma das paisagens, era difícil a Bernardo guardar as mesmas disposições que o haviam perseguido noite a dentro" (OFP, 144-5).

Chegando ao Surrão, já instalado, Bernardo observa o abandono das terras do patrão, um reflexo da atitude do mesmo, para com a vida. O fogo-morto, metáfora para o engenho desativado, remete ao abandono, à desesperança, à morte: "E o mato crescia, invadia tudo (...). Miguel é um homem de fogo-morto" (OFP, 47-8). Mas, a essência do Odisseu pragmático e do Enéias construtor [frustrações amorosas à parte] ressurge intensamente em Bernardo. O esposo de Teresa enxergará possibilidades no Surrão abandonado e tentará modificá-lo através do cultivo da terra e da criação de animais, bem como da ativação de um moinho que adquirira - enfim, o reavivamento do fogo. E tal acontece, gradativamente: a velha fazenda relegada às serpentes e ao mato recuperase, viceja pelo espírito edificador de seu novo arrendatário. Aproximando-se do Odisseu, dotado de conhecimentos em agricultura e admirador do bom trabalho com a terra, Bernardo não apenas se dedica ao comércio no barracão, mas faz uma roça: "E a plantação de cará, na encosta do monte, verdejava (...)" (OFP, 104) e ajuda a esposa no 
jardim, orientando Antônio em relação à cerca para proteger os canteiros do jardim em que foram plantadas "cristas-de-galo, violetas, dálias, margaridas, rosas" (OFP, 64). Depois, vêm os bichos. O cheiro da vida se faz nas plantações, na criação de animais, no entusiasmo de Bernardo, Teresa e Antônio. No caso de Bernardo, o ímpeto construtor é interrompido pelo irmão de Miguel, que ordena [ou influencia] interferências destrutivas, como a desativação do cemitério, a destruição da roça de cará, a morte do bezerrinho, e ao fim tentará usurpar tudo o mais que restara da tentativa de edificação da vida patrimonial de Bernardo. Mas, apesar dessa interrupção, ao final se verá que o protagonista conseguiu construir sua vida. Torna-se um mercador itinerante, como o desejava e continua a relação bem cuidada do casamento.

\section{Piedade}

Sabemos que a extrema dedicação aos deuses, à pátria e à família é denominada, na tradução clássica, piedade - vocábulo oriundo do latim, pietas, -atis ${ }^{\text {lvii }}$, por sua vez, proveniente de pius. Piedade, no sentido de reverência aos deuses, é um atributo dos heróis homéricos. Aquiles, por exemplo, é chamado "caro a Zeus" (Il, I, 4) e demonstrase religioso e obediente às divindades. Um exemplo desse fator de seu caráter é o que ocorre após a vingança de Febo Apolo à atitude de Agamenon em relação ao velho Crises. Aquiles é quem sugere ao rei que se procure ajuda religiosa para lhe perguntar sobre a conduta a seguir no aplacar da ira divina ${ }^{\text {lviii }}$. Com respeito à piedade no sentido de devoção à pátria, Aquiles lutaria por Ftia, caso os troianos tivessem-na atacado, mas estava na guerra em apoio à empreitada bélica de Menelau, conduzida por Agamenon ${ }^{\text {lix }}$. De certa maneira, a pátria de Aquiles seria beneficiada com a guerra, pois os tesouros apreendidos nas investidas às cidades vizinhas iriam para Ftia. Como era usual a parceria, digamos, mercenária, Aquiles, estava, mesmo sem razão de ordem política, 
laborando em prol de sua pátria. Acerca do sentido de piedade como dedicação à família, vimos um Aquiles saudoso de sua Ftia e ansioso por constituir uma família ${ }^{\mathrm{lx}}$. Demonstrando delicadeza de sentimentos, Aquiles manifesta publicamente seu amor e respeito pela esposa, em copioso pranto e, apesar de se queixar da honra conspurcada, o guerreiro refere-se, reiteradamente, ao amor que dedicava a Briseida. Um dos momentos ocorre nos versos a seguir:

"Todo homem reto, merecedor do nome, ama sua esposa e a ampara, como eu de coração, amo a minha, ainda que a tendo conquistado à lança" (Il, IX, v. 342-4).

A Odisséia também mostra seu herói ligado aos deuses, à pátria e à família. No primeiro quesito, Odisseu está sempre pronto a oferecer sacrifícios às divindades e respeitar-lhes a vontade, ao menos é o que lembra Atena a Zeus, ao perguntar-lhe se não o sensibilizavam as dores de Odisseu, afastado da pátria e do $\operatorname{lar}^{\mathrm{lxi}}$. A epopéia de Ulisses, através de seu herói, aborda a inadaptação do estrangeiro e o valor da família e da pátria em detrimento da riqueza e esplendor de uma terra que não é a própria. Calipso vai encontrar em prantos o forte Odisseu, que chorava de saudade da esposa e de Ítaca e o protagonista, contando ao rei Alcínoo sobre sua demorada estada na luxuosa gruta de Calipso e na rica residência de Circe emite um triste comentário sobre o valor da pátria $^{\text {xii }}$. No mesmo sentido, o Mendigo/Odisseu concluirá, falando a Eumeu, o porqueiro: "Nada há pior para os homens mortais, do que errar sem destino" $(O d, \mathrm{XV}$, 343). Sobre esse mesmo assunto, visitando o país dos ciclopes, Odisseu se admira da ausência de espírito comunitário entre eles, vivendo isolados, destituídos de leis e sem se importar com o bem estar dos vizinhos ${ }^{\text {1xii }}$. Evidentemente o navegante demonstra surpresa com a vida de outros povos que não são homens públicos, não se preocupam com o outro, uma situação diferente da que detém a maioria dos países, inclusive o seu. 
Recorde-se o fato de que ele está contando sobre os ciclopes no banquete do rei Alcínoo, que, ao que indica o texto, primava pela ordem e respeito em seu governo. Portanto, temos nessa reflexão uma pré-noção de cidadania entrevista também na frase: "a nada se pode aspirar de mais alto / que ver a paz entre o povo e a alegria no rosto de todos" ( $O d$, IX, v. 5-6). Retornando, o rei de Ítaca se farta de alegria, beijando o solo de sua pátria e lutará pelos seus domínios, tendo o filho como aliado. Mesmo ausente, Odisseu demonstrara ser bom homem, que prezava a família e sentia saudade dos seus. Retornando a Ítaca, ele chora ao abraçar o filho, também emocionado, depois, procura o pai, enchendo-se de emoção ao revê-lo e, após ouvir do idoso homem os lamentos sobre o filho amado e ausente, expressa efusivamente a saudade e a afeição. À ama Euricléia, Eumeu e outros servos, Odisseu se mostra, também, afetivo, demonstrando o valor que todo clã familiar - aí envolvendo os escravos - detinha em seu coração. Todavia, o encontro com Penélope revela o quanto Odisseu amava e respeitava sua esposa e os laços matrimoniais que os uniam, embora tenha recebido de Agamenon, no Hades, conselhos estranhos ao seu modo de proceder. O rei morto pela traição da esposa advertira a que nunca se mostrasse bondoso para com a consorte, bem como nunca the

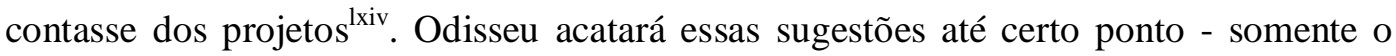
fazendo para que uma emocionada Penélope não atrapalhasse, com sua emoção, a vingança cabal a ser perpetrada contra os invasores de seu palácio. Chegando o momento oportuno, o herói se dá a conhecer e, depois de identificado, entregam-se ambos a prazerosos momentos íntimos. Depois dos amores, agradável e extenso diálogo se instaura, a esposa contando seus pesares, e em seguida, o marido narrando as mágoas e surpresas da viagem, sem nada esconder. O narrador dá conta da fascinação que as narrativas exercem na ouvinte. Depois de encetar a longa história dos vinte anos de aventuras, vem um detalhe: a exigência de Tirésias quanto ao futuro. Odisseu bem que 
gostaria de ocultar do cônjuge a necessidade de mais uma jornada, com todos os riscos que ela traria, mas, por insistência da mulher, acaba lhe revelando as determinações do vate, censurando, entretanto, sua ânsia de conhecimento do porvir. Penélope é chamada "sensata" e "muito sensata" em toda a narrativa, sendo "louca" apenas por desejar mais conhecimento sobre algo que nunca se convém saber, dadas as chances de ser contrário ao que se espera. Apesar de tudo, ressalte-se a ênfase na boa comunicação entre esposos que se apresenta na Odisséia. O belo momento amoroso de Odisseu e Penélope faz-se coroado pelo diálogo e o narrador inclui a relevante informação de que o marido nada oculta de sua esposa.

Enéias também é dedicado aos deuses, desde a Ilíadal deuses imortais" (Il, XX, v. 349). O poema de Virgílio enfatizará ao máximo essa

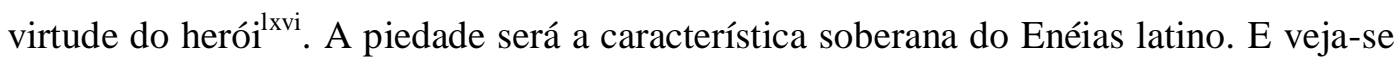
como o narrador de Eneida introduz seu herói:

"Eu canto as armas e o barão primeiro Que, prófugo de Tróia por destino, À Itália e de Lavínio às praias veio (...) Um barão da piedade assinalado" (En, I, v. 1-3, 16).

Na Eneida, o herói lamentará sua Tróia devastada e tentará lutar por ela, mesmo em face da morte, pois seria uma honra entregar a vida pela pátria. Todavia, seguindo a ordem dos deuses, batalhará por uma nova pátria, uma espécie de refundação de sua Tróia. Em relação à família, Enéias será um homem em eterna disposição para proteger os seus, bastando lembrar sua atitude para com o pai, pondo-o cuidadosamente às costas; a gentil atenção para com o filho, cuja mão permanece segura na do pai; e a esposa, que é alertada a que não se afastasse dele: 
"Sus, meu pai, eu te ajudo, às nossas costas

Sobe-te, ó caro, não me agrava o peso

Em sucesso qualquer, teremos ambos

A mesma salvação, comum perigo.

Ladeie-me o filhinho, e atrás Creúsa

Não se afaste de mim. (...)"

(En, II, v. 830-5).

Mas, sabemos do restante da história: a mulher se vai para junto da deusa Cibele;

o pai falece no transcorrer das viagens; a segunda esposa lhe é proibida pelos deuses e ele precisa guerrear por uma noiva que não o aceitará com sorrisos. Assim mesmo, entristecido e lamentoso, Enéias segue seu destino de formar uma família segundo a vontade dos deuses, iniciando um novo reino através do filho Ascânio. A dedicação extrema de Enéias à família não abrangerá a ligação com Dido, embora seja esse um relacionamento intenso para os envolvidos. O casamento de ambos será pautado por diversidade de intenções e problemas na comunicação. Vejamos como o Enéias virgiliano se mostra no âmbito conjugal. Primeiramente, Enéias se demonstrará apaixonado [sem que as setas de Cupido o tenham atingido, como fizeram com Dido...] e, vestido do rico manto feito pela esposa a ainda trazendo a espada que essa lhe dera, trabalhará alegremente na construção da cidade de Cartago, assessorando a consorte. Até aí, um belo quadro familiar se apresenta. Depois da visita de advertência de Mercúrio, um acovardado Enéias se mostra, a derreter-se de medo ante a expectativa de falar francamente com Dido sobre as ordens divinas. Buscando a falsidade, Enéias tenta elaborar estratagema para falar com a mulher, mas a esposa percebe o ardil e muito se magoa $^{\text {lxvii }}$. Ante a dor da jovem rainha, Enéias se cala. O diálogo não mais existiria para o casal. Os ditames divinos estavam em primeiro lugar em sua vida, apesar de haver despendido um tempo em tranqüilo esquecimento de seus objetivos, tão boa era a companhia feminina. Resgatado o senso de missão, o olhar se fixa no alvo a ser alcançado - fundação de Roma -, porém, o coração sofre e ele tenta ocultar essa dor. 
Enéias, finalmente, conseguirá falar sinceramente quanto aos mais profundos sentimentos e dirá: "Com saudade sempre hei de lembrar-me" (En, IV, v. 491), arrematando que não era por gosto seu que buscava outros horizontes. Irada, Dido lançar-lhe-á em rosto palavras ásperas e Enéias, novamente, se calará porque o coração se dividia entre "o receio de falar e o muito / Que a dizer se dispunha" (En, IV, v. 580). Assim, um grande descompasso se instaura na devoção de Enéias em relação à família e, nesse ponto, chegamos aos princípios norteadores da família romana. O amor, nos tempos de Virgílio, era menosprezado, condenado mesmo, por se tratar de um descontrole emocional, cujo efeito era a morte. Os casamentos eram meros arranjos entre as famílias, sendo a mulher apenas uma produtora de herdeiros, havendo, evidentemente, casos de matrimônios cuja tônica era o afeto entre os esposos que desenvolviam o sentimento após as núpcias ${ }^{\text {lxviii }}$. Esses casos, porém, era exceção à regra. O epicurista Virgílio, cujas palavras poéticas fazem apologia de suas crenças no equilíbrio, temperança, procura da paz e serenidade, ele mesmo avesso às expansões de espírito, no que diz respeito às relações sociais ${ }^{\text {lxix }}$, defenderá o casamento ideal como o que acontecerá entre Enéias e Lavínia - como sendo uma aliança de interesses políticos. Enfim, do casamento arranjado entre Lavínia e Enéias, nada mais saberemos, a não ser que será o germe fundador do povo italiano.

Com referência à piedade ligada ao sentimento de devoção e obediência aos deuses, não vemos um Bernardo religioso, prestando homenagens ou sacrifícios aos deuses. Ao contrário, o barraqueiro às vezes duvida da interferência sobrenatural em sua vida ou na de qualquer ser humano, expressando questionamentos quanto ao papel da humanidade no Universo. À esposa dirá: "Muito difícil a gente se convencer de que está sozinho, que só pode mesmo contar com as próprias forças" (OFP, 256) e indagará a si 
mesmo a justificativa para a existência humana e a possível orientação nas ações: "Por que se vem, por que se é posto no mundo? E desde que se vem, como agir?" $(\mathrm{OFP}, 270)$

Em $O$ fiel e a pedra, a política não é diretamente mencionada, mas percebemos Bernardo como cidadão preocupado com o bem estar dos outros, sem transgredir as leis de sua comunidade, sendo respeitado pelos princípios morais elevados. Todos o respeitam por ser melhor do que eles, segundo Miguel Benício - na verdade, as pessoas o respeitam por ter se mostrado contra as desonestidades do fiscal com o qual trabalhava - homem conhecido pelo caráter suspeitoso. O próprio Miguel lhe oferecerá trabalho em razão de sua probidade. Bindinho demonstrará amizade e consideração - o único a emprestar dinheiro na dificuldade. O ex-empregado Antônio Chá testemunhará das qualidades do antigo patrão e se disporá a segui-lo para a fazenda. No Surrão, Bernardo tratará a todos com respeito e atenderá igualmente a mulher que é surrada pelo amásio, a mãe cujo filho lhe rouba os centavos, o vigia e sua mulher, os demais funcionários do engenho. E quando Miguel sugerir algo contra as leis da comunidade e de seu país - e mais ainda: de sua consciência - Bernardo não concordará. Hutá Vilarim será seu novo sócio, uma demonstração de que o íntegro motorista [veja-se sua auto-avaliação na conversa que tem com Bernardo, ao levar o casal para o Engenho] o escolherá por se enquadrar nos requisitos para uma boa parceria empresarial.

Pensando-se na valorização da família e da terra natal no romance osmaniano, Bernardo fica dividido entre a liberdade das estradas, uma vida sem fronteiras e a rotina da vida familiar, as atividades cerceadas pelo espaço físico; mas tenderá a ligar-se às raízes. Justificando a Antônio o motivo de sua opção sedentária, Bernardo diz que Teresa é a pedra que o retém: "Não havia Teresa - pedra, um peso fixando a vida (...)" (OFP, 31). Interessante é a metáfora, já que, ao cruzar o rio Tapacurá, aquele episódio que o marcara tão profundamente a ponto de sonhar com o momento nas fases mais 
difíceis da vida segurara suas vestes com uma pedra. A "roupa", tão importante para cobrir o físico do adolescente, fazendo-se uma espécie de extensão do próprio corpo, deveria, necessariamente, estar disponível por ocasião da travessia. A pedra funcionava, por assim dizer, como eficaz âncora, protegendo a "segunda pele", impedindo-a de ser levada para longe, pelos ventos - ou seja, em um aspecto simbólico, a pedra impossibilitava a tragédia da perda de identidade. Enfim, homem feito, a outra "pedra" lhe fixava os vôos. A prima-esposa o arraigava às origens familiares. E mesmo antes de tomar a decisão de se casar, as viagens não eram uma fuga definitiva do ambiente em que vivia os seus - como ocorrera com o irmão, partindo para nunca mais retornar, a despeito das promessas de visitar a mãe: Bernardo sempre retornará ao seu ancoradouro - o que se exemplifica nas suas próprias palavras: “Toda viagem tem o seu regresso (...)" (OFP, 49). Nesses hiatos, os regressos das viagens, Bernardo participaria dos encontros familiares, devotaria atenção ao sobrinho e cultivaria a amizade com a prima, sentimento que se desenvolveria para um estágio mais íntimo, levando-o ao matrimônio. Apesar de dedicado à mãe, ao sobrinho e à esposa, Bernardo nunca se apazigua quanto às decisões tomadas em prol do conjunto familiar. Ele se culpa, quase durante toda a história, seja por haver abandonado o emprego e, conseqüentemente chegar ao ponto de não conseguir tratar a doença do filho que falece; seja por levar Teresa a viver no Surrão, sem conforto e longe dos seus: "Você tem sofrido o que não devia sofrer tornou Bernardo com desânimo" (OFP, 191). E sentirá um medo misturado com angústia e certa impotência pensando no futuro do filho que Teresa carrega no ventre, pensando que certas pessoas deviam permanecer solitárias: "Há gente neste mundo que devia se agüentar sozinho" (OFP, 189). Todavia, Bernardo, apesar de extremamente dedicado à esposa, não se revela como um parceiro comunicativo. De certa forma, o conselho de Agamenon a Odisseu [não confiar segredos à esposa], e a bela, mas triste 
história de Enéias e Dido faz-nos recordar da dificuldade de comunicação entre Bernardo e Teresa e, particularmente, de o primeiro fazer confidências à esposa. Seria a síndrome do "macho de coragem", como canta a estrofe da canção que antecede o romance, a atrapalhar o diálogo? Seria a noção de macheza no Brasil dos anos 1930, época na qual se baseia o autor para conceber o tempo de seu romance, a razão que impedia o extravasamento de afeições ou sentimentos íntimos? Com a sequiência de ocorrências perturbadoras, Bernardo revelará suas travas comunicativas com Teresa, que, diferentemente de Dido, convenhamos, não é temperamental ou belicosa. Embora nunca use de artifícios, porém, Bernardo tentará fugir do olhar investigativo da esposa, disfarçará sua angústia e, deliberadamente, lhe ocultará certos fatos ${ }^{\mathrm{lxx}}$, como por ocasião da morte de Miguel, quando lhe contará as impressões do fatídico dia, deixando de lado determinados elementos: "Ocultou o diálogo infeliz com João Cardoso, sua convicção de que Nestor assassinara o irmão (...), as alusões mansamente ferinas de Suzana e o modo como Ascânio perguntara, ao vê-lo, se agora Teresa ia voltar" (OFP, 98). Depois da visita de Nestor, quando esse combina vir buscar o gado dos herdeiros, Bernardo, que cogitara levemente fazer olhos de mercador para o caso, evitará a cônjuge por se sentir constrangido diante de seu olhar acusador: "Confessou a si mesmo que evitava a presença de Teresa. Seria intolerável ir para a sala, balançar-se na rede, esperar a mulher; e saber, quando ela viesse, como estava tenso de compaixão e censura o seu silêncio" (OFP, 108). Tentará dominar os traços fisionômicos para que esses não o denunciem: “Impunha ao rosto uma expressão serena” (OFP, 231).

Como o casal de Eneida, Bernardo e Teresa se gostavam muito. O sentimento que os unia era pautado por respeito e solidariedade. A seu modo - silenciosos e introspectivos - eles apreciavam a companhia um do outro e conversavam sobre o diaa-dia e os planos futuros. Teresa se lembrava do que vira no marido à época do pedido 
de casamento: "E encontrara na solidez daquele homem, em seus cuidados para com ela, em sua maneira de ser e de viver, qualquer coisa de áspero e de amplo, que alegrava sua alma" (OFP, 144). Embora fosse a mulher quem lhe dirigia expressões de amor, Bernardo pensaria sobre a esposa que ela era a pessoa a quem mais amava (OFP, 5). Como no caso de Enéias e Dido, as núpcias haviam sido, de certa forma, ilegais, em termos de consentimento da mãe da noiva, embora legais nos termos jurídicos. Assim como o troiano, Bernardo ajudara a esposa a construir uma vida matrimonial harmoniosa - sua cidade-reino - vida essa que, apesar de pobre, era dotada de pequenas alegrias e o mínimo de bem-estar (manutenção da casa, plantação de produtos para o alimento, criação de animais, também para o mesmo fim, reparos no moinho). Ele orientara Antônio na construção das cercas para o jardim de Teresa, mandara afofar os canteiros; enfim, promovera condições para que ela executasse a rotina doméstica a contento. Mas a imensa culpa não o deixa, uma referência, talvez, à culpa eterna de Enéias $^{\mathrm{lxxi}}$ por haver deixado sua Dido. O amor de Bernardo por Teresa é um amor tenso, repleto de culpa advindo do agudo senso de responsabilidade. Como a maioria dos homens brasileiros dos anos 30, Bernardo sentia que precisava proteger a esposa e conceder-lhe os bens necessários ao seu conforto. Se possível oferecer adereços e vestes caras, assim como outros luxos que a mulher bem o merecia. Essa noção do homem como protetor aparece logo no início, quando o casal presencia a morte do filho e Bernardo, de certa maneira, critica a esposa por ter concordado com a decisão que ele tivera, de abandonar o emprego. Mais adiante, o esposo de Teresa se agoniaria ante a vida que oferece à esposa: “- Teresa... Será que fiz bem? (...) Se nos dermos mal, quero que você não me culpe. Você não é para uma vida assim. Mas isso não vai ser definitivo, é um tempo, depois vamos embora" (OFP, 45). Quanto ao choro sentido de Enéias, ao se saber ofensor da mulher amada, essa atitude, é uma das poucas que não é 
imitada por Bernardo. Uma frase que ele diz ao sobrinho, mesmo em ambiente de terna brincadeira, mas que denota a preferência em não demonstrar fraqueza de sentimentos: "Bernardo entrara, tomara-o [a Ascânio] nos braços, jogara-o para cima, dissera que homem não chora" (OFP, 262). Esse mesmo homem que preconiza o não derramamento de lágrimas "masculinas" irá, com muito sofrimento, abrir-se com a esposa e rogar-lhe proteção: "Quem de nós é mais frágil?" (OFP, 250). E esse amor profundo já se mostrara no início da narrativa, na cena que abre o texto, ou seja, a morte do filho de ambos. Depois de ouvir da mulher o pedido para que não a acusasse, já que ambos haviam anuído à resolução tomada, Bernardo pensa: “A quem sobre a terra, a quem no mundo quisera proteger como a Teresa? A quem mais fortemente amara? E quem, mais do que ela, merecia a sua proteção, o seu querer, seu zelo?" (OFP, 5). Entretanto, esse amor permanecerá. Não da mesma maneira como se desenhava na juventude do casal. Depois dos quase vinte e cinco anos após o balanço fatídico, o que restará? O narrador diz que em oposição do morno sentimento de Ascânio pela esposa, o amor de Bernardo por Teresa aparentemente não se transformará - a ação do tempo há de conferir-lhe certa dignidade, as palavras do narrador nos fazendo lembrar o casal protagonista de Odisséia, cujo amor resistiria às tempestades da vida, aos mares revoltos, e envelheceria assumindo ares majestosos:

"Já o amor de Bernardo por Teresa, não se pode dizer que haja verdadeiramente mudado. Sofre a ação do tempo, sim; ação, todavia, semelhante à que o mesmo tempo exerce sobre uma escultura, que parece conquistar, com os anos, uma espiritualidade mais alta" (OFP, 313).

Sobre o amor, especificamente

Os heróis recortados das epopéias citadas caracterizam-se pela atitude gentil em relação à mulher amada. Aquiles, mesmo tendo conquistado Briseida sob o signo do poder e violência, dedica-lhe especial deferência. Odisseu age de igual forma em 
relação a Penélope, atribuindo-lhe tanto valor que a sobrepujava às deusas. Enéias, embora fosse obrigada a abandonar Dido, demonstra-se encantado por ela, cooperando com seus propósitos que incluíam a construção de Cartago e lamentando-se, depois, com muita dor, por ter que abrir mão de sua querida esposa. Como vimos, em pinceladas esparsas, Bernardo também se revelava delicado e atencioso para com Teresa, demonstrando preocupação constante (e até excessiva) com seu bem-estar, oferecendo-lhe pequenos mimos (as revistas femininas, os sapatos). E a reação das mulheres, as chamadas heroínas cujo nome entrelaça-se poeticamente ao dos heróis abordados? Briseida, Penélope e Dido deixaram-se fascinar pelo caráter de seus homens. Elas os admiravam, preferindo a vida ao lado deles a qualquer outra hipótese, como se vê no caso de Briseida, entristecida ao ser levada da tenda de Aquiles, a mando de Agamenon; no caso de Penélope, chorosa por estar longe do marido e também em relação a Dido, matando-se por não suportar a dor da ausência de Enéias. Teresa também optara em viver ao lado de Bernardo em todas as situações. A adesão ao projeto de vida do esposo e a constatação da importância do homem amado para sua própria existência transparece no diálogo com Suzana. Defendendo sua relação de amor, a jovem esposa diz: "Eu sou feliz. (...) - A senhora sabe que eu não estou mentindo. (...) Saiba que não fiz um casamento de órfã. (...) Quero que a senhora nunca mais se esqueça disto" (OFP, 34). E sobre o significado do marido na sua vida, acrescenta: “Eu tenho padecido - vou negar? Mas Bernardo é as minhas raízes. Sem ele, com outro homem, que seria eu? Hein? Que seria eu?" (OFP, 35).

Pelo caráter de Bernardo é que o amor de Teresa é despertado e enraíza-se profundamente, fazendo-a similar à Briseida, Penélope e Dido, cuja fidelidade ao amor permanece mais valiosa do que a própria vida. Enquanto Bernardo se culpa por não poder oferecer à esposa a vida confortável que ela bem mereceria, Teresa procura 
conscientizá-lo de que o amor que ela lhe dedica independe de bens materiais. Para cristalizar essa atitude, Teresa perfaz um juramento, belíssima página em $O$ fiel e a pedra, cujo lirismo toca de forma especial os leitores. O juramento aparece no capítulo XXXV e vejamos como se dá. Após as vicissitudes sofridas no Surrão e em função da atitude da esposa diante das dificuldades, Bernardo observa atentamente a esposa, constatando na aparência de Teresa a inexorável passagem do tempo acrescida às provações:

"Olhou as mãos de Teresa, que manejavam com grave paciência a agulhas e as linhas de cor. Lembrava-se como eram; mais claras, mais suaves do que hoje, naqueles anos ainda próximos e que já pareciam tão longe, em que ela acariciava o seu braço, com a ignorância e o ardor de sua virgindade ..." (OFP, 189).

Ele pensa com tristeza que não pudera oferecer uma vida serena e adequada ao nível econômico da mulher. Ao contrário, somente medo e aflição fizeram parte de sua rotina. E diz: "O homem que você aceitou não é o homem que você tem. Eu não possuía nada, mas você tinha fé em mim. E hoje?" (OFP, 191). Em vista da insegurança do marido em entender seus reais sentimentos, Teresa, que sufocara as expressões de vívido amor, explode em declarações de um afeto quase inexprimíveis em palavras. Essas novas juras se fazem repletas de maturidade, porque ambos vivenciaram tristeza e dor; embora nunca tivessem deixado de amar um ao outro. Teresa é a parte do casal que expressa em palavras essa aliança incondicional. Ela diz, explicitamente, que não deixara de amar Bernardo em nenhum instante na trajetória dificultosa de suas vidas, mas o amava muito mais, em virtude de se sentir una a ele na jornada que ambos empreendiam:

"Há oito anos eu lhe jurei amizade. Mas aquele juramento era só um desejo e um propósito. $\mathrm{O}$ juramento que faço agora vale mais e tem mais 
peso, porque eu sei o que digo, eu não conheço apenas a esperança, mas também o sofrimento, o perigo, a solidão e a morte" (OFP, 193).

Diante do confronto de emoções, Teresa refaz o compromisso de amor: "Hei de amá-lo sempre, sempre, com todo o amor que está em mim e de que sou capaz" (OFP, 193). Embora o juramento, aparentemente mostre-se romântico e destoante do tom épico das epopéias, perceberemos que não fugirá ao arcabouço epopéico. Juramentos são pontos marcantes na Odisséia, por exemplo. Ao se preparar para a viagem de retorno, Odisseu pedirá à ninfa Calipso que lhe faça um juramento prometendo nenhum mal fazer ao ex-hóspede durante sua viagem de retorno ao lar. Odisseu desconfiará da magnanimidade da ardorosa ninfa que o desejava como eterno esposo e exigirá prova dos reais intentos da bela divindade:"Nunca entrarei em jangada, se for contra tua vontade, / a menos que te resolvas, ó deusa, a fazer juramento / de que não tens intenção de outros males, agora, causar-me" (Od, V, 177-9). E a ninfa atenderá ao pedido, formulando as palavras juramentais:

\footnotetext{
"Pois tome a Terra ciência, bem como o Céu vasto de cima e a água do Estige, que se precipita - esta é a jura mais alta e mais terrível de todos os deuses bem-aventurados de que não tenho intenção de outros males, agora, causar-te. Mas o que penso e proponho fazeres é como se eu própria me propusesse, se acaso me visse em igual conjuntura" $($ Od, V, 184-9).
}

Nesse juramento, Calipso deixará claro que proporá à viagem apenas o que ela mesma faria, ou seja, generosamente se colocando no lugar do outro, para ajudá-lo de forma plena. Calipso demonstra assim um espírito capaz de abrir mão de seu bem estar em prol do próximo, imiscuindo ao amor, a justiça. Se o belo Odisseu não podia ser seu esposo, que se fosse e vivesse feliz com outra pessoa: "Eqüitativa é minha alma e à 
justiça inclinada; no peito / não se me aninha um espírito férreo, senão compassivo" $(O d, \mathrm{~V}, 190-1)$.

A Odisséia parece abordar a complexidade do amor, como um sentimento que pode envolver o espírito perdoador, a generosidade, um amor que não oprime, nem prende em cadeias. Esse tipo de amor estará sempre ligado à fidelidade, o que expressa o juramento. Novamente amor e confiança imbricados em um juramento ocorre entre Circe e Odisseu: “Ora repõe na bainha essa espada, e ambos nós, depois disso, / para o meu leito subamos, porque ambos, no amor enlaçados / dessa maneira, no leito tenhamos confiança recíproca" ( $O d, \mathrm{X}, 333-5)$. Sabendo que não havia possibilidade de existência diversa daquela situação, e, advertido anteriormente por Hermes sobre a necessidade de acatar a proposta, o herói capitula, mas exige um comprometimento legal: "Não, jamais hei de mostrar-me disposto a subir ao teu leito, / a menos que te disponhas, ó deusa, a fazer uma jura / de que nenhuma outra insídia planejas, de fato, em meu dano" ( $O d, \quad \mathrm{X}, 342-4)$. Circe efetua um juramento solene e Odisseu se torna participante de sua vida, intimamente [afinal, não haveria outra opção]: "Tendo ela, pois, completado as palavras da fórmula sacra, / fui para o leito de Circe (...)" (Od, X, 346-7).

Enéias e Dido perfazem juras num consórcio oficializado pela Terra e a "prónuba Juno" (En IV, 245-6), tendo o Ar como testemunha. O juramento remetia ao costume dos romanos de encerrar suas transações com esse evento ${ }^{\text {lxii }}$. Na epopéia virgiliana, porém, Enéias rompe com o concerto que o poeta denomina falso: "De ocultar seu amor já não cogita / A malfadada Elisa: casamento / Lhe chama e com tal nome a culpa encobre" (En, V, 251-3). Dido reclamará a validade da simbologia das mãos: “(...) Nem o amor nosso, / Nem a mão que me deste (...) / Te detém?” (En, IV, 449). Por romper o juramento e causar dor e morte à amada, Enéias se culpará - uma 
culpa eterna. O que podemos concluir? Dido foi fiel a Enéias em uma aliança caracterizada pelo juramento, mas o consórcio não era autorizado pelo Destino, segundo o poeta. A grande dor de Dido adveio justamente pelo que ela entendera como quebra de confiança da parte de Enéias, desconsiderando os ditames divinos. Esse juramento aparece no capítulo XXXV, o qual é antecedido pela citação do Sermão do Mandato, de Vieira. Observemos as belas palavras desse sermão, após a primeira frase do exórdio: "Forte amor. 'Não novo, porque deixasse de amar alguma hora, mas porque era pouco o que dantes prometera, em comparação do muito que hoje amava.' (Vieira, Sermão do Mandato.)" (OFP, 189) $)^{\text {lxiii }}$. Vieira aqui se refere ao juramento feito por Davi a Jônatas, o filho do rei (e ferrenho adversário de Davi) em proteger os descendentes do amigo quando subisse ao trono. É interessante observar que o conceito central da aliança feita por Jônatas e Davi, conforme o relato bíblico é a noção de fidelidade. Osman Lins impressiona-se com a aliança feita por Jônatas e Davi. Essa imagem é a escolhida para retratar o novo concerto de amor feito por Teresa a Bernardo. O excerto do sermão remetendo à narrativa bíblica - coroa o momento mais idílico do casal protagonista de $O$ fiel e a pedra. Retoma-se, desse modo, o conceito de fides - confiança, garantia da palavra empenhada, fidelidade decorrente de um juramento - acariciado em Odisséia e na Eneida. O diálogo com as epopéias, nesse quesito, faz-se, não apenas mediante o juramento explícito enunciado por Teresa, mas com a postura do casal no relacionamento mútuo como um todo. Teresa é fiel a Bernardo, não apenas no aspecto físico, mas emocional e espiritual e isso se nota do início ao fim da narrativa. Ela apóia o esposo na decisão de sair do emprego, não o acusa da morte do filho, defende-o junto a mãe, concorda com a mudança para a zona rural, permanece ao lado do marido no enfrentamento a Nestor. Teresa demonstra orgulhar-se da retidão de Bernardo e somente uma vez, como já vimos, lhe faz uma censura muda. É a fidelidade de Teresa às 
mínimas ações do dia-a-dia da família que faz com que Bernardo reassuma seu norte no que diz respeito ao que seria o correto, como ao fazer a cama, estendendo o lençol, sem nenhuma ruga.

No entanto, o "macho de coragem, valente e sem pabulagem" considerará ser muito difícil aceitar o amor incondicional advindo da mulher amada. Bernardo sofrerá intensamente entre o desejo de partilhar com a esposa os seus reais temores e os acontecimentos que motivam tal angústia, e o senso de proteção: "Eu não devo, não devo dizer" (OFP, 250). Ele sentia que, como marido, era quem deveria estender as asas por sobre a família, provendo-lhe todo o conforto e nada deixando ocorrer de mal: "Era o silêncio dele que a protegia do terror" (OFP, 231). E se amargurava, pois sabia que não estava mais suportando arcar com o peso dos problemas, sozinho: "Sabendo que não tardaria a fraquejar, ceder, trazê-la para o sofrimento onde decidira ficar só. Ela, a quem devia proteger" (OFP, 250). Mais à frente, enfim... Bernardo rompe as amarras da comunicação e conta à mulher sobre os tiros na estrada - e a reação da esposa é exatamente a que o marido esperava, e tentava evitar: Teresa chora, corroborando a frase de Bernardo, dita a si mesmo, em outra ocasião: "Como viera acrescentar-se a ele aquela mulher frágil, de que maneira profunda e dolorosa!" (OFP, 267). No entanto, era preciso que assim se desse, já que a esposa, diferente dele, sensível e emotiva, reagiria a seu modo. Estando ambos casados e formando "uma só carne", como ele mesmo se lembra, fazendo referência ao primeiro casal edênico e a um conselho do rei Salomão: "Uma só carne. E um só destino. Esposos. Os dois unidos, enlaçados, fibras de uma corda" (OFP, 249) ${ }^{\text {lxxiv }}$, teria que ouvir o pranto e conviver com os terrores da mulher. Afinal, eles formavam uma equipe.

\section{Repúdio à hipocrisia}


Parece ser comum aos heróis das epopéias a integridade de caráter, o que os leva a repudiar a hipocrisia. Aquiles, por exemplo, é integro em seus princípios e não labora com sutilezas ou dissimulação. Contra-argumentando o discurso de Odisseu, que, na embaixada lhe acena com as benesses de voltar à guerra, ele diz odiar as pessoas de falar ambíguo, dissimulado propositalmente: "Ouve, Laertíade, poliastucioso: sem meios termos, claro, direi quanto penso e farei, / (...) Como às portas / do Hades, detesto quem fala uma coisa e esconde / outra na mente (...)" (Il, IX, v. 319-3). A hipocrisia está ligada à mentira, e Odisseu, embora viva armando situações imaginativas, fazendo-se passar por outrem ou inventando história acerca de si mesmo, afirma sentir aversão ao hábito de se disseminar mentiras sobre os outros - e aí a diferença entre a narrativa com intenção "positiva” e a dotada de razões pérfidas: “(...) sinto entranhável / ódio a quem cede à miséria exterior e inverdades espalha" (Od, XIV, v. 156-7). Enéias parece pecar nesse quesito, sendo não muito franco ou leal com sua Dido.

A par da fidelidade aos princípios, ao agudo senso do que é moral, das noções de cidadania - tão comentadas, até aqui, em nosso trabalho - Bernardo se demonstra, durante toda a narrativa, como alguém que é sincero e coerente em todas as suas ações ou palavras. Não agrada aos outros com a finalidade de conseguir favores, nem expressa falsos sentimentos - é o primeiro, e muitas vezes o único, a levantar a voz para apontar o erro, como no caso da morte de Miguel em que denuncia o crime. Outro episódio que demonstra a aversão de Bernardo por palavras falsas ocorre quando o advogado Teles, o visita para obter informações acerca do gado de Creusa e herdeiros. O jovem profissional, em dado momento o chama de "amigo" e Bernardo incomoda-se interiormente com o vocábulo, a seu ver, indevido. O narrador diz: "Aquele termo ‘amigo', tão levianamente empregado, irritara-o" (OFP, 114). Esse incômodo se liga à inteireza de sentimentos, cuja parca expressão é acompanhada de uma seriedade ímpar. 
No episódio em que Nestor o assedia com um cumprimento falso: “- Tudo velho?"

(OFP, p. 179), Bernardo se nega a empregar um tom falso, apenas para seguir as normas sociais. Aliás, o barraqueiro não pronuncia nenhuma resposta ao cumprimento. De outra feita, na assustadora noite em que o bando de Ubaldo bate à porta do armazém, com a expressão amenizadora: “- Aqui é de paz”, enunciada por um dos participantes do grupo. Bernardo retruca a frase, comentando, corajosa e francamente: “- É de paz querer botar a porta abaixo?" (OFP, p. 183)

O esposo de Teresa se negava a compactuar com a pouca relevância das palavras. E o discurso de Nestor, em outra ocasião, enunciado em voz melíflua e ameaçadora sob um tom bajulatório, provoca mais ainda a ira de Bernardo, como conta o narrador:

"[Nestor] Falou mais. A ira de Bernardo inchava. Estava bem atento às claras ameaças que se disfarçavam naqueles protestos de amizade e dominava as imprecações que ferviam em sua boca. (...) Parecia aguardar, no horizonte, o aparecimento de um inimigo mortal, a quem odiasse por se ocultar de sua fúria, e o ódio crescendo nessa espera. Já não ouvia palavras, a voz de Nestor era um sussurro longínquo. Suas mãos latejaram; nas palmas, nos dedos, como que se formavam - ainda presos - grande ventos coléricos. Seus pulsos doíam e ele perguntou a si mesmo, com espanto, que ato misterioso e horrível se gerava em seu espírito. Havia uma súplica nesta indagação - ele desejava conjurar o ato que suas mãos anunciavam" (OFP, 198).

E por fim [embora haja mais dezenas de exemplos], no dia do fatídico balanço, Nestor, rodeado por capangas, perguntará em tom falsamente leve, quais seria as "novidades”, ao que Bernardo responderia: “ - Você não veio fazer nenhum negócio. Veio me atacar" (OFP, p. 290).

Efetivamente, Bernardo não dava lugar a conversas fortuitas ou simplesmente amenas, dessas que se fazem sem nenhuma convicção: "era um homem de contadas palavras” (OFP, 9). Bernardo dirá a Miguel, tentando fazê-lo crer que a esposa poderia 
ser vítima das línguas ferinas, tão somente: "Não será boato, falação desse povo?" (OFP, p. 71); e demonstrará ojeriza pelo falatório de Nestor: "Nestor é como se tivesse muitas bocas, no peito, nas mãos, prontas a morder e todas venenosas" (OFP, p. 104). Portanto, estamos diante de um protagonista que não usa de "pabulagem", como bem entoa o cantor. Bernardo enuncia suas "contadas palavras" com a segurança de que elas refletem apenas e tão somente o que ele deseja dizer. Palavras, para esse homem simples do sertão, não existem para se tornarem peças de um jogo qualquer. É isso que transparece ao longo do romance.

\section{Bondade}

Bondade, aptidão para aconselhar, generosidade, são atributos de alguns dos heróis. Todavia, difícil é aceitar o fato de que Aquiles, o herói que mais carrega em si o estatuto do másculo guerreiro, também tenha apresentado em seu caráter esboços de brandos sentimentos. Mas tal ocorre em várias oportunidades. Uma delas é a postura do herói diante dos que estão sob seu comando. Um dos exemplos ocorre por ocasião da grande peste que se instaura no campo grego, após a oração de Crises e, movido pela preocupação (essa, conforme o narrador, inspirada divinamente), convoca a ágora [notese que não é o rei quem assim age] para que todos concordem em buscar auxílio divino $^{\mathrm{lxxv}}$. Em seguida, Aquiles demonstra compaixão pelos oprimidos ao prometer a defesa e proteção do velho áugure, Calcas Testorides, diante de Agamenon, ao esse enunciar a causa da ira divina e das mortes gregas. De outra feita, Aquiles compara a motivação interna em proteger os aqueus aos sentimentos maternais. Causa espanto e agradável surpresa ler os versos seguintes:

"Como a ave-mãe leva ao filhote implume o que acha para comer e fica à míngua, assim também 
privado do repouso de Hipnos, muitas noites

tresnoitei, após dias a fio de sanguinosas

pelejas (...)"

(Il, IX, 323-7).

Outra reação amena de Aquiles é a complacência na reação efetiva - não a do primeiro impulso - frente a decisão do rei em lhe tirar a cativa. Apesar de vociferar contra Agamenon e tentar matá-lo no início, suaviza suas atitudes e não toma mais nenhuma medida drástica para impedir a ação. O mais audaz dos guerreiros, diante de quem as cidades tremiam, não faz mal aos temerosos, ou, como diz o tradutor, “constrangidos" (Il, I, 319,32) arautos, Euríbato e Taltíbio, incumbidos da funesta missão de buscar a preciosa Briseida. Ao chegarem ante as tendas de Aquiles, ambos os mensageiros quedam-se paralisados de terror diante do famoso guerreiro e, embora sem se alegrar com a presença dos que vão lhe arrancar o bem mais caro, é com delicadeza ímpar que Aquiles lhes dirige palavra: "Arautos, vos saúdo, (...) / Aqui chegai mais perto. Não, / de nada vos acuso. A culpa é de Agamenon” (Il, I, 334-6). Em outra ocasião, ao receber a embaixada intercessora, Aquiles se mostra bastante afável: "Salve! Eis aqui guerreiros amigos! Algum / motivo urgente, grave, é que vos traz a mim! / Ainda que irado, sois-me, entre os Gregos, caríssimo!" (Il, I, 197-9). Uma espécie de cortesia - ou mesmo, prenúncio de atitude ética - aparece no elogio que faz aos troianos. Depois de ouvir o anúncio de que perderia a esposa para Agamenon, Aquiles, corajosamente, assume o fato de que nada tem contra os adversários troianos, louvandolhes as qualidades: “Até aqui não vim guerrear os Troianos, / Lanceiros excelentes. Não me queixo deles. / A mim não me roubaram gado, nem cavalos” (Il, I, 152-4). Por mais estranho que possa parecer, Aquiles também demonstra compaixão pelo rei de Tróia, quando esse vai até ele rogar pelo corpo do filho. Estranho, porque Aquiles fizera o que fizera com o cadáver - arrastara-o várias vezes ao redor da cidadela de Príamo. Devemos nos lembrar, porém, que Heitor tentara atirar o corpo de Pátroclo aos cães e 
ainda lhe usurpara as vestes e armas, as quais pertenciam ao próprio Aquiles. Dessa forma, Heitor já havido transgredido o código de guerra, desrespeitando o morto inimigo, que, por sua vez, também havia sido zombeteiro e com outro troiano, a quem matara: Sarpedon ${ }^{\text {lxxvi }}$. Embora tenha se excedido na vingança do ultraje ao amigo, Aquiles demonstra respeito e compaixão ao receber o rei de Tróia, que objetivava resgatar o corpo do filho. Príamo não empreendera a jornada sem isenção de receios, ao contrário, bem sabedor da fúria do filho de Tétis, orara a Zeus para que obtivesse guarida no campo inimigo e encontrasse um Aquiles compadecido. Zeus respondera à prece, enviando Tétis para aconselhar o filho a ser gentil com o idoso adversário. Aquiles, no entanto, poderia ter matado o maior dos inimigos troianos, ou tratado o rei de maneira rude, a exemplo do que Agamenon fizera a Crises. Ambos deixaram o conforto de seus palácios para resgatar seus filhos, trazendo fortunas em bens para fazer a permuta, tudo de acordo com os estatutos de guerra. Aquiles não age como Agamenon, que ofendera o pobre pai de Criseida, mas atende com deferência o velho soberano tróico, e humildemente lhe ouve as palavras, o narrador dizendo que o fatal guerreiro toca o rei inimigo com brandura (Il, XXIV, 507-12). Príamo age segundo as leis: abraça os joelhos de Aquiles e roga-lhe a entrega do corpo de Héctor para que sejam feitos os funerais. E faz o pedido em nome do pai de Aquiles, tentando fazer o jovem compreender sua dor paterna. O guerreiro grego se emociona e o pranto toma

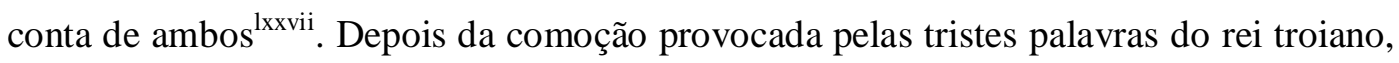
é com gentileza que Aquiles o toca, erguendo-o a uma posição condigna de sua pessoa e idade, "condoído de suas cãs", diz o narrador (Il, XXIV, 513-6) ${ }^{\text {lxxviii }}$. Note-se a atitude delicada e respeitosa de Aquiles para com o rei inimigo, pai do homem a quem matara. A magnanimidade do guerreiro grego ressurge no oferecimento de um cessar-fogo enquanto durassem os rituais fúnebres. Depois de prometer não guerrear durante os 
funerais de Héctor, Aquiles faz um gesto de juramento: “(...) E tomou-lhe a mão direita pelo / pulso, para que medo algum medre em seu ânimo” (Il, XXIV, 672-3). Assim, o que depreendemos é que, embora Aquiles tenha como característica maior a ira fatídica - sentimento polifacetário e nefasto - o guerreiro será sempre um herói admirado pelas demais virtudes, dentre elas, a gentileza para com o outro, nas relações sociais, estatuto de guerra à parte. O sábio Nestor acrescerá ao adjetivo filial de Aquiles, a palavra “imáculo" e Zeus dirá que o filho de Tétis “não é um sem tino, um sem norte, um sem lei” (Il, XXIV, 157-8).

Odisséia, de igual modo, enfatiza a bondade, retidão e gentileza de seu herói. O narrador de Odisséia liga ao nome do filho de Laertes epítetos ligados a virtudes nas relações sociais: bondoso, de alma grande, de prudentes e sábios conselhos ${ }^{l x x i x}$. Esse aspecto do caráter de Odisseu é relembrado entre os deuses do Olimpo, na defesa de Palas Atena, enfatizando que ele fora um rei bondoso, sensato e de retos desígnios:

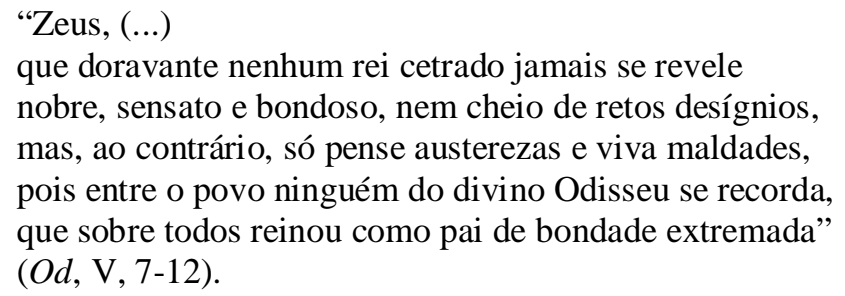

Tal norte parece ser mesmo o de Odisseu, pois ele advoga essa causa junto a Alcínoo: “(...) a nada se pode aspirar de mais alto / que ver a paz entre o povo e a alegria no rosto de todos" ( $O d$, IX, 5-6). Além da devoção aos seus familiares e compatriotas, Odisseu revela um olhar benigno aos estrangeiros e mendigos, classes execradas socialmente naqueles tempos, pelo que se vê no que diz a Polifemo. Ainda viajante perdido, Odisseu lembrara ao gigante que os mendigos são protegidos divinamente: “Aos deuses todos respeita, meu caro, pois somos pedintes; / o próprio 
Zeus é quem vinga e protege os mendigos e estranhos" (Od, IX, 270-1). Algo semelhante se dará no banquete de Alcínoo e na censura que Odisseu, disfarçado de mendigo, fará a Altínoo, o mais arrogante e mordaz dos pretendentes ${ }^{\operatorname{lxx}}$. Odisseu também é cordato e conselheiro. A Telêmaco o velho Nestor diz que Odisseu e ele eram os grandes conselheiros na guerra de Tróia ${ }^{\text {xxxi }}$. Lembremo-nos de que Nestor, na Ilíada, era considerado o melhor dos conselheiros gregos, o único capaz de censurar o rei ou dele discordar. O sábio homem, porém, o fazia com tal diplomacia e elegância que mesmo o irascível Agamenon se sentia grato pelo palpite. E se o próprio Nestor reputava Odisseu um bom conselheiro, confirmando que ambos nunca tenham divergido em opinião, é porque o narrador da Odisséia intenta aproximar o caráter de ambos, mostrando ao leitor a excelência de sabedoria de que o marido de Penélope era dotado.

Odisseu não demonstra bondade apenas para com os seres humanos, mas estende seu olhar compassivo aos animais. Um deles é mencionado com ênfase especial: o cão Argos, que, muito doente e enfraquecido, reconhece o dono assim que esse chega ao palácio. Disfarçado de mendigo, Odisseu fica atônito com o deplorável estado do animal e faz perguntas ao porqueiro, Eumeu, com o objetivo de averiguar o porquê da situação. Eumeu atribui a triste condição de Argos ao relapso dos servos encarregados da tarefa de tratar do bicho ${ }^{\text {lxxxii }}$, ressaltando assim a relevância do assunto para os gregos antigos.

Bondade e compaixão são elementos preponderantes do caráter de Enéias, que se revela um pai atento, dedicado ao filho Ascânio: magnânimo e cuidadoso com os seus companheiros de luta, e também apaziguador nas pendengas que ocorriam entre os troianos $^{\text {lxxiii }}$. No final da narrativa, ao vacilar ante as súplicas de Turno, Enéias demonstra ser acometido por uma súbita compaixão que por pouco o fará desistir de 
matar o rival: "Pondo-lhe os olhos, reprimiu a destra / Enéias; mais e mais de Turno as vozes / Lhe iam dobrando o ânimo (...)” (En, XII, 1272-4).

Quanto a Bernardo, a famosa ira que o acomete tem em seu epicentro um sentimento paradoxal, algo inefável que o narrador conceituará, assumindo a voz de Teresa, como brandura. Quando Bernardo recebe a carta de Nestor cobrando os aluguéis, ou instigando o barraqueiro a apresentar recibos dos pagamentos desses aluguéis - algo que não havia sido nem ao menos cogitado por Miguel - o esposo busca o apoio da mulher, ao informar-lhe resumidamente o conteúdo da missiva. Veja-se como o narrador insere as conjecturas de Teresa: "Fitavam-na os olhos azuis cheios de uma ira tensa e extática (...). Porém que brandura luzia, serenamente, no cerne daquela ira?" (OFP, 144). Essa brandura (direcionada à mulher) mesclada à ira (por conta da insólita exigência de Nestor) já se manifestara antes, em gestos ternos para com a esposa, após um evento qualquer e desagradável tendo Nestor como mandante, ambos, marido e mulher, desalentados sob a tensão que os acontecimentos provocavam: “Teresa estava ali. (...) Ele veio, pôs a mão no seu ombro, impeliu-a com brandura para dentro. (...) Ela estava sentada, agora de costas (...). Com súbita aspereza, Bernardo fê-la voltar-se, encarou-a (...)" (OFP, 112). De fato, certa gentileza de Bernardo é vista em pequenos - ou grandes - atos dispensados não apenas a Teresa, mas também aos demais parentes e empregados. À mãe, enquanto essa vivera, Bernardo devotara um sentimento respeitoso e afável: "Queria a Lucinda, cada vez mais, um bem profundo e largo (...)" (OFP, 9). Ao sobrinho, dedicava tempo e atenção, como já vimos, reparando e criando brinquedos, soltando pipas, indo ao cinema com o garoto, além das "partidas de bilhar" $(\mathrm{OFP}, 16)$. Note-se o carinho com que se reporta ao menino por ocasião da mudança de Vitória para o Surrão. Ao perceber a tristeza de Ascânio, o tio demonstrara real afeto na despedida, tocando, abraçando o jovem órfão que vivia carente de manifestações 
sentimentais assim tão generosas, já que a avó era por natureza não afeita a gestos delicados e alegria: "Bernardo veio, levantou-o acima da cabeça. Perguntou se também queria ir, levou-o nos braços até o caminhão; largou-o na calçada, meteu-se na boléia com Teresa" (OFP, 39). Com a sogra Bernardo é paciente, relevando as amargas críticas a "alusões mansamente ferinas" (OFP, 98), como ele mesmo diz, e até louvando a franqueza da mulher, encarando essa qualidade dúbia pelo seu lado positivo: coragem de falar abertamente o que entrevia na alma dos outros: "Somente sua mãe diz com franqueza o que pensa" (OFP, 4).

O olhar compassivo de Bernardo aos desafortunados ou subalternos aparece no relacionamento profissional que mantém com Antônio, relação essa caracterizada mais pela amizade e companheirismo do que pela hierarquia. Bernardo manifesta respeito e afeto a Antônio, inclusive elogiando o funcionário perante outrem. Com a intenção de obter um emprego para o ex-funcionário, Bernardo elogia Chá para Miguel Benício, usando uma metáfora ligada às conversas que mantinha com Marinheiro, em que tanto falavam de ouro: "Ouro de lei" (OFP, 28-9) é como ele conceitua o jovem trabalhador. E diz: “(...) Antônio Chá não é de artimanhas (...)” (idem). Uma vez no Surrão, tendo o ex-empregado como seu atual subalterno, Bernardo preocupa-se com sua solidão e para atenuá-la, promove, deliberadamente, um ambiente amigável. O narrador diz: “Algumas noites, com pena de Antônio que chamava o sono sozinho no seu quarto, Bernardo ia até lá, trocava algumas palavras com ele, falava nos trabalhos que os esperavam para o outro dia, batia no seu ombro, deixava-o" (OFP, 66). A bondade, atenção e respeito de Bernardo para com Antônio Chá transparecem nas palavras do empregado. Chá assim mostra o que o patrão representa para ele:

"Em sua vida pobre e errante, alugando os braços a desconhecidos que o ignoravam, consolava-se em pensar, nos momentos de obscuridade 
mais pungente, que a umas léguas havia um homem mais alto do que todos, que lhe estendera a mão como um igual" (OFP, 25).

Antônio Chá observa que Bernardo, dentre tantas boas qualidades de caráter, demonstra sincero interesse pelas pessoas: “(...) E se interessava pelos outros (...)" (OFP, 22). No relacionamento amigo com Miguel, a gentileza e o cuidado de Bernardo reaparecem na preocupação com o sofrimento do outro. Ele questiona acerca dos reais motivos para a depressão física e mental do amigo: "Qual seu padecer, desejaria Bernardo perguntar, qual a sua insônia, a sua dor mais forte?" (OFP, 27). Sem as respostas a tais perguntas, Bernardo, sempre tão discreto e nunca invasivo, propõe mudanças, visando o bem-estar do patrão, sugerindo que mude o escritório para o andar de baixo, em ambiente não tão isolado, por exemplo, e aconselha Miguel a realizar, animar-se em algum projeto e não pensar em morte. $\mathrm{O}$ reservado Bernardo até mesmo ousa aconselhar Miguel, nos momentos mais críticos, como o da idéia de matar o suposto rival. Bernardo lembra que o assassinato dessa pessoa poderia prejudicar o amigo, colocando-o em situação pior do que a atual ${ }^{\text {lxxxiv }}$. Miguel agradecerá aos sábios palpites: “- Você está aconselhando bem, compadre. Eu é que estou fora dos eixos. Pode ir embora" (OFP, 90). Enfim, Bernardo sabia ordenar bem os negócios aos quais se dedicara na vida, ao mesmo tempo em que assumia uma atitude gentil para com os que o rodeavam. Essa dicotomia é, pelo narrador, metonimizada nas mãos e pelos olhos. No primeiro caso, as mesmas mãos que a Antônio Chá "pareciam carregadas de mando e segurança" (OFP, 24) eram as mesmas que, em reunião familiar fechara "docilmente" (OFP, 13) a porta ao sair e as que fazem o carinho tímido na mulher que, deixando de lado o impulso amoroso feminino, ainda guardava o luto pelo filhinho morto: "Bernardo tomou a sua mão, colocou-a sobre o próprio ombro. A mão do marido era grossa, afeita a duros trabalhos, mas se fechava com timidez e doçura sobre a sua - e Teresa se 
entregava àquele gesto com uma segurança calma (...)" (OFP, 45). No segundo, os olhos de Bernardo, vistos sob a ótica de Antônio Chá é que se revestem de ricos sentidos, carregando metonimicamente as qualidades que o empregado vislumbra no patrão e amigo. Os olhos são azuis e "sossegados" [numa referência às águas calmas que inspiram serenidade], mas, paradoxalmente, "pesados e duros, zargunchais, coronhadas numa pedra" [mais uma referência às guerras, pois zargunchos são dardos e o termo “coronhadas" nem carece de explicação]. Antônio conclui que são olhos "fortes" (OFP, 25).

A cortesia de Bernardo, porém, não se faz notar com segundas intencionalidades - alcançar fins egoísticos, como obter favores alheios. Gumercindo Rocha acha que Bernardo intimamente o censura por isso e admoesta: “- Você com a sua intolerância! Quem sabe! É preciso ser cordato, tratar bem as pessoas" (OFP, 155).

Bernardo também demonstra apreço pelos animais. O narrador diz de seu empenho em possuir bichos de todo o tipo: "Vieram galinhas (...). Comprou uns passarinhos cantadores - um galo-de-campina, uma chorona (...)" (OFP, 65). Se o leitor é levado a achar que a criação de animais tinha um fim estritamente pragmático vender ou usar os bichos na alimentação, vale observar a maneira como Bernardo trata sua criação. Princesa, a vaca; o bezerro e demais bichos da fazenda recebem seu olhar cuidadoso: "Afagou o lobo de Princesa, sopesou-lhe o ubre, olhou para o bezerro que saltava (...)" (OFP, 104); mas o maior exemplo de apego aos animais está no companheirismo com o burro que ganhara de Miguel. O animal é quase uma extensão de Bernardo, estando com ele nos momentos mais críticos, do início ao fim de sua estada no Surrão. O narrador insere o olhar de Bernardo dirigido ao animal, em quase todos os momentos-chave de sua trajetória. A título de exemplificação, citaremos alguns: Após a recusa da proposta de Miguel, de passar em cartório certos bens imóveis, 
a ação do bicho não é descartada: "Descera a escada grosseira (...). O burro girara - os cascos, duramente, haviam batido nas pedras" (OFP, 72); o mesmo se dá quando Nestor, que concordara a falseta, se apressa em tomar posse dos bens do irmão, levando Bernardo a pressentir a morte do patrão:

"Por trás dele, Bernardo reprimia o desejo de curvar-se, agarrá-lo pelo braço e gritar que não matasse o irmão. Voltou-se, olhou a cena tantas vezes vista daquele mesmo lugar: o velho calçamento além das portas, os empregados em mangas de camisa, seu burro espantando as moscas" (OFP, 75-6)

Bernardo refletia sobre sua continuidade no Surrão, o animal é descrito no ato de alimentar-se: "O burro comia, os flancos lustrosos, à sombra da manjedoura” (OFP, 104); na viagem a Vitória, com o objetivo de conversar com Nestor, o compasso ritmado do andar do burro é notado: "Avançava o sol, a andadura do burro era uniforme e suave. (...) Seguindo sozinho, embalado pelo ritmo seguro da montaria e cercado pela calma das paisagens (...)" (OFP, 144-5); depois dos tiros, a atuação do cavaleiro no lombo do animal: "Bernardo estremeceu e manteve-se na sela, as pontas das botinas firmes nos estribos" (OFP, 228); e, por fim, no confronto final, a quase-morte ainda em cima de seu burro: "E os tiros e a perda de equilíbrio, a inclinação na sela, a rejeição do fim e o esforço para se agüentar montado (...)" (OFP, 309). Um momento apenas, após a morte de Miguel, e mediante a reflexão da vida e seus altos e baixos, a ira é mais forte do que o carinho pelo animal que o acompanha nas mais difíceis horas: "Sem precisão, esporeou o burro" (OFP, 98).

A impressão que se tem é que o autor inspirou-se de forma relevante nos heróis greco-romanos que podiam ser rudes e agressivos em alguns momentos e bondosos e justos, passíveis de atitudes gentis e delicadas (como o impagável Aquiles...) em outros momentos, para compor esse quesito de seu protagonista. 
Todavia, diferentemente de Aquiles, tão comunicativo e próximo à mãe $e^{\text {lxxxv }}$, buscando Tétis para ajudá-lo a digerir suas mágoas, Bernardo é extremamente reservado na infância e juventude, nunca fazendo confidências a alguém, nem mesmo à mãe, não se expandindo na comunicação com o outro. Ainda nesse quesito da capacidade de boa comunicação, o narrador qualifica-o como "homem de contadas palavras" (OFP, 8), mas deixa claro que Bernardo gostava da mãe; no entanto, não se furta a esclarecer sem arroubos: "Queria a Lucinda, cada vez mais, um bem profundo e largo, sem nenhuma expansão" (OFP, 9). Nos encontros de família, em que a prima Teresa sempre se fazia presente Bernardo se mantinha isolado, aparentando indiferença: "vinha, sentava-se na sala e punha-se a olhar para fora, através da janela" (OFP, 11-2) e, mesmo ouvindo a mãe perguntar a Teresa sobre os estudos, ele permanecia à parte de tudo, condição que o narrador explicita: "parecia ausente, como um homem que remói uma vingança". Lucinda recriminava o mutismo do filho, lembrando que ele não era ainda tão amadurecido quanto o demonstrava sua sisudez: "Por que você não fala, Bernardinho? Ria. Você não tem idade para ser tão ciente" (OFP, 11-2). E que sentimentos pululavam no jovem Bernardo para lhe provocar tal alienação? Seria, talvez, o anseio de se meter pelo sertão afora? Para contemporizar e defender o primo, Teresa justificava: Bernardo estaria pensando em viagens. O rapaz negava com a cabeça, fitando-a. Porventura já se mostraria aí a semente de uma paixão juvenil? Na verdade, o narrador diz que nem a própria personagem atinava com o sentimento que ia tomando forma com a convivência: "Ninguém sabia e os sentimentos que haveriam de determinar os rumos de suas vidas, formavam-se com energia em suas almas. Quem poderia adivinhar que nos silêncios, como nas palavras sem definida intenção, geravamse anos inteiros, com mil segredos no seu bojo?” (OFP, 12). E tal alheamento em relação a coisas do coração se manifesta em outra reunião de família, a ceia a que 
Bernardo fora convidado, na casa de Suzana. Nessa ocasião, Álvaro confessara seu amor por Cissone, irmã adotiva de Bernardo. Muito constrangido, Bernardo diz a Teresa que nele tudo demorava a crescer, enfim, seu tempo era um tempo lento e comedido $^{\text {lxxxvi }}$. E embora o narrador diga que, naquele momento, uma "chama desesperada" acendera-se em Bernardo, uma chama que Teresa nunca havia percebido no primo; ficamos sem saber se essa chama é o amor ou - irritação. Afinal, não alcançava como o primo, plena certeza desse amor para, enfim, expressá-lo à mulher que o teria inspirado. Um homem angustiado, ao que parece... Um homem que, permanecerá com essas mesmas inquietações por mais cinco anos até decidir-se, enfim, por Teresa: "Quanto esperara a confissão! Cinco anos. Morrera Cissone, Álvaro morrera, e o amor de sua adolescência estava vivo esperando em silêncio aquele instante". Com o decorrer da narrativa, vamos percebendo um Bernardo consciente de sua constante intranqüilidade de espírito, o que atesta a pergunta a si mesmo formulada, como num clangor de alma: "Serei sempre assim, pensou, um homem sem sossego (...)?” (OFP, 48).

\section{Refúgio na natureza}

A natureza não é indiferente aos heróis, mesmo que essa noção seja apanhada em doses mínimas. A intensa ira de Aquiles encontra amenização - pelo menos em sua força autodestrutiva, embora a resistência persista - na natureza. Com a perda da honra, representada pela apreensão da cativa que se tornara sua esposa, Aquiles busca a paisagem marítima para atenuar sua emoção ${ }^{1 x x x v i i}$. Odisseu também encontrará junto à natureza o refúgio para sua tristeza e saudades. Calipso, após a visita de Hermes, vai encontrar o herói, como Aquiles, chorando junto ao mar. Está certo que Odisseu contemplava o vasto oceano com os pensamentos longe, em sua ilha e nos que lá 
viviam $^{\text {lxxxviii }}$. Talvez por tantas belezas e tanto conforto, além dos mimos da ninfa apaixonada, o narrador mencione a "doce vida" de Odisseu. Enéias, ansioso pelos acontecimentos a se formarem, procura repouso junto à natureza, especificamente, à beira de um rio. Contudo, é nessa natureza, como sempre, um tanto adversa, o que transparece na expressão ao frio relento, que ele encontra além da tranqüilidade para um descanso, o incentivo na prossecução de seus objetivos ${ }^{\text {lxxix }}$. É da natureza que Vênus retira o poderoso bálsamo que iria restaurar a vida a seu filho ferido na batalha (a Eneida conta que a erva colhida por Vênus no monte Ida já era conhecida pelas cabras feridas pelos caçadores $)^{\mathrm{xc}}$.

Em $O$ fiel $e$ a pedra, a natureza acompanha os conflitos interiores do protagonista e um exemplo ocorre no caso em que Bernardo vive horas de agonia, ruminando a proposta de Miguel:

"O coaxar dos sapos se cruzava, alarido úmido; a largos espaços por sobre a cantoria deles, o uivo de um cachorro atravessava as trevas. Vinha de tão longe! Os grilos estalavam, numerosos, ratos deslizavam sob as telhas. Havia um novo rumor: o chocalho de Princesa, a vaca prenha, ruminando só no cercadinho" (OFP, 72).

É impossível não atentar para a riqueza dessas imagens, as trocas semânticas como na sinestésica expressão "alarido úmido" ou "o uivo do cão atravessava as trevas" [grifos nossos]. Não só aqui, nesse ponto específico do livro, mas em tantos outros, Osman Lins parece ter a intenção de pintar um quadro, um cenário para nele inserir seu protagonista. E esse cenário, quase sempre, é ambientado com os sons naturais. A natureza emoldura a dor, a angústia e as poucas alegrias das personagens do romance, mas o narrador não pinta as plantas, as flores, os sons naturais, para o deleite do leitor, tão somente. O narrador estará sempre remetendo as personagens para as cenas naturais, fazendo-as ouvir, de fato, a sua voz e sentir seus odores. Poderíamos dizer que há uma 
interação completa entre homem e natureza, pois essa última acompanha o estado de ânimo da alma dos personagens - e aqui estendemos a ação da natureza não apenas ao protagonista. No episódio da reflexão pós-proposta, os ruídos da noite se fazem como fundo musical para a angústia de alma que move o coração do protagonista. Miguel, o homem que sempre lhe comprava burros, havia solicitado o favor de permitir que esse transferisse os bens para ele, a fim de que pudesse se desfazer das propriedades sem partilhar com a esposa infiel. Mas Bernardo, sempre obediente a um conceito rigoroso de moralidade, discordara do conluio. Essa atitude ética, no entanto, não impede a torrente de reflexões sobre o que deveria ou não ter feito:

"Bernardo, os olhos fechados, não alterava o discreto balanço da rede: os ganchos rangiam, num ritmo impassível, único som disciplinado na murmuração noturna. Depois de trinta e tantos anos - pensava - encontrava um amigo e não podia ajudá-lo na hora necessária" (OFP, 72).

Notamos, assim, que essas ponderações se fazem embaladas pelos sons da noite, mas não apenas percebidos como uma festiva sinfonia noturna e sim como vozes da natureza, que alçavam seu canto e se misturavam aos pensamentos de Bernardo, esse, por sua vez, balançando-se na rede em que se deitara. Há harmonia entre o ritmo cadenciado e monótono da rede do homem reflexivo e a intensa e variada mistura de ritmos da noite campestre. Os ritmos, então, se entrecruzam, mostrando, de maneira metafórica, as tantas vozes que se entrelaçam nos pensamentos de Bernardo. Será assim na maior parte do romance, nesse aspecto da inter-relação homem-natureza. A natureza indicará às personagens que há vida no universo e que é bom usufruir dessa vida, é bom viver, apesar dos problemas. Depois da morte de Miguel, Bernardo se põe a pensar no triste acontecimento, enquanto, do armazém, observa os flocos de paina caindo. A cena entrevista através dos olhos do barraqueiro funciona como metáfora da vida que se esvai: "Os flocos das paineiras haviam começado a cair. Sentado por trás do balcão, 
inativo, Bernardo contemplava-os. Miguel estava morto, isto era um fato concreto. E o irmão senhor dos seus domínios, a maldade exasperada pelas riquezas que roubara" (OFP, 205). Para o leitor resta o dado premonitório: os flocos de paina caem, certamente, mas ao caírem, fazem renovar a vida, pois dentro de si carregam a semente que redundará em nova planta. A morte de Miguel, de certo modo, frutificaria, promovendo novos rumos à vida de Bernardo e sua família, até ao ponto da plena restauração.

Outros exemplos da natureza compondo o momento dramático surgem em toda a narrativa. Prestes a se enfrentar com Nestor, Bernardo "olhara com um travo na alma o começo da estrada, com a sua fila de eucaliptos" (OFP, 213). Mas, o exemplo maior dessa interação homem-natureza acontece no enfrentamento final, quando Bernardo sente que irá morrer, de qualquer jeito. Primeiramente, há uma descrição de intenso cunho grandiloqüente sobre os sentimentos que acossam o protagonista por ocasião da luta psicológica com Nestor:

"Mal via onde pisava, estava quase cego, tudo era confuso e vacilante. Um dragão rodeando-o, um monstro rastejante, envolvendo-o em suas asas de silêncio. E no círculo invencível e sempre mais estreito sangue num membro estrangulado - a solidão engrossando. Nas trevas deparou o olhar da morte, do animal, o olhar de Ubaldo, um olhar que pareceu atravessá-lo - dardo - e cravar-se na ponta da parede" (OFP, 308).

Percebemos aqui os sentimentos terrificantes expressos como símbolos, outra recorrência à mítica grega, que viaja, em atualizações, através dos séculos à medieva idade - o dragão monstruoso - inclusive na imagem que muito se vê em Ilíada, a de um dardo que, atirado, erra o alvo e se crava em um ponto qualquer. É o desenho da Morte. Mas, observe-se o que temos a seguir, na mesma página, em continuidade dos pensamentos e sentimentos da personagem que caminha para seu momento final: "Bernardo pôs o pé no estribo. (...) sentiu que anoitecia (...). Os morcegos saíam. 
Sobrevoavam a casa, o bananal, o engenho, os homens empedrados" (OFP, 308). Mais uma preciosa imagem se faz notar com a dicotomia entre os morcegos - animais noturnos, símbolos, por si só de acontecimentos desagradáveis - e os homens. Os pequenos animais se apresentam dinâmicos, cheios de energia, leveza e vida, voando por sobre os seres humanos - esses, destituídos de dinamismo, leveza de ações e, mesmo, humanidade, pois que estão "empedrados". Na seqüência, Bernardo remete os pensamentos à natureza, novamente: “(...) sentiu que anoitecia e recordou a manhã cheia de sol, o carneiro balindo, o resinoso odor dos cajueiros florando" (OFP, 308) . A noite trazia a morte, enquanto a manhã - a vida, exatamente como no abrir da narrativa - a agonia da noite simbolizando a morte do filho, gradativamente, deixava lugar para a nova manhã. Mais uma vez, essa inserção da natureza é uma espécie de dito premonitório do autor: diante da iminência do trágico fim do protagonista, nos conforta a lembrança da "manhã", ou seja, da vida. Mais uma vez e por outros códigos, sabemos que Bernardo não morrerá. Ao contrário, sairá vitorioso do embate terrível.

\section{Herói que vacila}

Angústia, aflição, indecisão e, paradoxalmente, temor, se misturam à ira de alguns dos heróis greco-romanos. Mesmo o intrépido Aquiles manifesta vacilação de sentimentos. É famoso o excerto em que o grego revela sua hesitação:

“(...) No peito hirsuto do Peleide a angústia assoma. O coração, partido em dois, hesita Ou arranca do flanco a espada pontiaguda e afastando os demais abate o Atreide no ato, ou reprime o furor, doma a revolta no ânimo. Tudo isso lhe rodava no íntimo e, entretanto, ia sacando da bainha o gládio enorme" (Il, I, 188-94). 
Aquiles envolve sua ira com um tom melancólico, triste, depressivo, em que a autopiedade e revolta impotente se fazem sentir. Os lamentos se expressam de forma negativista, como se vê: "Nada me adveio, após jogar a vida e tanto / padecer, a lutar, expondo-me sem pausa" (Il, IX, 321-2). Até mesmo o medo comparece entre os sentimentos desse invencível guerreiro. Diante do rio Escamandro, ele demonstra intensa aflição: "Toda vez que o Peleide estaca e encara o rio, / (...) o vagalhão açoitalhe / a espádua, espadanando-a do alto, e ele se lança / para cima, apoiando-se nos pés, aflito / o coração (...)” (Il, XXI, 268-9). Nem mesmo o otimista Odisseu escapa dos sentimentos dúbios, da insegurança e ansiedade. Veja-se pela oração que faz:

"Zeus pai, se foi por vontade que alfim me trouxeste por terra e pelas úmidas vias, depois de sofrer tantos males, dá que aqui dentro de casa alguém diga, acordado, palavras de fausto agouro, e que fora me venha um sinal de tua parte" (Od, XX, 98-9).

Enéias, então, é dos mais vacilantes heróis de nossa lista, mostrando-se receoso, desanimado e mesmo desesperado, em certos momentos. Não nos deteremos a descrever cada caso, mas um deles é perante a tempestade que acomete as embarcações dos troianos. Enéias clama aos céus que melhor seria ele e os seus companheiros terem ficado em Tróia, morrendo por lá do que enfrentando tal fúria da natureza:

"N'isto Enéias, d'um frio horror tomado, Geme, e ambas as mãos aos céus erguendo, Oh mil vezes, exclama, venturosos Os que de Tróia junto aos altos muros À vista de seus pais morrer puderam" (En, I, 138-42).

Outro evento em que os temores se instauram é o sonho com Heitor, avisando da devastação de Tróia. A reação de Enéias é atarantada ${ }^{\text {xci }}$. Mais uma situação em que 
Enéias se expressa com desalento, surge durante a narração das desventuras dos troianos, quando dirá: "Ai! Quanto o céu não quer tudo é baldado!” (En, II, 620). Vacilará o herói tróico, mais uma vez, após receber a censura de Mercúrio, oscilando entre contar a verdade a Dido, sobre a necessidade de partir, ou inventar uma desculpa qualquer: "Quer fugir e deixar as doces praias. / Ai! Que fará? (...) Veloz divide / ora aqui ora ali a fantasia" (En, IV, 411-5). Paradoxalmente, o filho da deusa dormirá após encerrar o caso com Dido, numa atitude de aparente alienação, fato que irá gerar outra repreensão de Mercúrio: "Filho da deusa, / Dormes n’uma tal crise? Não vês (louco!)/ Que iminentes perigos te rodeiam?" (En, IV, 848-9). Novamente o herói virgiliano será tomado por ansiedade, temor e preocupação, mesmo depois das palavras incentivadoras do velho áugure, Nautes: "Do velho amigo os ditos animaram / O coração do herói; mas logo a mente / Tornou a dividir por mil cuidados" (En, V, 1030-2). E após ter atendida sua oração a Zeus, no episódio dos navios em chama, ainda estará "turbado" e temeroso: "Com tão acerbo caso o herói turbado / Agora este cuidado, agora aquele / Volve no grande peito, irresoluto, / Pensando, se dos fados esquecido, / Nas terras da Sicília ficaria" (En, V, 1005-9). Finalmente, o herói de Eneida voltará a titubear já no final, ante os rogos de Turno: "Pondo-lhe os olhos, reprimiu a destra / Enéias; mais e mais de Turno as vozes / Lhe iam dobrando o ânimo (...)" (En, XII, 1272-4).

Bernardo vacila ante as forças que fermentam dentro dele: desânimo: ao ser questionado por Antônio Chá quanto à probabilidade de encetar novas viagens, diz: “A vida amarra o homem, Antônio. Vai-se perdendo o faro. Até o jeito de andar a gente perde" (OFP, 24). Rememorando sua vida pregressa, considera-se cansado dos tropeços que a vida lhe reservara: "Muitas águas correram sobre mim, estou ficando velho, caio sempre, recomeço" (OFP, 98): A insegurança, o medo, a desconfiança quanto ao futuro se mostram, pouco a pouco, nos vários momentos de incerteza. A condição de 
fragilidade da esposa - a gravidez -, mais ainda o aflige, pois cobra de si mesmo a proteção que considera não estar oferecendo à família. Bernardo, considerando-se um insensato por priorizar a fidelidade ao norte da consciência, lamentando-se no íntimo, entretanto, por não lograr oferecer-lhe vida melhor e, conseqüentemente, proteção. Moça ainda, a namorada lhe teria dito: "- Você tem músculos duros como nervos" (OFP, 189) e agora o marido, se lembrando do comentário, pensa: "Duros, mas não sábios. Era bastante forte para levá-la nos braços - e no entanto, se acontecesse morrer naquele instante, que lhe deixaria?". Essa constatação da força física como insuficiente para suportar o peso das adversidades parece aludir-se à grande força muscular de Aquiles, chamado "o mais forte dos Aqueus" (Il, XVI, v. 21), mas impotente diante do destino que lhe é reservado - a breve morte. Aquiles dirá a Licáone que, embora seja forte e dotado de esplendor físico, um dia morrerá - portanto, a beleza ou a força não significam muito ${ }^{\text {xcii }}$.

Na Odisséia, Menelau fica estarrecido com o que lhe informa Telêmaco sobre os pretendentes e comenta: "Pois é possível que tais indivíduos, sem força nenhuma,/ queiram deitar-se no leito de um homem como este, tão forte!" (Od, XVII, v. 124-5). Mas assim se davam os fatos. Odisseu, mesmo forte, teve sua casa invadida e não pôde proteger a esposa. Enéias, com seus fortes músculos, carregará o pai às costas, mas, no mesmo evento, perderá a esposa. Mais adiante, o herói será chamado, uma vez, de forte - ${ }^{\text {xciii }}$ quando se preparar para o enfrentamento com Turno - outro jovem forte [e o rei Latino observará que esse e Enéias serão dois homens fortes: "Latino pasma ao ver dois varões fortes, / (...) / Conceder em pugnar té que um ai outro / Deixe livre co'a morte, o cetro, a esposa" (En, XII, v. 970-3)], mas essa força física quase será quebrada pela complacência ou fraqueza de impulso bélico. 
Bernardo, em outra circunstância, arrepende-se das atitudes do passado e conclui ser um homem "de energias mal domadas" (OFP, 249). Em outros momentos, insiste em permanecer no silêncio de seus dilemas, pois considerava a mulher o ser mais frágil, dentre os dois, ao mesmo tempo desejando repartir com ela todas as angústias, sentindo que "sua força tombava, e que era inevitável ceder, entregar-se à proteção da esposa. Quem de nós é mais frágil, quem tem peito mais largo, quem deve amparar?” (OFP, 250) e se dobrará à veleidade que o atormenta: "Se desatasse aquele segredo, a ira, a incerteza, o medo, confessasse tudo?" (OFP, 231). Depois de decidir-se a partilhar a angústia com Teresa, ainda não se sente aliviado da opressão psicológica que a si mesmo impõe. Como previra, o pranto é a marca externa da dor da alma companheira e a sensação de culpa aumenta em intensidade. Os abraços de Teresa amenizam somente em parte o seu sofrer. Ao perceber o grupo de homens estranhos [em todos os sentidos] no barracão, em horário noturno avançado, percebe de forma sutil e quase imperceptível, o medo ser transferido de Teresa para ele:

"Bernardo percebeu-o [o medo de Teresa], ao mesmo tempo que sentia no coração o desabrochar daquela flor parasitária, que parecia alimentar-se de sua coragem (pois a consumia) e era como um reflexo ou uma transplantação da que empalidecia a mulher e lhe arroxeava os beiços" (OFP, 185-6).

Nesse mesmo episódio, após a saída do grupo, Bernardo concluirá que o terror estivera visceralmente entranhado a ele: "Começava a suspeitar de que o medo, embora assumindo formas várias, não o deixara um momento e zombou de si mesmo". Ao final, quando decidir por afastar a esposa do Surrão, prevendo as desagradáveis circunstâncias do acerto de contas, o herói admitirá seu pavor ante a solidão:

"Aquele impulso angustiante de ir ao seu quarto e acusá-la, obrigá-la a ficar, mesmo estando certo que isto haveria de vencê-lo! Quantas vezes, 
com os punhos tão cerrados que doíam, rumara para o corredor, sabendo que não eram as suas forças, mas a sua parte mais indigna que o obrigava a isto!" (OFP, 267).

Depois que volta de Vitória, onde tinha deixado a esposa para, sozinho no Surrão aguardar o acerto com Nestor, o desânimo, a angústia e o amargor em relação à vida é o que se percebe na descrição a seguir: "Tresnoitado, cansado, mas sem sono. E triste. Toda a viagem de volta fora um remoer lembranças - e cada lembrança deixava um novo pesar, acrescentava um travo à amargura mais ampla. E não vinham porque as chamasse: vinham. Esse involuntário recordar matava-o, abria-lhe as veias, fazia-o sangrar. Uma vida inteira sem triunfos" (OFP, 267). Na decisão tomada, de permanecer só e enviar a esposa à casa da sogra evidencia-se a patente realidade - perdera o chão: "Casa sem apoio, casa sem Teresa" (OFP, 270). Nessas reflexões angustiosas que se seguirão, Bernardo compreenderá que os tiros na estrada, não poderiam ter a pretensão de matá-lo, mas de lhe infundir temor. Depois do incidente, Nestor o visitara no Surrão e insistira, novamente, em que ele capitulasse ante sua vontade - permanecesse na fazenda, aceitando-o como novo mandatário. Lembrando-se desse novo assédio, Bernardo sente-se orgulhoso por manter a recusa em cooperar com Nestor. E conclui coexistirem em si mesmo dois Bernardos: um temeroso - porque não atentara para com a verdade das intenções de Nestor; outro valente - por haver sido fiel aos seus próprios ditames de consciência: “(...) sentira-se grato àquele outro Bernardo, tão vulnerável às intenções do inimigo - uma vez que as desconhecia - e que reagira como se nada ignorasse" (OFP, 284). Ao final de sua história, durante o nervoso acerto de contas com Nestor, titubeará entre matar Nestor, ou não, e mentalmente, pedirá socorro à esposa, vacilando entre a ação e a inação: “Ah, Teresa, salva-me do mal, de todo o mal!” (OFP, 299). 
Enfim, irado e valente; inteligente, mas prudente; construtor dedicado à família; cidadão, marido e pai franco, bondoso, sensível ao mundo natural e, no entanto, um herói também receoso, inseguro - um tanto feminino: esse é o retrato do herói de Osman Lins: "o valente, sem pabulagem". Talvez a expressão que mais exemplifique essas qualidades de Bernardo sejam as considerações que Antônio Chá faz a si mesmo: "Famoso homem, nunca visto igual, de suma lealdade e retas decisões. Modelo de grandezas. E se interessava pelos outros (...)" (OFP, 22). E as palavras de Ubaldo, ao final da história: "Um macho desse carece viver" (OFP, 309). A estrofe da canção tomada de empréstimo no início do livro fecha-se com um dado importante: o herói, embora dotado de qualidades que o aproximam dos semideuses gregos ou troianos, veste as cores das plagas verde-amarelas, uma clara transposição do épico tradicional para a realidade brasileira (e, assumindo um cunho visivelmente autobiográfico, da mesma cidade do autor do romance). Com tal apropriação epopéica matizada dos tons nacionais, o autor nos diz da influência que recebera dos poemas épicos antigos, herança essa que ele transforma em ingrediente para a sua criação, a qual, advinda do homem brasileiro que é, só pode apresentar nossos traços. Em O fiel e a pedra observamos, pelo exposto, um discurso que se faz imiscuído tanto do narrador das epopéias mencionadas, quanto da fala e ações dos heróis, o que foi constatado por Bakthin no romance dostoievskiniano ${ }^{\text {xciv }}$. As vozes desses heróis se coadunam, na maior parte dos casos, compondo o “valente, sem pabulagem” da canção - o herói 'anônimo', uma vez que dele não conhecemos a identidade e cujas características se fundem às de Bernardo. Assim, já não temos um Aquiles ressentido ou colérico, um Odisseu engenhoso, um Enéias dedicado à missão, um lusitano ousado nas viagens, mas um herói que é a junção de todos eles. Não seria uma paródia, porque o caráter de Bernardo não entra em choque com as características-modelo desses heróis. Também não estamos 
diante de uma paráfrase simples, pois há certo deslocamento das virtudes que cristalizam tal ou tal herói. Seguindo as opiniões de Bakthin, a estilização é a categoria que mais se aproxima da criação osmaniana nesse romance, pois Osman Lins não oblitera a presença de Aquiles, Odisseu, Enéias, antes os deixa entrever no perfil de seu herói, fato que ratifica as palavras do russo: "O estilizador usa o discurso de um outro como discurso de um outro e lança uma leve sombra objetificada sobre esse discurso"xcv . Até aqui vimos como se mostra o perfil heróico do protagonista em $O$ fiel $e$ a pedra. E como tal herói é mostrado após cerca de vinte e cinco anos? Modificado? Não. O narrador insere esse herói amadurecido, próspero, ainda fiel à esposa, ainda forte e audaz e mais sábio:

"Ao seu lado [de Teresa], com muito ainda da antiga força, pequena fortuna e um grave clarão interior (a vida lhe parece, em certas horas, um velho bicho selvagem, adormecido a seus pés, Bernardo Cedro começa a envelhecer. Teve no curso desses anos, atribulações; não porém, superiores ao quinhão habitual que um homem recebe da vida" (OFP, 313-4).

Outro dado a respeito de Bernardo é de que, nos quase cinco lustros, sofrera outras provas - e o narrador releva tal fato, lembrando que as "atribulações" (OFP, 314) se equiparariam às que acometem a todos os seres humanos. Veja-se que o narrador informa que Bernardo percebe a vida tal qual uma fera domesticada - uma alusão implícita ao animal aos pés de Santo Antão, na pintura sacra que tanto impressionava o menino Ascânio. 


\section{PARTE II - VOZES}

Os heróis homéricos e o virgiliano nunca agem sozinhos, isolados de seu mundo; ao contrário, escutam outras vozes que objetivam domar sua ira, instigar ações, ou ainda corrigir as sendas escolhidas para sua jornada - caminhos esses que, sempre se imiscuem aos da comunidade como um todo (a ação nunca se faz isolada em seus efeitos). Embora Aquiles seja um herói de caráter definido - a ira projetando-se como qualidade suprema -, percebemos outros personagens da Ilíada interagindo com ele no sentido de modificar seu comportamento, ou sua maneira de ver os fatos e receber as ações alheias. Por causa da ira, Aquiles tem o ímpeto de matar Agamenon, mas é impedido, no último instante, por Palas Atena, no incidente em que o rei lhe anuncia que lhe tomará Briseida. A deusa, já vimos, segura o impulsivo herói pelos cabelos ${ }^{\mathrm{xcvi}}$. Reconhecendo Atena, o herói lhe pergunta o porquê da intervenção, ao que Palas responde estar ali a mando de Hera, para que ele deixasse em paz sua potente espada. A ira de Aquiles também é objeto do conselho de Peleu, seu pai, admoestação relembrada por Odisseu, por ocasião da embaixada enviada por Agamenon, a fim de relevar os problemas de relacionamento e convencer Aquiles a voltar para a guerra:

\footnotetext{
“(...) Meu filho (...)

(...). Refreia o ânimo ardoroso: melhor é sempre a bem-volência;

a ira - procuradora de males - afasta"

(Il, IX , 254-8).
}

Peleu lembra ao filho que se Aquiles assim agisse, as gerações futuras the renderiam glórias. Tétis é outra voz a inspirar em Aquiles a contenção de ânimo: "A ira amaina que o rei Agamêmnon te inspira" (Il, XIX, 35). Fênix, o velho preceptor, que ajudara a criar Aquiles desde pequeno, amando-o como a um filho, diz:

\footnotetext{
"Doma, Aquiles, teu ânimo! Tanta aspereza não te vai bem. Os deuses mesmo são flexíveis!

E sua força é maior, seu honor, seu poder!" (Il, IX, 497-9).
}

Além dos pais e do preceptor, Aquiles recebe aqui e ali advertências, conselhos, sugestões dos companheiros de guerra. Odisseu lhe sugere que tenha paciência com os males da vida e lembra a Aquiles que, em sua trajetória nesse mundo, possivelmente 
haveria de enfrentar outros obstáculos maiores e, quem sabe, irremediáveis: "Mágoa hás de ter, futura angústia: mal já feito não se remedia" (Il, IX, 251-1). Outros companheiros também incentivarão Aquiles a "domar a ira": Ájax, Pátroclo, os Mirmidões $^{\text {xcvii }}$. Depois de tantas admoestações, o próprio Aquiles resolve suavizar seus sentimentos: "Amaino agora minha ira. Permanecer / nessa fúria obstinada não me convém (...)" (Il, XIX, 67-8). E, ao cantar ao som de sua harpa, Aquiles entoa as "gestas dos heróis" (Il, IX, 187-90), de certa forma, ouvindo as vozes da História, mesmo que não seja exatamente como o preconizado por Bakhtin.

$\mathrm{Na}$ Odisséia, o herói também é constantemente aconselhado, advertido, instigado, por outros personagens ${ }^{\text {xcviii }}$. A protetora-mór, Atena, dentre tantos conselhos, lhe diz: "(...) Contém-te e suporta tudo isso" (Od, XIII, 307) e "ora, convém refletir de que modo mais fácil consigas / os pretendentes punir (...)" (Od, XIII, 376-7). Alcínoo impele Odisseu a narrar, o que faz o herói repensar seu valor; Circe aconselha-o a se dirigir ao Hades e ordena que ele e os companheiros abandonem o sono, instigando-os à ação; Tirésias admoesta Odisseu a controlar a avidez, sugerindo que, dessa forma, encontraria êxito na jornada de retorno ao lar; Calipso recrimina a choradeira do amado e manda-o aprestar-se em construir a jangada; Telêmaco suplica ao pai que poupasse Fêmio, o artista.

Mais se assemelhando a Aquiles, Enéias é instigado, assessorado, aconselhado pelos pais, Anquises, o rei humano e Vênus, a mãe divina ${ }^{\text {xcix }}$. Outros intervirão no destino e caráter de Enéias. Quando em Cartago e, aparentemente, esquecido de sua missão, o herói recebe a dura admoestação de Mercúrio, para que se lembrasse da missão proposta pelos deuses, de fundar nova Tróia. Ao decidir-se por partir e continuar obedecendo a ordem dos seres celestes é Dido que tentará obstar-lhe a resolução, com duras críticas. Mais adiante, Nautes aparecerá com palavras de ânimo:

\footnotetext{
"Vamos: seja o que for, toda a fortuna

Co'o sofrimento superar se deve.

Tens, de origem divina, o Teucro Acestes:

Com ele te aconselha e te associa"

(En, V, 1018-19).
}

A Sibila diz: "Tu aos males não cedas: ao contrário" (En, VI, 142). E assim ocorrerá no conselho de Tiberino: "Não desistas da empresa; nem te assustem / os ameaços de guerra: as iras todas" (En, VIII, 58-9); bem como nos rogos de Mezêncio 
roga: "Refreia esse furor (...)"(En, X, 1218) Turno pede clemência: "Lavínia é tua, não prolongues o ódio" (En, XII, 1271).

Enfim, pelos tantos exemplos arrolados, sem contar muitos outros que se pode encontrar nas epopéias citadas, damo-nos conta de que os heróis eram constantemente impelidos, impulsionados, advertidos ou rechaçados através das interferências/vozes externas. E não poderia ser de outro modo, já que esses heróis espelham a natureza humana tal qual se mostra - nenhum homem vive apenas para si e seus atos dizem respeito a si mesmo aos outros, sendo, portanto, passíveis de louvor ou censura. O congraçamento de vozes nas epopéias, no entanto, se dá de maneira um tanto linear. Essas intervenções externas que objetivam alterar o comportamento dos heróis se restringem à narração: o narrador não nos conta como o herói trabalha interiormente o pensamento do outro, o que, de fato, aconteceria entre as pessoas. O narrador épico, sabemos, é um elemento exterior à mente de seus personagens.

Com o advento do romance, todavia, começou a imperar a transposição da diegese para a personagem, aspecto que abrange outro tempo que não o cronológico ${ }^{c}$. Bakhtin, entretanto, como estudioso dos fenômenos literários, foi além dos conceitos de monólogo interior, fluxo de consciência ou flashback, e percebeu nas personagens principais de Dostoiévski, que o que pareceria um processo voltado para dentro, através das divagações mentais, é, na verdade, voltado para o outro, o que ele denomina um grande diálogo com o pensamento desse outro $^{c i}$. Essa condição, dos pensamentos que aparentemente compõem um monólogo, mas que se qualificaria melhor como um diálogo manifesta-se de forma eloqüente em $O$ fiel e a pedra, romance já herdeiro de técnicas ousadas de narração. Nessa obra osmaniana, o protagonista ouve os conselhos, aplausos ou críticas negativas e reelabora essas ocorrências, gerando um dos aspectos da polifonia preconizada por Bakhtin. Percebemos, no entanto, que Osman Lins procura se aproximar das duas visadas, em relação ao tratamento das vozes interativas: tanto se assemelha do modo homérico de interferência na ação dos heróis, quanto ao exposto no romance polifônico. Bernardo assemelha-se a Aquiles, Odisseu, Enéias, no sentido de que outras personagens tentam arrefecer sua ira; mas é diferente desses heróis grecoromanos na medida em que o discurso do outro é-nos apresentado como fomentador de sua postura, em sua própria consciência. Somos apresentados aos angustiosos dilemas envolvendo as falas de outros, as quais, misturadas às opiniões da personagem, produzem considerável impacto, emparelhando-se, sendo repelidas ou gerando novos 
pensares $^{\text {cii }}$. Citamos alguns exemplos dessa pluralidade vocal que se manifesta de dois modos: a voz efetivamente concretizada e a voz rememorada.

A voz de Teresa se reveste de influência decisiva para Bernardo, através de ambos os modos: em tom audível e em casos extremos, peremptório, ou imiscuída às vozes dos outros, nas lucubrações mentais de Bernardo, tornando-se complementação ou contra-argumentação do discurso interno do protagonista. Os exemplos dessa função bipolar são vários, com o primeiro caso ocorrendo logo no início da narrativa. Bernardo e Teresa velam o filhinho agonizante. Uma torrente de pensamentos acomete Bernardo, fazendo-o relembrar fatos passados e questionar suas atitudes frente a esses:

"Bernardo refletia. Agira erradamente? Era justa a atitude que assumira, tudo para obedecer a uma exigência íntima, convicção que ninguém - Teresa, sim - parecia entender? E seria que ela realmente a houvera aceito e compreendido? Dentro na alma, no coração?" (OFP, 2).

Note-se que as palavras anteriores da esposa, ao assentir à decisão de Bernardo quanto ao emprego - demitir-se em razão das práticas desvirtuosas no ambiente de trabalho -, demonstravam a compreensão por parte dela, dos reais motivos que impulsionaram seu marido para aquele ato. Bernardo considera em pensamentos que Teresa fora a única a entender a força dos princípios morais sob os quais ele vivia. Mesmo com a anuência da cônjuge, porém, Bernardo não conseguia saber com certeza se fizera o melhor, o que se percebe na analepse ${ }^{\text {ciii }}$ do capítulo I:

"Decerto que um dia, mais cedo ou mais tarde, ele abandonaria o emprego, onde se sentia um pouco desprezível, e onde tinha certeza de que seu coração murchava, definhava aos poucos, como um preso. (...) Que Agripa Coutinho e seu tesoureiro, e seus secretários, fossem ladrões, dizialhe respeito? Não era ele que roubava o dinheiro arrecadado. E no entanto, se continuasse..." (OFP, 2).

Outro exemplo de um diálogo em forma de monólogo é a voz de Miguel entranhada nas perguntas de Bernardo. $\mathrm{O}$ esposo de Teresa relembra as palavras do outro e tenta entendê-las, bem como as razões que as provocam, pensando: "Qual seu padecer, desejaria Bernardo perguntar, qual a sua insônia, a sua dor mais forte? A doença, o irmão, a mulher branca?” (OFP, 27).

Mais uma inserção do diálogo com outras vozes aparece depois do ataque à plantação de cará e após a visita de Nestor, como sempre, insistindo na capitulação do 
barraqueiro, encontro pontilhado de veladas provocações. Bernardo demora a adormecer, imaginando o que poderia se passar pela mente da mulher:

"Ao deitar-se, Teresa apertou de modo significativo a mão de Bernardo. Nenhum falou, mas ele percebeu o quanto havia de encorajamento e afeição naquele gesto; e nas trevas do quarto (...) voltou o rosto para ocultar a expressão de mágoa. Teresa sofria, pensava na plantação, tentavalhe trazer uma paz que certamente não tinha. Ele também sofria (...)” (OFP, 199).

A voz do próprio Bernardo, dialogando com os deveres e direitos que norteavam sua vida se faz ouvir em debates mentais acalorados. Bernardo se sente muito mal pela violência que se mostra em suas ações ou pensamentos. O narrador diz:

“(...) às suas dores vinha acrescentar-se a lembrança do que chegara a entrever naquela tarde [a grande cólera que se forma dentro de si] (...). Que lhe sucedia realmente? Como entender e dominar os seus abalos, seus impulsos, até que ponto era justa sua maneira de agir, onde começavam os erros?" (OFP, 199)

Bernardo em suas lucubrações filosóficas adentra a origem do Mal. Ele tenta entender como, de um juízo meramente valorativo, o perfil de Nestor passou a germinar dentro dele, Bernardo, uma força destrutiva que poderia levá-lo de roldão:

"Com certeza, verdades e enganos se interpunham, enlaçavam-se, cada vez mais ele se ignorava. Sempre desconfiara de Nestor, não acreditava na virtude de seus atos; meses antes, porém, isto era apenas um juízo a mais. De que modo esse juízo, destacando-se dos outros, crescera, agravara-se, como chegara a se fazer tão grave? Desejaria cortar os alimentos de seu ódio, mas não sabia onde eles se encontravam. Se cultivasse a humildade... Mas como procurar uma virtude de que desconfiava, que nunca amara e tantas vezes desprezara nos outros? As virtudes. Cada um tem, nos próprios dons, a nascente de algum mal" (OFP, 199-200).

A frase "Se cultivasse a humildade... é o reflexo do que lhe aconselhara Miguel - "seu desmedido orgulho vai acabar com você" (OFP, 30). Bernardo reelabora essa tese, mas não consegue aplicá-la; por outro lado, sabe que há uma força externa no sentido de destruir sua vida: a gana de Nestor em querer dobrar seu orgulho a qualquer custo e auferir lucro com isso. No entanto, outra força, e essa interna, o torna apreensivo. Esse poder interno que assombra Bernardo é sua ira e a convicção desse fato o deixa mais atormentado do que a percepção do perigo que corre com a 
possibilidade de ataques externos. Nessa mesma noite, a voz de Teresa interceptando a violência, lhe vem à mente:

"Nestor Benício parecia obcecado pela idéia de amoldá-lo (...). Mas nada podia justificar as três tentações de que Bernardo se lembrava. Primeiro, fora o chefe do grupo ao qual abrira a porta. O furor crescia em suas mãos, Teresa dissipara-o. Logo houvera o estouro com o vigia, e quem sabe o que haveria sucedido, se as palavras da mulher não o salvassem outra vez? Mas fora o que sentira naquela tarde, junto de Benício que dera realce e um sentido perturbador ao que, agora, lhe parecia como que indícios de uma enfermidade. Com uma lentidão, uma força e uma constância de raiz, seu coração gerava um ser destruidor" (OFP, 200).

A recordação se refere a duas ocasiões anteriores em que Teresa impedira a concretização de ato violento da parte de Bernardo - e, nesse caso, falamos de enunciação literal. A primeira situação ocorrera por ocasião da visita noturna do estranho bando de Ubaldo, quando, esse demonstrara desconfiar do peso da balança e Bernardo perdera o controle, enfrentando ostensivamente o homem, sendo chamado ao juízo por Teresa:

“(...). Sem sentir, Bernardo se curvou sobre o balcão, e aproximou do chefe o rosto irado, de tal modo que o outro certamente ouviu sua respiração difícil. Sob essa cólera a ponto de romper-se, os olhos miúdos vacilaram. A mão livre de Bernardo moveu-se: tocava ainda o balcão, mas já havia uma corrente, um laço misterioso entre ela e a garganta do outro. $\mathrm{O}$ breve silêncio exalava qualquer coisa de particularmente sombrio, uma expectativa terrífica. Teresa sentiu-o, veio do quarto rápida, como se houvessem gritado e balbuciou à porta o nome do marido. No silêncio, o chamado parecera forte, imperioso. A mão deteve-se. Bernardo sentiu um estonteamento, sobreveio um alívio, como se lhe houvessem apertado o pescoço e agora o libertassem. Soprou um vento fresco, a chama estremeceu, alguns homens se adiantaram (o crescer de suas sombras) e insistiram para ser despachados.

- É bom, Bernardo. Eles precisam ir.

- Isso, dona. A gente vai pra longe, não pode perder tempo" (OFP, 186).

A segunda ocorrência se dera pouco depois do incidente com Ubaldo. Teresa evitara que o esposo se tornasse - quem sabe? - um assassino ao gritar seu nome no momento em que investia contra o vigia da fazenda que o assustara, tentando ocultar-se no jardim: 
"Sem dar importância ao rifle do gazo, agarrou-o pela camisa, à altura dos ombros e quase o ergueu do solo. Seu impulso era de jogar o homem ao chão, bater-lhe, esmagá-lo, esmurrar-lhe a cara muitas vezes, espezinhá-lo depois. Mal podia respirar, já que não via o rosto diante de si e trincava os dentes para não urrar.

- Bernardo! Bernardo!

Os gritos pareciam vir de longe e eram como um apelo de justiça. Xenofonte pressentiu que os dedos furiosos relaxavam a pressão e saltou" (OFP, 188).

A reação de Teresa a esses dois preocupantes episódios, reação expressa em palavras pronunciadas e também não ditas, calará profundamente em Bernardo e ressurgirá em outra noite. Veja-se o relato:

"Teresa adormecera. Encerrada no sono, naquela paz de que o seu ressonar constituía um sinal, a mulher era também mais frágil, com todas as carências que vem do desconhecimento; Bernardo sentia, junto a ela, ressoarem os próprios receios, sua perplexidade, suas indagações, como se o sono de Teresa aferrolhasse uma porta na alma dele - e nesse quarto fechado todos os rumores se adentrassem. E depois, via um engano, mais que proteção, em tê-la adormecida e nada lhe dizer, enquanto o desolavam as suspeitas daquela mácula crescente a se apoderar de sua alma. Não eram ele e a mulher como um ser?" (OFP, 200).

Observe-se a intensa comunicação não-verbalizada: os "próprios receios" e "indagações" ressoavam "junto a" Teresa. Pensando na porta perigosamente aberta ao grupo estranho e assustador de Ubaldo, Bernardo faz uma ligação interessante: o sono da mulher trancava a porta de um cômodo em que os "rumores", seus medos, suas angústias, seus questionamentos se resguardassem. A docilidade de Teresa, a calma que envolve seu ser, como um manto diáfano e que se traduzem em diálogos afáveis que troca com as pessoas, particularmente o esposo, seriam resultado [segundo Bernardo] de uma aura de inocência inerente e fragilidade que não deveria ser incomodada de modo algum. Por outro lado se pergunta: "Não eram ele e a mulher como um ser?" - agora remetendo ao texto bíblico de Gênesis: "E serão os dois uma só carne" (Gênesis 2: 24), e sendo uma só carne, como determinara o Instituidor do matrimônio, não deveria haver segredos entre ambos. A confiança, portanto, deveria reinar na sociedade conjugal, nem mesmo os pensamentos sendo acobertados. Se abrisse a alma à esposa, talvez a suavidade dela o ajudasse a reelaborar suas verdades: "Preciso te dizer, Teresa. Preciso te dizer tudo, para que tua bondade ou teu horror dissipe essa maldade”. 
O narrador descreve um ato que quase se completa de todo: "Estendeu a mão, que repousou no flanco da mulher. Teresa... Despertá-la, violar aquela paz, transmitirlhe sua angústia?" Por entre a dúvida de confidenciar ou não os anseios, ressurgem palavras e gestos de Teresa ante uma ação anterior:

"Ela se indignava com a morte das rolinhas, chorava ao tocar a penugem daqueles pequenos cadáveres cinzentos, pedira-lhe para nunca mais fazer aquilo. Como o olharia quando ele lhe dissesse que (...) contra homens (...) suas mãos se levantavam agora? Cruzou os braços, deitou-se de bruços, os dedos crispados sob as axilas. Sobre o punho direito, sentia o coração bater. Violência. Pensou nos seus inimigos novos, ao longe, confortados pela idéia de ter um homem a quem podiam odiar abertamente" (OFP, 200-1).

O episódio dos passarinhos mortos, lembrado por Bernardo e o estopim para a virtual reação da mulher, fora narrado anteriormente, quando do início da estada no Surrão. Teresa se sensibilizara ao ver os passarinhos mortos pela espingarda do marido, em caçada que esse fizera com Antônio Chá. Demonstrando aversão à atitude de Bernardo para com as pequeninas e vulneráveis aves, censurara-o:

"Teresa, ao receber nas mãos os pássaros mortos olhou para ele com uma expressão de espanto; deu-lhe as costas, aproximou-se da porta da cozinha, soprou levemente a plumagem cinzenta, por baixo da qual ardiam os ferimentos de chumbo, como rubis. (...). Levantou a película que descer sobre os olhos mortos: ainda brilhavam, um brilho tão triste.

- Mande Antônio tratar. Eu não faço isso.

- Por quê?

- Não tenho coragem.

- Você não mata galinhas? Não come carne de boi?

- Mas nesses passarinhos eu não tenho coragem de tocar. Não está em mim. Bernardo, não faça mais isso" (OFP, 66).

Assim, a atitude de Teresa, bem como suas palavras preenchidas de alta carga de repreensão e tristeza ante a morte provocada pelo marido; a ordem divina de não haver cisão de objetivos no casamento; as prováveis resoluções comportamentais dos moradores do Surrão - tudo compõem um conjunto interligado aos pensamentos de Bernardo, provocando consciência e alterando-a.

Um novo exemplo de diálogo bivocal ocorre depois do novo ataque à propriedade: o ataque traiçoeiro e fatal ao bezerro que se tornara quase um animal de 
estimação para Teresa. A opinião dos outros está implícita na maneira como Bernardo procede em relação ao enterro do bezerro:

"Queria terminar antes que o sol despontasse, para que não o vissem naquele serviço e lhe saboreassem a aflição. (...) e enquanto cavava com Antônio, lembrava-se do coelho de Lucinda e que uma noite os cães haviam morto. Como se pareciam as sensações de agora com as daquele tempo, enquanto abria a cova com sua mãe silenciosa ao lado, como se pareciam a sua revolta de menino contra os dentes dos cães e sua indignação de hoje contra a faca de um homem, sua raiva muda a um inimigo incerto, humano hoje, ontem canino (...)" (OFP, 204).

Veja-se que o silêncio da mãe de Bernardo é repleto de palavras e essas transmitem dor e um amargo sentimento de impotência ao menino que a ajuda a enterrar o animal. Agora, tem ao lado outra mulher silenciosa e magoada, que the transmite num discurso mudo sentimentos parecidos. Lucinda e Teresa, o bezerro e o coelho se misturam ao sentimento de ira que evolui dentro de Bernardo.

Bernardo imagina a possível fala de Teresa: "Ela sofria. E como devia sofrer! Melhor ir embora, quanto antes (...). Não ceder ao seu ódio (...)” (OFP, 206).

Mais um dado comprobatório da multiplicidade fônica acontece numa noite de agonia em que Bernardo rememora os incidentes contra seu patrimônio e pensa que Teresa, mesmo não se expressando verbalmente enquanto desperta, o faz durante o sono: "Ela não tem coragem (...). Esconde a sua fraqueza, mas desperta no meio da noite e me transmite essa convicção de que logo estarei morto ou escorraçado, vencido por Nestor" (OFP, 210-1). E o narrador continua, descrevendo o estado mental do esposo de Teresa: "Voltou a lembrar-se dos visitantes, de suas sombras nas paredes, do rosto miúdo do chefe". As imagens revisitadas, somadas às suas palavras e reações e acrescidas das reações dos outros, particularmente, da mulher, provocam novas inquirições: "Que se passava nos últimos dias, que mudanças se operavam nele, tão séria que não só as suas emoções, mas os próprios atos pareciam libertos, vinham cheios de um sentido irrevelado, que o atordoava?’. O narrador dá conta do gesto inconsciente de Teresa: "Teresa moveu-se, pronunciou uma frase ininteligível, sua mão aninhou-se no peito de Bernardo, como se buscasse refúgio". Bernardo traz o gesto de Teresa para o seu diálogo interior: "Estranho gesto o de Teresa, nascido de algum sonho, ou talvez em sonho algum e que o buscava" (OFP, 211), responde a esse gesto com um toque carinhoso e agradecido encetando diálogo com Teresa, tendo como base, as palavras 
mansas que sempre ouvira da mulher, palavras aliadas ao seu jeito tranqüilo de ser: "Teresa... Se eu pudesse te fazer feliz! Se pudesse te oferecer um pouco, só um pouco do que tu mereces. Seu eu pudesse...”. E o momento de tensa ternura é quebrado por mais uma recordação dolorosa: "Ele recordou o coelho morto pelos cães", lembrança que se junta à do bezerro, carregando, evidentemente, todos os sentimentos inferidos, e o faz concluir o desenho de seu atual estado: "Acordou com o pensamento de que era um homem acuado e de que precisava domar, dirigir as suas forças. A mão de Teresa deixara-o [grifo nosso]" (OFP, 211). Na continuidade da descrição do emaranhado de pensamentos, a grandiosa metonímia faz-nos apreender o que as palavras não precisaram expressar: "A mão de Teresa deixara-o". Bernardo sente que, embora apoiado pela esposa, somente a ele cabe domar a ira e enfrentar os cães.

Na mente de Bernardo, os discursos se cruzam, como já vimos, e não apenas os verbais, mas todo e qualquer tipo de texto. No caso acima, palavras, cenas, os pés metonimizados, pequenos gestos, tudo entra na construção de uma linguagem una - as conclusões que mentalmente elabora. Algo semelhante aparece na reflexão que acontece depois do tiro a que fora alvo:

“(...) De que poderia valer-se? A mulher! Estava ao alcance de sua voz e nunca lhe parecera tão cheia de poder e proteção. Se desatasse aquele segredo, a ira, a incerteza, o medo, confessasse tudo? Mas, ao mesmo tempo, ela nunca lhe parecera tão exposta: uma palavra e tudo o que ainda existia de tranqüilo em sua alma seria destruído. Era o silêncio dele que a protegia do terror. (...) E sua mudez aguçava, acerava o segredo: era cada vez mais árduo, mais pungente guardá-lo" (OFP, 231).

Pensando em matar Nestor e usando para tanto o parabellum, Bernardo tenta imaginar o que Teresa diria ou faria. Imagina que a mulher o reprovaria e se justifica, como se a questionasse:

“(...) se tivesse tempo de levar a mão à arma, arrastaria Nestor Benício consigo, entrariam duas redes na cidade, uma com o corpo de um homem, outra com os restos de um cachorro. E Teresa? Teresa era sensível, não suportava nenhuma violência. Mas, então, preferiria vê-lo morto?" (OFP, 271)

Não apenas a voz de Teresa, mas as demais vozes envolvidas em seu relacionamento com a mulher [a voz da sociedade, das tradições e deveres para com a família, numa releitura do Enéias virgiliano e sua piedade] obtêm seu espaço de 
emissão: "E os que dependem de mim? E Teresa? E o filho que esperamos? Não é preciso cuidar dos nossos, ampará-los, zelar por eles? Isso não me ajuda, isso me enfraquece" (OFP, 272).

No final, ao Nestor oferecer, acintosamente, preço pelo bezerro morto, Bernardo sente o sangue ferver:

\begin{abstract}
“(...) sofrera pelo cemitério, pela tocaia na estrada, pela chuçada no bezerro, pela plantação. A um sofrimento sucedera-se outro (...). Agora, as palavras de Nestor atingiam algum nervo dormente da memória e todas as feridas se cruzavam, queimavam de uma vez. Ele se manteve imóvel, atravessado pela rede lacerante - e sentiu que a mão direita pesava, que o parabellum guardado na gaveta puxava-a para baixo. Ah, Teresa, salva-me do mal, de todo o mal!" (OFP, 299).
\end{abstract}

Percebemos assim quão numerosas vezes Bernardo dialogará com Teresa, mesmo que não o faça em alto e bom som. Esse diálogo será composto por intromissões de outras vozes, formando um mosaico polifônico, conforme expressão de Bakhtin.

Outra voz é ouvida por Bernardo durante a narrativa - a voz da mãe, mesmo que essa seja apenas rememorada, já que, na ocasião em que se dão os fatos principais, Lucinda não mais existia. Essa voz retorna de quando em quando às lembranças do protagonista, não de forma gratuita, mas com nítida intencionalidade: ela coopta-se à voz do próprio Bernardo para ajudá-lo a assimilar e lidar com as dificuldades, as quais se lhe depara a vida. E Bernardo não se lembra apenas da voz audível de Lucinda, ou silente - inerte no barranco a esperar o filho ou contemplando-o, muda, ao lado da cama -, mas da voz moderadora de Cissone, intercedendo por ele: "Não bata nele, minha madrinha" (OFP, 63), cuja mensagem alcança êxito no coração ansioso da juíza punitiva. Tais enunciações permanecerão atuantes mesmo após a morte da mãe e da prima, e se manifestarão misturadas às suas próprias vozes, compondo um mosaico nunca entendido plenamente: manifestando-se plural ante sua maior crise, quando prestes a acertar contas com Nestor:

"Indagou, indagava e ao mesmo tempo desatava-se nele um amor claro, que o transpunha de sua condição para outra (...) onde a linguagem reinava no silêncio, as palavras dos lábios sendo inúteis. Não fizesse aquilo, não matasse Nestor, não manchasse de sangue as suas mãos" (OFP, 239). 
Essa voz provocará desconfiança do herói - "voz” de Lucinda ou suas próprias elucubrações? -, tão misturada à sua: "Aquelas palavras de Lucinda, quem sabe geradas no próprio coração de Bernardo (...) restituíam-no aos acontecimentos normais, ao uso seguro da vida" (OFP, 242). Ao perceber o cerco dos capangas de Nestor, a voz perderá sua força: "Sem saber por que, Bernardo começou a sentir-se outra vez inseguro, sem aquela misteriosa proteção em que acreditara (...) as mãos de Lucinda, a súplica, a promessa e sua própria fé em tudo isto pareciam distantes, mais distantes sempre e irreais" (OFP, 244).

A recorrência da imagem da mãe sobrenatural - inspirada em Aquiles e Enéias reaparece quando, percebendo-se inerme, sozinho e acuado pelos inimigos e por forças negativas internas, o herói anseia por alguma outra voz que lhe socorra, que lhe assopre o rumo da saída do negro túnel: "E que voz, que mão amiga podia vir, descer, livrá-lo da morte?" (OFP, 253). Essa voz desconhecida, uma voz de dentro dele, se fará no final:

"Como quem busca ouvir, mal desperto, um grito de socorro só existente em sonho, voltou-se (...) ele sabia que o chamado existia - real e enérgico -, embora tão fugitivo, que fora impossível apreender a sua verdadeira significação" (OFP, 303).

A impressão retornando um pouco mais à frente: "E a voz continuava insistente, semelhante à que rasga os pesadelos, rompe o jugo do sonho, desamarra. Mas o pesadelo não cessava. Emparedado no ódio, ele tomava a consistência da caliça" (OFP, 307). Olhando os cajueiros, lembra da mãe e pensa no que ela diria se ali estivesse:

\footnotetext{
"Afastou-se, devagar, subiu colinas, desceu-as, parando afrontado nas sombras, retomando a caminhada. No ponto mais alto do cercado grande, na linha dos cajueiros, deteve-se. Vinha das árvores floridas um cheiro de resina, de castanhas, que trazia de volta lembranças esquecidas: a mãe descascando os cajus vermelhos ou amarelos com uma faca de madeira, pondo-os num alguidar, fazendo-os secar ao sol numa peneira. Como estavam longe de pensar, naqueles dias, que ele os acabaria assim! Que diria Lucinda, perguntou, de novo, se estivesse ali?" (OFP, 271).
}

Essa pergunta se reporta a algumas das poucas frases de Lucinda e rememoradas pelo filho em toda a narrativa: a velada censura sobre o relacionamento entre os filhos [“- Discutiu com seu mano? Vocês brigavam tanto!" (OFP, 9)]; a advertência contra os predadores [“- Preste atenção a esses frades (...). Preste atenção, Bernardinho. Quanto mais bebem, maior é a sede" (OFP, 10)]; o incentivo a uma atitude mais amena em 
relação à vida [“- Por que você não fala, Bernardinho? Ria. Você não tem idade de ser tão ciente" (OFP, 12)]; o conselho para não se entregar a desafios incongruentes [“- Pois veja bem o que estou dizendo. (...) Não se meta a imitar essas façanhas. Você não é grande bastante para isso" (OFP, 61)]; a ordem para segui-la [“- Vista sua roupa. Vamos comigo" (OFP, 63)]; o louvor à tenacidade do filho, embora contrariada com a desatenção ao "conselho" ["- O que lhe salvou foi a sua firmeza, Bernardinho" (OFP, 63)]. Tais enunciações, de certa forma, se acham embutidas na pergunta: "Que diria Lucinda...?", um anseio de conselho, elogio, incentivo ou mesmo ordem, advertência ou censura.

Diálogo multivocal aparecerá nas reflexões de Bernardo advindas das palavras de Miguel. O rico latifundiário, e também empresário atacadista, cujos grandes objetivos de vida são fundados no lucro - supra-sumo da visão capitalista, portanto -, demonstrará indignação pelo fato de Bernardo ter jogado para o alto seu emprego, e a oportunidade de subir na vida. Ele faz eco ao que os outros dizem do assunto: "O que você fez foi estúpido. Não se deve fazer nada precipitadamente. Largar um emprego por capricho!" (OFP, 29). Bernardo responde, não aceitando plenamente o discurso do outro: “- Não foi por capricho. Nem foi por precipitação” (OFP, 29), mas Miguel continua: “- Desafiar um homem na hora que ele sobe, senhor! O Posto Fiscal não é propriedade de Agripa Coutinho. Não é propriedade do Prefeito" (OFP, 30). E diz:

“(...) Você fez como poucos, entende? Você, a bem dizer, não era nada; e mandou para o diabo segurança e acomodação. Muita gente graúda, de arca abarrotada, era contra Coutinho e já está com ele. É isso que dá raiva, Bernardo. É por isso que lhe odeiam e têm inveja. Todos sentem, essa cambada, que você é maior do que eles. E pode ficar certo: por enquanto, você não tem oportunidade aqui. Eles têm de provar, esse pessoal de Vitória, que você está errado. Querem ver seu castigo, sua queda. E isso tem de vir, Bernardo, se você não mudar. Só então eles vão dormir sossegados. Um homem pode agüentar que você lhe roube tudo. O que não suporta é ver ninguém abandonar uma riqueza. Ou uma segurança. Nada no mundo enfurece mais. Eles devem ter ficado contentes, com a morte do seu menino.

Fez uma pausa, os dentes cerrados. (...).

- Eu mesmo - e sou dos melhores -, quando soube do que você tinha feito... Tive raiva. Senti que não era homem para fazer o que você fez, entende? Mas isso já passou. Você vai morrer sem nada, seu desmedido orgulho vai acabar com você, mas eu queria tentar alguma coisa. Quero fazer algum bem a quem merece, no tempo que me resta. E também o mal que for necessário. A quem merece" (OFP, 30).

Desse inflamado discurso, pinçamos algumas observações: 
- Miguel é o representante da consciência coletiva - o povo: "É por isso que lhe odeiam e têm inveja (...) Eu mesmo (...), quando soube do que você tinha feito... Tive raiva". Os ricos eram contra o fiscal, mas assim mesmo, submeteram-se à corrupção: "Muita gente graúda, de arca abarrotada, era contra Coutinho e já está com ele".

- Miguel também sente inveja ou indignação em relação ao ato de Bernardo, ou a ele mesmo: "É isso que dá raiva".

- Miguel não odeia, efetivamente, Bernardo, mas sente raiva de seu ato: "É por isso que lhe odeiam". Enquanto os outros tentavam provar que Bernardo estava errado, não o ajudando em nada, Miguel, mesmo com raiva, o apóia e oferece um emprego: “(...) por enquanto, você não tem oportunidade aqui”; “(...) mas eu queria tentar alguma coisa. Quero fazer algum bem a quem merece, no tempo que me resta". Os outros aplaudiam cada evento de desgraça - pois esses incidentes corroboravam sua tese - a destruição iminente de um audacioso: "Eles devem ter ficado contentes, com a morte do seu menino".

- Miguel adverte: a queda viria se Bernardo não mudasse: "Você vai morrer sem nada, seu desmedido orgulho vai acabar com você, mas eu queria tentar alguma coisa".

- As pessoas podem suportar tudo (roubo), mas não suportam ver o outro desperdiçar chances de enriquecer, porque é o que todos procuram; se Bernardo desperdiçava as oportunidades, estava sendo diferente; e ninguém suporta o outro diferente - um espelho que não reflete a mesma imagem: "Um homem pode agüentar que você lhe roube tudo. O que não suporta é ver ninguém abandonar uma riqueza. Ou uma segurança. Nada no mundo enfurece mais".

- Auto-avaliação de Miguel - ruim, mas nem tanto, pois capaz de perceber a inveja em seu âmago: "Eu mesmo - e sou dos melhores -, quando soube do que você tinha feito... Tive raiva. Senti que não era homem para fazer o que você fez, entende?"

- Contudo, Miguel havia conseguido enxergar claramente os verdadeiros sentimentos, superar a inveja e admitir a si mesmo a falta de coragem para se por no lado certo: "Mas isso já passou". 
- Certamente, a morte do filho de Bernardo o comovera, ao contrário dos outros e isso se subentende nos dentes cerrados.

- Tudo havia passado - a raiva e inveja de Bernardo -, mas a constatação de que o procedimento não era o melhor prevalecia. "Você vai morrer sem nada”.

- Miguel se instaura como um juiz vingador: vai dar o prêmio a quem merece e a punição a quem for desmerecedor: "Quero fazer algum bem a quem merece, no tempo que me resta. E também o mal que for necessário. A quem merece".

O discurso de Miguel recheado, como bem constatamos, do discurso dos outros, é replicado mentalmente por Bernardo:

"Bernardo ouvia-o ainda, num atordoamento, um aperto na garganta. Sabia um pouco do que trazia no sangue: amar em silêncio, dedicar-se por inteiro, querer com intensidade; muitas fraquezas, nunca adormecidas, sempre em luta à espera de um descuido, para saltar sobre ele e governá-lo; isto e ainda, como um instinto, o gosto das viagens. Compreensível que um ninguém como Antônio Chá o admirasse (...). Porém, Miguel Benício, com todas as suas terras e animais e ouros, perdesse todo pudor e o engrandecesse, fronte a fronte, era possível entender? Ou será que haveria, nas palavras de louvor, uma intenção cruel?"' (OFP, 30)

Bernardo surpreende-se ao ouvir as palavras de Miguel; afinal, ser admirado por um ignorante e pobre, que não entendia muito bem os fatos da vida, era aceitável; mas ter o caráter apreciado por um rico...? Por outro lado, duvida da intencionalidade do discurso, lendo nele, talvez, outras frases:

"Miguel falara de orgulho. Não era orgulho, porém. Ou seria? Tinha desprezo pelos homens que se curvam, não queria transformar-se em um deles. E isto era tão fácil, o mal era tão pródigo! Dir-se-ia que no mundo, só ele oferecia recompensas e que só o bem impunha sacrifícios" (OFP, 32).

O esposo de Teresa remói o discurso de Miguel, para elaborar suas conclusões, que, a bem da verdade, são inconclusas, pois continuará sem obter certeza quanto ao caráter do sentimento que acalenta no íntimo. O sentimento que Miguel classificara como orgulho seria isso, ou não? Um pouco mais adiante nessa conversa, ao manifestar- 
se Miguel tão destituído de confiança nas pessoas, tece amargas considerações sobre a vida:

“- Não tenho mais ambições, nem mesmo alegria. Uma luta perdida, a minha vida. O que vale, é que não me restam senão uns poucos anos, talvez uns poucos meses.

- O senhor vai viver muito.

- Para quê?” (OFP, 31)

O narrador, então, introduz o dialogismo no diálogo aparentemente composicional:

"Bernardo contemplou, lá fora, as pedras faiscando ao sol. Como ia longe o tempo em que passava horas no alpendre, atento às alucinações de Marinheiro, sonhando com montanhas esplendentes, onde o ouro saltava à flor da terra! Hoje estava certo de que tais montanhas não existiam. Mas passara a acreditar que a vida - coisa difícil de explicar - tinha um certo brilho de ouro, não obstante seu negror. Um certo brilho que os olhos não viam" (OFP, 31).

Na reflexão, retorna a lembrança de sua casa - o alpendre, palco das conversas com Marinheiro, o que fora exposto anteriormente na pontuação sob o viés da anacronia $^{\text {civ }}$, forte pendor de organização de tempo na narrativa:

"Travara amizade com um falsário por nome Marinheiro, que lhe ensinara a consertar relógios, a pretexto de domar-lhe a paciência. Quase todos os dias se encontravam, passavam horas e horas sentados no alpendre, falando em minas de ouro e na pedra filosofal" (OFP, 9).

Observe-se que Marinheiro era o "falsário", um narrador que contava dos tesouros - as montanhas "esplendentes" e alimentava os sonhos de Bernardo. O discurso de Marinheiro, mesclado já às histórias de outros sonhadores, gera conclusões importantes para Bernardo e se mistura ao discurso de Miguel: Marinheiro, um miserável, sonha com um ouro que não existe; Bernardo aprende a enxergar outro tipo de "ouro", o valor da vida - o ouro que não se vê [em diálogo com a ciência da geologia, conclui que, como no caso do ouro literal, por baixo do negror da pedra há a valiosa pepita]; Miguel, com todo o seu ouro concreto, palpável, não via esse outro ouro. A conclusão verbalizada por Bernardo é: “- A morte é tão ruim!”. Essas pontuações ideológicas no diálogo de Bernardo se aproximam do que Bakhtin observara 
no romance de Dostoiévski, de que a cosmovisão dos outros personagens se cruza com a dos personagens principais, inclusive sendo contaminada por tudo a sua volta, tudo provocando e polemizando as idéias do herói ${ }^{\mathrm{cv}}$. Novamente encontramos nas reflexões de Bernardo uma espécie de discurso bivocal na lembrança do pedido de Miguel para que Bernardo ajudasse a eliminar o rival. Bernardo se lembra do discurso do patrão e se angustia por não ter exposto razões para uma mudança de idéia:

"No caminho, a mágoa que nascera da conversa começou a doer. Triste discussão. Miguel estava irritado, estava fora de si - isto era um fato, era uma atenuante - mas tudo destoara tanto do que ele sempre fora. Claro que ninguém é santo e uma complicação daquela com a mulher endoidecia um cristão. Mas um homem que auxilia outro, que lhe facilita os negócios, faz-lhe confidências e até pensara naquela história das compras simuladas, um amigo assim ... 'Eu devia ter sido categórico. Duro - se acusou. Devia ter repelido com mais força.' Palavras que cresceram, quando ele admitiu, com espanto e humilhação, a existência de um desprezo escondido, não nos olhos, nas palavras, ou nos gestos de Miguel, mas dentro dele. Possível seria? Não se manda chamar tão longe, às pressas, uma criatura a quem se menospreza, para contar segredos como aqueles" (OFP, 90).

Note-se que Bernardo pesa os argumentos de Miguel e defende-o: "Claro que ninguém é santo (...)" e até um "cristão" poderia ser tentado a quebrar as leis do cristianismo - um dentre os dez mandamentos: "Não matarás" (Êxodo 20: 13), mediante a "complicação daquela com a mulher". Mas Bernardo se culpa, deveria ter relembrado ao amigo a posição de um cristão, as conseqüências dos atos orientados para o outro. Os olhos, as palavras, os gestos de Miguel, lembrados e redesenhados, mostram a ele quem é o ser mais desprezível.

Mais um exemplo do dialogismo surge na conversa de Bernardo e Bindinho, e na extensão da mesma. Depois da morte de Miguel e após a conclusão de que essa ocorrência fora um crime, constatação verbalizada e recebida com zombaria por uns e agressividade por outros, Bernardo sai do armazém, e, conforme o narrador, meio sem destino: “(...) passou a perna no burro, se afastou sem rumo” (OFP, 96-8). Mas, veja-se a seqüência da narração:

"Seguiu pela frente do açougue, tomou a direção do Pátio do Mercado, passou pela mercearia de Nestor, cruzou a Bomba de Magalhães, entrou na Rua do Comércio, parou ante o Bilhar, desceu. O salão estava deserto, àquela hora. Mas o preto Bindinho ali estava, lendo o jornal da véspera, o chapéu de massa na cabeça, como sempre. Fora dos poucos que lhe emprestara dinheiro, meses antes. Não muito: tinha família e ganhava um ordenado modesto no Bilhar. 
- Seu mano! Como vai o Surrão?

- Vai como pode. E você por aqui?

- Devagar, levando minha cruzinha de cajá.

- Viu o fim de Miguel?

- Mas que coisa, Bernardo. Morrer assim!

As cadeiras estavam espanadas, o piso de mosaico bem varrido, lustrosos os pés descomunais das três mesas. Bindinho fitava-o com atenção, aquele olhar bondoso e lasso que adoçava o rosto negro.

- Você parece cansado, seu mano.

- Trabalho muito. E hoje, essa morte...

- A vida é assim mesmo, Bernardo. Dia mau, dia bom. É conformarse. Ainda acerta a pegar no taco?"

- Andei pegando foi uma espingarda, fazendo umas caçadas. Mas a mulher... Ela não pode ver um passarinho morto.

- Nunca mais dei um tiro - queixou-se Bindinho. Neste serviço... Você sabe, aqui não tem dia santo. E às vezes faz cada domingo, bom de passarinhar!" (OFP, 96-8)

Podemos observar desse excerto, vários aspectos. O narrador diz que Bernardo saíra sem rumo do armazém de Miguel; no entanto, não há descrição de um trotear indeciso, ao contrário, Bernardo segue, sem desvios, o trajeto para o Bilhar de Bindinho. Se a personagem vagava sem uma intenção consciente, inconscientemente, visava certeiro o destino, na ânsia de ouvir uma palavra amiga, enquanto aguardava o horário do sepultamento de Miguel. E Bindinho estava lá - o chapéu sendo um índice de que era o mesmo e que não mudara de atitude para com Bernardo, como os demais moradores de Vitória. Ao contrário, Bindinho, na sua escassez de recursos, fazia parte do exíguo grupo de pessoas que haviam apoiado financeiramente a Bernardo, nas agruras pelas quais passara após a demissão do emprego. Bindinho é descrito de forma indireta, como um funcionário correto, zeloso: o estabelecimento comercial estava impecável, denotando o compromisso do empregado com suas responsabilidades: o chão e os móveis mantinham-se limpos e ele, pronto a receber os clientes. $\mathrm{O}$ rapaz não era um ser isolado, alienado dos problemas a sua volta; ao contrário, interessava-se pelo que acontecia ao seu redor. Em lugar de entregar-se ao ócio advindo da falta de clientes àquela hora, procurava informar-se, lendo jornal, mesmo que do dia anterior. Bindinho efetivamente - e "como sempre" - dispensa total e sincera atenção a Bernardo, "fitandoo com atenção", tendo o olhar carregado de bondade, serenidade e doçura. A atitude dócil, conformada diante da vida é expressa nas palavras: “A vida é assim mesmo (...), Dia mau, dia bom. É conformar-se”. Para suavizar a ansiedade de Bernardo, procura distraí-lo de seus problemas. Ao final da frase que denotava sua submissão ao desenrolar dos fatos da vida, oferece um jogo de sinuca. Bernardo diz que tentara caçar, 
sendo frustrado pela sensibilidade da mulher e o negro, para relativizar, dissera que ele também não podia se divertir nas caçadas em razão do emprego. Bernardo conclui em pensamentos: "Procura confortar-me, refletiu Bernardo, desviar a conversa. Preto bom, sem o desassombro de Dominicano, porém de coração mais brando". O esposo de Teresa tentava expressar sua tristeza ante os fatos da vida, mas Bindinho lhe apontava para a flexibilidade: nem tudo é como se quer, ele também tinha que se curvar ante as circunstâncias. As palavras de Bindinho ecoam na mente de Bernardo. Ele se recordará delas e as rechaçará:

"Subia a Rua do Meio. Lembrava-se da sua vida antiga, de Álvaro e Cissone, de Lucinda e de seus bichos miúdos. Muitas águas correram sobre mim, estou ficando velho, caio sempre, volto sempre, recomeço. 'A vida é assim mesmo, dia bom, dia mau; é conformar-se.' Não.

Sem precisão, esporeou o burro". (OFP, 98)

Note-se que Bernardo repete as palavras de Bindinho, as mesmas, repletas da cosmovisão desse, mas Bernardo replica: "Não" e a força dessa negativa, a carga de agressividade que ela contém aparece no gesto de esporear sem necessidade o burro. A psicologia talvez dissesse que Bernardo estaria com o gesto atravessado esporeando o destino que se lhe apresentava hermético, lutando para reverter essa condição.

Acrescendo-se aos tantos exemplos de voz que participa concretamente e depois se imiscui nos pensamentos do herói, provocando reação, é a de Nestor Benício. Observemos como o narrador a apresenta, em um dado segmento da narrativa, bem como adere a essa voz um caráter autoritário, pouco confiável e mesmo, cruel:

"A voz de Nestor, prometedora e confidencial, deslizou no silêncio:

- Você não vai embora. Sou um continuador do mano. Sei que seu trabalho é muito e vou dar-lhe um estado mais impante. Nada de misérias. Favor de mão fechada? Minha lei é outra, os alforjes abertos. O homem cresce, Bernardo; a altura do homem são os seus poderes. Você era um braço, vai ser mais do que isso. É promessa e conselho" (OFP, 102).

A voz, como no caso de outras, é inserida no arsenal de pensamentos de Bernardo:

"Ficou olhando o bamburral, (...) o coração diminuindo outra vez. Indeciso, desceu os degraus, bateu a porteira, afastou-se, entrou no cercadinho. Afagou o lombo de Princesa, sopesou-lhe o ubre, olhou para o bezerro que saltava. Crescia a olhos vistos. E a plantação de cará, na encosta do monte, verdejava. Suas posses cresciam. Ter-se-ia enganado com o irmão 
de Miguel? Que existiria de verdadeiro, nas suas tantas palavras? Poderia continuar no Engenho, vendo aumentarem seus bens? O burro comia, os flancos lustrosos à sombra da manjedoura. Os olhos enormes de Miguel, fitando-o com tristeza sob o chapéu branco, entre os cavalos" (OFP, 104).

O excerto acima é rico em possibilidades de interpretação. Apreciaríamos arrolar alguns elementos de uma leitura analítica, enfatizando, evidentemente, seu potencial dialógico em que linguagem verbalizada aliada ao espaço contribui para polemizar o herói. A frase: "Ficou olhando o bamburral", ou seja, demorou-se contemplando, nos leva a entender que Bernardo não olhou simplesmente para o arvoredo, mas deteve o olhar, apropriando-se mentalmente do belo monumento natural - algo que tinha despertado sua atenção desde que levava os burros vendidos a Miguel, o que testifica o excerto:

"Depois levava-os [os burros], soltava-os no cercado, demorava-se um pouco no Surrão. Tinha a sua beleza, o Engenho, agora de fogo-morto. Açude, regato perene, muitos cajueiros, cana, filas de eucaliptos. As redondas elevações. O espesso bamburral, ao longe, em frente ao barracão" (OFP, 28).

O bamburral era, pois, agradável aos olhos de Bernardo, era uma espécie de símbolo do Surrão e sua pujança. Mas, enquanto demorava-se observando o bamburral, Bernardo sentia "o coração diminuindo", a angústia corroendo. Outra imagem representativa nos é ofertada com a seqüência de ações de Bernardo: ele "desceu os degraus", "afastou-se", "bateu a porteira", expressões que indicam um voltar-se para si mesmo, deixando o mundo para trás. O destino é o "cercadinho", onde seus bichos ficavam. Lá ele carinhosamente toca a vaca, constatando o ubre repleto de leite vindouro, vê o bezerrinho que se desenvolvia a contento e pensa na vicejante plantação de cará. A conclusão é de que estava prosperando: "Suas posses cresciam", o que correspondia aos planos de Miguel para com ele: "Eu lhe empresto dinheiro, você compra uns bois (...) o que você quiser, está em suas mãos" (OFP, 31). A luta de Bernardo é intensa e, ele tenta relativizar. Olhando os animais e lembrando-se da roça, pergunta-se a si mesmo: “Ter-se-ia enganado com o irmão de Miguel? Que existiria de verdadeiro, nas suas tantas palavras? Poderia continuar no Engenho, vendo aumentarem seus bens?" Bernardo está remoendo as palavras de Nestor, juntando-as às de Miguel e somando tudo às suas ambições. Os olhos continuam percorrendo os bichos e param no burro que se alimentava - uma representação da rotina mansa e ideal que Bernardo não 
desejava alterar: "O burro comia, os flancos lustrosos à sombra da manjedoura". No entanto, à cena bucólica, uma imagem se imiscui: "Os olhos enormes de Miguel, fitando-o com tristeza sob o chapéu branco, entre os cavalos". A imagem dos olhos de Miguel entre os cavalos remete ao ex-patrão, duplamente. Em primeiro lugar, porque o burro fora-lhe dado pelo outro, em sinal de amizade e consideração. Bernardo, efetivamente, precisaria de um meio de transporte próprio nas idas e vindas ao Surrão e do mesmo a Vitória, para o acerto de contas. Todavia, o barraqueiro estava sem condições de pagar, ao menos de imediato, por um cavalo, mula ou burro. Miguel, gentilmente, levara Bernardo a escolher um burro e o ofertara. Bernardo sentira-se grato e enternecido com o gesto:

"E ao falar de seu burro, não o fazia apenas como dono: o animal fora presente de Miguel. Isto acrescentava-lhe à pisada, à resistência, qualidades novas; achava que valia mais por isto. E não lhe parecia que, sendo um presente, estava impedido de negociá-lo. Antes; fazer uma boa transação com a montaria, trocá-la vantajosamente por outra ainda melhor, seria a seu ver um modo de honrar e acrescentar o gesto do amigo" (OFP, 122).

Em segundo lugar, o burro [já que presente de Miguel] lembra a Bernardo a confiança que o ex-patrão depositara nele e essa se ligava à integridade que o próprio Bernardo sabia ser seu prumo. Ao efetuar comércio com o falecido, implícito pacto de confiança caracterizava as negociações: Bernardo era honesto nas transações, nunca atropelando as regras de uma boa venda: ia até o armazém da cidade e calmamente oferecia os cavalos, em apresentação franca, nunca escamoteando prováveis imperfeições: "sentava-se, pintava os animais para Miguel Benício, chamava-o para vêlos. Miguel não ia nunca, aceitava a descrição, botava preço (...). Bernardo respeitava a sua boa-fé e nunca embelezara os animais naquelas transações" (OFP, 28). Os olhos de Miguel apareciam revestidos de tristeza, remetendo à desesperança e fastio da vida que lhe eram peculiares quase ao fim da vida: "Fui um homem confiante, não sou mais. Tomo precauções para não ser, isso me entristece. Nasci para a fidelidade, mas onde é que vivo? Num mundo de artimanhas" (OFP, 29). A imagem dos olhos de Miguel, portanto, faz balançar o senso de prosperidade e a tentativa de relativização das ações e palavras de Nestor. Bernardo se pergunta:

"Que verdade haveria - perguntou - nas palavras de Nestor? Por que viera tão cedo, por que ostentava amizade? O que estou - acusou-se é 
procurando enganar-me. Nestor é como se tivesse muitas bocas, nos braços, no peito, nas mãos, prontas a morder e todas venenosas. Como finjo ignorar esta verdade? Que está havendo comigo? Falara a Teresa, pouco antes, da conversa com Nestor Benício. E sentira, no seu silêncio, uma sombra de censura. Injusta, porém: nada podia fazer" (OFP, 104).

Agora, a situação se modifica: as muitas bocas, no braço [que, sabemos, representa a força, o poder camuflado pela proteção anunciada], no peito [remetendo ao coração e aparentando bondade, acolhimento], na mão [o gesto que agarra ou afasta, o poder $]^{\text {cvi }}$. Ou seja, as muitas bocas lembrando um híbrido de polvo sufocante e medusa venenosa. As muitas bocas de Nestor, dizem respeito à diversidade de discurso... E Bernardo tenta dialogar com todas as bocas, todos os discursos imersos no discurso de Nestor. A conclusão se faz: todas as bocas são venenosas, ou seja, todos os discursos apreendidos por Nestor são distorcidos a fim de que logrem atingir o alvo. Nestor citava as ações do irmão [benfazejas por si só] e prometia repeti-las, ampliando-as [da ação boa chegaria a uma ação sórdida, de domínio autoritário e cruel]. Percebemos o intenso diálogo de Bernardo consigo mesmo: ele se pergunta que "verdade" poderia existir nas palavras do irmão de Miguel; mas, veja-se que nesse diálogo estão contidas tantas outras vozes - de Nestor, do mundo que rodeia o protagonista, de Miguel, dele mesmo... E a voz interlocutora acusa Bernardo: "Como finjo ignorar esta verdade? Que está havendo comigo?" Bernardo insere no diálogo a expressão da mulher: "E sentira, no seu silêncio, uma sombra de censura". Teresa não falara absolutamente nada, mas seu calar era repleto de mensagens. E Bernardo interpreta as palavras no silêncio - palavras de censura. Ele dialoga com essas palavras e se defende veementemente, embora para si próprio, o que indica a condição adversativa da frase após o valor que atribui à "sombra de censura": "Injusta, porém: nada podia fazer". O narrador que se mistura aos pensamentos de Bernardo diz, inclusive, repetindo a frase de Nestor, levando a mais um questionamento:

"A confiança nas boas intenções de Nestor, se não tinha firmeza, tornou-se ainda mais frágil - ou deixou de existir. Os objetivos do outro eram avançar, colher tudo ao seu alcance, estender-se. A qualquer preço, contra todo escrúpulo. A altura do homem são os seus poderes. Por que então, fizera uma viagem, sentara-se na sala, falara tanto tempo, o chapéu negro na mão?" (OFP, 107).

Sabemos que esse diálogo produzirá seus frutos... Bernardo voltará a se por do lado da lealdade as suas normas de vida. Mais adiante, ao Nestor cobrar aluguel do 
barracão, atitude autoritária que se opõe à de Miguel e ainda desperta o orgulho em Bernardo, o discurso de Nestor será repetido mentalmente e rechaçado com veemência:

"Pagaria a Nestor, cederia, ganharia tempo. (...). E quem sabe se de tudo que pudesse fazer, se entre todas as reações possíveis, não era justamente isto - ceder, pagar - o que Nestor Benício desejava menos? Como saber se ele, conhecendo-o, não visava a sua recusa para obrigá-lo a sair e denegri-lo depois?

Ainda havia o recurso de expor suas razões e pedir a Nestor que reconsiderasse a cobrança. Mas que fazer, se este exigisse provas de que Miguel dispensara os aluguéis? Pois era certo que faria essa exigência, como era certo que sabia tudo e que decidira esquecer para ofender. E também podia ser que antecipasse o gosto de escutá-lo, magnânimo, botar-lhe a mão no ombro, dispensar-lhe a divida. 'Minha regra é outra, os alforjes abertos'. Alforjes abertos. Os alforjes da maldade" (OFP, 147).

Relembremos que as palavras de Nestor estão citadas acima:

"Você não vai embora. Sou um continuador do mano. Sei que seu trabalho é muito e vou dar-lhe um estado mais impante. Nada de misérias. Favor de mão fechada? Minha lei é outra, os alforjes abertos. O homem cresce, Bernardo; a altura do homem são os seus poderes. Você era um braço, vai ser mais do que isso. É promessa e conselho" (OFP, 102).

Essas palavras vão ser remoídas nos pensamentos de Bernardo, provocando novas conclusões, como se vê. Ao final, aguardando o acerto de contas, Bernardo repetirá, novamente, a voz de Nestor, nas divagações introduzidas pelo narrador:

"Sentou-se no banquinho, olhou as mãos. Depois de tantas horas, conseguira dormir alguns minutos, quinze ou trinta. Fora o bastante para que certos fios se ligassem, desvios do sentir e do pensar fossem notados, retificados, para que ele visse e agisse melhor. (...) e Nestor, se quisesse matá-lo, haveria de mandar algum menino? Queria rir do seu medo, obrigálo a fugir, gozar a sua humilhação: por isto viera de tarde, insistente, oferecendo apoio. 'Você não quer meu amparo e quer ficar. Mas só pode ficar debaixo da minha guarda.' Pensava que na hora da aflição... Mas eu recusei - pensara. Eu recusei. E sentira-se agradecido àquele outro Bernardo, tão vulnerável às intenções do inimigo - uma vez que desconhecia - e que reagia como se nada ignorasse" (OFP, 284).

O discurso de que Bernardo se lembra, acontecera por ocasião da última visita de Nestor. Esse sugerira a Bernardo que permanecesse no Surrão, mas, diante do silêncio de Bernardo, ameaçara:

\footnotetext{
“- Por que você não fica, rapaz?
} 
(...)

- Não quer ficar. Pois eu não escondo nada, ponho as cartas na mesa. Você tem um inimigo pela frente, se for embora. (...) Mas veja: você não quer meu amparo e quer ficar. Mas só pode ficar debaixo de minha guarda. Já lhe fizeram mal, fizeram muito mal e podem fazer mais. E quem sabe o que pode vir? Mas se eu lhe der autoridade, se lhe der potência, essa canalha vem lhe beijar os pés, entendeu. Eu não volto a oferecer, esta é a última vez: aceite minha proteção" (OFP, 235).

Notemos que Bernardo ouvira o discurso, sentindo-se "irritado, fatigado, triste" e com os olhos no bamburral, mais uma vez, a beleza natural contribuindo para oscilar o prato da balança. Os dois Bernardos lutando interiormente, pesando as palavras de Nestor, conjecturando. Agora, entretanto, Bernardo se regozijava por não haver cedido às falsas promessas.

A voz de outra personagem também adentra à consciência de Bernardo: a de Xenofonte, o vigia. E isso se dá por conta do diálogo efetivo ocorrido por uma reação do vigia a uma decisão de Bernardo. Veja-se a explicação do narrador, antecedendo a troca de palavras ásperas:

“(...). Como recusasse a Xenofonte - pretensão absurda - fiar-lhe mais do que lhe permitia o seu salário, o gazo ameaçou, sem nada do respeito que sempre demonstrara:

- Pois eu hoje de noite arranco um quarto do seu bezerro.

- Que vigia é você, que quer fazer o papel de cangaceiro?

- Quero conversa? Arranco um quarto e acabou-se.

- Se você tocar no bezerro, quem lhe arranca o quarto com um bala, sou eu. (OFP, 123)

O narrador descreve as demais expressões que se acrescentam às ameaças de Xenofonte: “(...) ele afastou-se enrolado no capote, aos berros, como se nada o houvesse divertido tanto quanto a discussão”. E a atitude de Xenofonte irá gerar uma questão: “Imitaria Nestor?”. O narrador continua descrevendo as ações de Bernardo - e essas, motivadas pelas palavras de Xenofonte - misturando narração ao diálogo interior de Bernardo:

"À hora de deitar, Bernardo apanhou o parabellum, pôs o chapéu, vestiu uma camisa de baeta. Lua não havia e os ventos de agosto sopravam com dureza. No cercadinho, o chocalho da vaca ressoava, límpido. Ficar de guarda sempre, era impossível; mas Xenofonte não marcara para aquela noite? Talvez que o desgraçado, não o encontrando, dobrasse o atrevimento. 'Eles não fazem comigo o que andaram fazendo com Ramalho.' E pensou, pela primeira vez, que, se um homem multiplica seus haveres, crescem poder e meios de mandar nos outros, mas sua vulnerabilidade também cresce. 
Sendo o enriquecimento, de certa maneira, substituição de servidões. E como adivinhara o vigia que, naquela hora, o bezerrinho era um de seus pontos mais sensíveis? Surpreendera Teresa no cercado, o braço estendido, o bezerro ante ela, dócil, tomando dos seus dedos talos de capim? Lambendolhe o vestido, a mão, inclinando a cabeça, como um bicho caseiro, aos seus afagos? Teria visto isso e descoberto, no rosto da mulher, sua ternura, seu amor infantil pelo animal". (OFP, 123)

No monólogo/diálogo de Bernardo imiscuem-se os elementos naturais: ausência de luar, "ventos de agosto", "chocalho da vaca" todos contribuindo para as indagações e hipóteses do protagonista. Bernardo pensa em Ramalho, o empregado que fraudava o patrão, trazido à tona pelo discurso de Miguel: "Pois o camarada estava me roubando" (OFP, 29). E filosofa: quanto mais bens, mais "vulnerabilidade".

Vale salientar que a voz da personagem surge diante de nós como um resquício da voz autoral, que embora presente, como nos romances monológicos, faz-se mesclada à do protagonista, não prevalecendo dentre as demais, como verdade incontestável, mas instaurando-se como simples dedução- característica das obras dialógicas ${ }^{\text {cvii }}$.

\section{Vozes internas}

Na Ilíada e na Odisséia, os heróis ouvem seus thumos ${ }^{\text {cviii }}$ - a voz interna e independente. Por exemplo, Zeus diz a Hera que iria liberá-la para agir como desejasse, em relação à guerra de Tróia, opondo-se ao seu thumos (Il, IV, 43 - traduzido por contra-coração). Às vezes, as vozes internas se contradizem, como no caso de Odisseu, quando pensa em matar imediatamente o ciclope com a espada, mas outra voz o impede de fazê-1o ${ }^{\text {cix }}$.

A sensação de ouvir uma voz interna que chama, intervindo nos acontecimentos ou na maneira como esses são recebidos ocorre também a Bernardo. É sempre uma voz que o protagonista não reconhece exatamente como de alguém de fora; é uma voz interna que ele conclui ser desse ou daquele ser. Um exemplo constata-se por ocasião da travessia do rio Tapacurá. Todas as palavras de força que ele atribui à mãe imobilizada na beira do rio vêm de dentro dele. A voz que ele ouve está em seu interior - a voz que o chama antes dos tiros finais: 
"De algum lugar - do campo, do passado - ou era o morto no corpo? - alguém chamava-o. Não era o seu nome, talvez nem fosse uma voz, mas ele sabia que o chamavam e que o apelo socorria-o, era uma claridade, era uma corda, um braço. (...) E a voz continuava insistente, semelhante à que rasga os pesadelos, rompe o jugo do sonho, desamarra" (OFP, 307).

\section{A opinião dos outros}

Bakhtin constatou que, assim como ocorre entre os seres humanos, os personagens de Dostoiévski se preocupam intensamente com o que os outros pensam a seu respeito ${ }^{\mathrm{cx}}$. Como o homem do subsolo de Dostoiévski - e apontado por Bakthin, pensando exaustivamente no que os outros poderiam estar pensando sobre ele, e mesmo, antecipando tais pensamentos (BAKHTIN:1998, p. 52), a preocupação com a opinião dos outros em Bernardo, é relevante. Desde o início da história, o desesperado pai quase não suporta a dor da morte do filho, pois ela traz consigo a insegurança entre o que as exigências a si mesmo impostas [em termos de respeito aos princípios morais] e a opinião dos outros. E essa opinião, veiculada nos discursos expressos ou subentendidos aparece implícita em seu autojulgamento: “Todos têm juízo, todos acham que eu pedi demissão porque quis e que ninguém tem nada com o que eu faço. Ninguém diz o que pensa, mas eu sinto" (OFP, 4).

Esse aspecto - a preocupação com o modo como o outro o vê - se percebe na fala de cunho adversativo empregada no monólogo interno, depois de ver Marvano, um capanga de Nestor, cuja figura o faz lembrar-se da morte: "Reviu a silhueta (...) como se recordasse uma alma do outro mundo (...) 'Mas eu não sou um covarde' - pensou com amargor" (OFP, 113).

Após a morte de Miguel e, por Nestor, destituído do cargo de confiança que o ex-patrão lhe atribuíra, Bernardo imagina quais seriam os prováveis juízos dos moradores do Surrão, demonstrando inquietar-se com os mesmos:

“(...) Bernardo consumia-se. A lembrança de haver acolhido a lisonja de homens que, no íntimo, talvez o odiassem, e de haver retribuído a tantos sorrisos infiéis, repugnava-o (...) Agora, com o novo dono, viam-no abandonar tarefas no Surrão. 'São novas ordens!' Sabia que assim eles pensavam e que, se contasse a todos a verdade, fingiriam crer e o desprezariam com mais um pouco de raiva. Não podiam entender que alguém renunciasse o gosto de mandar" (OFP, 124-5). 
Após a morte do bezerrinho, Bernardo pensa em sua reputação entre os moradores do Surrão e dessas conjecturas, outras noções são geradas:

"Por que obstinar-se, teimar em fazer frente a um adversário mais forte, cuja inimizade se fazia numerosa, propagava-se como uma doença? É certo que talvez nem o odiassem verdadeiramente, e sim a um mito de que ele seria a encarnação: o ódio comum, feito de ressentimentos dispersos e cego à verdadeira natureza de seus atos, adensando-se contra o mito, contra a sua alma factícia, mais real para os moradores do Surrão que a sua alma autêntica, e que os diálogos e os silêncios deles elaboravam a seu modo, tornando-o cada vez mais execrável" (OFP, 206).

Nesse episódio, Bernardo não aceita os possíveis julgamentos como verdade: "Fosse como fosse, condenavam-no sem culpa, hostilizavam-no", e percebe a sensação de impotência voltando: "Nada podia fazer, era inútil lutar", para, em seguida, refletir sobre a inutilidade de um ato de revanche: "E no fim, que resultaria a vingança? O gado ainda mugia saudoso, mas o bezerro estava morto e sepulto, não havia imprecações nem violência que o fizessem lamber de nova as mãos de Teresa". Por fim, um laivo de esperança passa por sua mente: "E talvez fosse aquele o último insulto, podia ser que se compadecessem, ou cansassem ou tivessem medo e daquele dia em diante o poupassem" (OFP, 206).

Outro exemplo de um monólogo interno que é um diálogo, em que o protagonista pensa no que outros estão pensando dele, temos na reflexão de Bernardo, colocando-se esse no lugar de Antônio Chá: "Ele imagina, pensou, que continuo ainda o mesmo, que conservo intacto o ânimo daqueles tempos" (OFP, 114).

Outra voz acre, nitidamente acusadora, é ouvida por Bernardo em muitas ocasiões, a maioria, subentendida pelo texto: a voz hostil da sogra. À filha, Suzana critica o orgulho do genro: "é tão cheio de brios, seu marido" (OFP, 35) e, embora ao expressar essa frase, especificamente, tenha-o feito em ausência de Bernardo, perante o genro muita censura é levada a cabo. Tal se comprova com o lamento do genro, tão compreensivo que enxerga algo de positivo nas ferinas palavras, comparadas aos outros tipos de discurso das pessoas de Vitória: "Só sua mãe diz com franqueza o que pensa". No dia da morte de Miguel, Bernardo opta por permanecer na cidade, a fim de aguardar o horário do enterro. Observe-se o breve comentário sobre a sogra: "Tinha de resignarse a tolerar, durante algumas horas, a presença de Suzana, seu olhar sardônico, as vingativas perguntas que não deixaria de fazer" (OFP, 97). Nesse caso, o esposo de 
Teresa já está antecipando as prováveis indagações de Suzana, os gestos corporais que as acompanhariam e sua possível reação ante tudo isso.

Ao final da história, tendo enviado a mulher para a cidade, Bernardo imagina a receptividade da mãe para com a filha e se pergunta, evidentemente, e já antecipando as costumeiras críticas: “Que diria Suzana?” (OFP, 269)

Desse modo, percebemos o discurso de Bernardo impregnado do discurso do outro, denotando a preocupação com a palavra do outro, condição que comprova a similaridade entre essa personagem e os protagonistas de Dostoiévski, cuja característica Bakhtin aponta $^{\text {cxi }}$.

Contudo, nem todas as palavras têm um objetivo trágico. Algumas exercem função oposta, mas, assim mesmo são questionadas. É o que ocorre com a voz de Antônio Chá, a qual, primeiramente se manifesta na forma pensamentos do exempregado de Bernardo:

\begin{abstract}
“(...). Sobre uma coisa ele não tinha dúvidas: nada no mundo poderia moer por inteiro o seu amigo. Famoso homem, nunca visto igual, de suma lealdade e retas decisões. Modelo de grandezas. E se interessava pelos outros, perguntara pelos seus empregos, pela bondade ou maldade dos patrões, quisera saber se ele tomara mulher. Casar de que jeito, respondera, com que bens? Para passar fome, um já bastava. Bernardo entendera, assentira" (OFP, 22).
\end{abstract}

Em segundo plano, essa voz inaudível ao protagonista torna-se um eco das enunciações anteriores, o que comprovam as reflexões de Bernardo, ao anexá-las às de Miguel: "Compreensível que um ninguém como Chá o admirasse, fizesse dele umas imensidões" (OFP, 30). O discurso relembrado se remete às falas verbalizadas (ou implícitas nas atitudes) de Antônio enquanto ambos viajaram comercializando ouro, animais e novamente expressas por ocasião da visita logo após a morte do menino de Bernardo: “- Meu padrinho, eu até hoje só quis bem a um homem. Vossemecê e mais ninguém" (OFP, 24). Ou:

"Vou-lhe dizer sem pejo, meu padrinho. Aquelas viagens que a gente fez juntos, só foi quando eu tive felicidade na vida. Até hoje, foi todo o meu comprazimento. Por onde assisti nesses anos, venerei seu nome. Meu chefe e padrinho Vieira Cedro ficou mais conhecido que tudo" (OFP, 24).

Bernardo mentalmente reputa como suspeitos os juízos de Antônio Chá porque considera o rapaz um homem pobre, sozinho e ignorante, não cabendo aqui, 
evidentemente, nenhum sentido pejorativo à conclusão. Se bem que provinda de um ninguém, essa voz, contudo, é relevante à narrativa e mesmo ao protagonista, pois o apóia, ratifica-lhe as intenções e os princípios, fazendo as vezes de espelho.

Depois desses exemplos, só podemos concluir que, mesmo que essas vozes possam também compor um diálogo "composicionalmente expresso", elas participam de um diálogo maior do que o interposto pelas palavras enunciadas, cada personagem dos acima arrolados apresentando a Bernardo sua cosmovisão e, mesmo inconscientemente, contribuindo para sua auto-elucidação. Por outro lado, percebemos que não somente as palavras dos outros entram em diálogo com o protagonista, mas "tudo provoca o herói", como Bakhtin percebeu em Dostoiévski. E nesse tudo, insere-se outros elementos da narrativa, tais como o espaço - natural ou social. As "pedras faiscantes" que trazem os sonhos de Marinheiro e a concepção do valor da vida; os cajueiros, que provocam as possíveis enunciações de Lucinda; o bamburral, a vaca, o bezerro, lembrando a promessa de prosperidade feita por Miguel; o burro, carregando os sentimentos do ex-patrão; os "ventos de agosto", a noite sem luar, tudo contribui para o diálogo de Bernardo, confirmando o que o crítico russo bem salientou sobre a obra dostoievskiana $^{\text {cxii }}$.

Tal condição corrobora as conclusões de Bakhtin no estudo sobre Dostoiévski (BAKHTIN: 1998, 48), de que constatamos não exatamente quem é, de fato, a personagem, mas a maneira como ela se autoconscientiza. A personagem não reflete a voz do autor, única e exclusivamente, já vimos que a essa voz, se mesclam as da própria personagem, que, por sua vez, re-elabora o discurso da sociedade e dos outros personagens. Ao mesmo tempo, ouve as vozes da História (de Aquiles e todos os que falam sobre sua ira) Na sua reflexão comparecem as vozes de Aquiles, dos conselheiros (doma a ira!), de Enéias (a ira final acrescida de todos os medos anteriores), e até da própria epopéia - no sentido de gênero, configurando-se uma expressão multívoca - o discurso inserido no discurso, ou como nas palavras de Bakhtin, a "interação dialógica dos discursos" (BAKHTIN: 1998, 272). Segundo o que Bakhtin percebe em Dostoiévski, os protagonistas não reduplicam meramente o discurso do autor, mas entram em discussão com os demais personagens, ficando a voz do autor como mais uma entre as vozes. E só podemos concluir de tudo isso: o romance $O$ fiel e a pedra é todo polifônico - das epígrafes aos pensamentos, as falas das personagens; do título aos nomes dessas personagens ${ }^{\text {cxiii }}$. 


\section{PARTE III - DESTINO}

Embora saibamos que os gregos da época homérica não detinham o conceito de livre arbítrio, a noção de destino interposta na Ilíada é preponderantemente a de que os deuses manipulariam, a bel-prazer, os rumos da vida humana sem pouca ou nenhuma autoridade das pessoas sobre seu futuro. Até mesmo as grandes virtudes dos heróis (valentia, inteligência, por exemplo) podem ser apresentadas como estado momentâneo insuflado pelos deuses no peito dos heróis, o menos (ardor, paixão, possessão temporária) $)^{\text {cxiv }}$ ou advir de potência divina anônima, designada daemon, que instila nos heróis idéias brilhantes, lembrança de fatos importantes ou dedução de avisos do céu ${ }^{c x v}$. Outro tipo de daemon entrar na questão, representando a moira individual, determinando o destino de forma integral ou parcial. Assim ocorre com Agamenon ao justificar o ato de usurpar a cativa Briseida como sendo uma inspiração divina: a ate cxvi $^{\text {a }}$ (uma espécie de tentação divina ou louca paixão). O rei também atribui a culpa de seu ato às Erínias e a Zeus ${ }^{\text {cxvii }}$. Ao final da narrativa o próprio Aquiles justificará a intervenção divina nos atos de Agamenon. Já se manifesta a noção de que os deuses identificados ou não - interferem nas ações humanas promovendo alteração de comportamento $^{\text {cxviii }}$.

$\mathrm{Na}$ Odisséia ainda se apresenta a idéia dos deuses regendo os destinos ${ }^{\text {cxix }}$, Ulisses/ Odisseu há de demorar dez anos para voltar a sua Ítaca e viverá dezenas de males por haver ofendido ao deus Poseidon ao ferir o ciclope Polifemo.

Eneida, por sua vez, seguirá linha parecida à de Ilíada: os deuses seriam os responsáveis pelos atos humanos ${ }^{\mathrm{cxx}}$.

Nessas epopéias, portanto, a reação do herói é, via de regra, de plena e inquestionável aceitação de tais crenças. O herói é submisso cumpridor dos ditames 
divinos. A proverbial paciência dos heróis diante do sofrimento decorria, portanto, dessa visão de mundo. Até o arrebatado Aquiles, de certo modo, expressou atitude humilde diante dos desígnios divinos, embora reclamasse de seu fado junto à mãe e também se curvasse, apesar de irado, ante a ordem real de entregar a cativa. Essa atitude de submissão aos projetos divinos é o germe da conclusão de Aquiles ao final da história de Ilíada: Zeus, com efeito, seria o responsável pela ação nefasta do rei. Também será o cerne das palavras de consolo proferidas a Príamo, quando da visita do ancião para reaver o corpo de Heitor. Aquiles advogará a tese de que não há proveito nas lágrimas, o melhor é sofrer em silêncio os males que os deuses enviam ${ }^{\text {cxxi }}$. Em relação aos sofrimentos e situações probantes, porém, nenhum herói supera Odisseu, que, por dez anos vivenciou as mais estranhas dificuldades nos mares bravios, até conseguir retornar a casa. Devido a tal reação (ou ausência dela), Homero atribui-lhe epítetos nessa linha: paciente, muito paciente, revestido de tal coração paciente, sofredor de trabalhos, sofrido, varão mais sofrido ${ }^{\text {cxxii }}$.

Osman Lins, em O fiel e a pedra, começa por emprestar de Ilíada, Odisséia e Eneida essa noção do destino como algo imutável, pré-definido. Como um Odisseu perseguido pelos revezes enviados por Poseidon, a vida de Bernardo é marcada pelo sofrimento, num rosário de ingentes mágoas: falecimento da mãe, emprego que não o satisfaz, o filho que morre sem tratamento, o patrão assassinado, o desgaste em tentar se colocar contra o erro, o bezerrinho morto cruelmente, os tiros de emboscada, o assédio moral de Nestor, a cobrança indevida e, ao final, os momentos de angústia ante o acerto final com o patrão. Essa idéia reaparecerá nas palavras de Suzana, a sogra do protagonista. Ao tomar conhecimento da inusitada proposta de trabalho oferecida ao genro por Miguel, a mulher irrita-se sobremaneira, pois a aceitação do cargo (já concretizada) implicaria na mudança de Bernardo para o Surrão e no conseqüente 
afastamento da única filha. Suzana suspira uma frase de revolta contra o destino, a quem atribui o andamento das coisas: "Agro e magro destino" (OFP, 33). Outros exemplos dessa visão aparecem sutilmente. O casal prepara a mudança, enviando os móveis antecipadamente e encaminhando-se depois, para o novo local de moradia e trabalho. Para economizar valores de passagens, aceitam carona no caminhão de Hutá Vilarim e o motorista também confirma a tese do destino como mandante incontestável, lembrando que todos têm sua "sina" (OFP, 40), ao contar do suposto caso da esposa da Miguel Benício. Mais adiante, por ocasião da estranha morte de Miguel Benício, uma personagem de nome Bindinho, o bom amigo que socorrera Bernardo com empréstimo de dinheiro, comentando sobre o falecimento do patrão de Bernardo, tenta convencer o mesmo de que nada poderia ser alterado nos acontecimentos de nossa existência: devemos nos conformar com os dias bons e maus que se alternam: “- A vida é assim mesmo, Bernardo. Dia mau, dia bom, é conformar-se." (OFP, 97). E qual é a atitude de Bernardo diante do sofrimento? Em alguns momentos, ele se mostra imbuído de docilidade ante os fatos da vida, como por exemplo, no diálogo que mantém com a esposa ao lado do berço do moribundo José: "Nem tudo pode ser como a gente quer" (OFP, 3). Nessa ocasião, Teresa retrucará que nada estava sendo como eles queriam e Bernardo lembrará sua desdita como sendo algo pré-estipulado: “- Eu sei. Tudo meu é assim" (OFP, 3). Constatando o imenso sofrimento da mulher, diz: "Teresa, eu não queria que você sofresse" (OFP, 5). Mais adiante, ao empregado, Antônio, desabafará: "Não sei quando é que vou passar o tremedal" (OFP, 23). Em outra ocasião, Bernardo voltará à mesma tese e, ainda para a mulher, analisará o desamparo de suas iniciativas: “- Nada cresce em minhas mãos. Eu sou trabalhador, você vê como eu trabalho, mas que bens você obteve esse anos todos?” (OFP, 190). Nesse mesmo evento, Teresa tentará o consolo, lembrando que, apesar de Bernardo ter sido infeliz, a condição 
certamente iria mudar. Todavia, no quesito paciência em relação aos sofrimentos da vida, Bernardo afasta-se do confiante Odisseu $^{\text {cxxiii }}$ e, no cômputo geral, aproxima-se bastante do Enéias ${ }^{\text {cxxiv }}$ virgiliano, sempre a lamentar os percalços que lhe sobrevêm e constantemente a esperar uma ajuda do Alto a fim de se salvar dos conflitos. Ele mais se aproxima de Enéias, tão caracterizado pelos queixumes, e assim permanecerá até quase ao fim da narrativa, quando suspirará: "Triste vida" (OFP, 272), pensando em sua provável morte, ou se perguntando: "E que voz, que mão amiga podia vir, descer, livrálo da morte?" (OFP, 253).

\section{Premonição}

Nessa linha do Destino como o regedor dos rumos humanos, enxergamos as tantas referências à morte ou a um fim trágico como algo a que não se pode fugir. $\mathrm{E}$ essas ocorrem através dos pressentimentos, presságios, augúrios e mesmo tendo a personificação da Morte entrevista em uma personagem. Particularmente, Odisseu e Enéias $^{\mathrm{cxxv}}$, bem como outras personagens das epopéias que narram suas ações heróicas são dados a pressentimentos e enxergam como augúrios certos fatos inusitados que quebram a rotina dos acontecimentos.

Como vimos, em certos casos na Ilíada e Odisséia, o daemon ${ }^{\text {cxxvi }}$ capacitava os heróis a perceber certos acontecimentos como avisos divinos, como Helena, enxergando no vôo de uma águia com sua presa, o augúrio de que Odisseu retornaria ao lar e executaria os seus inimigos: "Ora me ouvi, que eu, também, predizer-vos desejo, tal como / na alma os eternos mo dizem (...)" (Od, XV, 172-3). Nesse caso, a esposa de Menelau previra algo favorável ao herói Odisseu. Penélope atribui a um espirro de Telêmaco o estatuto de sinal de que o Destino acabaria, por fim, com as festanças dos 
pretendentes. Na Eneida, uma luz sobre a cabeça de Ascânio, indicará a Anquises a certeza de que família deveria abandonar Tróia.

Nesse aspecto uma frase de Aquiles soa como inusitada exceção. Ele diz: "Não me atenho a presságios" (Il, XVI, v. 50). No entanto, a enunciação afigura-se um tanto duvidosa, já que o herói se mostra muito próximo de deuses, cujo metier, sabemos, envolvia faustosas manifestações sobrenaturais muitas delas, em enigmas e símbolos.

A crença em avisos, presságios, profecias e outros correlatos, faziam parte da vida dos gregos antigos, de Homero a sucessores, como enfatiza Dodds: "Os gregos acreditavam no seu oráculo, não porque fossem tolos supersticiosos, mas porque não podiam viver sem acreditar" (DODDS, 2002, p. 81). O mesmo estudioso ainda comenta:

"Sem Delfos a sociedade grega mal teria conseguido suportar as tensões às quais estava sujeita a era arcaica. A esmagadora atmosfera de ignorância e de insegurança humanas, o horror do phthonos [ciúme, inveja, cf. p. 37,42] divino e do miasma [mancha, mácula]- o peso acumulado de tudo isso teria sido insuportável sem a segurança que um conselheiro divino onisciente podia oferecer, segurança de que por detrás do caos aparente havia conhecimento e finalidade" (DODDS: 2002, 81)

Em O fiel e a pedra encontramos farta messe de premonição que aparece sob diversas roupagens: nas muitas vozes que se cruzam, verbalizadas ou pensadas (pressentimentos na forma de pensamentos trágicos, mórbidos, advindos da sensação de potentes avisos de tragédia; pensamentos na forma de símbolos, como reflexão oriunda da visão de partes do corpo que remetem à morte ou fatos trágicos; vozes internas que chamam, gritam, intervindo nos eventos); nos sonhos (cujo cerne são, evidentemente, os símbolos); em antecipações narrativas; nos exórdios de alguns capítulos.

Bernardo, Teresa e Ascânio se entregarão a vários pressentimentos; contudo, ater-nos-emos a pressentimentos relacionados a Bernardo ou sentidos por ele cxxvii $^{\text {. }}$ 
Assim, em relação ao primeiro, o narrador diz: "No fim do mês, a presença de Ascânio - que (...) viera passar no Engenho os últimos dias das férias, dissipara em parte os maus pressentimentos de Bernardo" (OFP, 77). E Bernardo procura ocultar tais sensações, conforme se vê em um dos pensamentos de Teresa: "Ele sempre lhe escondia os maus sinais, as negras previsões" (OFP, 73).

Ao ser apresentado formalmente a Nestor Benício, o esposo de Teresa parece ter certeza do destino já traçado:

"Bernardo estava há mais de um mês no Engenho, quando foi apresentado a Nestor no armazém. Numerosas vezes encontrara-o, mas nunca lhe falara, jamais o observara de perto e a impressão que teve foi das mais intensas. Como justificar a certeza de que aquele homem, mais do que Miguel, estava ligado à sua vida e de maneira funesta?" (OFP, 56-7).

Nessa mesma ocasião, trocando duas ou três palavras com o irmão de Miguel Bernardo volta a ter pressentimentos nada alvissareiros: "Durante a breve conversa, teve a impressão de que deliberava inutilmente, sobre o próprio destino, ante o olhar sardônico da morte" (OFP, 57). Ao encerrar a entrevista com Miguel e ainda observando os gestos e expressões fisionômicas de Miguel - o olhar ávido - como o de um "morto de sede" para o imenso aneurisma do irmão, o "sorriso fino, dissimulado" que alterava a face, tornava o nariz "aceso" (OFP, 58) - Bernardo pensa: "Qual será o fim de tudo isto? E eu estou num caminho de onde não posso voltar. De onde não posso voltar" (OFP, 58). E o narrador explicita a sensação de destino:

"Aquela premonição, a aguda certeza de um mal a preparar-se, ensurdecia-o. (...). Era uma inexplicável, uma assustadora impressão. Estava no caminho de um flagelo invisível, todos os acontecimentos de sua vida não haviam existido senão para aquele momento que se aproximava e do qual Nestor Benício era o sombrio emissário. E todos os motivos que invocasse, para a si mesmo explicar seu temor, não passariam de enganos, sombras de uma verdade impenetrável, mais forte do que ele e do que tudo, verdade à qual - ele o sabia - era inútil fugir" (OFP, 59). 
Um desses pressentimentos de Bernardo aparece em excerto carregado de poesia e por esse motivo, merece nossa especial atenção. Trata-se do seguinte trecho:

“(...). Um carneiro balia. Ele olhou em redor. O sol ardia no céu nu, de um azul polido, que parecia derramar-se nas colinas mais distantes; soprava agora uma brisa muito leve e um partido de cana bem ao longe movia-se, mudava de verdes. $\mathrm{O}$ ondular das terras, aqueles vales entre os montes, além dos quais haveria outros vales e outros montes, eram como que o chamado de um mundo ilimitado, das grandes vastidões onde um homem podia ser feliz. Baixou os olhos. Aquela beleza, aquela ensolarada amplidão, doíam e atraíam ao mesmo tempo. A morte era triste, era duro morrer antes do fim, com o sangue a pulsar em toda a sua força, lavando veias novas, e a vida pela frente, cheia de acontecimentos e de estradas não vistas e também de caminhos percorridos aos quais sonhava tornar, sozinho ou tangendo uma burrama, bois, cavalos, dormindo nos descampados, sabendo que possuía um lar para voltar. Talvez morresse naquela tarde, quem sabe o que poderia acontecer? Morrer. A carne fria, os olhos murchos, o sangue derramado, as veias ocas. Talvez fosse morto - e quem, além de Teresa, haveria de chorálo? Estúpida morte, morte de um animal. Triste vida. E nem ao menos haveria uma testemunha fiel, para ver a sua morte e dizer se ele morrera como um homem" (OFP, 271-2).

Nesse ponto, vale a pena um olhar mais demorado, em nome da linguagem grandiloqüente referindo-se à força que emana da terra, à pujança da natureza, ao esplendor da vida: "O sol ardia no céu nu, de um azul polido, que parecia derramar-se nas colinas mais distantes"; "O ondular das terras"; "aqueles vales entre os montes, além dos quais haveria outros vales e outros montes". O olhar de Bernardo vai dos objetos próximos, de um "carneiro" que "balia" até aos mais distantes, feito uma câmera filmadora que enquadra os objetos próximos e, lentamente, amplia a paisagem para mais além, até o horizonte, abrangendo a vastidão do céu. Através dessas lentes se vê a natureza iluminada pela luz do sol, os tons se alternando nos verdes dos arbustos, no azul do céu; as formas se mesclando harmoniosamente - montes, vales, outros montes. Todavia, a explosão de beleza, ao mesmo tempo em que fascina, machuca: "Aquela beleza, aquela ensolarada amplidão, doíam e atraíam ao mesmo tempo". A presença da 
morte é que empana o brilho da vida: “A morte era triste (...). Talvez morresse naquela tarde, quem sabe o que poderia acontecer?” A morte é o oposto da beleza ante os olhos de Bernardo: "Morrer. A carne fria, os olhos murchos, o sangue derramado, as veias ocas". Na continuidade das reflexões do protagonista, não podemos deixar de nos lembrar de Aquiles, na ânsia de viver com fartura de dias ou no desejo de morrer na juventude, mas com o nome repleto de glória. E podemos elencar outros exemplos de pensamentos premonitórios. Mais um momento de reflexão antecipatória de Bernardo ocorre já na estrada, após a entrevista com Miguel, Bernardo rememora a conversa durante a qual o patrão informara sobre a falsa venda de parte dos bens ao irmão. $O$ narrador diz que essas considerações não abandonam o esposo de Teresa, mesmo em casa. Esse repete a conclusão: "Vai acontecer alguma coisa, coisas terríveis vão acontecer" (OFP, 76). A voz narradora também confirma a reação da mulher de Bernardo à angústia do marido: "Teresa rondava-o, sondava-o. Ele procurava esconderlhe as suas previsões".

Adiante, ao se deparar com o corpo de Miguel, supostamente caído da escada de seu empreendimento comercial, Bernardo intui que o acidente não passava de um crime: "Único a pressentir a verdade, que adivinhara desde o dia em que vira Nestor ante o irmão e à qual todos pareciam cegos. Pressentia a verdade e ninguém, senão ele, podia proclamá-la" (OFP, 95).

No caso dos símbolos (de certo modo não-verbais) como enunciadores de catástrofes, observamos alguns exemplos. Logo no início da estada no Surrão, em meio a tantos sons estranhos aos ouvidos citadinos, Bernardo sentirá que eles compõem uma espécie de agouro:

"Ergueu-se, apanhou o candeeiro, fiscalizou mais uma vez as portas, lento. Deitaram-se. Cresciam os rumores da noite, o cachorro soltou um uivo 
longo. E tudo, os uivos, a cantilena dos bichos miúdos, Nestor Benício, os homens desgarrados na escuridão, a vida naquele ermo, a pobreza que o obrigava a suportar com a mulher essas coisas, tudo pareceu fundir-se elementos de uma conspiração que o destruiria, que já o ameaçava, que fechava sobre ambos um vago, funesto, imponderável círculo. Nítido, um arrepio veio dos seus rins, subiu ao longo das costas e espalhou-se num ombro. E veio então a certeza, uma previsão clara e tão firme, que ele se sentiu sufocar: 'Nestor Benício vai assassinar o irmão'. Era inevitável: quando, sem despender um níquel, se visse na posse de todos aqueles bens e Nestor saberia apossar-se de outros mais - acharia um jeito de acabar com Miguel" (OFP, 74-5).

Nesse caso, notemos os uivos de cães ao longe, um som reiterativo, sempre remetendo ao coelho de Lucinda. Observemos também que a personagem diz que a "pobreza o obrigava a suportar com a mulher" a situação aflitiva, mas ele escolhera aquele destino desde que se opusera a Agripa Coutinho, o fiscal. Outro aspecto curioso é a inserção do termo "funesto" para o círculo que se fecha sobre o casal, também antecipador de tragédia; que, no entanto, não o destruiria. Por último, os leitores são instados a se perguntar: a "previsão clara e firme" que acomete Bernardo estará mesmo tão clara e firme? Nestor teria, efetivamente, assassinado o irmão? O romance não dirimirá a dúvida, enxertando desconfiança quanto ao resto das previsões...

Outro exemplo de símbolo augúrio ocorre quando Bernardo observa a mulher a bordar o enxoval do filho:

"Contemplou novamente a mulher. Que lembravam aqueles pés cruzados, que impressão dolorosa acordavam, tão quietos e humildes? (...) Aqueles pés... O sangue e o calor como que fugiram do peito, deixaram-no álgido e vazio, uma esponja seca: a mulher a quem sangraram o marido em Glória do Goitá fora encontrada assim, estripada, as mãos e os pés juntos, atados numa embira" (OFP, 214).

Mais um pressentimento em forma de símbolo - esse, um misto de linguagem verbal e não-verbal - ocorre quando, em Vitória, Bernardo se depara com um homem de aparência rota e doentia, olhos azuis, que o chama de Bernardinho. O homem não será identificado no romance, mas Bernardo pensará que bem poderia ser algum conhecido 
de infância ou o companheiro de juventude, Marinheiro, embora não se lembrasse ao certo se o amigo tinha o costume de chamá-lo pelo diminutivo. Enfim, o homem contará da intervenção cirúrgica para extração de um tumor alojado no pulmão. E dirá do desejo acalentado: despedir-se de Bernardo. Pegando o barraqueiro totalmente desprevenido, o homem o abraçará e o beijará levemente no ombro, proferindo em seguida um pedido: “Se eu não voltar... Um Padre-Nosso... E muito obrigado, Bernardinho, você é sempre o mesmo. Só um Padre-Nosso" (OFP, 223). O inusitado gesto há de provocar no esposo de Teresa constrangimento e perturbação, pois intuirá nele uma representação sobrenatural. As palavras do outro seguirão no mesmo sentido: assumindo a proporção de um mistério. Enfim, gesto e palavras pareciam apontar para um indício terrível: "Padre-Nosso, tumor. Talvez fosse mentira, um embuste a mais. E aquele gesto, aquele beijo? Seria mentira, o beijo no ombro? Sensação aborrecida, era como ser marcado, assinalado pelo que ia morrer" (OFP, 223).

Um pressentimento ligado a Bernardo, mas vivido por Teresa e também envolvendo símbolos, advém depois de ouvir do marido a notícia dos tiros na estrada. Teresa contempla o esposo a balançar-se na rede e remete essa visão à outra, relacionada com a morte:

\footnotetext{
“(...) os que eram mortos no campo iam assim. Estranhos levavamnos, passo firme, os punhos da rede amarrados num caibro, o caibro nos seus ombros: entravam na cidade, arriavam a carga no cimento escuro da cadeia, diziam frases brutais sobre o peso do morto, voltavam, esqueciam. As moscas farejavam o sangue, voavam em enxames grossos sobre a rede" (OFP, 251).
}

Ainda empregando símbolos - dessa vez do mundo natural - Teresa novamente tem pressentimentos indecifráveis sobre o futuro do esposo, ao ser levada por Bernardo para a casa da mãe, em Vitória, pouco antes do balanço: 
"Grandes nuvens estáticas, até então invisíveis, revelavam-se agora, pardacentas, à luz do amanhecer: e aquelas mais densas, agrupadas na barra do nascente, pulsaram, banhou-as um rubor (...).

(...) Bernardo segurava as rédeas sem falar, parecia alheio ao despontar do sol. Teresa contemplou as duas massas de nuvens que pairavam como asas sobrenaturais à esquerda e à direita dos seus ombros, uma lembrando as crinas prateadas de um cavalo, a outra semelhante a uma trombeta, ou à pá recurva de um moinho, absurda escadaria de cirros, com suas lajes imensas, unidas no espaço eterno. (...). Tudo falava uma linguagem cujo sentido ela não podia alcançar - e isto a fazia tremer, pois aqueles sinais eram terríveis em sua grandeza. Como suportar, como entender?" (OFP, 260)

Como se não bastassem esses casos, mais um pressentimento envolvendo símbolos temos nas reflexões de Bernardo em relação a um capanga de Nestor. Marvano absorve o estatuto do Mal. Vejamos como se dá tal cinzelamento. A primeira vez em que o esposo de Teresa avista essa personagem é quando o irmão de Miguel, acompanhado de outros capangas moradores do Surrão, aparece na fazenda, para buscar o gado pertencente aos herdeiros do finado Miguel: “(...). Neste momento, a uma distância que não permitia distinguir-lhe um só traço do rosto, divisou Bernardo um tipo baixo e forte: discreto, prudente e talvez com uma espécie de orgulho, contemplava-os imóvel sob o chapéu largo" (OFP, 110).

Nessa ocasião, Bernardo se opõe contra a entrega do gado dos herdeiros e Nestor espicaça a raiva dos homens que o acompanham ao dizer-lhes que não receberiam o pagamento pela falida empreitada. O barraqueiro, em contrapartida, oferece aos jagunços anistia das dívidas no barracão, o que em nada beneficiaria o único deles, uma espécie de forasteiro e, portanto, não-usuário (nem devedor) do armazém. Usando um tom que o narrador classifica "ousado, vagaroso", dando a impressão de ser "cheio de soberba", Marvano diz, em tom de ameaça, que receberia de "qualquer maneira" (OFP, 110) pelo serviço contratado. Não nos é informada a razão para a maneira como Bernardo recebe o comentário, mas esse demonstra se sentir desafiado em sua coragem 
ao ouvir o que o outro dissera. O narrador diz que Bernardo anseia enfrentar o estranho em nova oportunidade:

“(...). O desconhecido moveu-se e passou por Bernardo sem olhá-lo, maciço, num caminhar arrogante e duro. Bernardo abafou o desejo de avançar. Talvez aquele tipo, com seu enorme chapéu, seu andar insolente e de quem ele não pudera ver o rosto, nunca mais voltasse. Mas tal idéia exacerbou a sua ira e ele viu que desejava outro encontro, como quem pensa em apagar um erro" (OFP, 112).

Não saberemos que "erro" era esse que Bernardo desejava "apagar", ou se a frase representa apenas uma figura comparativa, mas a visão do homem, efetivamente, agita algo dentro do protagonista, mesmo depois que a comitiva se vai. Bernardo se recorda das palavras do outro: “(...) Ao mesmo tempo, álgida, cortante, e parecendo-lhe agora mais sombria, veio à sua lembrança a única frase do desconhecido" (OFP, 113). A Teresa, Bernardo comenta o caso, fazendo uma pergunta sobre as reais intenções do capanga. Observemos o diálogo em que isso acontece:

“- Havia entre os cabras um sujeito que eu nunca vi, Teresa. Disse que o dinheiro dele...

- Eu ouvi.

- Fiz que não escutava, mas isso me deixou com a mosca na orelha. Que é que ele queria dizer?" (OFP, 113).

Nada nos é dito sobre a resposta de Teresa; quanto a Marvano, notemos a insistência de Bernardo, os pensamentos expressos pelo narrador, procurando levar o leitor a inferir dessa personagem um caráter misterioso:

"Reviu a silhueta baixa, impenetrável sob o largo chapéu e não pôde evitar um arrepio, como se recordasse uma alma do outro mundo. Devia terse aproximado. Por que não o fizera, não desvendara aquele rosto? Sem dúvida, reconheceria o tipo em qualquer lugar que o visse. Mas recordá-lo assim, próximo, concreto e, ao mesmo tempo, sem feições humanas, parecia revesti-lo dum caráter sobrenatural. 'Mas eu não sou covarde'- pensou com amargor. E novamente ansiou por circunstâncias que pusessem à prova sua 
coragem. Ou era, essa coragem, perguntou aflito, coisa do passado, comida pelos anos?" (OFP, 113).

E assim, o narrador, dando voz à personagem, vai compondo um Marvano de aparência física e psicológica ligadas ao Mal:

"Que fazia temível aquele rosto pardo? Lembrava certas árvores velhíssimas. Um rosto de madeira, modelado a foice - e grande, desmedido, rijamente plantado sobre o tronco informe. Olhava para Antônio com firmeza, com uma determinação fanática, como se respondesse a um insulto, uma ofensa imperdoável à sua pessoa - e a brutal insolência dos olhos parecia estender-se pelas narinas infladas, pela boca cerrada, pela mandíbula pesada e intumescida, pelo pescoço de boi” (OFP, 292).

Impossível não ligar a figura de Marvano à da Morte, como a vemos nas ilustrações dos artistas, com a expressão "rosto de madeira, modelado a foice" usada para descrever o semblante do capanga. Mais adiante Bernardo pensará: “(...). O peito de Marvano arfava e ocorreu a Bernardo que uma bala naquele rosto mal talhado seria como um tiro num lajedo" (OFP, 299). É tão grande o pavor que Marvano inspira que Bernardo chega ao ponto de não mais temer Nestor, mas sim, o "desconhecido":

"O medo crescia, apoderava-se de sua alma como a sombra do pátio e ele não sabia o que fazer para estancá-lo. Sabia apenas que não vinha de Nestor, mas do desconhecido que mesmo de costas o atingia no mais profundo do seu ser (...)" (OFP, 292).

E como se explicaria temor de magnitude tal? Porque, para Bernardo, Marvano era o próprio emissário da Morte, enviado para ceifar sua vida:

“(...) como se trouxesse em si ou em redor de si o sinal claro, embora não visível, de que era o portador da sua morte, o senhor do seu destino, um ser inviolável, entidade sobrenatural contra quem nada era possível fazer e que apenas aguardava o exato instante de agir, de cumprir o seu papel sombrio" (OFP, 292). 
O narrador parece jogar uma pergunta no ar (dentre tantas): a morte pode ser enfrentada? Em dado momento do nervoso acerto de contas, Antônio diz algo que incomoda Nestor e o capanga sai em defesa de seu chefe, desafiando o empregado de Bernardo a repetir o feito. O narrador diz que a voz do jagunço era: “(...) rascante, quase fina" (OFP, 294) dotada de "uma frieza, uma indiferença, uma ausência que assustava". Observemos que o vocábulo rascante é usado para os vinhos adstringentes, que deixam travo na garganta, embora o verbo rascar seja empregado na forma transitiva, com sentido de gritar, dentre outros, e na intransitiva, significando - também, dentre outras idéias, lascar, ferir. Portanto, é possível imaginar o tipo de voz que emana de Marvano. Agradável, certamente, não era. O narrador diz que Bernardo se imobiliza e inquire mansamente: “- Que é que você faz?" - ao que o outro responde: “- Meto bala” e Bernardo desafia: “- Meta” (OFP, 294). É-nos dito que a momentânea segurança de Bernardo provoca no capanga uma reação surpresa e a conclusão do esposo de Teresa é de que o outro poderia ser enfrentado: "Pela primeira vez, Bernardo sentiu que aquele homem não era invulnerável" (OFP, 294). O balanço segue seu curso e Ubaldo ressurge em cena, evidentemente surpreendendo Bernardo que passa a imaginar qual seria o real o motivo da presença do homem. Também a ele, o narrador atribui mistério: "O homem surgira sem rumor, como um enfeitiçado" (OFP, 296). O narrador dá a entender que nessa noite, Ubaldo chega só, sem o grupo que o acompanhara por ocasião da visita noturna ao barracão. Bernardo nota profunda alteração no comportamento de Marvano após a chegada de Ubaldo:

"E, coisa estranha, se a força de Marvano era mais ampla na sombra, ele parecia agora mais cortante em sua fragilidade impassível, como um punhal cujo brilho, sob uma luz clara, parece revesti-lo de uma segunda agudeza, mais penetrante e firma que a do aço" (OFP, 296). 
Efetivamente, todos se sentem um tanto incomodados com a presença de

Ubaldo. Veja-se como o narrador o coloca:

“(...). Em torno de Ubaldo, sempre imóvel em sua atitude de longínqua indiferença, havia um movimento de estranheza - e todos o observavam, até Cizilião, embora ninguém o encarasse. Só Marvano, a cinco ou seis passos mais longe, permanecia meio de costas para ele, inescrutável, como que forçando uma réplica ao alheamento do outro e talvez incomodado pelo mistério que se irradiava da sua figura silente" (OFP, 297).

Essa personagem integrante, Ubaldo, como Marvano, é descrito subjetivamente e de forma um tanto simbólica, como se nota nas expressões narrativas: "franzino perfil de pássaro" (OFP, 296), "olhos miúdos". No entanto, esse perfil psicológico segue em direção ao Bem. Ao olhar firmemente para Bernardo, os olhos mostram similaridade com uma ave confiante: "qualquer coisa, não propriamente de pássaro, mas de ave sem susto, confiante e forte, de galo de rinha". Bernardo entende esse olhar como um gesto cúmplice: "como se ele houvesse apreendido tudo: a alma e o oculto passado, força e debilidade, intenções - e fosse inútil prolongar o exame." (OFP, 297). A intenção de aproximar a cena do sobrenatural e especialmente do trágico das epopéias, se nota na maneira como o autor descreve a cena seguinte:

"Cresciam as sombras. O claro chão do alpendre e o chão do pátio, verdes remotos, tudo se fechava, tendia para um negror de portas velhas. $\mathrm{Na}$ paisagem como que nublada, naquela mútua infiltração de cores, terra e folhagem entretecendo-se, começando a fundir-se no tom pesado e baço do anoitecer, os homens quase imóveis destacavam-se, revestidos de um esplendor que os fazia mais sinistros, a luz em torno deles lembrando esse fulgor mortal com que, em certos dias de chuva, um sol oculto endurece as saliências das nuvens. Vinham as sombras, marcavam as pregas das roupas, cavidades, rugas: e ombros, zigomas, dorsos de mãos, tudo fulgia com um brilho frio de arranhões de chumbo" (OFP, 298).

Vejam-se as expressões contundentes impregnando o texto de força poética: a paisagem é "nublada"; terra e folhagem "fundem-se no tom pesado e baço do 
anoitecer"; homens praticamente imobilizados com um "esplendor" que os fazia mais "sinistros"; a luz que os envolvia tinha um "fulgor mortal" que lembravam "dias de chuva", em que o sol que se entremostra, "endurece" as nuvens; sombras marcando os pontos do corpo que se salientam contra o céu; homens e paisagem revestidos de um "brilho frio" de "arranhões de chumbo". Bernardo vê o grupo de capangas de Nestor como embaixadores da morte:

"O grupo de inimigos pareceu-lhe inexpressivo: eles não matavam, não tinham esse poder, eram criados da Morte, única entidade temível em tudo aquilo. Mas sentiriam todos a aproximação funesta, ou seria ele o único a adivinhá-la, a saber que vinha dentro em breve? A morte algumas vezes precisava de algozes, ele tinha certeza de que Marvano seria o seu algoz, lia isto na cara modelada a foice. E por que continuava agindo como um cego, se via a Morte na estrada, caminhando severa, rumo ao barracão?" (OFP, 303)

O narrador também parece ancorar a imagem de Ubaldo na de anjo protetor de Bernardo: "De repente, no rosto frágil de Ubaldo, emaranhado nas suas rugas, Bernardo julgou entrever um sorriso de conforto" (OFP, 299). Daí para a frente, o centro nervoso do conflito mudará de Nestor e Bernardo, para Marvano e Ubaldo: "Marvano caminhava no alpendre, experimentava girar em torno do outro, que apenas se movia, não encarando o mulato, não lhe dando as costas, sempre de chapéu na mão" (OFP, 298). Ou: "Uma espécie de cansaço, torpor ou indiferença amolecia os homens. Só Marvano e Ubaldo pareciam alerta" (OFP, 301). Em dado momento e por entre a fumaça de seu cigarro, Ubaldo parecerá transmitir um sinal a Bernardo: "aconselhara-o a resistir" (OFP, 391). Mas o enfrentamento de Marvano e Ubaldo, uma espécie de desafio entre ambos, é enfatizado: "Marvano e Ubaldo estavam frente a frente. O mulato parecia interrogar, o outro se mantinha alheio e frio. No alpendre, eram os únicos imóveis" (OFP, 302). No entanto, ao perceber a retirada de Ubaldo do ambiente de conflito, Bernardo conclui estar o homem ao lado de Nestor. Sua saída, 
possivelmente, tinha um objetivo: postar-se em um lugar qualquer, talvez no caminho em que ele passaria, e alvejá-lo com uma arma: “(...) em seu espírito a morte se fez carne. Como pudera ser tão cego? A morte: um perfil de pássaro, aguardando-o na estrada [Bernardo pensa que Ubaldo estará de tocaia]" (OFP, 304). E surge a impressão de que não poderia escapar ao fim terrível que o aguardava: "Descia os degraus da morte" (OFP, 308).

A aproximação dos pressupostos judaico-cristãos em que se salienta a dicotomia Bem-Mal ou Mal-Bem, sendo ambos os vértices opostos entre si, assume vultosa proporção ao final do romance, em que, nitidamente o narrador, cedendo voz a Bernardo, enquadra um dos capangas de Nestor como o emissário do Mal, e Ubaldo, o estranho chefe do bando que visitara o armazém numa noite, o correlato do Bem. Vejamos como se dá essa composição, primeiramente refletindo sobre o caráter de Ubaldo: Observemos que o grupo de homens liderados por Ubaldo detém a capacidade - estranhíssima -, dado a inabilidade de homens rudes caminharem levemente - de não emitir qualquer som: "Não ouviu passos, nenhuma voz. Mas sabia que rondavam a casa" (OFP, 181). Bernardo imagina ser Marvano o representante do Mal, mas a comprovação de que Ubaldo se liga ao Bem, aparece num cruzamento de imagens: Bernardo imagina que o inaudível cerco só podia advir de Marvano, o capanga que deveria viver em algum lugar só conhecido pelo "diabo": "Imaginou aquele vulto sem rosto, que Nestor Benício descobrira só o diabo podia saber onde e que trouxera para amedrontá-lo" (OFP, 181). Como em muitos outros momentos, ocorre a dúvida quanto ao caráter sobrenatural do acontecimento, aspecto insinuado pouco antes: “(...) começou a perceber um murmúrio. Não sabia se a desmedida atenção impedira-o de escutá-lo antes”. Todavia a justificativa parece ser débil, pois a acentuada atenção numa noite silenciosa atilaria consistentemente os ouvidos de alguém temeroso. E não podemos 
olvidar que esse alguém ouvira o inaudível antes de se fazer audível: “(...) começou a perceber um murmúrio, não sabendo se a desmedida atenção impedira-o de escutá-lo antes. Murmúrio, rumor de passos. Foi penetrando naquela zona de sons, desvendando-a e dela se apossando, até distinguir breves palavras" (OFP, 181). Os homens bateram à porta e à janela, insistentemente: “ (...) e a janela rangeu nas guardas de madeira, sob a pressão daqueles punhos (...) começaram a bater numa das portas" (OFP, 182). Bernardo é incomodado, quase obrigado a abrir a porta e atender ao grupo: o ato de abrir a porta torna-se "indispensável", embora "simples" (OFP, 184). O caráter de premonição evidencia-se na frase: “Ansiava por ver que espécie de homens, passado aquele primeiro instante de surpresa, cruzaria os portais" (OFP, 183). A visita é "de paz", como alguém informa, ou seja, o objetivo da visita é, aparentemente, a necessidade de adquirir gêneros alimentícios, mas Bernardo desconhece tal intenção e desconfia, em frase ousada: “- É de paz querer botar a porta abaixo? (...)” (OFP, 183). Ao se abrir a porta, o narrador diz que Ubaldo parecia ser dotado de talentos sobrenaturais - sentidos superiores aos de um homem comum, como a "faculdade de sentir, no escuro, os movimentos alheios (...)" (OFP, 184). Acima da desconfiança na situação, Bernardo admira a inusitada coragem de Ubaldo: "Bernardo estava certo de não poder confiar nas boas intenções dele [julgamento errado]; mas também admirava a sua coragem, embora o mantivesse na pontaria, não pensava em apertar o gatilho" (OFP, 183). O esposo de Teresa também estranha a serena autoridade que o visitante inspira aos companheiros:

"O grupo todo parecia ter entrado. Seriam dez ou doze e, no primeiro instante, Bernardo só isolou o chefe, que ele via agora ser franzino, mirrado, o que tornava ainda mais surpreendente a rispidez, se não a autoridade que havia em sua voz. Os outros, fortes, moços, mal vestidos e todos olhando para a mulher, eram ainda um grupo indistinto, alguns de faca à mostra, outros de foice [lavradores?] e nenhum de arma de fogo, como que a formarem para o chefe um coro rústico [música], a que a imobilidade e as 
sombras grossas da parede davam um caráter de unção [bênção] e um relevo mais profundo" (OFP, 185).

Note-se, em seguida, a descrição dos homens que acompanham Ubaldo (OFP, 184): "fortes", "moços", pobres, o que entendemos na expressão "mal vestidos". A relação com os lavradores se faz pelos objetos que portam: "alguns de faca à mostra, outros de foice", utensílios que os homens do campo carregam com intenção de uso comum, não necessariamente imbricado à violência, o que se comprova nas palavras seguintes do mesmo narrador: "e nenhum com arma de fogo". Nesse passo, o narrador indica dúvida quanto ao número dos componentes do grupo: "dez ou doze”, mais adiante os chamará de "apóstolos", o que, sem sombra de dúvida nos faz lembrar Cristo e seus doze apóstolos. A alusão de cunho religioso é ratificada com expressões seguintes: os homens formam um "coro" com Ubaldo, recordando igrejas ou anjos; e as sombras de cada participante desse coro "davam um caráter de unção", termo último que, indubitavelmente nos remete ao sagrado, já que sua maior acepção é de bênção. A ligação com uma pintura barroca se faz com a referência das "sombras grossas na parede" que davam "um relevo mais profundo". Quase podemos ver um quadro de Caravaggio ou El Greco em que comporiam os personagens o homem franzino, de “nariz recurvo" parecendo "adelgaçar-se”, “olhos negros, pequenos, rutilantes”, as mãos descarnadas, entre doze jovens - o jogo de luz e sombras acentuando a pobreza de suas vestes e a simplicidade de suas faces. Ubaldo quer comprar, Bernardo acha que não era hora de vender. Ubaldo diz que a fome surge em qualquer momento e, uma vez que a porta fora aberta, o segundo passo era vender os gêneros alimentícios. Essa argumentação irretorquível deixa Bernardo "perplexo". Ubaldo, o homem que enxerga nas trevas [ou tal habilidade apenas parece existir?] vem para pôr à prova a fidelidade de Bernardo. A balança era fiel ou não? Um peso fora esquecido, talvez por Antônio, 
em um dos pratos da balança e poderia alterar a pesagem real da mercadoria adquirida. Ubaldo retirou o peso e a balança oscila até o fiel ao prumo de perfeito equilíbrio. Os olhos de Ubaldo encaram Bernardo, uns olhos "suspeitosos" (OFP, 185). É o bastante para Bernardo sentir-se ultrajado - alguém estava a duvidar de sua integridade, o que, para ele, era uma grave ofensa, já que prezava a inteireza de seu caráter. Nesse ponto da visita, Ubaldo demonstra autoridade extrema e, mediante a atitude irada de Bernardo faz um comentário perturbador: "Vosmecê está com valentia demais pr'um homem só" (OFP, 185). Todavia, essa frase se revela quase uma admoestação profética. Bernardo precisava admitir que ele carecia da ajuda externa para subjugar seus demônios: "Todos já se encontravam no alpendre, menos o chefe, cujo perfil se recortava, ousado e frágil, contra a porta aberta. Voltou-se para o casal, pesou-os, moveu a cabeça como que aprovando um juízo" (OFP, 187). Esse juízo é emitido por um gesto e o "juiz” se apresenta novamente como num quadro barroco: Ubaldo é antevisto de forma bastante representativa "cujo perfil se recortava, ousado e frágil, contra a porta aberta" (OFP, 187). Quando Bernardo se recordar da estranha visita, não mais terá dúvidas quanto ao número de homens seguidores de Ubaldo e os classificará de forma bastante representativa: serão os doze "apóstolos", palavra efetivamente empregada pelo narrador. Bernardo pensará para onde se dirigiriam aqueles homens e quais as efetivas razões pelas quais ele teria aberto a porta:

"Pensou na visita noturna, nos homens a quem abrira a porta pela madrugada. Para onde se punham? Quem seriam? O chefe era corajoso, avançara no escuro sem saber com quem tratava, arriscava-se a morrer. Mas havia uma porção de homens com ele, era fácil ter coragem com uma dúzia de apóstolos por trás. Eu não tinha ajuda e abri a porta. Mas por quê, para quê?” (OFP, 210) 
A justificativa para o ato de Ubaldo - de dar sua vida por alguém praticamente desconhecido - virá no capítulo à moda de remate, em que o narrador menciona o quinto filho de Bernardo e Teresa, de nome Ubaldo, explicando:

“(...) homenagem do pai àquele homem vindo não se sabe de onde, sobre o qual jamais houve quem desse informação exata e que levava pelo mundo, sem que ninguém se apercebesse disto, um largo coração, generoso a ponto de fazê-lo arriscar-se e morrer por um estranho - ou talvez pela justiça, ou pela coragem, ou por outro valor em que ele, confusamente decerto, acreditava" (OFP, 313).

Sabemos que as coisas não se passarão assim. Nestor será atingido fatalmente por um tiro, Bernardo ficará gravemente ferido e Ubaldo e Marvano matar-se-ão um ao outro. No capítulo de remate, somos informados que o nome do quinto filho de Bernardo e Teresa será Ubaldo. O narrador aproveitará o gancho para fazer certas considerações explicativas para o estranhíssimo ato de Ubaldo - de haver participado gratuitamente da briga entre Nestor e Bernardo, pondo-se do lado do último e arriscando (e entregando) sua própria vida em defesa do mesmo.

Em virtude da clara ligação de Ubaldo com o Bem, expressa no penúltimo capítulo, não podemos deixar de ligar algumas figuras usadas nas duas ocasiões em que se abordou a estranha personagem: porta, balança, foice ${ }^{\text {cxxviii }}$. Também não podemos deixar de entender no perfil de Ubaldo uma alusão a Cristo: o homem franzino entre doze jovens apóstolos que, muito embora sejam fortes, são pobres e simples. A "silhueta fina" (OFP, 183); a "mão descarnada"; os "olhos negros, pequenos, rutilantes"; o "nariz recurvo"; “perfil ousado e frágil” (OFP, 187); os “olhos miúdos” de “ave confiante" lembrariam Cristo? Afinal, ambos subjugaram o próprio eu em favor de uma causa. Não nos esqueçamos de que o exórdio desse capítulo é: "Visitantes noturnos. Singular figura de chefe. Revelação sem palavras. O fiel" (OFP, 181). As últimas palavras desse capítulo são: "O fiel oscilou e ficou na vertical” (OFP, 188). 
Assim, Marvano, o "emissário" da Morte, e Ubaldo, o emissário da Vida (pois a concede a Bernardo) vão batalhar entre si, o que justificam a parte do verso: - 'E ouviuse um estrépito e clamor imenso.' (HOMERO, Ilíada, rapsódia XLI.)" [OFP, 283] ${ }^{\mathrm{cxxix}}$.

Sonhos

Ilíada, Odisséia fornecem exemplos de sonhos como avisos sobrenaturais, conselhos advindos do além ou mensagens de repreensão dos deuses ou fantasmas. Aquiles sonha com Pátroclo, que lhe cobra os funerais; Agamenon sonha com um clone de Nestor, que o aconselha, na guerra; Penélope sonha com a sombra de sua irmã, que a consola da angústia; depois, sonha com uma águia devorando gansos (um aviso de que Odisseu retornaria) ${ }^{\mathrm{cxxx}}$. Como bem poderia acontecer com qualquer pessoa, todos se impressionam bastante com tais ocorrências. E isso não soa estranho aos nossos olhos, pois, dependendo do sonho, sentimo-nos inquietos, temos a sensação de adentrar para outro mundo. Dodds, comentando acerca do assunto, afirma: "O ser humano divide com alguns poucos mamíferos o privilégio de possuir cidadania em dois mundos distintos. Ele goza, em diária alternância, de dois tipos de experiência (...) cada qual com sua lógica e limitações próprias. (DODDS:2002, p. 107). Esse mesmo estudioso lembra que Heráclito foi quem primeiramente discorreu sobre o sonho: "o primeiro homem que explicitamente pôs o sonho em seu lugar foi Heráclito, com a observação de que durante

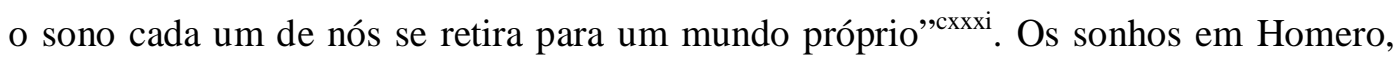
portanto, estão ligados ao mito e são tratados como objetivos, embora Penélope fale ao mendigo/Odisseu de dois tipos de sonhos - os banais, que saem das "portas de marfim"; e os que detém profecia, vindos das "portas de chifre" (Od, XIX, 560-1). Dodds comenta o fato: 
"Na maior parte de suas descrições de sonhos, os poetas homéricos tratam o que é visto como se fosse 'fato objetivo'. O sonho normalmente é apresentado como uma visita feita por uma figura onírica a um homem ou mulher adormecido - a própria palavra oneiros em Homero quase sempre significa figura onírica e não experiência onírica. Esta figura onírica pode ser um deus, um fantasma, um mensageiro de sonhos preexistente, ou ainda uma imagem (eidolon) criada especialmente para a ocasião. Porém, o que quer que seja, ela existe de maneira objetiva no espaço, independentemente do sonhador. Ela encontra passagem pelo buraco da fechadura (...); se coloca à cabeceira da cama para transmitir sua mensagem e se afasta pelo mesmo caminho" (DODDS: 2002, 109-10)

E como se manifestam esses sonhos? Os sonhos são caracterizados por uma atitude passiva do sonhador, mesmo que ele tente alcançar o objeto onírico (o que apresenta-se como mero ato físico). Reportando-se às epopéias de Homero, Dodds explica:

“(...) o sonhador permanece quase completamente passivo: ele vê uma figura, ouve uma voz e ponto final. É bem verdade que às vezes ele responde em sonho, e que uma vez ele estica os braços para abraçar a figura em questão. Mas esses atos são físicos. O sonhador não crê estar em outro lugar, a não ser em sua própria cama; e na verdade sabe que está adormecido, pois a figura onírica se esforça para lhe indicar isso: 'você está adormecido, Aquiles', diz o fantasma de Pátroclo; 'você está adormecida, Penélope', diz a imagem de sombras na Odisséia" (DODDS: 2002, 110) (cxxii $^{\text {con }}$

Virgílio imita Homero, inserindo sonhos objetivos em suas personagens épicas.

Na Eneida, Enéias sonha com Heitor, Mercúrio e Anquises e os sonhos seguem a mesma linha de Ilíada e Odisséia, sendo avisos de fatos futuros, advertência, mensagens de esperança e incentivo ${ }^{\text {cxxxiii }}$.

Em O fiel e a pedra, sonhos também são revestidos de alto grau simbólico e premonitório. Dentre eles, ressaltamos alguns exemplos. Após ouvir o insólito pedido de Miguel, para que matasse o suposto amante de Creusa, o espírito de Bernardo se turba. No caminho para casa, remói as palavras do patrão, angustia-se com todas as nuanças do caso e ainda se sente culpado por não conseguir vencer seus escrúpulos e auxiliar um amigo. Por outro lado, se sente ofendido com a proposta. Essa 
multiplicidade de sentimentos continua no Surrão e se manifesta em angústia diurna e pesadelos durante a noite. Os sonhos são reiterativos:

"Nas três noites que a isto se seguiram, repetidos pesadelos lhe cortaram o sono. Miguel Benício, visto ou pressentido, participava sempre deles. E não obstante as ameaças, apesar da confissão - que tinha uma firmeza de sentença -, ele era sempre a vítima, sempre o que fugia ou sucumbia nas ameaçadoras visões" (OFP, 91).

Nesse ponto da narrativa confirma-se o caráter antecipador da narração. O leitor é informado da morte de Miguel, evento a ser narrado no capítulo seguinte: "E isto não estava longe da verdade, pois havia de ser ele - e não o seu comborço - que amanheceria morto" (OFP, 91). Outro sonho recidivo acontece depois do incidente no rio Tapacurá - o cruzamento, quase fatal, ocorrido na adolescência: "Durante uma semana, ele tivera pesadelos. A travessia do rio repetia-se, com os pormenores de sempre e só o grau de angústia se alterava" (OFP, 63). O sonho voltara a acontecer esporadicamente: "duas ou três vezes na vida, desde que homem feito" (OFP, 60) - e antes de fatos desagradáveis: "sempre antecipando uma desgraça", por exemplo, seis meses antes da morte da mãe. Pois esse angustiante sonho volta logo depois de Bernardo conhecer Nestor Benício.

Outro sonho que impressiona grandemente Bernardo ocorre antes do balanço final - meio dormindo, meio acordado, ele imagina sentir uma presença no ambiente. Deduz ser a mãe. E intui que ela lhe transmite uma mensagem: de que não matasse Nestor, como ele, nos momentos de desespero, intentava fazer. O capítulo XLII, que narra esse evento, é antecedido pelo exórdio: "Nuvem protetora. 'E Vênus, a branca deusa, entre celestes nuvens, era presente e trazia o dom.' (VIRGÍLIO, Eneida, VIII.) A reconquista" (OFP, 237). Assim, uma obviedade se manifesta: Osman Lins, aqui, deixa um tanto de lado os poemas de Homero e se volta para a epopéia virgiliana. 
Virgílio, sabemos, era adepto do epicurismo, e o sonho (visão/impressão) de Bernardo parece muito próximo do epicurismo de Virgílio (tão francamente exposto em Geórgicas e Eneida). Vejamos como se dá essa aparente modelagem. Efetivamente, não há como ignorar a aproximação que Osman Lins faz de seu protagonista ao Enéias virgiliano - sim, porque na Ilíada, Enéias é muito mais aguerrido e impetuoso ${ }^{\text {cxxxiv }}$. Então, laborando nessa linha de pensamento, a sensação de receber a visita da mãe morta, não se liga à crença da imortalidade da alma, mas sim, à cosmogonia grecolatina, particularmente na relação Enéias-Vênus, forte herança de Ilíada ${ }^{\mathrm{cxxxv}}$. Segundo o epicurismo, os deuses são calmos (ao contrário do que criam os gregos com as brigas monumentais entre um deus e outros) e se comunicam em espírito com os seres humanos. Eles vêm aos homens quando esses estão tranqüilos, relaxados, desligados do mundo real ${ }^{\mathrm{cxxxvi}}$, preferencialmente, dormindo. Tal idéia parece casar-se perfeitamente com as palavras introdutoras do capítulo: "Deitados lado a lado, como dois mortos. Ambos estirados, imóveis, de mãos dadas, os pés da mulher abrigados no lençol, os de Bernardo descobertos. Calados" (OFP, 237). Em seguida, o narrador falará da noite, dos sons naturais noturnos, gado mugindo; galos cantando; rãs em seu coaxar; vôo de morcegos; e os fará silenciar-se pouco a pouco. A voz narrativa contará que Bernardo, insone e preocupado com a emboscada do inimigo, levantara-se; depois, voltara a se deitar, aos poucos adormecendo, muito embora não se sentisse relaxado de todo: "Ele sabia onde estava, sabia que era noite alta e lembrava-se, com uma intensidade crua, de estar sozinho em face da maldade" (OFP, 239). É nesse estado de semitorpor que tem a impressão de sentir umas mãos cruzadas dentro das suas:

"Havia alguém na sala, alguém o visitava, uma visita de misericórdia, com as mãos tão fortemente cruzadas que esta força parecia expandir-se, comunicar-se às mãos dele. E não sentira aquelas mãos insinuarem-se entre as suas, nem o deslizar da pele, nem a pressão que elas deviam ter feito" (OFP, 239). 
Notemos as palavras: "visita de misericórdia" remetendo às divindades que se compadecem dos mortais. E a comprovação de que o texto não se liga a aparição de mortos, mas à divindade, segundo o epicurismo de Virgílio, vem com as palavras a seguir: "Transpusera uma linha interdita, estava numa região virgem. Mas era preciso aguardar, não precipitar a revelação que a muda presença anunciava, esperar como um morto, como um ausente, para que tudo não cessasse e para sempre" (OFP, 239). Vejase a expressão: "esperar como um morto", que leva à conclusão de que ele, Bernardo, deveria estar totalmente inerte - como morto - para receber a revelação - exatamente a maneira como Epicuro preconizava serem as revelações dos deuses. O texto fala em uma "linha interdita", ou seja, proibida aos mortais. Que linha seria essa a não ser a que existe entre a divindade e o ser humano? A comunicação aí não se faz entre homem e homem, mas sim entre uma deusa e um homem. Essa "região virgem" (e proibida) seria o Éter, como o chama Virgílio? Sim, porque o Hades não era interdito aos mortais, já que Odisseu e o próprio Enéias vão até esse lugar. Na verdade, o epicurismo não aceitava a imortalidade da alma. Embora Virgílio tenha inserido o diálogo de mortos com Enéias, numa alusão literária a Odisseu, a crença do poeta seguia em outra direção. Como a epígrafe que inicia o capítulo aborda a vinda de Vênus trazendo as armas divinas a Enéias, é evidente que a aproximação vai nesse sentido: a mãe de Bernardo é alçada de sua condição humana e elevada a um patamar divino. E essa divindade nada fala. Suas prováveis palavras são intuídas, numa repetição do que ocorrera no rio Tapacurá, em que o menino imagina que a mãe, inerte na beira do rio, lhe diz para ter força:

"Continuou imóvel, as mãos sob o queixo, unidas, como as de quem pede. Sim, como quem roga. Mas eram as outras, aquelas mãos de mulher 
(...), eram elas que estavam tensas de súplica. Que desejavam então, que socorro buscavam, se ele é que sofria, que estava perseguido, sem lei e sem amigos? Indagou, indagava e ao mesmo tempo desatava-se nele um amor claro, que o transpunha de sua condição para outra, uma condição mais lúcida, onde a linguagem reinava no silêncio, as palavras dos lábios sendo inúteis. Não fizesse aquilo, não matasse Nestor, não manchasse de sangue as suas mãos. Confiasse e não temesse, ela haveria de guardá-lo. E também não se fosse, não fugisse. Ficasse. Revestido de fé, entregue à sua proteção, ficasse. Ela o amparava, ela o envolvia, ela o resguardava contra os cães.

E silenciou, como que intimidada. Parecia recolher-se, ocultar no silêncio a face que uma palavra fizera entrever" (OFP, 239).

Observemos a reação de Bernardo: ele vai de um estado de espírito em comoção - o amor atado - para uma "condição mais lúcida", ou seja, do emocional para o racional, mais uma vez, se aproximando de Epicuro, que defende a ciência como solução para a angústia humana.

A aproximação com o divino comprova-se também com a palavra fé, tão ligada à religiosidade. Fé é a crença no que não se vê, no que não é empírico. Bernardo deveria ser revestido de fé - uma prova de que estava faltoso dessa condição - e assim, seria resguardado pela mãe. E protegido contra os cães - novamente a alusão à Bíblia, ao coelho de Lucinda e aos inimigos de Bernardo.

Em Eneida, Vênus sente temor dos poderes do Mal - Juno e demais divindades a serviço das ações nefastas. Aqui, Lucinda silencia como que "intimidada" (OFP, 239). Como Enéias grita pela mãe, almejando tocá-la, abraçá-la, Bernardo faz algo parecido:

“(...). Vai me deixar - pensou Bernardo. Vai desaparecer e nunca poderei estar certo se realmente foi ela, se estas mãos e este conforto que eu julgava para sempre ausentes... Isto era triste. Mas talvez, talvez... De leve, devagar, livrou uma das mãos, tocou aqueles dedos, afagou as veias do pulso, a curva interna do braço, o cotovelo, a manga arregaçada do vestido. Era ela, sim, não tinha mais dúvidas, sabia. Quis abraçá-la, gritou ou julgou gritar pelo seu nome" (OFP, 239-40). 
$\mathrm{O}$ excerto em que Bernardo tenta tocar a mãe parece remeter-se a Enéias tentando um contato físico com Vênus, sendo que esse episódio é um resgate de Odisseu também procurando um gesto afetuoso de Anticléia:

"e, desejoso de o espírito ao peito apertar com ternura, arremeti por três vezes, levando-me o peito a abraçá-la; por outras tantas dos braços fugiu-me, qual sombra fugace, ou mesmo sonho, deixando-me dor mais acerba no espírito" (Od, XI, 205-8).

A pungente imagem de Odisseu ansiando o abraço confortador da mãe será retomada por Virgílio, quando Enéias tenta achegar-se a Vênus e por Osman Lins, em $O$ fiel e a pedra no sonho de Bernardo com Lucinda, nesse sonho que não se sabe se é.

As alusões implícitas no gesto de Bernardo - na direção da suposta Lucinda têm algumas afinidades entre si. Odisseu tenta por três vezes tocar a mãe, mas não consegue:

"Mãe, por que evitas o abraço em que tanto desejo estreitar-te? Não poderíamos nós, até mesmo aqui no Hades, os braços entrelaçar e atenuar, desse modo, a tristeza indizível?" (Od, XI, 210-2).

E a mãe justifica:

"esse o destino fatal dos mortais, quando a vida se acaba, pois os tendões de prender já deixaram as carnes e os ossos.

(...)

A alma, depois de evolar-se, esvoaça qual sombra de sonho" (Od, XI, 218-9, 222).

Enéias também tenta por três vezes tocar Creusa ou o pai... e também vê sua intenção inviabilizada. Mas Bernardo toca no braço da mãe e sente as veias, algo que não existiria em um morto... As veias se remetem ao sangue... e todos sabem que esse se acaba com a morte. Aliás, sangue é um sinônimo de vida. José, ou o menino que 
aparece no sonho de Teresa tem "veias secas", sem "sangue, sem esperança" (OFP, 257). A inserção de uma Lucinda passível de ser tocada, porquanto dotada de corpo e, particularmente, de veias - e sangue/vida -, se afasta de sua co-irmã Anticléia, que não pode ser alcançada por ser apenas uma névoa. A Lucinda que não se faz presente de corpo, cuja voz não se faz audível, tem braço e veias/sangue... Seria uma Lucinda viva? A negação da condição sobrenatural advém com as palavras seguintes:

"Não estava dormindo, não naquele instante em que sentira as mãos entre as suas. E mesmo que estivesse, quem podia afirmar que a pobre velha só regressara da morte no seu sonho? Não havia sonhos como aquele. Lucinda viera e encontrara-o nas trevas, e não trouxera apenas o conforto de vir. Mas palavras: uma súplica, um alento, um compromisso. Aquelas veias túmidas, o pulso forte, o braço, aquele vestido grosso - como não crer?

(...)

“(...) Ela estava ali, envolvia-o e não podia ser tocada. Nunca, não mais" (OFP, 240).

O mesmo se dá com Enéias. No caso de Anticléia, ela justifica que os mortos não têm matéria. Vênus, por sua vez, abraçará o filho ao lhe dar os dons (as armas). Lucinda é tocada, as veias são possíveis de ser notadas. Portanto, Lucinda está viva, o sangue não deixara de seguir pelas veias túmidas. Bernardo toca uma mãe viva, porque o faz mentalmente.

Teresa também contará a Bernardo sobre um pesadelo que a abalara. Ela sonhara com o filho morto, o pequeno José, mas não fora um sonho bom, pois o menino lhe aparecera de forma monstruosa e assustadora, assumindo a aparência de um demônio a gritar impropérios, chamando alguém de assassino e emitindo uma espécie de frase profética: seu pai iria morrer (OFP, 254-60). Durante todo o dia, a mulher de Bernardo se recordará com incômodos sentimentos o sonho da noite passada: "aqueles olhos acesos, impuros, cheios de rancor, aquele rosto envelhecido de criança" (OFP, 255). O narrador diz que Teresa não reconhecera o filho amado naquele ser aterrorizador: “(...) e 
uma suspeita enregelara-a: 'Ele não é meu filho. É o demônio'”. Acerca desse sonho, lembremo-nos de que é relatado no capítulo XLV, cujo exórdio é: “ 'Bem depressa alcançaram a corrente do Oceano e a Pedra Branca, enfiaram pelas portas de Hélios, ultrapassaram o País dos Sonhos, e ei-los enfim no Prado dos Asfódelos, onde habitam as Almas, imagens dos Mortos.' (HOMERO, Odisséia, rapsódia XXIV.) - Rompe a manhã" (OFP, 254) ${ }^{\text {cxxxvii }}$. O que vemos aqui? Um passo acerca de mortos, antecedendo o sonho com um morto, ligação que se afigura óbvia entre a noção de morte para os gregos antigos e o que se nos mostra o romance osmaniano em questão.

Vozes internas

Os pressentimentos podem vir na forma de vozes internas. Um exemplo ocorre no texto a seguir, referente aos episódios finais da narrativa:

"No momento em que estendeu a mão para o chapéu, foi assaltado por uma espécie de lembrança ou de pressentimento, a consciência de uma realidade malévola e obscura. Como quem busca ouvir, mal desperto, um grito de socorro só existente em sonho, voltou-se para fora (...) ele sabia que o chamado existia - real e enérgico - embora tão fugitivo, que fora impossível apreender a sua verdadeira significação. Entrevira uma verdade sem rosto. O mais inquietante era a convicção - que não lhe vinha da mente, mas vibrava em cada músculo - de que a realidade lembrada ou pressentida não se referia a ninguém, a nenhum fato presente: aguardava-o além do lugar ou do minuto em que estava. Com o corpo inteiro ele recebia aquela realidade e era o mesmo que penetrar na escuridão.

(...) E lhe veio a certeza de que era a Morte que ele pressentia. Era ela que se aproximava, que se anunciava, rondando-o como nos livros de gravuras" (OFP, 303).

Essa voz se confundirá com outro símbolo, agora internalizado - o de um morto dentro de si: "Não mais lutar, não mais viver. Por quem, por quê? Tinha um cadáver no corpo, um morto, um morto negro e sujo" (OFP, 307).

Antecipação do narrador/ anacronia 
Em O fiel e a pedra encontramos uma voz que segue paralela à do narrador e que se anuncia nas citações preliminares (uma espécie de arauto), as epígrafes que abrem a obra, nos exórdios dos capítulos, alguns contendo excertos de textos anteriores. Tanto essa voz quanto a voz narrativa oficial antecipam os fatos que se seguirão. O primeiro exemplo de antecipação é, sem dúvida, a tríplice profecia existente nas epígrafes iniciais. Como vimos na primeira parte deste trabalho, antes mesmo de ler a primeira linha do romance saberemos que o protagonista é um "macho de coragem", que é natural de Vitória, que é nascido das pedras e que será envolvido numa guerra. O trecho camoniano lá inserido assim reza: "Antes de guerra férvida e robusta a nossa história seja... (CAMÕES, Lusíadas, Canto VI, XLI.)" (OFP, -1). Esse excerto camoniano será continuado no último capítulo do romance. A citação da Ilíada antecipa o capítulo XLIX, juntamente com outro fragmento poético emprestado a Camões. Ambos tratam de guerra. Leiamos o exórdio completo: "O homem decide o seu destino " - '... pois dureza nossa vida há de ser, segundo entendo, que o trabalho por vir m’o está dizendo.' cxxxviii(CAMÕES, Lusíadas, Canto Sexto.) - 'E ouviu-se um estrépito e clamor imenso.' (HOMERO, Ilíada, rapsódia XLI.)” (OFP, 283). A frase que abre o exórdio remete ao principal homem da narrativa, intrinsecamente relacionado à guerra, portanto. A alusão direta à Ilíada justifica-se por trazer o ambiente do poema - o cenário das batalhas entre gregos e troianos. Já relembramos o fato de que ambos os povos, auxiliados por reis vizinhos, lutavam por Helena e seus bens. A citação de Os lusíadas também se refere à guerra. Para melhor entender a alusão, consideremos o contexto dos versos apropriados. O sexto canto de Os lusíadas inicia-se abordando a confraternização entre povos, os festejos promovidos pelo "Rei Pagão", o rei de Melinde, ao "Rei Cristão”, Vasco da Gama. A esquadra lusitana parte das terras estrangeiras e segue rumo ao seu alvo, as Índias. Os objetivos da Eneida, a implantação de um império de 
paz e prosperidade conforme o desejo dos deuses, se repetem nos sonhos portugueses: "Via estar todo o Céu determinado / De fazer de Lisboa nova Roma; / Não no pode estorvar, que destinado / Está doutro poder que tudo doma" (Lus, VI, estrofe 7). Mas a monotonia da viagem, na vastidão do mar sem fim provoca torpor nos marinheiros, os quais buscam meios de se manter despertos: "Remédios contra o sono buscar querem" (Lus, VI, estrofe 39). A pronta sugestão é narrativas: "Histórias contam, casos mil referem" (Lus, VI, estrofe 39). Um navegante dá a idéia de que sejam narrados contos alegres, leves; outro, apaixonado e saudoso, opina que sejam narradas histórias de amor. Um terceiro intervém: não deveriam homens em tão rude situação, deixar-se levar por "branduras", ou seja, entregar-se aos sentimentos delicados da alma ${ }^{\text {cxxxix }}$. A "brandura" das narrativas sentimentais não combinaria com a "aspereza" das circunstâncias. Os contos de amor tornariam os homens melancólicos e tal estado de alma os levaria a esmorecer diante da realidade. Mister era insuflar no ânimo guerreiro dos homens portugueses mais coragem a ardor de luta, porque, certamente, o futuro próximo lhes reservava duros embates. Então, impõe o gênero adequado ao momento: contos de "guerra", e de "guerra férvida e robusta". O qualificativo seguinte indicará o tipo de narrativa ideal: os fatos reais das sangrentas batalhas nas quais os reis de Portugal combateram. Elas seriam usadas exemplarmente, para que os lusitanos se sentissem inspirados a imitar os feitos heróicos do passado. O poder de influência instigadora da literatura, então, fica explícito nesse passo:

"Consentem nisto todos, e encomendam

A Veloso que conte isto que aprova.

'Contarei, disse, sem que me repreendam

De contar cousa fabulosa ou nova;

E porque os que me ouvirem daqui aprendam

A fazer feitos grandes de alta prova,

Dos nascidos direi na nossa terra,

E estes sejam os doze de Inglaterra"

(Lus, VI, estrofe 42). 
E na continuidade dos versos, Veloso justificará: “... pois dureza nossa vida há de ser", relembrando aos sonolentos marujos que a realidade é dura, difícil, diferente do sonho: Que o trabalho porvir m'o está dizendo" ${ }^{\mathrm{cxl}}$. Enfim, como ao final da Eneida, o Enéias doce e amoroso precisará dar lugar ao guerreiro. $\mathrm{O}$ amor cedendo lugar para o estatuto da guerra. Bipartindo-se, os versos de Os lusíadas, - um misto de Ilíada, Odisséia e Eneida misturadas, tanto abrem quanto fecham a história de $O$ fiel e a pedra, apresentando um ambiente para o herói "valente sem pabulagem" e "nascido das pedras" cxli: a guerra inóspita e sempre árdua. Seguindo a mesma linha das demais citações, na obra integral da qual foi extraída, a vitória acontece: os lusitanos vencem as duras provas e logram êxito em sua empreitada. Na Ilíada, a guerra se faz probante, como sabemos, com muito sangue correndo e membros espedaçados. Em Os lusíadas, a condição quase perene de guerra não permite livre curso do sono restaurador. O capítulo de $O$ fiel e a pedra em que se encrava a citação de Os lusíadas, acrescida à frase de que o homem decide seu futuro, apresenta a agonia do funesto acontecimento por vir, um evento que a personagem não sabe ao certo como se dará, ou qual sua monta. O que o protagonista apreende é justamente sua grandiosidade e o quanto exigirá dele física e psicologicamente. Bernardo se mostra ansioso ante o conflito final com Nestor. Dorme alguns minutos apenas, durante a noite, mas consegue racionalizar. Fora acuado, sentiase amedrontado, mas permanece firme. Pouco a pouco vai se acalmando, a ansiedade dando lugar a uma "atitude resoluta" (OFP, 284), concluindo que, se o inimigo queria enfrentá-lo, que viesse. O empréstimo literário tem muito a ver com essa tortura psicológica de Bernardo.

Ainda comentando acerca das vozes narradoras que antecipam os fatos, depois das epígrafes iniciais, percebemos que o narrador procura enfatizar a condição de as 
personagens caminharem sob o tacão do destino. É o que se vê no caso de Antônio Chá. $\mathrm{O}$ antigo ajudante de Bernardo chega à cidade e visita o ex-patrão a fim de propor-lhe o retorno às viagens e se depara com o casal pranteando a morte recente do filho. Bernardo lhe sugere que busque apoio junto aos fazendeiros da região e Antônio o faz, sem sucesso. Vai bater, depois, na porta de Miguel Benício, pois se lembrara de que o rico homem tinha Bernardo em alta conta desde a época em que adquirira animais de sua mão. Antônio conjectura que, usando o nome de Bernardo, poderia alcançar boa acolhida. O narrador, porém, nos induz a acreditar que o pobre moço tem essa idéia, motivado por algo sobrenatural: "Não podia suspeitar que obedecia, como um cão impelido pelo faro, ao rastro que o destino pusera à sua frente e que poderia levá-lo a inimagináveis caminhos" (OFP, 26). Ou seja, Antônio Chá - comparado a personagem com um animal que se deixa levar pelo instinto, mais forte que ele - era dirigido cegamente por uma força sobrenatural, o destino, o qual tinha por supremo objeto o próprio Bernardo.

No capítulo XXXVII, o narrador apresenta o sofrimento de forma bastante intensa e simbólica. Vejamos o conteúdo dessa parte do romance: a vaca primeiramente adquirida no Surrão dá à luz um bezerro que se torna uma espécie de bichinho de estimação para Teresa. O animal se alimenta confiadamente de sua mão e observando a cena, Bernardo se queda enternecido. Numa discussão, porém, o vigia da fazenda ameaçara matar o pobre bicho, o que deixara o esposo de Teresa enfurecido. Por essa razão, Bernardo, de sua parte, também ameaçara acabar com a vida de quem tocasse o animal. Certa noite, no entanto, o bezerro aparece morto brutalmente e Xenofonte jura não ser ele o autor da maldade. Bernardo fica reticente em crer nos argumentos do homem, mas o que parece contar mais efetivamente são os sentimentos envolvidos no triste episódio. A visão do bezerro ensangüentado acrescida do som dos mugidos da 
mãe do bichinho, isso tudo somado aos olhos magoados de Teresa, provocam em Bernardo a recordação de outro incidente não menos doloroso ocorrido em sua infância: o ataque de cães selvagens a um indefeso coelhinho que sua mãe criava com especial afeto. Cães vadios haviam percebido a presença do coelho e rondavam a casa, ameaçadores. Em determinada noite, acercaram-se da gaiola do animal, mantiveram-no acuado por um tempo e depois o mataram ferozmente. Bernardo recordava-se da sensação de impotência e do ódio que o acometera na ocasião ao ver o pobre bicho estraçalhado e o mudo sofrimento da mãe. Com a morte covarde do bezerro, sentimentos idênticos voltavam-lhe ao coração:

"Como se pareciam as sensações de agora com as daquele tempo, enquanto abria a cova com sua mãe silenciosa ao lado, como se pareciam a sua revolta de menino contra os dentes dos cães e sua indignação de hoje contra a faca de um homem, sua raiva muda a um inimigo incerto, humano hoje, ontem canino, a impressão de conivência a escavar a terra, o cálido amargor na boca" (OFP p. 204).

Diante do cadáver do bezerro, Bernardo pensava: "Por que os cachorros vinham no escuro, por que não mordiam na frente?” (OFP, 202). A metáfora será empregada novamente, não no plural, mas individualizada, ao ser desafiado pelo vigia, nessa mesma ocasião. Bernardo dirá, com muita raiva interior: "Dobre a língua, cachorro!" (OFP, 203). Mais adiante, aguardando a chegada de Nestor para o acerto de contas, e observando a movimentação ameaçadora dos capangas, Bernardo observará dentre eles o mesmo vigia e se aborrecerá. Xenofonte jamais deveria apoio a Nestor, visto que fora estupidamente surrado pelo patrão. O esposo de Teresa rememorará o episódio do bezerro (que carregava em si a morte do coelho): "Cachorros desgraçados, cheios de glória e de fome, aguardando o instante de morder-me" (OFP, 288). Iniciado o balanço e pressionado por Nestor, Bernardo recordará o incidente do mascote da mãe e terá 
medo: "Recordou o coelho de Lucinda, mordido pelos cães. O medo crescia (...)" (OFP, 292).

Como entender esses pressentimentos em forma de pensamentos trágicos, símbolos, vozes, sonhos e outras manifestações ligadas aos augúrios das epopéias? Primeiramente, admitindo exatamente o que a pergunta contempla: a adoção de um elemento epopéico como recurso literário em um molde contemporâneo (o romance). Em segundo lugar, pensando na força de tal elemento na feição dos poemas advindos de tão distantes eras. $\mathrm{O}$ augúrio, os pressentimentos estavam imiscuídos ao pensamento da época, o qual incluía a cosmogonia, a maneira de entender o Universo. E tal pensamento não podia dissociar-se da religião praticada por gregos e latinos.

Dada sua feição de veiculadora e cristalizadora dos acontecimentos históricos que envolviam os povos e suas crenças, a epopéia era o meio ideal para a criação e propagação dos mitos ${ }^{\text {cxlii }}$. Por se tratar de um poema repleto de grandiosidade e simbolismo, caracterizado pela exaltação dos feitos heróicos, em tom elevado e grandiloqüente, espelhava o espírito e as virtudes de uma nação, questionando a vida, o universo, enfim, e assumindo-se como uma espécie de busca. E se os antigos olhavam os céus sentindo-se participantes da magia do universo, vislumbrando os deuses como a suprema orientação ou impedimento no caminho a seguir, compreendendo assim, a totalidade do universo mesclada ao mundo real e apreensível, e tudo sendo passível de interpretação por uma ótica sublime, veja-se o que Osman Lins diz de sua arte:

"E a narrativa para mim é uma cosmogonia. Eu penso assim: existe o mundo, existem as palavras, existe a nossa experiência do mundo e a nossa experiência das palavras. E tudo isto está ordenado, é um cosmos. Mas no momento em que o escritor se põe diante de uma página em branco para escrever o seu livro, a sua narrativa, o mundo explode, as palavras explodem, então ele está novamente diante do caos do mundo, e do caos das palavras, que ele vai reordenar. Vai haver uma nova passagem do caos ao cosmos. É nesse sentido que todo o problema do caos e do cosmos me atrai, 
é pelo fato de quando eu me ocupo das cosmogonias, vamos dizer assim, estou me ocupando da narrativa." (ET, 223-4)

O autor, como artesão de uma palavra que remonta às suas origens, trazia em si o ideal de compreender o universo através de sua literatura: “(...) eu diria que a minha inclinação, a minha atração pelo cosmos, quando manifestada literariamente, aparece com muita dificuldade. Como se fosse exigir muito de mim chegar a uma compreensão mais abrangente do mundo" (ET, 219). Todavia, a humildade em saber que embora reflita sobre tudo, muito ainda haverá por desvendar aparece na fala: “(...) porque eu próprio, como um homem, levarei sempre em mim esta contradição: a de debater-me entre a ânsia de compreender e a certeza de que tudo é mistério" (ET, 181). Assim, as inserções de pressentimentos e sonhos se mostram ao leitor de um modo dúbio, como o autor discutisse com seu público as dúvidas que habitavam a alma. Sem almejar a exaustão do assunto, vejamos algumas das possíveis leituras dos pressentimentos apresentados em $O$ fiel e a pedra. Em relação ao pressentimento de Bernardo ao ser apresentado a Nestor ${ }^{\text {cxliii }}$, sabemos que o mesmo adveio após a impactante descrição do irmão de Miguel, feita por Hutá Vilarim. A história do atropelamento do cordeirinho; a atitude agressiva direcionada aos passantes; a apimentada sugestão de infidelidade em relação ao irmão (o provável caso com Creusa); a desconfiança para com os que lhe prestavam serviço - tudo havia sido descrito em detalhes e arrematado à conclusão de que Nestor Benício não valia "nada" (OFP, 40). Assim sendo, não é de estranhar a reação de Bernardo ao ser apresentado por Miguel ao irmão. O narrador diz que o esposo de Teresa não estendera a mão - gesto social básico no momento em que se é apresentado a alguém. Observe-se o constrangedor impasse:

"Não estendeu a mão. Também Nestor não fez menção de erguer-se, não esboçou nenhum gesto: fitava-o de viés, sem levantar o rosto, um olhar duro, suspicaz, sarcástico, como se quisesse penetrar-lhe a alma. Bernardo se 
lembrava da história que Hutá Vilarim contara na viagem. 'Então, é este! É este!"” (OFP, 56-7)

Somado ao rol de gestos mesquinhos elencados por Hutá Vilarim com referência a Nestor Benício, havia o que os olhos e a mente de Bernardo estavam rapidamente apreendendo. Em relação ao irmão doente de um sério aneurisma, Nestor se portava como um "morto de sede", ávido de arrancar de Miguel tudo o que esse possuía. Bernardo intuiu que Nestor tentaria alcançar seus objetivos sem respeitar nenhum obstáculo do caminho, justificando-se, portanto, a sensação angustiante de estar no meio de uma zona de guerra, uma perigosa armadilha que o prejudicaria também, a "certeza de que aquele homem, mais do que Miguel, estava ligado à sua vida e de maneira funesta" (OFP, 56-7).

Quanto ao pressentimento de Bernardo ao contemplar a bela paisagem do Surrão ${ }^{\text {cxliv }}$ e conjecturar que talvez morresse naquela mesma tarde, sabemos que tal presságio não se concretiza no decorrer da história. Nem mesmo ao final da narrativa nos depararemos com a morte do protagonista. E sobre o pressentimento de que o patrão fora assassinado ${ }^{\text {xlv }}$, a tal "verdade" pressentida por Bernardo não se firma no desenrolar do romance. $\mathrm{O}$ assunto não mais virá à baila e o leitor não saberá ao certo se Nestor, efetivamente, matara o irmão (afinal, Miguel poderia ter simplesmente caído da escada). Da tese de assassinato restará somente a débil autodefesa de Nestor, portando-se como um réu perante um magistrado, um "severo juiz", como ele mesmo o diz, e insistindo em sua inocência: "Que ninguém fosse julgar um homem, como quem dá sentença sobre o tempo: pelas aparências" (OFP, 100). Mas, e o severo juiz, o que concluirá sobre o caso? Não saberemos. O narrador falará de outro ponto: a desconfiança de Bernardo em relação à maneira de se comunicar de Nestor: "Bernardo mal respondia. Bizarro, aquele irmão de Miguel. (...) Parecia inseguro, mas visava certeiro os seus 
propósitos" (OFP, 101). Bernardo se calará acerca do caso da morte do patrão e das suspeitas que acalentara no dia em que o corpo fora encontrado e a partir dessa conversa (ou do monólogo de Nestor), a morte de Miguel será relegada ao esquecimento. O desafio entre os dois homens é que será o centro da narrativa. Além disso, o pressentimento de Bernardo acerca da morte de Miguel terá sido, portanto, um tanto ambíguo, nunca se confirmará ou negarác ${ }^{\text {xlvi }}$. E ainda, o pressentimento que Bernardo tem numa noite, em que os sons do campo o fazem pensar em futuros acontecimentos trágicos, também tal sensação pode explicar-se por ocorrência anterior. Bernardo havia ido a Vitória e ouvido do patrão uma proposta constrangedora:

"Ia assim a vida reconstituindo-se, quando um pequeno fato, na antevéspera de Santo Antônio, veio revolver aquelas apreensões já meio esquecidas, que a presença de Nestor provocara há três meses em Bernardo. Miguel Benício quis saber: aceitava, na qualidade de amigo, comprar-lhe algumas casas, transação fingida, válida somente no papel?” (OFP, 70).

A reação de Bernardo fora de assombro: "Ele se espantara, havia perguntado o que significava essa loucura" (OFP, 70). Note-se que considerava a idéia como "loucura". Evidentemente, a sugestão deixara Bernardo bastante preocupado: Miguel estava convicto de ser traído e arquitetava planos que, certamente, o levariam a uma situação de risco. Esse desconforto ressuscitara as inquietações do dia em que conhecera Nestor, sensações que o próprio narrador informara estarem adormecidas. Essas "apreensões" se costuram aos sons que o casal citadino ainda não se acostumara a ouvir. No entanto, esse medo do novo e desconhecido se amainará e os mesmos sons tornarse-ão "normais" com o decorrer do tempo. Também não nos esqueçamos de que a “conspiração que Bernardo julgava viria a destruí-lo” (OFP, 74-5) não acontece com tal magnitude, ao final de contas, pois não será destruído. E com referência à certeza de que Nestor iria assassinar o irmão, repetimos: não saberemos se de fato concretiza-se. $O$ 
leitor poderá aderir à “certeza” de Bernardo, mas o assunto, de certa forma, será abafado no decorrer da narrativa.

Nessa mesma linha, segue-se conclusão acerca do pressentimento ao ver Teresa com os pés cruzados, o que lhe recordara a mulher cujo marido fora assassinado em Glória do Goitácxlvii, também perceberemos ser apenas um desses pensamentos negativos que se tem quando o medo toma conta, pois os pés lembrando os dos mortos, farão somente isso: rememorar uma visão negativa: "Que lembravam aqueles pés cruzados, que impressão dolorosa acordavam, tão quietos e humildes? (...) Aqueles pés...[grifo nosso]" (OFP, 214). Bernardo tem o pressentimento da morte, mas não morrerá, ao final da história.

Quanto ao pressentimento advindo do inusitado encontro com um homem na rua $^{\text {cxlviii }}$, mais uma incógnita se estabelecerá. Seria aquele estranho um amigo de adolescência? Poderia ser o irmão que partira na juventude e nunca mais retornara? $\mathrm{O}$ beijo repentino e constrangedor, pega Bernardo de surpresa e ele se sente, de certa forma, marcado. Talvez marcado para morrer. Por outro lado, o esposo de Teresa conjectura que o gesto e as palavras poderiam fazer parte de uma encenação, o que já desconstrói a tese do augúrio, sendo essa desconstrução corroborada com as palavras que assinalamos: "sensação aborrecida" e "era como ser marcado, assinalado pelo que ia morrer" (OFP, 223) - "sensação" e "como" - elementos indicadores de dubiedade que denotam a incerteza quanto às tais apreensões. Mais um pressentimento equivocado.

Também o pressentimento de Teresa, acerca dos mortos ${ }^{\text {cxlix }}$ que eram trazidos do campo, carregados em redes (a imagem será retomada por Bernardo ao permanecer sozinho no Surrão, aguardando Nestor para o acerto de contas) mostrar-se-á infundado. Bernardo sairá ferido do balanço, mas será devolvido com vida aos familiares. 
Ressalva se apresenta apenas quanto ao outro pressentimento da esposa de Bernardo, o que lhe ocorre ao ser levada para Vitória, pouco antes do balanço, é, certamente, uma forte e bela imagem. O narrador, dando voz a Teresa, considera a cena como "sinais", "terríveis em grandeza", que a mulher não entendia, nem ao menos conseguia suportar. O narrador menciona nuvens assemelhando-se a "asas sobrenaturais". Uma delas lembraria uma "trombeta" ou a "pá recurva de um moinho"; a outra, "as crinas prateadas de um cavalo" cl. Teresa não apreende os sinais e nós, os leitores, o que podemos deduzir desses símbolos? Talvez sejamos levados a conjecturar que o narrador estaria ligando Bernardo a um cavaleiro apocalíptico a se opor aos moinhos gigantes ou, quem sabe, a um cavaleiro protegido pelo "espaço eterno", uma espécie de arauto da justiça. De qualquer modo, a imagem não se esclarece e o leitor ficará livre para fazer sua leitura. Enfim, não é um pressentimento que envolva fatos negativos. Bernardo pensa que Marvano, o mais assustador dos capangas de Nestor, é o emissário da Morte, isso provou-se por tantos excertos. Todavia, não é possível desprezar a expressão "parecia revesti-lo dum caráter sobrenatural [grifo nosso]" (OFP, 113), que nos induz à alta carga de subjetividade na questão. Essa última característica, aliás, é recorrente em todo o romance, como temos visto: pouco nos é afirmado com segurança, o que comprovam as seguintes frases: “(...). Reconheceu-o e vacilou, abafando um movimento de pânico: jamais um rosto humano lhe causara tão profunda impressão [grifo nosso]" (OFP, 291).

Outro aspecto que induz o leitor a pensar é a conclusão de Bernardo a respeito da vulnerabilidade de Marvano/Morte, expressa na frase: "Pela primeira vez, Bernardo sentiu que aquele homem não era invulnerável" (OFP, 294). Enfim, o "destino" - e a morte como parte integrante do mesmo - não se mostrava tão hermético... Bernardo errara nas previsões quanto a Ubaldo também. O homem e seu bando estiveram de noite 
no armazém do Surrão e o esposo de Teresa havia desconfiado da visita: "Um homem se adiantou (...). Bernardo estava certo de não poder confiar nas boas intenções dele (...)" (OFP, 184). Ao ver o mesmo homem chegar ao Surrão, durante o balanço, Bernardo julga que ele seria o encarregado de matá-lo. O esposo de Teresa se confundirá com um gesto do homem. Por entre a fumaça do cigarro, Ubaldo parecera incentivá-lo a se manter firme, "aconselhara-o a resistir" (OFP, 391). Bernardo novamente muda de opinião ao ver Ubaldo partir: agora imagina que o estranho teria sido o verdadeiro responsável por todas as ações nefastas ocorridas no Surrão, como a destruição do cará, a morte do bezerrinho, os tiros na estrada [atos que não terão autoria definida no romance]. Veja-se como Bernardo elabora mentalmente a próxima ação do homem: "Ubaldo no caminho, à espreita. Morte do animal, estrago na plantação, falsa tocaia, tudo ele" (OFP, 305). No entanto, ao perceber a retirada de Ubaldo do ambiente de conflito, Bernardo conclui estar o homem ao lado de Nestor. Sua saída, possivelmente, teria um objetivo definido: postar-se em um lugar qualquer, talvez no caminho em que ele passaria, e alvejá-lo com uma arma: “(...) em seu espírito a morte se fez carne. Como pudera ser tão cego? A morte: um perfil de pássaro, aguardando-o na estrada" (OFP, 304). E surge a impressão de que não poderia escapar o fim terrível que o aguardava: "Descia os degraus da morte" (OFP, 308) - previsão infundada, pois, como veremos no penúltimo capítulo, Bernardo ficará em posição bastante delicada, mas não sucumbirá. A morte não terá sucesso nesse episódio, ao menos em relação ao esposo de Teresa. A única constatação que podemos efetuar, nesse caso, é de que as conclusões de Bernardo se mostram contaminadas de medo, angústia e até mesmo, esperança - enfim, alto grau de subjetividade. O protagonista recordará sua facilidade em equivocar-se nos julgamentos: "Ubaldo voltava (...). Como podia estar tão certo disto, ele que tanto se enganava?" (OFP, 307). 
Pensando no aspecto das antecipações narrativas, essa dá não apenas no nível do narrador, mas também nos empréstimos literários constantes no romance. Veja-se o caso dos textos de Camões e Homero ambientados na guerra. Apesar de remeterem aos efeitos terríveis dos conflitos humanos (corpos tombando, morte), mesmo tais citações antecipam o desfecho exitoso de $O$ fiel e a pedra. Vejamos por quê: na Ilíada, Aquiles volta com ímpeto sem igual para os embates com os inimigos; ao final, Tróia será derrubada. Em Os lusíadas, Vasco da Gama e os colegas navegantes precisam enfrentar duras provas a fim de conquistar seus objetivos, sofrem oposição de seus compatriotas, deparam-se com gigantes e figuras monstruosas no mar inóspito, batalham contra exércitos traiçoeiros, mas chegam ao destino e cumprem sua missão. Bernardo, por sua vez, tão questionado por todos em relação às conseqüências de suas atitudes éticas e à firmeza de resoluções, toma contato com a maldade e a hipocrisia de jagunços dispostos a tudo por fidelidade ao patrão sem escrúpulos, e enfrenta perigos visíveis e invisíveis. O embate que se dará entre Bernardo, auxiliado por Antônio Chá, e Nestor com seus jagunços, será comparado a uma guerra imensa em sua força destruidora, com “estrépito" de armas e corpos tombando. No entanto, Bernardo sairá vitorioso e Antônio Chá, seu companheiro de lutas, ileso.

E acerca da antecipação quanto a Antônio Chá, de que esse, ao procurar Miguel para obter emprego estava simplesmente obedecendo ao "rastro que o destino pusera à sua frente", e isso "como um cão impelido pelo faro" resta-nos comentar que o protagonista há de discutir essa condição no decorrer da narrativa. Basta lembrar seus questionamentos acerca da ingerência sobrenatural na vida humana, após sonhar com a mãe, assunto que traremos à baila mais adiante.

Mais ainda: sobre outra antecipação na forma de símbolos ocorrida no capítulo XXXVII, podemos efetuar algumas considerações. O capítulo é antecipado com uma 
epígrafe bíblica: “Porque me odeiam muitos cães raivosos, uma turba de malfeitores me cerca.' (Salmos 21,17.)" [OFP, 199] ${ }^{\text {cli }}$. E tal empréstimo, já sabemos, poderá ser rico para a compreensão do exposto nessa parte do romance. Vejamos como. O salmo 21 (em certas versões, 22) é um cântico que se inicia com o Messias, condenado em um julgamento arranjado às pressas, torturado, e, na cruz, ridicularizado. Totalmente à mercê de seus algozes, Ele clamará a Deus por livramento e Se lamentará. Observando os escarnecedores que mofam de sua fé, da doutrina que pregava, de Seus princípios de vida - incluindo a extrema confiança no Deus Pai que o enviara -, o Messias Se sentirá excluído e injustiçado e constatará a sensação de estar acuado, o que se percebe em símiles contundentes ("touros de Basã", "leão", "cães”). Depois, arrematará: "Livra a minha alma (...) da força do cão" ${ }^{\text {"clii }}$. Assim, um triste momento da vida do Messias é emprestado para introduzir o infeliz evento da morte do bezerro, que por sua vez remete a mais um acontecimento ruim - o ataque ao coelhinho de Lucinda. Em todas as situações há algo em comum: uma vítima acuada, sentindo-se impotente diante de inimigos cruéis. Ao dizer que os cães ${ }^{\text {cliii }}$ aguardavam ferozes, o momento de mordê-lo, Bernardo é desenhado na pele dos animaizinhos e, numa aproximação literária (guardadas as devidas proporções) ao Messias auto-sacrificado. Mas, apesar de anunciar a intensa agonia de físico e alma do Messias, e, nesse sentido aparentar ser um cântico elegíaco, o salmo tem uma mensagem de otimismo, a começar do título - O Messias sofre, mas triunfa. O que temos, então? Um Ser acuado, ameaçado e vilipendiado que no final de sua tortura torna-se vencedor, fato comprovado nos derradeiros versos do salmo - uma seqüência de louvores à vitória alcançada. Dessa forma, ao escolher especificamente esse poema hebraico, o autor de $O$ fiel e a pedra ${ }^{\text {cliv }}$ concede lampejos do que acontecerá ao herói também acuado e auto-sacrificante. Como no salmo, manterse firme entre os cães raivosos, confiando em um poder superior, é a única saída para 
um projeto de vida voltado a um objetivo elevado. E a atitude de se postar firme ante os “cães” é uma escolha. O destino, portanto, está nas mãos de quem realiza a opção.

Os sonhos proféticos também não se explicam nitidamente como tal, deixando ao leitor a dúvida se seriam mensagens proféticas ou apenas o resultado de grande comoção. Vejamos o caso dos primeiros sonhos referidos. Após ser acometido de pressentimentos acerca do fim de Miguel, Bernardo sonha com a morte do patrão. O que fora previsto em pensamentos repete-se nos sonhos como "ameaçadoras visões" (OFP, 91). Miguel morre, certamente, mas ambos haviam falado de morte, na visita que Bernardo fizera ao patrão, pouco antes da tragédia. O esposo de Creusa planejava assassinar o provável rival. Miguel pedira auxílio a Bernardo para executar o serviço, porém o funcionário se mostrara contra o projeto. Enfim, a mente de Bernardo estava repleta de anúncios de morte. Assim, Bernardo tanto poderia ter sonhado em razão da perturbação de espírito, quanto em função de um "aviso" sobrenatural, nesse caso, intencionalmente uma modelagem segundo as epopéias citadas.

O segundo sonho mencionado é com a travessia do rio Tapacurá. Para entendermos esse sonho, precisamos atentar para a descrição do evento. Vejamos como o narrador no-lo apresenta. A vida de Bernardo corre aparentemente bem até que é apresentado ao irmão de Miguel, Nestor Benício. Subjugado pelas tenebrosas impressões que decorrem do encontro, Bernardo sonha com um acontecimento ocorrido na pré-adolescência: certo dia em que cruzara o rio Tapacurá e quase se afogara (outro ato de ousadia da parte de Bernardo). O volume de águas estava bastante alterado em razão das chuvas de junho, mas os rapazes das cercanias tinham como esporte preferido cruzar o rio até uma pequena ilha, acenar vitoriosamente para os outros meninos que observavam a façanha, e depois de restabelecido o fôlego, retornar à margem. Completados 15 anos, Bernardo se sentia um homem feito e desejara fazer igual (uma 
espécie de rito de passagem da adolescência para a vida adulta) e como se houvesse um acordo tácito entre ele e a mãe, não solicitara permissão para o ato, mas apenas comunicara as intenções a Lucinda. Embora a mãe não atentasse completamente para a autonomia que aos poucos se amalgamava no caráter do menino, quase inconscientemente apercebia-se da questionabilidade de suas ordens, já que destinadas a um adolescente tão desejoso de instaurar-se como senhor de sua vontade (e não mais a uma criança). Lucinda não ordena, mas aconselha a que o rapazinho desista do empreendimento, justificando como razão, sua pouca idade: "Não se meta a imitar essas façanhas. Você não é grande bastante para isso" (OFP, 61). A reação ao conselho é a que se esperaria de um jovem nessa idade: com o orgulho próprio atingido, Bernardo sentira seu desejo fortalecer, o que o aproxima do conceito de vontade e autonomia que, desde o estoicismo a Kant afirmou-se como uma qualidade moral que remete à firmeza de caráter $^{\text {clv }}$. Bernardo vai além e rubrica outro pressuposto kantiano, de que a vontade se organiza tendo como base única a própria idéia de lei em geral, independente de alheias determinações de cunho afetivo, econômico ou social. O menino impõe-se contra a vontade da mãe a quem até aquele momento obedecera prontamente, dando-se ao direito de ousadias sem grandes conseqüências, comuns à maioria dos garotos de seu meio social:

"Muitas vezes, até àquela hora, Bernardo cedera a arrebatamentos. Subindo em altas árvores, nadando em açudes profundos, lutando com rapazes mais velhos e mais fortes do que ele. Aquele (...) fora o seu primeiro gesto realmente viril, o primeiro passo à frente do homem que amadurecia em silêncio dentro dele e que, afinal se afirmara, um tanto prematuramente (...)" (OFP, 62).

As palavras de Lucinda funcionaram como um disparador no desejo (“consciente e irresistível”, conforme o texto) de mostrar que já não era tão pequeno 
assim: "Ela não dissera ainda a última palavra e ele já prometia a si mesmo, desafiandoa com secreto orgulho: 'Vou atravessar'” (OFP, 61).

Bernardo se instaura como o legislador e súdito de sua vontade, o que nos lembra, mais uma vez, o filósofo alemão ${ }^{\text {clvi }}$. Apesar de amar e respeitar a mãe, sendo assim o oposto do irmão perdulário e negligente dos deveres filiais, Bernardo sente dentro de si crescer a ânsia por autonomia e vai se estabelecendo como ser independente, a quem nem mesmo a mãe pode influenciar para longe de seus princípios. Seus atos passarão a ter responsabilidade ditada pela consciência, ou seja, definidor de suas próprias leis, não se submete à vontade dos outros - já está alicerçado no rapaz o pressuposto comentado da autonomia como fundamento da dignidade humana. O projeto de cruzar o rio adveio de uma noção de que já estava apto para tanto; o passo seguinte fora a decisão para a ação efetiva; em seguida houve o anúncio desse projeto e, por fim, a execução do mesmo. A vontade autônoma prevalecera, então. Bernardo, como sujeito, se transformara no ator de sua trajetória, a vontade firme pressupondo o livre-arbítrio, remetendo à liberdade e opondo-se ao determinismo ${ }^{\text {clvii }}$. Na ocasião, o herói quase perdera a vida, pois as águas impetuosas do rio não deram trégua ao seu corpo ainda juvenil. A linguagem poética do narrador emoldura, então, a renhida luta de um ser humano contra a natureza. Escolhera o entardecer, quando todos os freqüentadores já se haviam retirado e agora eram ele e a correnteza os dois atores do dramático espetáculo. Interessante é o fato de que o capítulo que narra o sonho é antecipado por uma epígrafe extraída de Geórgicas:

"Assim, por lei do fado, piora toda coisa, e com desvio volta para trás; não de outra forma aquele que contra a corrente, com esforço de remos faz subir um barco; se por acaso afrouxou braços e brio, a impetuosa corrente leva-o arrebatado rio abaixo"clviii. 
Os versos nos brindam com a imponente imagem de um solitário barqueiro em meio a um turbilhão aquático que lhe rouba as forças e o impede prosseguir viagem. $\mathrm{O}$ barqueiro não confia apenas na potência de seus músculos e no poder de sua vontade, mas usa o equipamento que impeliria o barco à frente, os remos. Então, vontade, músculos e remos se unem na tarefa de singrar as águas, com a esperança de avançar. O remador consegue "subir", ou seja, navegar contra a correnteza, que por si só representaria a soma de influências determinantes na vida de uma pessoa. O restante das palavras está na condicional: "se por acaso afrouxou braços e brio". Assim, é uma advertência que vemos na imagem, não uma tragédia acontecida. Se o barqueiro não se empenhar, ele será levado de roldão "rio abaixo". O poeta lembra que a vitória depende de dois fatores: o físico - "braços" - e o psicológico - "brio", o orgulho. Está lançada a fórmula para o sucesso ou o fracasso de uma empreitada. O futuro aqui se condiciona à ação do remador. Caso ele prossiga em sua luta, conseguirá alcançar sua meta. Se fraquejar, ele descairá, como tudo o mais na vida. Já não existe somente a premissa do futuro predeterminado, mas sim uma possibilidade - quase um questionamento - de que se houver empenho, alcançar-se-ão os objetivos propostos. Nessa balança - usando a imagem básica do título do romance de Osman - Virgílio não estaria propondo que o destino poderia ser modificado, uma vez que, se os deuses desejassem, o remador jamais conseguiria lograr êxito contra a correnteza?

Não podemos deixar de refletir sobre a diferença entre esse remador do poema virgiliano e Odisseu, que, por mais que fizesse não conseguia alterar os rumos de sua vida, já que estava preso aos ditames da maldição de um deus furioso. Nesse caso, porém, o barqueiro pode mudar sua história. E talvez Osman Lins tenha percebido essa possibilidade, subliminar quase, pois a epígrafe serve de fundo para o capítulo em que Bernardo sonha com o episódio ocorrido no desabrochar de sua adolescência - a 
travessia quase fatal, do trecho de um rio da região em que vivia. Como o solitário barqueiro de Virgílio, Bernardo arrosta o perigo e enfrenta a morte, quase soçobrando, entretanto, ao dar-se conta do peso de seu isolamento e sentir-se incapaz de prover sozinho, sua salvação: "O terror da solidão fizera-o estremecer e ele, por um breve instante, sentira-se vencido, incapaz de mover-se, entregue às águas que pareceram adquirir de súbito uma assustadora placidez" (OFP, 62-3). Diz o poema [e diz a vida] que, caso o barqueiro se deixasse levar pelo medo, a embarcação seria levada aos borbotões, para baixo e para trás, ao ponto de partida. O menino Bernardo bem deseja que sua salvação seja operada por alguém, mas a realidade é diversa: “(...) e não havia ninguém para salvá-lo" (OFP, 61). De dentro do menino assustado, nasce o homem confiante que interfere no destino de forma eficaz. Sopesando logicamente a situação, conjectura: "Se meu corpo pode, eu posso (...). E se meu corpo não puder, ainda assim talvez eu possa" (OFP, 62). Esse homem não deixa a ausência de "brio" determinar a ação, ao contrário, usa a razão e resgata o poder da vontade para lograr êxito na dura travessia, corroborando Kant quando diz que a vontade é a razão prática ${ }^{\text {clix }}$.

Lucinda diria: "Você não será vencido (...), nem pela sua fraqueza, nem pelo seu medo" (OFP, 62). Seriam essas palavras verdadeiro mantra que a mente de Bernardo trazia à tona para motivá-lo a lutar? Somos tentados a antecipar a conclusão de que, pelo caráter do menino é que vem a prova e pelo caráter é que se salva, segundo o que avalia sua mãe, após o evento: “- O que lhe salvou foi sua firmeza, Bernardinho” (OFP, 63). O sonho com a travessia do rio Tapacurá também se reveste de simbolismo, pois volta a ocorrer antes de uma "desgraça" (OFP, 60), como a morte de Lucinda e após a apresentação de Nestor. O leitor não será informado de detalhes da morte de Lucinda, os quais seriam úteis ao entendimento da condição áugure do sonho: teria a mãe de Bernardo morrido de alguma doença que a acamara por algum tempo? Morrera Lucinda 
repentinamente? Na primeira hipótese, o sonho poderia advir da sensação de que a mãe iria falecer, já que se encontrava enferma. Na segunda, o sonho, efetivamente, seria premonitório. De qualquer modo, o sonho ocorre depois que conhece Nestor. Nesse caso, o autor pretendia dizer que tudo o que viesse posteriormente seria a "desgraça"? Parece que sim, pois esse último sonho não mais retornará, nem mesmo diante das novas situações angustiantes, como os ataques à propriedade, os tiros de emboscada ou o balanço final - desgraças consideráveis.

Sobre o terceiro sonho de Bernardo, aquele em que lhe aparece a mãe (ou ele imagina tal coisa), a negação da condição sobrenatural advém com as palavras seguintes, uma conclusão a que o próprio sonhador chega: "Não estava dormindo, não naquele instante em que sentira as mãos entre as suas. E mesmo que estivesse, quem podia afirmar que a pobre velha só regressara da morte no seu sonho? (...)"(OFP, 240). A inserção de uma Lucinda passível de ser tocada porquanto dotada de corpo e, particularmente, de veias - e sangue/vida -, se afasta de sua co-irmã Anticléia, que não pode ser alcançada por ser apenas uma névoa. A Lucinda que não se faz presente de corpo, cuja voz não se faz audível, tem braço e veias/sangue... Seria uma Lucinda viva? A negação da condição sobrenatural advém com as palavras seguintes:

"Não estava dormindo, não naquele instante em que sentira as mãos entre as suas. E mesmo que estivesse, quem podia afirmar que a pobre velha só regressara da morte no seu sonho? Não havia sonhos como aquele. Lucinda viera e encontrara-o nas trevas, e não trouxera apenas o conforto de vir. Mas palavras: uma súplica, um alento, um compromisso. Aquelas veias túmidas, o pulso forte, o braço, aquele vestido grosso - como não crer? (...) Ela estava ali, envolvia-o e não podia ser tocada. Nunca, não mais" (OFP, 240).

Observe-se a expressão "mesmo que estivesse": não haverá certeza de que Bernardo estava dormindo - portanto tivera um sonho - ou desperto. Outro fator é o toque. Afinal, mortos não têm corpo, veias túmidas e uma Lucinda de pulso forte, veias 
túmidas vestido grosso, seria uma Lucinda viva (a lembrança eterna da mãe). Bernardo foi acometido pela imagem da mãe, como ele a percebia na infância: o vestido rústico, por exemplo... A mãe viera a ele, efetivamente, na lembrança de seu estímulo mudo, da força que sempre transmitira ao filho, desde sua infância. Tais dúvidas remetem ao Enéias de Virgílio, nesse ponto, uma espécie de alter-ego do poeta. Quando Enéias encontra Vênus disfarçada de caçadora ("instruída na arte dos áugures" - alusão ao caráter premonitório da mensagem a ser veiculada e também uma alusão ao encontro de Ulisses e Nausícaa), o herói acaba identificando a mãe-deusa por sua característica maior, que é o fato de deslizar no chão sem caminhar. Enéias deseja maior contato, mas Vênus foge ratificando a constante inacessibilidade ${ }^{\mathrm{clx}}$. Após o sonho/visão ou impressão, Bernardo se sente mais confiante: "Ele não era mais um prisioneiro, já não estava cercado pelo seu temor e pela ameaça do inimigo. Só esta persistia, mas ele a desprezava: abrigava-o uma nuvem, um escudo invisível" (OFP, 241). A lembrança de Lucinda trouxera a Bernardo a paz através de um pedido - que não matasse Nestor e que permanecesse firme no Surrão, pois ela o protegeria. Esses foram os dons da Lucinda imaginada - não armas em que se liam o futuro, mas a única arma que o salvaria de fato - seu autocontrole:

"Abriu a porta. As silhuetas pesavam contra o céu baço e até as árvores, até os bambus tinham uma aparência pétrea. Paisagem negra, sólida, uma severa paisagem mineral. Mas era o mundo aberto, onde ele se sentia livre e ao qual regressava sem temor. Seguiu em direção às mangueiras e cada passo no chão úmido tinha um sabor de afirmação: ele reconquistava um reino" (OFP, 241).

Observemos que Bernardo "regressava" ao mundo natural - o mundo de "aparência pétrea", paisagem "negra, sólida, uma severa paisagem mineral”, o que nos remete ao mito de Deucalião, dos homens vindos das pedras. Essa imagem nos faz lembrar da dureza de vida dos homens pobres, sertanejos, onde leis, conforto ou 
respeito quase inexistem. Todavia, esse é o mundo de Bernardo - o mundo dos homens - e a esse ambiente ele retorna "sem temor". Dentro de Bernardo algo se transformara era agora um vitorioso [mais um momento de premonição, dentre os tantos do romance], sabia-se imune às intempéries. Afinal, com a divindade ao seu lado, ele “reconquistava um reino", o que faz Enéias, com a ajuda da deusa-mãe.

E por fim, o protagonista sentirá que a esperança renascera: uma chuva repentina e intensa caíra e já o céu se mostrava estrelado indiciando o alvorecer - uma imagem para a esperança que ressurgia. O protagonista voltará a pensar no assunto, mais adiante, sozinho no Surrão. Sentindo-se abandonado pela suposta ajuda divina, prepara-se para arquitetar uma solução - como Odisseu, diante dos problemas:

"E como ele pudera crer num sonho, acreditar que a mãe viria protegê-lo? (...) Estava só, sem a ajuda dos vivos nem dos mortos. Mas não devia errar pelos campos, ir e vir de um lado a outro do Engenho, queimar-se no sol, desperdiçar as energias quebradas até não poder mais e voltar. Alguma coisa era preciso fazer. Pensar, medir, tomar posição. Situações como a sua exigiam uma espera, uma preparação" (OFP, 269).

Esse aspecto pode afigurar-se a uma dúvida do autor quanto ao caráter da liberdade que é inerente ao homem. Estaria o ser humano condicionado a forças sobrenaturais? Nesse caso, a liberdade não seria um atributo exclusivo e individual, mas da totalidade. Portanto, está colocada uma eterna dúvida, um enigma sobre o qual os pensamentos das personagens oscilam de um lado a outro: o futuro do homem a ele pertence ou é gerido por forças sobrenaturais? Essa questão permeia toda a narrativa a par de uma reflexão ontológica que aqui se vê.

Acerca do sonho de Teresa com José, exposto no capítulo XLV de $O$ fiel e a pedra, a epígrafe que o antecede parece casar perfeitamente com o conteúdo do capítulo. Afinal, os versos de Odisséia falam de mortos e Teresa sonhara com um morto $^{\text {clxi }}$. Todavia, ao contar um sonho para o marido, Teresa ouvirá o comentário 
cético; “- Também sonhei com minha mãe há dias. (...) Vinha proteger-me. Dar coragem. (...) Tudo foi sonho, Teresa. O meu, o seu. É um erro querer enxergar verdade nisso" (OFP, 256). E a observação de Bernardo nos fará refletir. Por que essa reação de descrença, depois de acreditar piamente que a mãe o visitara na forma onírica? Ao refletirmos sobre o excerto de Odisséia uma dúvida se nos acomete: os mortos dos versos emprestados a Homero são os odiados pretendentes, suas almas levadas pelo deus Hermes à morada de Hades... E eles haviam ido ao Hades se queixar (os “inocentes") contra a morte impetrada a eles por Odisseu. Ora, a maioria dos leitores do texto grego vai se pôr inteiramente contra essa estranha atitude. O herói da epopéia foi o instrumento para uma punição oriunda dos deuses. E por que Osman Lins - que emprestou tantas qualidades de Odisseu e as pôs em seu herói - usa justamente esse trecho - dos abomináveis pretendentes clamando por uma justiça que não podem usufruir - para ilustrar o capítulo em que Teresa se recorda do sonho com o filho morto e se lembra do pai falecido - e em que os esposos conversam sobre a possível ingerência dos mortos na vida humana? Então, nos lembramos que esse passo de Odisséia tem despertado acirrada polêmica entre os estudiosos da obra homérica. Em nota de rodapé da tradução de Antonio Pinto de Carvalho se lê:

"Desde Aristarco até V. Bérard, muitos argumentos de peso têm sido invocados contra a autenticidade da Rapsódia XXIV, e principalmente contra a autenticidade dos primeiros 205 versos, onde se descreve a descida à morada de Hades. Tais argumentos merecem grande atenção, de modo especial os que são tirados das contradições existentes entre esta última rapsódia e o resto do poema (...) "clxii

Dentre os argumentos citados, o tradutor lembra que sobre a quantidade de mortos ainda não sepultados, levantam-se suspeitas, pois a menção vai de encontro aos rituais fúnebres gregos de então e expostos nas duas epopéias homéricas: "Em nenhum outro passo os defuntos são admitidos na morada de Hades senão depois de terem sido 
sepultados”. Assim, Osman Lins cita um verso reputado apócrifo e incoerente, em relação ao todo de Odisséia, para anteceder um capítulo em que Teresa conta sobre um sonho com um morto que é falso (José não é José), portanto, um sonho apócrifo. Ao contar o pesadelo ao marido, ele dirá, tentando convencer a esposa de que não se pode acreditar na ingerência sobrenatural nos destinos do homem:

“- Também sonhei com minha mãe há dias.

- Como?

- Vinha proteger-me. Dar coragem. O sujeito pensa que é forte, que está de pé, com os pés firmes. Quando menos espera, sente que vai cair. Construção mal acabada, o homem. Uma parede solta, de pedras, rejuntadas com barro ordinário, que até uma chuva pode roer. Muito difícil a gente se convencer que está sozinho, que só pode mesmo contar com as próprias forças. Tudo foi sonho, Teresa. O meu, o seu. É um erro querer enxergar verdade nisso" (OFP, 256).

Bernardo aqui se faz descrente como Penélope. Contando acerca do sonho com uma águia devorando seus cisnes (a águia identificando-se como seu querido Odisseu) a desalentada Penélope diz: "Inexplicáveis, de fato, estrangeiro, são todos os sonhos, / faltos de senso, sem que se realize o que aos homens predizem" (Od, XIX, 560-1). No entanto, a narrativa homérica mostra que o sonho se realizará. A mulher de Bernardo, no entanto, fica reticente em descrer: olhar.

“- Era um sonho tão real! E tão ruim. Ele me acusava com o

- Também a minha mãe... Nem parecia sonho" (OFP, 258).

Teresa se lembrara do sonho durante todo o dia e se perguntara o significado das palavras iradas de José. Depois se questionara, coroando as palavras do esposo: "Seriam vãs as palavras do sonho, haveriam nascido apenas do seu terror?" (OFP, 259)

O sonho de Teresa demonstra realizar-se em outros objetos, mas não deixa de causar estranheza. Afinal, o menininho inocente que morrera como um anjo retornava com "maldade intolerável", proferindo com voz "cáustica" impropérios, falando em 
dois assassinos a ser castigados com a morte. Evidentemente, Teresa se apavora e se sente, juntamente com o esposo, alvo daquelas injúrias. Mas o sonho dá a impressão de ser um enigma: quem seriam, afinal, os dois assassinos que morreriam brevemente? Estaria o sonho querendo induzir o leitor a pensar que tais assassinos poderiam ser Nestor e Marvano [em vez de Bernardo e Teresa, como a princípio pode-se supor]?

E sobre as vozes internas? Vimos que ao efetuar um gesto simples, o de tomar o chapéu $^{\text {clxiii }}$, Bernardo é surpreendido com um pensamento que, na voz do narrador é "uma espécie de lembrança ou de pressentimento, a consciência de uma realidade malévola e obscura" (OFP, 303). Aqui observamos a incerteza de Bernardo quanto ao fato de estar no campo da realidade passada - a lembrança - ou da imaginação atemorizada - algum pressentimento. O esposo de Teresa chega a voltar-se para fora, tentando ouvir algo diferente: "Como quem busca ouvir, mal desperto, um grito de socorro só existente em sonho". A voz é explosiva, enérgica, "grito de socorro", mas quer se aproximar do irreal, pois "só existente em sonho" e "ele sabia que o chamado existia - real e enérgico - embora tão fugitivo, que fora impossível apreender a sua verdadeira significação. Entrevira uma verdade sem rosto". Enfim, é um grito com a evanescência do sonho, nunca apreensível de todo, nunca identificado plenamente. E Bernardo tinha a certeza de tê-lo ouvido. Mas o esposo de Teresa não compreende a mensagem do grito: “fora impossível apreender a sua verdadeira significação". A "realidade lembrada ou pressentida" trazida pelo grito, embora se assemelhe ao sonho, pertencendo à concretude, não se referia a ninguém, a nenhum fato presente: "aguardava-o além do lugar ou do minuto em que estava", ou seja, transpondo-se no espaço e no tempo. Bernardo compara essa intuição ao ato de entrar nas trevas, pelo caráter de opacidade da sensação. No final, a resposta direta, objetiva para as indagações do leitor: Bernardo pressentira a Morte: “(...) E lhe veio a certeza de que era 
a Morte que ele pressentia. Era ela que se aproximava, que se anunciava, rondando-o como nos livros de gravuras" (OFP, 303). Deparamo-nos, então, com um problema que se mostra desde o início do romance: o protagonista de $O$ fiel e a pedra parece meio deslocado de seu meio. Ou então, o autor não nos fornece - deliberadamente - todas as pistas de como transcorrera sua vida na infância. O leitor há de se perguntar, certamente: como um menino criado em meio comum, filho de pai festeiro e infiel - ao que se deduz da presumível paternidade de Cissone - e mãe reservada, da qual nada sabemos; cujo irmão se mostrara egoísta, ingrato, mentiroso e perdulário para com a família - como esse menino poderia ser tão íntegro? De onde viriam seus elevados princípios morais? E um rapaz que amava a vida livre de vendedor itinerante, lidando com gente sem conhecimento acadêmico, poderia ter tido, algum dia, apreço por "livros de gravuras"? Onde estariam esses livros nunca mencionados antes? Lucinda os teria apresentado aos filhos? Isso não se revela ao leitor... Pois esse homem simples, meio rude, meio valentão, era capaz de gestos de extrema delicadeza, como comprar revistas femininas para a esposa, ou refletir durante longo tempo, questionando-se acerca de nosso papel no mundo. Esse homem que é um ponto de interrogação, Bernardo, o nosso grande incógnita, o homem simples, não dado a arroubos comunicativos impressionarase na infância com a figura da Morte e na maturidade ainda tem pressentimentos que envolvem essa imagem. Que podemos dizer? Possivelmente tenha sido intencional essa exigüidade de dados biográficos de Bernardo. Também pode ter sido intencional as alusões a imagens do passado, sem que o leitor tome ciência completa dos fatos. Afinal, não serão somente esses os mistérios da obra. Lembremo-nos de que não conheceremos o assassino de Miguel, não saberemos quem é o autor dos ataques à propriedade de Bernardo, nem quem disparou os tiros na estrada. Muito menos saberemos de, de fato, Creusa traiu o esposo. 
Sobre a reflexão acerca do grito que talvez fosse do morto ${ }^{\text {clxiv }}$ interior, veja-se a ambigüidade das afirmações: Bernardo ouvia alguém o chamando "do campo" ou "do passado" ou era o "morto no corpo". Essa voz, no entanto, não profere seu nome - não é dirigida a ele, especificamente? E "talvez nem fosse uma voz" - a negação do dito retornando. E apesar de tudo, Bernardo "sabia que o chamavam" - voz inaudível. Também tinha a certeza de "que o apelo socorria-o", o chamado era uma "claridade", uma "corda", um "braço", metonímias para o que ele um dia esperara de Lucinda no rio Tapacurá. Como naquela ocasião tivera pesadelos subseqüentes, a "voz insistente" tem o poder de adentrar o mundo terrível dos sonhos maus, é voz que "rasga pesadelos" e "rompe o jugo do sonho". Por fim, é uma voz que "desamarra", remetendo ao sonho com Lucinda, em que Bernardo sentia desatar-se um amor claro... Afinal, de quem é essa VOZ dentro de Bernardo? Da mãe? Se a premissa for verdadeira, precisaremos encontrar em Lucinda uma atuação notável. Vejamos: Bernardo manifesta o desejo de desafiar o rio e a mãe o coíbe. Das águas revoltas, o jovem avista a mãe na margem, mas ela se queda inerte, observando o filho se debater contra a correnteza. Lucinda não mergulha, não grita por socorro, não acorre na direção de Bernardo. Depois da façanha, a mãe quer surrar o filho, pelo feito. Desiste de fazê-lo por comparar o corpo de seu menino ao de um morto (e lhe vir à mente a hipótese de perda do filho). Nas noites seguintes - e repletas de pesadelo, para o rapazinho -, a mãe contempla o filho dormindo - mais uma atitude neutra, embora imersa em mudas emoções. No sonho/aparição, a mãe não falará, pelo menos em voz audível. Assim, constatamos que Lucinda, como mãe humana, não é a protetora, no sentido estrito da palavra. Ela pouco interfere no destino do filho. E a idéia combina com o que ele, Bernardo, lê na atitude da mãe na beira do rio: “(...) ela parecia dizer que confiava nele e que estava certa de sua vitória. Você não será vencido, Bernardinho, nem pela sua fraqueza, nem pelo seu 
medo. Esse rio não pode com você [grifo nosso]" (OFP, 62-3). E lembremos que a mãe dissera: "- O que lhe salvou foi a sua firmeza, Bernardinho" (OFP, 63). Assim, essa voz interna não pode ser de Lucinda-mãe literal. E Osman Lins parece colocar um ponto final na discussão sobre essa ingerência da voz feminina e interna em Bernardo:

"Bernardo, como num sonho, tinha a impressão de que ia atravessar a nado um rio imenso. Era como há anos - quantos? - no Tapacurá. Mas agora não estava sozinho, tinha um amigo com ele [Antônio Chá] e a figura na margem - uma mulher - chamava-o. Ou era o chamado a sua presença? Reconhecia a voz, era a mesma que há pouco houvera clamado o seu nome, a que rasgava os pesadelos e salvava. E na hora do desgoverno, ele sentia que essa voz - essa mulher - era a sua lei, um edifício erguido, o seu clarão, seu firme bater de coração" (OFP, 310-1).

Esse "clarão" acompanhará Bernardo: "um grave clarão interior (a vida lhe parece, em certas horas, um velho bicho selvagem, adormecido a seus pés)" (OFP, 314). Essa lei interna também nos fará lembrar os comentários de Dodds acerca do instigante episódio em que Atena desce dos céus e puxa os cabelos de Aquiles, impedindo-o de matar Agamenon $^{\text {clxv }}$. Sobre o assunto, informa Dodds, tendo como base o trabalho de Nilson, apresentado em 1924:

“(...) a deusa só é visível aos olhos de Aquiles - ninguém mais a viu. O que é, enfim, uma clara indicação de que ela é uma projeção ou a expressão pictórica de uma advertência interior (...) E sugiro ainda que a advertência interna, assim como o inexplicável e repentino sentimento de potência e perda da capacidade de julgar é o germe a partir do qual pôde se desenvolver a idéia de uma maquinação divina.

Um resultado da transposição dos acontecimentos do interior do sujeito para o mundo externo é que a imprecisão é eliminada - o daemon indeterminado tem que se tornar um dado concreto, como um deus específico qualquer. Na Ilíada I, o daemon se transforma em Atena, a deusa do bom conselho. "(DODDS, 2002, p.22-3).

Responsabilidade do homem sobre seu destino

Apesar de Ilíada, Odisséia e Eneida expressarem a noção de que os deuses dirigem a vida humana, outro discreto conceito ligado ao destino se mescla na narrativa: 
a responsabilidade dos homens sobre seus atos ${ }^{\text {clxvi }}$. Embora Agamenon explique ter sido influenciado por Ate, Erínias e Zeus ${ }^{\text {clxvii }}$ no ato de tomar a cativa de Aquiles, e mesmo que esse último haja corroborado as palavras do rei, não podemos nos esquecer do que acontecera antes. Aquiles se enfurecera contra Agamenon, chegando às raias do descontrole emocional, sacando da espada e por pouco não matando o rei motivado pela raiva em função da atitude do atreide. Em nenhum momento Aquiles o justifica, aceitando o fato de estar sendo levado a agir por uma entidade divina; ao contrário, publicamente dispara contra Agamenon xingamentos fortíssimos não apenas por lhe tomar a jovem, mas também por outras atitudes nada corretas: a acomodação, nunca saindo às batalhas, mas fazendo outros lutarem por ele, a usura e falta de justiça no momento da partilha do espólio dos saques às cidades no entorno de Tróia (indo para um lugar em oculto e separando o melhor para si). Aquiles também roga à mãe divina, que interceda junto a Zeus para que o rei seja punido. Diante dessa reação indignada e com motivo, o que podemos entender? Somente uma verdade aparente: de que Agamenon, dotado de caráter no mínimo duvidoso, será culpado de suas ações. O conselho do arguto Odisseu provoca um olhar desconfiado da parte do leitor. A sugestão emitida $\operatorname{logo}$ após a cerimônia em que o rei se admite inocente do ato de desonra a Aquiles e realiza oferendas a Zeus, terá como objeto uma séria (embora polida) admoestação: que Agamenon buscasse nova atitude no futuro: "E tu, Atreide, no porvir, sê mais equânime / para com os outros. Não deslustra um basileu / desculpar-se ante alguém a que ofendeu primeiro" (Il, XIX, 182-4). E o leitor se questionará: se Agamenon poderia optar por se apresentar mais justo e humilde, essa não seria uma decisão racional, portanto não gestada e/ou gerida pelos deuses? Tais atitudes aparentemente antagônicas nos levam a considerar que o poema já antepõe discretamente a noção de responsabilidade do homem sobre seus atos, o que se verá 
mais intensamente na Odisséia. Nessa epopéia, o conceito da responsabilidade humana por seus atos será mais enfatizado, o que se apercebe logo, na reclamação de Zeus acerca da injustiça dos seres humanos em lhe atribuir autoria dos dissabores que sofrem: "Caso curioso, que os homens nos culpem dos males que sofrem! / Pois, dizem eles, de nós lhes vão todos os danos, conquanto / contra o Destino, por próprias loucuras, as dores provoquem" (Od, I, 32-4). Para elucidar a questão e lembrar a responsabilidade dos homens sobre seus atos, Zeus retoma o caso de Egisto, o amante da esposa de Agamenon. O infiel fora devidamente avisado por Hermes do que poderia lhe suceder caso levasse avante a desvairada paixão por Clitemnestra (segundo o mito, sentimento misturado com a ambição de tomar o poder do rei ausente, a lutar na guerra de Tróia). Embora advertido, Egisto fez ouvidos moucos à ordem divina e, auxiliado ou instigado pela amante, concretizou os planos macabros engendrados pelos dois, e, ao afinal, sofrera a morte pela mão de Orestes, o enteado (acompanhando o trágico fim de Clitemnestra): "Hermes assim o avisou; mas Egisto não quis convencer-se / dos bons conselhos de então. Ora paga por junto os seus crimes"( $O d, \mathrm{I}, 42-3)$. Desse modo, certa autonomia humana já se instala na Odisséia, embora, também se apresente a idéia dos deuses regendo os destinos. Basta lembrar que o herói máximo dessa epopéia, há de demorar dez anos para voltar a sua Ítaca e viverá dezenas de males por haver ofendido ao deus Poseidon ${ }^{\text {clxviii }}$. Enfim, na Odisséia, o homem começa a poder escolher entre um caminho e outro, com a consciência dos efeitos dessa escolha, o que se vê também no exemplo seguinte, em que Odisseu diz aos pretendentes: "Ora só tendes à escolha, ante vós, ou lutar, defendendo-vos, / ou conseguir, pela fuga, da Parca e da Morte livrar-vos" (Od, XXII, 65-6). 
Na Eneida vemos um herói em tudo comandado pelos deuses, mas cobrado quanto a atitudes tomadas ${ }^{\text {clxix }}$, o que transparece nas repreensões de Dido, bem como na culpa que perseguirá o herói por se preparar para abandonar a amada:

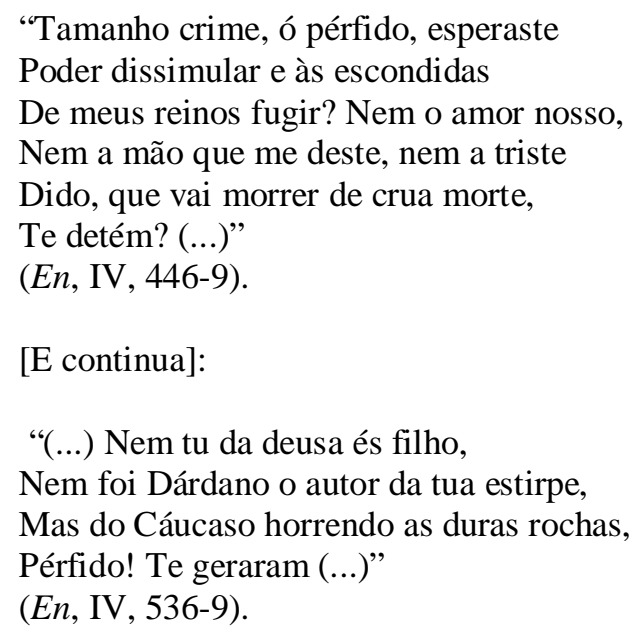

Pelo suicídio de Dido, Enéias carregará uma perene culpa: “Ai! A causa fui eu da tua morte!" (En, VI, 678).

Em O fiel e a pedra, Osman Lins também se aproxima dessa noção interposta nos poemas homéricos e virgiliano, a responsabilidade humana pelos seus atos. Afinal, em cada ato está implícita uma escolha. E isso fica transparente na fala de Bernardo à esposa: “- Mesmo agora, se tivesse que decidir, eu fazia o mesmo. Apesar de tudo, fazia de novo o que fiz. (...) Eu posso ter errado, mas não estava em mim continuar. Outro qualquer ficava, lavava as mãos.” (OFP, 4).

Essa visão da culpa dos homens pelo que lhes acontece aparece nas mesmas falas de Suzana e de Hutá Vilarim em que essas personagens se remetem a um destino imutável $^{\text {clxx }}$. A mãe de Teresa efetua comentário ácido acerca de Miguel Benício, sugerindo que o genro, sempre tão escrupuloso de seus atos, não deveria pôr-se em negócios com um homem de honestidade duvidosa: "É tão cheio de brios, seu marido. 
Não sei como ele quer negócio com Miguel, um homem sem caráter (...)” (OFP, 35).

Suzana, nesse caso, claramente atribui a Bernardo a autonomia de sua nova condição e as prováveis conseqüências: a aceitação da parceria com um homem sem caráter levaria, fatalmente, a problemas. E isso, de fato, ocorreu. Miguel tinha, efetivamente, um caráter duvidoso, basta lembrar a proposta feita a Bernardo, de transferir parte dos bens em uma falsa compra, com o objetivo de fraudar Creusa na ação de divórcio que ele, Miguel, intentava demandar, às ocultas. E tudo o que de mal vem depois decorre da decisão de Bernardo em aceitar consórcio com homem de tal natureza. Suzana ainda nos concede outros exemplos dessa visão acerca do destino (da responsabilidade humana sobre sua sorte). O primeiro, ao comentar sobre o provável envolvimento da esposa de Miguel Benício com o cunhado. A mãe de Teresa conjectura que Creusa poderia ter dado "azo" (OFP, 35), ou seja, dado motivo para o assédio de Nestor. O segundo exemplo está na acusação que faz à própria filha: se tivesse escolhido outro marido, sua sorte seria melhor: “- Você era para estar em outras águas, Teresa. Não foi para esses destinos de pobreza, que você foi educada. Não foi para isso que você esteve num colégio. Não foi para uma vida bruta" (OFP, 34). A resposta de Teresa a essas críticas também indicam a opção de escolha, ou o chamado livre-arbítrio operante. Quando a mãe reclama de o genro levar a filha para longe, a jovem diz que poderia decidir se aceitava ou não seguir o marido, mas optara pela primeira hipótese: “- Ele tinha o direito de obrigar-me a ir. Mas sou eu que não quero ficar" (OFP, 34). Erguendo-se resolutamente na defesa do esposo, fazendo lembrar à mãe que a ela, Teresa, era dado o direito de decidir entre uma e outra saída. Em seu íntimo, porém, Teresa há de trocar o tom ousado e desafiador com que se dirigia à mãe e se compadecerá de sua genitora, por compreender plenamente a razão de sua atitude dura frente a vida: Suzana seria tão cáustica exatamente por não haver pleiteado o direito e escolha quanto ao parceiro na 
vida. Os pais haviam-na obrigado a desistir do jovem amado porque ele era um artista pobre e sem perspectivas de sucesso. Suzana submetera-se e se tornara, para sempre, infeliz e rancorosa: "Ela não teve coragem de afrontar a família e ir para o homem a quem quis" (OFP, 35). Hutá Vilarim, depois de falar da sorte imprevisível de cada um, se contradirá quanto à noção de imutabilidade implícita no conceito geral de predeterminação ao invocar a proteção divina contra a probabilidade - terrível a seus olhos - de vir a ser traído pela mulher que viesse a escolher como esposa: "Que Deus o protegesse de vergonha igual..." (OFP, 40). Além de Suzana e Hutá, Miguel Benício também pode ser exemplo de expressão dessa idéia (a autogestão da própria trajetória de vida) ao se acusar pela infidelidade e afastamento de Creusa. Miguel pensava que a causa de todos os seus problemas conjugais era uma apenas - a escolha inter-racial ao decidir-se pela futura consorte: "Meu erro foi ter casado com mulher branca. Meu erro foi esse" (OFP, 89). Bernardo refutará o raciocínio, sugerindo enfaticamente que o erro de Miguel foi haver escolhido para esposa uma "moça bolinada" (OFP, 89), ao contrário dele, Bernardo, que ao buscar a mulher com que dividir sua vida intimamente, optara por Teresa, moça de "vergonha". De qualquer modo, o fator escolha, ainda entra como elemento preponderante do desenrolar da vida. A mesma conclusão se nos apresenta em outro ponto da narrativa, agora em relação a Bernardo. O narrador nos diz, como se o próprio jovem pensasse:

“(...) Bernardo poderia haver deixado o Engenho, seguido para uma sorte mais benigna. Nada o impedia de vender Princesa e o bezerrinho, acertar as contas com Nestor, pedir uma indenização pelos carás que breve estariam no ponto de colher. Ir embora em seguida, mais uma vez recomeçar.

Longe de fazê-lo, adquiriu um garrote e, na última semana de agosto, uma novilha, mesmo depois de saber, por intermédio de Bindinho, que um sujeito de Limoeiro, andava procurando um homem 'ainda que este só tivesse a cara e a coragem', para irem os dois buscar um lote de cavalos na Bahia. Estaria cansado de tantos recomeços? Ou, em seu íntimo, acreditaria tão profundamente na ligação de Nestor com o seu destino, que o 
aguardava ali, resignado e tenso, como um caçador que esperasse algum fantástico, infalível e terrificante animal, enviado pela malícia do demônio, para matá-lo ou morrer ante o clarão de sua arma? Jamais soube dizê-lo - e nem foram perguntas, essas, que ele formulasse. Simplesmente, por uma exigência invencível e, como as raízes de um sonho, nunca revelada, foi ficando. Motivos para voltar para a Vitória, ainda que sem meio de vida, sobejavam. Mas ficou" [grifo nosso] (OFP,121-2).

Note-se como o narrador coloca a questão: Bernardo estaria cansado de "tantos recomeços" ou resignava-se, acreditando estar Nestor ligado ao seu "destino"? Olhando pelo prisma da causalidade, Bernardo parece provocar todas as situações que se instauram em sua vida:

- A opção de abandonar as estradas leva ao emprego na cidade.

- A decisão de sair do emprego acarreta falta de meios para o tratamento do filho.

- Em virtude dessa carência o menino morre. Por causa da demissão e morte do filho Bernardo suscita a ira dos concidadãos.

- Devido a essa ira Bernardo - não consegue outro emprego. Em razão da penúria pós-demissão e da firmeza de princípios de Bernardo e ira dos demais homens da cidade Miguel oferece o arrendamento do armazém.

- Pelo bom relacionamento entre dono e arrendatário, Miguel pede o favor da falsa compra de bens.

- Pelos princípios morais Bernardo se nega a prestar o favor.

- Porque Bernardo não concorda com a proposta Miguel passa as terras para o irmão.

- Talvez por conta da falsa compra Miguel morre.

- Em razão da morte de Miguel e da falsa compra Nestor expressa o desejo de levar também o gado dos herdeiros.

- Por causa dos princípios morais Bernardo se opõe. 
- Em virtude da oposição Nestor se torna inimigo ferrenho de Bernardo.

E assim a história prossegue: toda a violência sofrida por Bernardo e sua esposa decorrem de sua atitude ostensiva de enfrentamento em relação a Nestor. Qualquer um diria que Bernardo - ele mesmo - provocara tudo o que lhe acontecera, incluindo aí a morte do filho. E isso aparece em frases dos demais personagens e até dele mesmo. Gumercindo lhe diz: “- Você com a sua intolerância! Quem sabe! É preciso ser cordato, tratar bem as pessoas" (OFP, 155), fazendo alusão à probabilidade de se alterar a maneira como os outros nos tratam e, conseqüentemente, mudar o rumo dos fatos. Olhando pelo viés da responsabilidade sobre os atos, haverá momentos em que Bernardo se manifestará não tão submisso ao "destino". E um exemplo dessa rejeição aos ditames da vida ocorre depois da morte de Miguel, após encontrar-se com o amigo Bindinho (aquele que lhe aconselha a manter uma atitude submissa em relação aos ditames do destino). Em pensamentos Bernardo considerará a não aceitação da vida como ela se apresenta: "Muitas águas correram sobre mim, estou ficando velho, caio sempre, volto sempre, recomeço. 'A vida é assim mesmo, dia bom, dia mau; é conformar-se' " (OFP, 98). E, lembrando a frase de Bindinho, acrescenta: "Não". E a veemência da negação, com toda a força agressiva, transparece no ato de esporear o pobre animal de montaria, sem nenhum motivo. Em outro momento, o enfrentamento dos acontecimentos futuros parece ser a tônica. $O$ destino não estaria, então, determinado, já que Bernardo poderia destruir com sua atitude o mal "por vir": "Um amargor nunca sentido minava o seu espírito (...). Desejaria convencer a si próprio de que todo o mal, vindo ou por vir, estaria aquém de sua altura e que poderia resisti-lo, ainda que fosse mais grave e mais extenso" (OFP, 125). Assim, Bernardo tanto é apresentado como um ser regido pelo Destino (um Aquiles, um Enéias?) como se 
questiona sobre suas decisões e ainda advoga o livre-arbítrio. Com entender essa ambigüidade? A impressão que se tem é de que, aludindo à epopéia de Virgílio e, indiretamente às homéricas Ilíada e Odisséia, Osman Lins não se calará ante as incógnitas existenciais, mas falará sobre elas, abordando o tema da morte e do destino ora de uma face, ora de outra. Como Homero e Virgílio, o pernambucano apresentar-seá incoerente à primeira vista; todavia, seu objetivo é promover uma reflexão acerca dos grandes fatos da vida e dividir com o leitor as inquietações sobre os mistérios do Universo. No final da narrativa, porém, o autor insere sua conclusão sobre o destino dos homens. As duas frases dos exórdios que introduzem os capítulos finais comprovam a face escolhida. No capítulo XLVIII em que se narra a transformação de Ascânio, de menino a homem, o exórdio é composto da frase: "O menino decide o seu destino" (OFP, 275), ou seja, Ascânio fecha sua história ao efetuar a migração dos ídolos do passado. No capítulo seguinte, que descreve o balanço final entre Nestor e Bernardo, encontramos a seguinte inscrição: "O homem decide o seu destino" (OFP, 283), explicitando a atitude de Bernardo depois de muito refletir sobre os fatos de sua vida no Surrão, bem como na atitude que mantivera para com Nestor. Bernardo começa a pôr um ponto final na sua trajetória de vida, escolhendo controlar seus impulsos - os maiores inimigos - e não ter medo: "Fora o bastante para que certos fios se ligassem, desvios do sentir e do pensar fossem notados, retificados, para que ele visse e agisse melhor" (OFP, 284). Finalmente o protagonista compreende as reais intenções de Nestor e chega, enfim a uma condição de firmeza e serenidade, "a uma atitude resoluta e calma" (OFP, 284). O esposo de Teresa ainda pensa que Nestor pretendia aterrorizá-lo (quase o fazendo), mas se depararia com um outro Bernardo, senhor de si e absolutamente sob controle emocional: 
"Encontraria isto: Bernardo Vieira Cedro, um homem cujos impulsos mais rebeldes estavam afinal governados, dentro do seu mando. Até então, pensava, fora exatamente como aqueles frades de quem falava Lucinda, olhando o quadro na sala de jantar, os gordos frades bebedores de vinho: monstros cuja sede aumentava, à medida que bebiam. Mas isto, felizmente, passara" (OFP, 284)

E tal efetivamente ocorre. Nestor é quem se demonstra fraco diante da força do barraqueiro. O grande e poderoso inimigo fisicamente estará em frangalhos: o "cobreiro" a atacá-lo furiosamente, o corpo sentindo a carga psicológica da derrota em subjugar Bernardo. Vencido e humilhado, em vão há de implorar pela cooptação e submissão do outro: “- Vamos ser amigos. Aceite o meu amparo” (OFP, 294).

Menino e homem decidindo seu destino nos levam à liberdade absoluta defendida por Sartre e à possibilidade de escolha, aliás, condição que já Pascal ${ }^{\text {clxxi }}$ dizia ser impossível evitar. Menino e homem serão ambos responsáveis por seu destino, pois que já o eram por suas escolhas, inclusive dos princípios de vida que os regeram.

\section{Caráter e destino}

Até aqui vimos o quão intensa é a aproximação entre o romance osmaniano de 1961 e as epopéias citadas, no aspecto dos conceitos sobre o destino - a imutabilidade do mesmo, a responsabilidade dos homens sobre os atos cometidos. E a segunda linha de pensamento aproxima-se da conhecida fórmula de Heráclito: “o caráter do homem é seu destino" ou "o destino do homem é seu caráter" clxxii. Aristóteles parece concordar com Heráclito ao dizer que existe ligação entre o caráter e o destino das pessoas. Palavras enunciadas sob elocução pensada e que denotem escolhas - e não simplesmente ditas aleatoriamente - deixam entrever o caráter, as ações advindas de tais escolhas trazem lá suas conseqüências. De certo modo todos nós sabemos que isso pode ser um fato. Corroborando o filósofo grego, uma pessoa pode se tornar próspera ou 
decadente, feliz ou infeliz, por conta de seu caráter que se revela nas palavras e ações praticadas no decorrer da vida.

Na literatura, ainda confirmando o exposto por Aristóteles, o mesmo se dá com as personagens: o caráter de um herói coaduna-se às suas ações, sendo essas as responsáveis pelo sucesso ou fracasso de sua trajetória. Aristóteles diz: "Os homens possuem diferentes qualidades, de acordo com o caráter, mas são felizes ou infelizes de acordo com as ações que praticam" clxxiii. Profundo admirador de Homero, Aristóteles fala da tragédia como próxima à epopéia, por ambas imitarem a vida, enfatizando os "seres nobres", ou seja, enfocando personagens de caráter superior aos homens comuns. Aristóteles preconizava ser o caráter um dos aspectos preponderantes no arcabouço da produção poética do gênero e defendia a tese de que à noção de caráter imbricava-se discernimento e escolha. O herói, portanto, mostraria seu caráter pelas falas e ações, das quais se depreendessem opções pesadas antecipadamente:

"Caráter é aquilo que mostra a escolha numa situação dúbia: aceitação ou recusa - por isso, carecem de caráter as palavras quando nelas não há absolutamente nada que o intérprete aceite ou recuse. Há idéias quando os intérpretes dizem que algo é ou não é, ou expressam alguma coisa em termos genéricos" clxxiv.

Aristóteles fechava o raciocínio preconizando que, assim como na vida à qual imita, a tragédia terá êxito se as ações determinadas pelo caráter e pensamento conferirem credibilidade aos personagens:

"Como a tragédia é a imitação de uma ação, realizada pela atuação dos personagens, os quais se diferenciam pelo caráter e pelas idéias (porque qualificamos as ações com base nas diferenças de caráter e idéias), segue-se que são duas as causas naturais das ações: idéias e caráter. E dessas ações se origina a boa ou má fortuna das pessoas. A fábula é imitação da ação" clxxv . 
Ao compor seu romance $O$ fiel e a pedra, tão fundamentado no caráter do herói $^{\text {clxxvi }}$, o autor aproxima-se, como vimos, de Ilíada e Odisséia, inserindo aqui e ali noções acerca do destino como o senhor absoluto da caminhada humana, mas, por outro lado, perguntando uma vez ou outra se tudo ocorreria assim mesmo ou não, sugerindo a responsabilidade dos homens sobre seu destino ou apegando-se à visão racional, mas não muito clara, de Heráclito. Para discutir tais defesas, Osman Lins insere nos lábios de seu protagonista, de outras personagens ou do próprio narrador, frases que denunciam a possível implicação entre o destino e o caráter de Bernardo. Não nos esqueçamos de que, ao tentar explicar para a esposa porque deixara o emprego e percebendo a difícil condição a que submetera a família, Bernardo concluiria: “- Mas eu tenho culpa" (OFP, 4). Enfim, o protagonista poderia ter alterado o ritmo de sua vida? Poderia ter evitado os males que causara a si, a Teresa, ao filhinho e demais familiares? Ele mesmo se questionara sobre certas atitudes que havia tomado, e que o induziam a pensar suas ações como sendo relacionadas ao destino. Ao perceber a hostilidade grassando no Surrão, em vez de ir-se embora, Bernardo ostensivamente permanecera no lugar e ainda fincara raízes adquirindo maior número de animais. Ele mesmo se questionava quanto às razões daquela aparente insensatez: acomodação ou destino? Vejam-se as palavras inquiridoras do narrador:

"Estaria cansado de tantos recomeços? Ou, em seu íntimo, acreditaria tão profundamente na ligação de Nestor com o seu destino, que o aguardava ali, resignado e tenso, como um caçador que esperasse algum fantástico, infalível e terrificante animal, enviado pela malícia do demônio, para matá-lo ou morrer ante o clarão de sua arma? Jamais soube dizê-lo - e nem foram perguntas, essas, que ele formulasse. Simplesmente, por uma exigência invencível e, como as raízes de um sonho, nunca revelada, foi ficando". (OFP, 121-2).

O leitor poderia se perguntar: a tal "exigência invencível" de Bernardo seria externa ou interna? Bernardo parece balançar-se entre se apresentar como um ser 
autônomo e heterônomo ${ }^{\text {clxxvii }}$. As razões para a permanência no Surrão, nunca lhe seriam reveladas (tais quais as raízes de um sonho) como supunha Bernardo? No entanto, o narrador do romance não nos esconde que as raízes do sonho com a travessia do rio Tapacurá formam um rosário imbricado à autonomia: desafio, ousadia, livreescolha, força interior. Concluímos, dessa maneira, que nesse ponto da história Bernardo ainda se questiona quanto ao que o move, efetivamente - sua vontade ou forças sobrenaturais.

Bernardo mostrará por diálogos, reflexão e conduta, a dubiedade na crença do destino: em certos momentos expressará frases que denotam a noção do destino imutável, em outros se acusará de haver cometido enganos nas decisões. Vejamos como exemplo uma parte da conversa com a esposa, em que, mais uma vez, lamenta-se pela vida difícil que lhe oferece: “(...) Tudo que você tem sofrido, é por causa da pobreza. Da minha pobreza e da minha dureza. Mas eu sou assim (...). Não posso ser de outro modo" (OFP, 257). Bernardo atribui a situação ruim que o casal vem atravessando a seu caráter inflexível, que ele não conseguia alterar. E tal rigidez? Seria instigada sobrenaturalmente ou parte de sua personalidade?

E quanto à monumental ira que acomete Bernardo, crescendo assustadoramente dentro dele e fazendo-o desafiar o desenrolar dos fatos da vida, como no caso em que abre a porta ao bando de Ubaldo clxxviii $^{\text {Alimentando essa ira Bernardo encaminhava-se }}$ para a perdição, a morte como o fim certo de alguém que não fazia concessões. Bernardo percebe o fato, intensamente, e se despede do mundo com a resignação dos que são fiéis aos princípios.

A Ilíada mostra, também, um destino dúplice para Aquiles. Ele podia viver bastante tempo e terminar a vida numa velhice tranqüila dos que cumpriram serenamente sua parte; ou morrer precocemente, na força da juventude dedicada às 
batalhas e, portanto, coroado de glória. Aquiles ${ }^{\text {clxxix }}$ sonha com uma vida longa, porque tem prazer em viver; mas como todo guerreiro grego, gostaria de que seu nome passasse à posteridade como o de um grande herói. $\mathrm{O}$ fator que põe fim a tal conflito é a ira. Por causa dela Aquiles se afasta da guerra; o afastamento gera fragilidade no exército grego; a fraqueza nas fileiras produz mortes; Pátroclo acode seus co-irmãos; pela morte do amigo Aquiles decide seu fim. Por ocasião da embaixada despachada por Agamenon, a fim de convencer Aquiles a superar a mágoa e retornar aos campos de batalha, Odisseu sugere a Aquiles ser mais maleável, rememorando um conselho de Peleu:

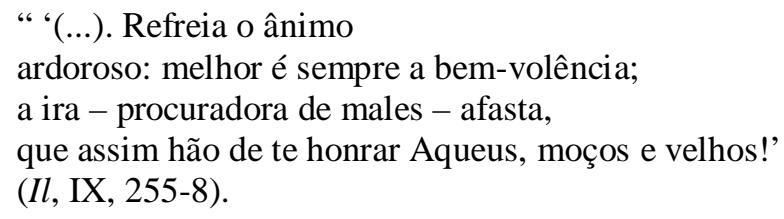

Odisseu completa: “(...) / Doma a cólera, doença-do-coração. (...)”(Il, IX, 260).

No caso de Aquiles, a ira provocaria o cumprimento do destino "tecido pelos deuses", por conta disso, ao morrer Pátroclo, tanto chorara a mãe de Aquiles - o filho seguiria, ela o sabia, para a revanche, matando Heitor e aproximando-o do final trágico.

O caráter decidirá, de modo semelhante, o destino do Messias citado no salmo $^{\text {clxxx }}$. A honradez com que pautou Suas ações e palavras fizeram dEle um Ser indesejável para muitos e excluído de seu convívio. E esse Messias, usado como imagem resgatada no salmo da epígrafe, esteve acuado pelos inimigos por destoar deles no proceder e falar. No capítulo ornado pela citação bíblica, Nestor Benício, representação inconteste do Mal, havia influenciado sutilmente a todos os moradores do Engenho e esses passaram a hostilizar Bernardo, por seu lado, representação do Bem: “... seu desquerer [de Nestor Benício] medrava no pessoal do Surrão” (OFP, 200). Bernardo imagina que os moradores odiavam a representação das possíveis qualidades: 
a arrogância, a ousadia de querer ser diferente, de não enxergar seu devido lugar (o que eles faziam, mesmo com ódio):

"É certo que talvez nem o odiassem verdadeiramente, e sim a um mito de que ele seria a encarnação: o ódio comum, feito de ressentimentos dispersos e cego à verdadeira natureza de seus atos, adensando-se contra o mito, contra a sua alma factícia, mais real para os moradores do Surrão que a sua alma autêntica, e que os diálogos e os silêncios deles elaboravam a seu modo, tornando-o cada vez mais execrável" (OFP, 206).

Como o cordeiro sacrifical simbolizava Jesus Cristo e Este era o antítipo do cordeiro; Bernardo é mitificado e passará a representar as qualidades que Nestor abominava - e os trabalhadores e capangas, na esteira da vontade do patrão, também. 


\section{CONCLUSÃO}

Do mito para a razão

Como vimos à exaustão (ou quase), Osman Lins afinou seu texto à cadência das epopéias greco-latinas e o fez levado, pressupomos, por motivos vários; um deles é certa "modernidade perene" de tais poemas, no sentido de visão de mundo precipuamente; fato que só podemos entender quando renunciamos a determinados preconceitos. Poderíamos qualificar esses preconceitos em dois grandes obstáculos cerceadores de uma análise criativa: a visão ocidental quanto à religiosidade amalgamada nas belas páginas de Homero e Virgílio e a não-aceitação de um olhar comparativo entre obras que se pautam pelo que costumeiramente denominamos distanciamento temporal. Se nos libertamos desses impedimentos dúplices, nos damos conta de que é possível entender o projeto de Osman Lins ao recortar tanto excertos quanto imagens magníficas da literatura grega, romana e outras para compor seu romance de 1961. O escritor pernambucano vislumbrou uma afinidade intensa da história de vida dos heróis passados com a história de vida dos heróis de sua infância. Osman Lins não sentiu receio de seu romance soar descabido ao ser iluminado com a modernidade ancestral. Dodds aborda essa espécie de contemporaneidade que a visão de mundo grega pode oferecer:

“Apesar da falta de liberdade política, a sociedade do século III a. C. era de diversos modos a maior aproximação de uma sociedade aberta que o mundo havia conhecido, estando mais próxima do que qualquer outra, até mesmo daquilo que veríamos nas sociedades modernas" (DODDS: 2002, p. 238).

E se a epopéia está fundeada no mito, o mito é fascinante para Osman Lins, embora, quase paradoxalmente, o autor se apresente como essencialmente racional. 
Osman fará com que suas personagens, bem como as vozes narrativas, resvalem pelo mito, mas retornem, assim que possível, para a realidade. Como vimos, o autor estará sempre sugerindo uma saída fincada no que é plausível, segundo o que a realidade se nos apresenta. Um exemplo dessa visão decorre num fato. Dizendo que a voz, que o narrador nos levara a concluir que fosse a mãe de Bernardo, trazendo avisos do além, era a sua lei interna, Osman Lins deixa a "idade do mito" e adentra para a da "razão". E o germe de tal visada já se esboçava no episódio do rio Tapacurá, quando o menino imagina que a mãe lhe dizia o que, efetivamente, formulava - mensagens de perseverança e força. Dodds comenta sobre a mudança de pensamento de Homero a Aristóteles:

\begin{abstract}
"É certamente nesta idade que o orgulho grego da razão humana atinge sua expressão mais confiante. Devemos rejeitar, diz Aristóteles, a velha regra que aconselhava humildade, convidando o homem a pensar em termos mortais (...) pois o homem possui dentro de si algo divino - o intelecto - e até onde ele puder viver desta experiência intelectual, ele viverá como se não fosse mortal" (DODDS: 2002, p. 239, citando Ética a Nicômano, 1177 24-1178)
\end{abstract}

No entanto, Osman Lins admite que o mito é o ingrediente mágico para a literatura. E ele agudiza essa tangente em seu romance de 1961. Para entender a instigante inserção, precisamos novamente nos recordar das epopéias, pois nelas o autor se baseou seu olhar ao compor O fiel e a pedra.

Na Ilíada, Helena dirá a Heitor qual seria o objetivo da ingerência divina na sua vida e na de Páris. A poesia, a literatura, essas sim teriam sido os grandes motores para tudo o que acontecera:

\footnotetext{
“(...) Tens

o coração num círculo de mágoas, por causa desta cadela que eu sou e do louco

Páris, a quem Zeus fado sinistro impôs, para
} 
que, ambos, sejamos tema dos vates vindouros"

(Il, VI, 354-8)

Carlos Alberto Nunes, na Introdução da Odisséia traduzida por ele comenta esse

aspecto:

"Seja qual for a idéia que fizermos do autor da Ilíada e da Odisséia, ressalta como traço fundamental de sua individualidade o entusiasmo com relação à importância da poesia e do valor da imaginação criadora. Homero sabia que os grandes heróis do passado só alcançam a imortalidade da fama por intermédio da poesia. Na Ilíada Helena declara expressamente que todas as desgraças que lhe acompanhavam os passos, no jeito de miasma contagiante, o entrechoque de dois continentes, que iria culminar com a destruição de Tróia e a morte de seus defensores, só tinham sido determinadas pelos deuses para que não faltasse assunto para os vates excelsos." clxxii

Além disso, ao lermos as belíssimas páginas de Ilíada, Odisséia e Eneida, veremos os heróis que modelam o perfil de Bernardo (Aquiles, Odisseu e Enéias) sãonos mostrados cantando (ou contando) epopéias, bem como as ouvindo, enlevados. Vejamos como se mostra o canto nesses poemas épicos mencionados.

As epopéias gregas citadas por Osman Lins anunciavam-se como um canto, cujas palavras narrariam as ações do herói, assim como mostrariam seu caráter e destino, como se inicia em Ilíada, cujo enfoque supremo é o caráter do herói máximo de suas páginas:

"Canta-me, ó deusa, do Peleio Aquiles

A ira tenaz (...)"

$(I l, I, 1-2)$.

Ou Odisséia, olhar centrado para o destino de seu herói:

"Canta, ó musa, o varão que astucioso,

Rasa Ílion santa, errou de clima em clima, viu de muitas nações costumes vários” 
$(I l, I, 1-2)$.

De igual modo se apresenta a epopéia latina tomada de empréstimo, Eneida, que objetiva contar da missão/destino de Enéias:

"Eu canto as armas e o barão primeiro, Que trófugo de Tróia por destino, À Itália e de Lavínio às praias veio" (En, I, 1-3).

Da mesma maneira o faz a produção épica camoniana, por seu lado, enfatizando as ações dos portugueses:

\footnotetext{
"As armas e os barões assinalados, Que da ocidental praia Lusitana, Por mares nunca dantes navegados, Passaram além da Taprobana, (...) Cantando espalharei por toda parte" (Os lus I, 1-6).
}

E também, Geórgicas - chamada epopéia da criação, serão classificadas como um canto, cujo cerne é a cosmogonia:

\footnotetext{
"O que as messes alegre; (...)

(...) e quanto de ciência o parco enxame pede, e ensina a experiência, Mecenas, vou cantar" (Geórg I, 3-5)

E encerrando-se com as palavras:

"Cantei lavoura e gado, árvores e os méis" (Geórg IV, 747).
}

Além de as epopéias trazerem o canto como arauto de seu conteúdo, no interior de sua estrutura esse elemento se faz presente, na maioria dos casos. Na Ilíada, um dado 
surpreende pelo inusitado: o mais forte dos guerreiros, também o mais impetuoso e irascível, surpreende o leitor com uma face quase inacreditável: seu lado sensível e artístico. Veja-se como a famosa embaixada de reconciliação o encontra:

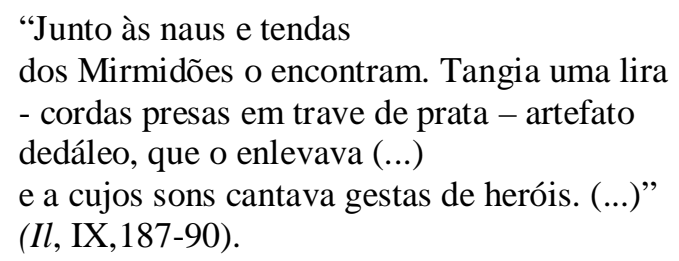

E Aquiles se enleva com a canção, cujo tema é as "gestas dos heróis", ou seja, as epopéias. O canto o faz inserir-se na pele das personagens e, de certo modo, viver as façanhas das guerras. Ao cantar as gestas dos heróis, Aquiles, ao mesmo tempo, ouve e reitera as vozes do passado.

Poderíamos dizer que na Odisséia o canto está inserido na narrativa e sendo, ele mesmo, a própria narrativa - o canto dos aedos conta algo da vida pregressa do herói; depois, o herói do canto irá cantar sua história; a história que conta tudo isso é em si mesma um canto. Ou seja, o canto é o ingrediente da receita, a maneira de preparo e o produto final. O canto volta-se para si mesmo. A primeira menção ao canto é em relação à festa de casamento dos filhos de Menelau e Helena. Telêmaco participa dos festejos em que um "aedo divino" cantava ${ }^{\text {clxxxii }}$. Denotamos com o texto que as narrativas eram, muitas vezes, acompanhadas por dança, arte que Homero sempre valorizará, mencionando, como no banquete de Alcínoo. Deusas, ninfas e outros seres maravilhosos também cantam; alguns, apreciando fazê-lo enquanto tecem. Observe-se o exemplo de Circe, muitas vezes chamada "canora". A voz de Circe é "amorável" e, ao som do ritmo de sua música, tece uma tela "imortal", descrita como obra de grande esplendor. Em um ponto perigoso da viagem, as sereias cantam uma música ouvida apenas por seletos ouvidos - de Odisseu, por exemplo. A música é inebriante e tem o 
poder de entorpecer os sentidos, levando o ouvinte a se dirigir às cantoras e com as mesmas ficar eternamente. E o que as sereias cantam ou qual é o tema de sua canção? As belas sereias cantam - exatamente... - as aventuras do "famoso Odisseu": "Todas as coisas sabemos, que em Tróia de vastas campinas, / pela vontade dos deuses, Troianos e Aquivos sofreram" (Od, XII, 189-90). E como podemos ler esse interessante dado? Nossa tese é de que, caso o herói se deixasse fascinar pelas aventuras do passado, a melodia (sua história) tornar-se-ia um perigo, pois o fascinaria e atrairia indefinidamente ao passado. Odisseu, ao contrário, se quisesse retornar à pátria, precisaria olhar para o futuro, preparar motivos para novos cantos... Advertido desse poder, Odisseu pede para que o amarrem ao mastro, protegendo ainda os ouvidos com cera $($ Od, XII, 200).

A Odisséia também menciona dois aedos importantes: Fêmio e Demódoco. Fêmio é o cantor do reino de Ítaca e os pretendentes exigem que toque nos banquetes. O aedo itacense cantava os feitos de Odisseu, levando Penélope às lágrimas. Com a chegada de Odisseu e o morticínio imposto aos nefastos hóspedes, o cantor implora pela vida, apontando a importância dos artistas em todas as sociedades:

\footnotetext{
"Arrependido virás a ficar se matares a um vate, cujas canções sempre foram dicadas aos deuses e aos homens. Fiz-me por mim, tão-somente, que um deus em minha alma ditou-me muitas canções. Dá que possa cantar junto à tua pessoa como ante um deus; não procures, portanto, privar-me da vida" (Od, XXII, 345-9).
}

Demódoco, o cantor que enleva os convidados de Alcínoo, com as canções instigadas pelo furor em seu peito. O "divino Demódoco" (Od, VIII, 43) era cego e o autor de Odisséia, porém, lembra a potencialidade e diversidade dos dons, mesmo na fragilidade e deficiência: 
"Já pelo arauto trazido o cantor divinal se aproxima, que tanto a Musa o distingue, e a quem os males e bens concedera: tira-lhe a vista dos olhos, mas cantos sublimes lhe inspira"

(Od, VIII, 62-4).

Outro aspecto interessante com relação a Demódoco é o fundamento de seu canto - "o furor" - ou seja, a indignação diante de alguns fatos da vida (ou seria uma reflexão acerca dos mesmos?). Podemos entender que Homero advoga a tese de que o artista é levado a cantar porque algo dentro dele não consegue se calar ante os episódios surpreendentes [ou revoltantes?] da vida. Ou então, o "furor" seria uma espécie de fervor à poesia épica - a literatura. Sobre os temas dos cantos de Demódoco, pelo menos os entoados durante o banquete na corte de Alcínoo, a guerra de Tróia é o principal:

"a Musa logo o incitou a falar sobre os feitos dos homens, gestas de heróis, cuja fama o alto céu, nesse tempo, atingira, a dissensão entre Aquiles pelida e Odisseu, tão falada" (Od, VIII, 73-5).

A reação de Odisseu ao canto de Demódoco é de enlevo e admiração, palavras que podem ser estendidas como uma reflexão à arte em geral:

"Todos os homens que vivem no dorso da terra, os cantores sabem cultuar e os veneram, por verem que as Musas os prezam como a discípulos. Todos a casta dos bardos prezamos" (Od, VIII, 479-81).

Em seguida, o herói desafia Demódoco a cantar/contar as histórias "de acordo com os fatos", ou seja, o mais realisticamente possível. Demódoco acede e narra especificamente o quê? A guerra de Tróia, com ênfase na atuação de Odisseu. Ouvindo o canto, chora sentidamente, fato que não é passado despercebido ao anfitrião. Alcínoo instiga o hóspede a contar a causa de tanta comoção, já que, no seu entender, a narrativa 
não passava de uma lista de fatos impetrados pelos deuses - matéria para a poesia, simplesmente:

"Conta, também, o motivo de tanto afligir-te o imo peito ao escutares desgraças de Tróia, dos Dânaos e Argivos. Obra dos deuses foi tudo, que aos homens a ruína teceram, para que nunca aos vindoiros faltasse matéria de canto" (Od, VIII, 577-80).

Odisseu, então, se instaura como narrador e conta as aventuras e desventuras que marcavam sua vida até ali. Elas são a Odisséia... O rei Alcínoo constata as verdades em forma de canto:

"Não tens o aspecto, Odisseu, quanto mais todos nós te admiramos, de mentiroso ou embusteiro, do jeito de tantas pessoas que a negra terra alimenta e espalhadas se encontram no mundo, a urdir mentiras acerca de fatos jamais presenciados.

Tu, porém, sabes dar forma admirável aos teus pensamentos como um cantor eloqüente disseste-nos a narrativa dos sofrimentos do exército argivo, que teus, também, foram" (Od, XI, 363-9).

Novamente é elogiada a boa narrativa como dom do narrador fundeado na experiência - ao contrário de narrativas de "inventados". E o rei Alcínoo se enleva de tal modo com a narrativa de Odisseu que sugere a continuação da mesma madrugada adentro:

"Muito comprida é a noite hoje, infinita; ainda é cedo, por certo, para dormir no palácio. Ora os feitos nos conta admiráveis.

Consentiria em ficar até vir-nos a aurora divina, se suportasses, aqui no salão, teus trabalhos contar-nos" (Od, XI, 373-6).

Odisseu se demonstrará não somente um bom contador de histórias, mas também sequioso das mesmas, condição que se evidencia no Hades, ao pensar em um 
estratagema especial para fazer as mulheres contarem suas histórias, "conforme inquiria curioso" (Od, XI, 234): elas poderiam provar da iguaria ritualística - o sangue dos sacrifícios - se contassem antes a história de suas vidas.

Mais à frente, com Atena disfarçada, Odisseu volta a narrar, dessa vez, não os fatos reais, mas casos acontecidos apenas em sua imaginação, o que é considerado uma forma de mentira: "mas sem contar a verdade, narrando uma história inventada" ( $O d$, XIII, 254).

Ao retornar a casa, também acontecerá outra noite narrativa: Odisseu ouvirá com atenção a narrativa de Penélope e, em seguida, contará à esposa as aventuras pelas quais passara durante a ausência do lar ${ }^{\text {clxxxiii }}$.

Na Eneida e em Os lusíadas, o canto não tem o relevo das epopéias homéricas, mas no livro bíblico escolhido para ceder um excerto ao capítulo XXXVII, o qual narra o sentimento de acuação da parte de Bernardo, o canto é tudo: é a matéria de todo o livro.

Em O fiel e a pedra, como nas epopéias em questão, uma canção abre o romance e, como já vimos, canta o caráter do herói. A voz que enuncia a mensagem - "Agora (eu) conto a história"... - é a não identificada voz de um cantador, desses que povoam as feiras do Nordeste brasileiro, sendo uma espécie de irmão distante dos trovadores medievais, esses, por sua vez, os herdeiros culturais dos simpáticos aedos helênicos. Além do evidente talento musical e poético, da impressionante capacidade de memorização e do carisma pessoal desses artistas, as viagens a que se obrigavam a fazer tornavam-se fator de constante reciclagem intelectual e artística. E, sem sombra de dúvida, os viajores são os que mais têm histórias para contar, parafraseando Walter Benjamim, ao lembrar que as melhores histórias escritas são as que se aproximam das contadas oralmente ${ }^{\text {clxxxiv }}$. Na maioria desse tipo de narrativas há o desejo latente de 
expressar uma experiência exemplificadora, enfatizando a atitude pragmática do narrador. $\mathrm{O}$ estudioso lamenta que a prática de aconselhar esteja acabando, atribuindo tal circunstância ao fato de que a experiência de vida está carecendo de moldes comunicáveis, ou seja, estamos nos tornando insípidos na arte de enxergar caminhos e verbalizá-los, tanto para os outros, quanto para nós mesmos. Essa constatação leva à outra: a arte da narrativa está fenecendo porque a sabedoria também está deixando de existir. Na opinião de Benjamim, a arte de narrar se esvai por conta do aparecimento de uma nova produção literária que, apesar de fincada na narrativa primordial, dela procura se distanciar consubstancialmente - o romance ${ }^{\text {clxxxv }}$. Ao fazer uso de um trecho de canção popular, Osman Lins credita imenso valor à figura do narrador oral, implicitamente entoando loas à própria arte de narrar: o cantador anônimo, de uma canção anônima, será o narrador de $O$ fiel e a pedra [ou o narrador do romance osmaniano é o cantador nordestino?]. Esse cantador/narrador adentrará o estatuto épico, pois falará - ele apresenta - de um homem "valente", portanto, um herói. Esse pequeno trecho de uma canção ouvida talvez nas feiras de Vitória, cantada por um repentista itinerante é mais um dos elementos que dialogam com Ilíada, Odisséia, Eneida, Os lusíadas, Geórgicas e Salmos. Em outros exórdios encontraremos canções, como o salmo citado no capítulo XXXVIII de $O$ fiel e a pedra, é um antigo canto hebraico ${ }^{\text {clxxxvi }}$ (mostrando caráter e destino do Messias); a frase do exórdio do capítulo XXIX do mesmo romance parte de uma melodia de Catulo da Paixão Cearense: A lua nasce por detrás da verde mata ${ }^{\text {clxxxvii }}$ (também tratando do destino de uma personagem secundária, o advogado Teles); a expressão poética "Chove, chuva”, no capítulo XIV, remetendo a uma modinha que o povo cantava ${ }^{\text {clxxxviii }}$ (lembrando que o "destino" - a tragédia devido a tempestade - poderia ser alterado). Assim, como já sobejamente comentado, antes de alguns capítulos deparamo-nos com pequenas proposições à moda das epopéias greco- 
romanas. Além do canto nos exórdios e nas epígrafes neles inseridas, no interior dos capítulos do romance $O$ fiel e a pedra, o canto estará sempre atuante, seja retomando Fêmio ou Demódoco ${ }^{\text {clxxix }}$ ou os heróis-narradores, Aquiles, Odisseu, Enéias. E isso se apresenta em várias modalidades: na música que alguém canta em tom malicioso ${ }^{\mathrm{cxc}}$, por exemplo, ou nas palavras do narrador:

"Sem nenhum esforço, Bernardo refletiu (um pensamento claro, como em certas canções que ele se surpreendia a assoviar em seus dias mais felizes - há quanto não acontecia? - ignorando em que tempo e lugar as escutara, mas sabendo que não lhe pertenciam e que nunca voltaria a recordá-las) refletiu que a vida humana era insegura (...)" (OFP, 143).

Enfim: um pensamento extraído de uma canção perdida no tempo e no espaço, canção do mundo, sem dono definido [canção de todas as gentes?] - assoma o herói: a vida humana é insegura (também um pensamento recorrente nas epopéias, como o já aventado). Por outro lado, assemelhando-se a Aquiles, Odisseu e Enéias, Bernardo conta suas narrativas. E seu ouvinte preferido é o sobrinho. Notemos a inserção de um desses momentos especiais, plasticamente decorado pela poética sonoridade da noite chuvosa:

"O rumor da chuva se tecia no cantar ininterrupto das rãs. Bernardo desfiava para o sobrinho, lembranças de suas viagens. O velho Ramiro Ramijo, do Engenho Água de Menina, que guardava correntões num corriboque negro. Correntões enormes - acrescentava. A bela coroa filigranada que uma viúva de Vila Brejão, conhecida por Senhora Senhorinha, conservava no oratório, enfeitando o pescoço de uma Virgem do Amparo sem cabeça. A moça Zezinha Viana, que se desencontrara do noivo e que, depois de vender o enxoval, descrevera com lágrimas nos olhos a inútil coleção de grampos das suas primas doidas de Serinhaém" (OFP, 7980).

E se o rei Alcínoo recebe com encantamento as narrativas de Odisseu, Ascânio sorve deliciado cada palavra advinda dos lábios do tio: 
"Ascânio ouvia-o e mergulhava feliz na paz da noite invernal. Ah! se não tivesse fim aquela hora! Se Bernardo continuasse a falar de ouros e gentes, de caçoletas, anéis de diamantes, compridos trancelins de finagrã, a maioria tocada e olhada uma só vez na vida e em torno dos quais giravam tantos nomes - nomes de famílias ou de pousos -, para sempre lembrados porque se ligavam àqueles esplendores" (OFP, 80).

Bernardo não canta suas histórias, acompanhado de lira ou outro instrumento, mas canta as narrativas, no sentido de transmiti-las, a exemplo de Enéias, que parece agir de igual maneira no banquete do palácio de Dido. Mesmo apenas narrando - sem o embalo musical - o sucesso é grande: se o rei dos feácios reluta em dormir para ter o prazer de ouvir mais narrativas, dizendo que a noite é infinita; se Dido deseja prolongar a narrativa de Enéias até o romper da aurora, o Ascânio brasileiro pensará: "Se não terminassem a paz, a chuva, a evocação das viagens (...)" (OFP, 80).

No "Capítulo sem número, à maneira de remate", Osman Lins arremata (repetindo a expressão) a apropriação do formato epopéico em que a obra que se volta a ela mesma, o canto sobre o próprio canto: após o narrador contar da sociedade de Bernardo com Hutá Vilarim e falar algo das expedições mercantis retomadas, é-nos dito que, numa dessas viagens, Bernardo visitara o antigo funcionário Antônio Chá, agora próspero sitiante, casado e pai de cinco filhos e o antigo empregado aproveitara a ocasião para contar à mulher e filhos a história da guerra entre Bernardo e Nestor. Vejase como o narrador insere o episódio, incluindo a reação de Bernardo à narrativa de Chá:

"De súbito, Bernardo se sentiu modificado, no centro de uma lenda e absurdamente engrandecido: o amarelo, como se ele não estivesse ali presente, pôs-se a contar para a mulher e os cinco filhos a Guerra do Surrão. Acrescentava o número dos cabras, o barracão parecia envolto em chamas, Nestor e o guarda-costas Marvano eram temíveis, porém Bernardo e ele e Ubaldo eram maiores, imensos heróis" (OFP, 314). 
Somos levados, novamente, ao interior de um código interposto em todo o romance - a metalinguagem - a narrativa que fala dela mesma. Afinal, a quais fatos Antônio se refere, que história ele conta, senão a própria narrativa de $O$ fiel e a pedra? Antônio aqui é a representação máxima da voz popular, do cantador nordestino que é inspirado nos aedos da antiga Grécia. Ele conta a história preenchendo cada personagem do estatuto épico que, ao longo dos tempos retornaria nos cavaleiros medievais e nos filmes de faroeste: Nestor e Marvano são os antagonistas, os legítimos vilões; Bernardo, ele e Marvano são os heróis, os mocinhos. E tal é o embelezamento glorioso dos fatos e do caráter dos heróis que Bernardo em pessoa despresentifica-se, não mais tem importância, sendo mesmo ignorado. Como nas epopéias antigas, os fatos reais assumiam proporções grandiosas e detalhes extras iam sendo acrescentados. Um exemplo é o barracão incendiado.

E Bernardo, o tão introvertido Bernardo como reagirá a essa exposição? O esposo de Teresa não se reconhecerá totalmente na narrativa de Chá, mas se perceberá muito mais iluminado. E ele não se incomodará nem um pouco com o exagero do outro; ao contrário - ao romper da aurora [a aurora de dedos róseos de Odisséia, que sempre marca o fim de um ciclo?] - partirá daquele lar, carregando na alma "um pouco do fictício esplendor com que a simplicidade de Antônio o iluminou naquela noite" (OFP, 314). Enfim, Bernardo, tão caracterizado como herói, ainda o será - até mesmo para ele próprio. Bernardo, entre surpreso (racional) e encantado, portanto, se transformará num mito - o material para novas histórias em que ele (ou a personagem) adquirirá os contornos que a oralidade definir. Um círculo, enfim, far-se-á completado: Ascâniocriança fora até a casa de Bernardo e ouvira narrativas advindas das experiências do parente querido; Bernardo dirigira-se até a casa de Antônio Chá e ouvira narrativas de sua própria experiência. Quem nos lembra esses contadores de histórias (Bernardo e 
Antônio Chá)? Talvez Telêmaco no lar de Nestor que lhe narra os feitos de Odisseu? Ou o próprio Odisseu, no palácio de Alcínoo a ouvir Demódoco? Seja qual for a alusão, a capacidade de transmitir valores de que se reveste a literatura está aí posta, novamente. Ascânio aprendia da vida com o tio e Bernardo aprende a se ver de outra maneira, com o simples Antônio.

O fiel e a pedra, pois, revisitando o canto epopéico e popular, soa não como canto simplesmente, mas um alto clangor em que se expressa a alma de um valente, de um explorado, de alguém que não desiste de seus princípios.

No entanto, vale lembrar que embora as epopéias citadas pareçam enaltecer em um primeiro plano um herói, numa análise mais acurada percebe-se que esse indivíduo representa um povo. Sobre o assunto, Lukács admite: "O herói da epopéia, nunca é, a rigor, um indivíduo. Desde sempre se considerou traço essencial da epopéia que seu objeto não é um destino pessoal, mas o de uma comunidade" (LUKÁCS: 2000, 67). Aproximando-se da epopéia tradicional, Osman Lins escreve uma narrativa envolvendo um herói, mas já na "proposição" assinala que esse herói tem ligação intrínseca com um lugar, ele é cidadão de Vitória, logo, tem raízes em uma comunidade e seus feitos não serão pautados pela individualização plena. Por outro lado, sendo O fiel e a pedra uma narrativa advinda da história [houve, efetivamente, latifundiários inescrupulosos e coronéis que menosprezavam as leis] e também da experiência calcada nas relações familiares do autor [o tio Antônio, contando os casos de suas viagens; a tia Laura, doce e discreta segunda mãe; a avó Joana, mulher forte], essa condição corrobora a opinião de Walter Benjamin, de que o narrador veicula os fatos de sua experiência (BENJAMIN: 1994, 198). Encetando um diálogo polifônico com a história, também confirma as observações de Mikhail Bakthin (BAKTHIN: 1998), de que alguns escritores "ouvem" as vozes da história e as expressam em seu texto. Citando os textos 
poéticos, e afirmando a gênese de cunho virgiliano, o romance inscreve-se no que Kristeva denomina intertextualidade. Toda a polifonia, dialogismo, intertextualidade que nitidamente se percebe em $O$ fiel $e$ a pedra contribuem para um melhor entendimento do texto e dos elementos estruturais envolvidos.

Embora tantos outros escritores tenham produzido obras belíssimas, mas nãodialógicas, segundo o preconizado por Bakhtin, Osman Lins faz em O fiel e a pedra o que o estudioso imaginou que Dostoiévski faria em um conto de Tolstoi ${ }^{\text {cxci }}$ : o escritor pernambucano, deliberadamente, transforma seu romance de 1961 em um grande diálogo. E nos grandes diálogos da vida comum, nas grandes discussões em todos os setores não há uma só resposta para os dilemas propostos, nenhuma voz se instaura como a única dotada de verdade, ao contrário, as idéias são postas à mesa e ao final dos debates as dúvidas persistem ou mesmo aumentam, embora uma ou outra tese prevaleça $^{\text {cxcii }}$.

O que mais nos surpreende, entretanto, é que ao preencher o romance com epígrafes de poemas heróicos, Osman Lins está de certo modo, fazendo uma espécie de invocação, uma das partes da epopéia. Usando a capacidade criativa dos grandes poetas do passado, os quais, rogaram às musas que lhes concedessem inspiração, Osman Lins ao mesmo tempo retoma a tradição e lhe rende preitos de louvor ${ }^{\text {cxciii }}$. O cantor ou cantador que abre o livro se remete a Fêmio ou Demódoco, os aedos que inebriavam o público nos banquetes da Odisséia. Incorporadas intimamente ao arcabouço ficcional, as adoções textuais se revelam parte indispensável da narrativa, anunciando o romance e o modelando como um oleiro agregaria o fogo ao barro para dar contorno firme ao pote ideado. Efetivamente, O fiel e a pedra foi proposto como um tributo à arte da palavra. 


\section{BIBLIOGRAFIA}

ADORNO, Theodor W. Notas de literatura. Tradução de Jorge M. B. de Almeida. São Paulo: Duas Cidades/ Editora 34, 2006.

. "Posição do narrador no romance contemporâneo", em BENJAMIM, Walter.

Magia e técnica, arte e política: ensaios sobre literatura e história da cultura. Tradução de Sérgio Paulo Rouanet. 7. ed. São Paulo: Brasiliense, 1994 (Obras escolhidas, v. 1).

AGUIAR E SILVA, Vitor Manuel de. Teoria da literatura. São Paulo: Martins Fontes, 1976.

ALEXANDER, PAT (org.). Enciclopédia ilustrada da Bíblia. Tradução de Edwino A. Roger. São Paulo: Paulinas, 1987.

ALMEIDA, Hugo. (org.) Osman Lins: o sopro na argila. São Paulo: Nanquim, 2004.

$53-5$.

O cárcere Brasil. Cult:Revista Brasileira de Literatura, ano V, julho, 2001, p.

ALTER, Robert, KERMODE, Frank. Guia literário da Bíblia. Tradução de Raul Fiker. São Paulo: Editora da UNESP, 1997.

ANDRADE, Ana Luiza. Osman Lins: crítica e criação. São Paulo: Hucitec, 1987. p. $50-2$.

Entre feitiço e fetiche. Cult:Revista Brasileira de Literatura, ano V, julho, 2001,

_. "Reciclando o engenho: Osman Lins e as constelações de um gesto épico" in ALMEIDA, Hugo (org.). Osman Lins e o sopro na argila. São Paulo: Nankin, 2004

ARIÈS, Philippe, DUBY, Georges (org.). História da vida privada. Tradução de Hildegard Feist. São Paulo: Companhia das Letras, 1990 2v.

ARISTÓTELES. Poética. Porto Alegre: Globo, 1966.

Ars Poetica, 1992.

Poética. Organon. Política. Constituição de Atenas. Tradução da equipe Nova Cultural. São Paulo: Nova Cultural, 1999.

Ética a Nicômaco. Tradução de Pietro Nassetti. São Paulo: Martin Claret, 2007.

HORÁCIO, LONGINO. A poética clássica. Tradução direta do grego e do latim por Jaime Bruna. 12. ed. São Paulo: Cultrix, 2005.

AUERBACH, Erich. Figura. Tradução de Duda Machado. São Paulo: Ática, 1997.

Mimesis: a representação da realidade na literatura ocidental. 4. ed. São Paulo: Perspectiva, 2001.

BAKHTIN, Mikhail. A cultura popular na Idade Média e no Renascimento: o contexto de François Rabelais. Tradução de Yara Frateschi Vieira. São Paulo: Hucitec/ Brasília: Editora da UNESP, 1987. 
. Estética da criação verbal. Tradução de Maria Ermantina Galvão G. Pereira. São Paulo: Martins Fontes, 2000.

. Problemas da poética de Dostoievski. 2. ed. rev. Tradução direta do russo por Paulo Bezerra. Rio de Janeiro: Forense Universitária, 1997.

Questões de literatura e estética: a teoria do romance. 4. ed. Tradução direta do russo por Aurora Fornoni Bernardini, José Pereira Júnior, Augusto Góes Júnior, Helena Spryndis Nazário, Homero Freitas de Andrade. São Paulo: Editora UNESP, 1998.

BARROS, Diana Luz Pessoa de, FIORIN, José Luiz (orgs.). Dialogismo, polifonia, intertextualidade: em torno de Bakhtin. São Paulo: EDUSP, 1994.

BARTHES, Roland. Mitologias. 11. ed. Tradução de Rita Buongermino e Pedro de Souza. Rio de Janeiro: Bertrand Brasil, 2001.

BELLESSORT, André. Virgile: son oeuvre et son temps. Paris: Librairie Académique Perrin Éditeur, 1949.

BENJAMIM, Walter. "O narrador" em Magia e técnica, arte e política: ensaios sobre literatura e história da cultura. Tradução de Sérgio Paulo Rouanet. 7. ed. São Paulo: Brasiliense, 1994 (Obras escolhidas, v. 1).

BERGSON, Henri. Duração e simultaneidade. Tradução de Bento Prado de Almeida Neto. São Paulo: Martins Fontes, 2006

BÍBLIA DE REFERÊNCIA THOMPSON. 6. ed. Tradução de João Ferreira de Almeida. São Paulo: Vida, 1996.

BÍBLIA DO PEREGRINO. São Paulo: Paulus, 2006.

BIEDERMANN, Hans. Dicionário ilustrado dos símbolos. Tradução de Glória Paschoal de Camargo. São Paulo: Melhoramentos, 1993.

BLIKSTEIN, Izidoro. "Intertextualidade e polifonia” em BARROS, Diana Luz Pessoa de, FIORIN, José Luiz (orgs.). Dialogismo, polifonia, intertextualidade: em torno de Bakhtin. São Paulo: EDUSP, 1994.

BOITANI, Piero. A sombra de Ulisses. Tradução de Sara Magelli e Carlo Alberto Dastoli, com poemas transcriados por Haroldo de Campos. São Paulo: Perspectiva, 2005 .

BOOTH, Wayne C. A retórica da ficção. Tradução de Maria Teresa H. Guerreiro. Lisboa: Arcadia, 1980.

BOSI, Alfredo. História concisa da literatura brasileira. 35. ed .São Paulo: Cultrix, 1997.

BRAIT, Beth (org.). Bakhtin: conceitos chaves. 2. ed. São Paulo: Contexto, 2005.

"As vozes bakhtinianas e o diálogo inconcluso" in BARROS, Diana Luz Pessoa de, FIORIN, José Luiz (orgs.). Dialogismo, polifonia, intertextualidade: em torno de Bakhtin. São Paulo: EDUSP, 1994. 
BRANDÃO, Junito. Dicionário mítico-etimológico da mitologia e da religião romana. Petrópolis: Vozes/ EDUNB, 1993.

BROCH, Hermann. A morte de Virgílio. Tradução de Herbert Caro. Rio de Janeiro: Nova Fronteira, 1982.

BRUNEL, Pierre (org.). Dicionário de mitos literários. Tradução de Carlos Susseking, Jorge Laclette, Maria Thereza Resende Costa, Vera Whately. Rio de Janeiro: José Olympio, 1997.

BUCKLAND, A. R. Dicionário Bíblico Universal. 2. ed. Tradução de Joaquim dos Santos Figueiredo. Rio de Janeiro: Livros evangélicos, 1957.

CAIMI, Claudia. A representação dialógica do discurso em A rainha dos cárceres da Grécia, de Osman Lins. Revista Estudos de Literatura Brasileira Contemporânea. Brasília, n. 15, set/out. 2001, p.3-16.

. "Representação e autoritarismo em A Rainha dos Cárceres da Grécia" in ALMEIDA, Hugo (org.). Osman Lins e o sopro na argila. São Paulo: Nankin, 2004.

CAMÕES. Os lusíadas. São Paulo: Jackson, 1956, (Clássicos Jackson, v. VII).

[s.d.].

. (obra comentada por Othoniel Motta). 4. ed. São Paulo: Melhoramentos,

CAMPOS, Haroldo de. A arte no horizonte do improvável - e outros ensaios. 4. ed. São Paulo: Perspectiva, 1977.

Ilíada de Homero. (tradução bilíngüe por Haroldo de Campos) 2. Ed. São Paulo: Mandarim, 2002, v. I.

Ilíada de Homero. (tradução bilíngüe por Haroldo de Campos) 2. ed. São Paulo: Arx, 2002, v. II.

CANDIDO, Antonio. Formação da literatura brasileira: momentos decisivos. São Paulo: Martins, 19592 v.

Literatura e sociedade: estudos de teoria e história literária. 8. ed. São Paulo: T. A. Queiroz, 2000.

. Na sala de aula: cadernos de análise literária. 6. ed. São Paulo: Ática, 1998.

. O estudo analítico do poema. 4. Ed. São Paulo: Humanitas, 2004.

. O método crítico de Sílvio Romero. São Paulo: Edusp, 1988.

. Tese e antítese: ensaios. 4. ed. São Paulo: T. A. Queiroz, 2002.

, CASTELlO, José Aderaldo. Presença da literatura brasileira. Modernismo. 7. ed. São Paulo/ Rio de Janeiro: Difel, 1979.

, ROSENFELD, Anatol, PRADO, Décio de Almeida, GOMES, Paulo E. S. A personagem de ficção. 2. ed. São Paulo: Perspectiva, 1970.

CARCOPINO, Jérôme. Virgile et les origines d'ostie. Paris: Presses Unversitaires de France. 1968. 
CARPEAUX, Otto Maria. História da Literatura Ocidental. 2. ed. Rio de Janeiro: Alhambra, 1978. v. 1.

CARVALHAL, Tânia Franco (org.). Culturas, contextos e discursos: limiares críticos no comparativismo. Porto Alegre: Editora da UFRGS, 1999.

CESAR, Guilhermino. O obstinado Osman Lins. Correio do Povo, Porto Alegre, 30 set. 1978, Caderno de Sábado, p.3.

CHKLOVSKI, Vitor e outros. Teoria da literatura: formalistas russos. Tradução de Ana Maria Ribeiro, Maria Aparecida Pereira, Regina L. Zilbermann, Antônio Carlos Hohlfeldt. Porto Alegre: Globo, 1971.

CLARK, Katerina, HOLQUIST, Michael. Mikhail Bakhtin. Tradução de J. Guinsburg. São Paulo: Perspectiva, 1998.

COELHO, Nelly Novaes. "O Fiel e a Pedra" em ___. O ensino da literatura sugestões metodológicas para o curso secundário e normal. São Paulo: FTD, 1966, p. 435-47.

COHEN, Jean. Estrutura da linguagem poética. 2. ed. Tradução de Álvaro Lorencini e Anne Arnichand. São Paulo: Cultrix, 1998.

COLlingWOOD, R.G. A ideia de História. Tradução de Alberto Freire. Lisboa: Editorial Presença, 1972.

COSTA, Camille Vieira da. Dicionário de nomes próprios. São Paulo: Traço, 1988.

COTERRELL, Arthur. Dicionário de mitologia universal. Tradução de Vicente Villacampa. Barcelona: Ariel, 1988.

COUTINHO, Afrânio. Introdução à literatura no Brasil. 16. ed. Rio de Janeiro: Bertrand Brasil, 1995.

CUNHA, Antonio Geraldo da. Dicionário etimológico da língua portuguesa. 2. ed. Rio de Janeiro: Nova Fronteira, 1986.

CURTIUS, Ernest Robert. Literatura européia e Idade Média latina. Tradução Teodoro Cabral e Paulo Rónai. São Paulo: Hucitec: Edusp, 1996.

D'ONOFRIO, Salvatore. Da Odisséia ao Ulisses: evolução do gênero narrativo. São Paulo: Duas Cidades, 1981.

. Teoria do texto 1: prolegômenos e teoria da narrativa. São Paulo: Ática, 1995.

DALCASTAGNÈ, Regina. A garganta das coisas: movimentos de Avalovara, de Osman Lins. Brasília: Editora da Universidade de Brasília/ São Paulo: Imprensa Oficial do Estado, 2000.

DEL PRIORE, Mary (org.), BASSANEZI, Carla (coord.). História das mulheres no Brasil. 2. ed. São Paulo: Contexto/ Editora da UNESP, 1997.

DIAS, Maria Teresa de Jesus. "Osman Lins dramaturgo: no caminho para a história" in ALMEIDA, Hugo (org.). Osman Lins e o sopro na argila. São Paulo: Nankin, 2004. 

$56-9$.

Fortuna crítica. Cult: Revista Brasileira de Literatura, ano V, julho, 2001, p.

DODDS, E. R. Os gregos e o irracional. Tradução de Paulo Domenech Oneto. São Paulo: Escuta, 2002.

DOURADO, Autran. Rigor e paixão. Correio do Povo, Porto Alegre, 30 set. 1978, Caderno de Sábado, p. 7.

DUROZOI, Gérard, ROUSSEL, André. Dicionário de filosofia. Tradução de Marina Appenzeller. Campinas: Papirus, 1993.

EAGLETON, Terry. Teoria da literatura: uma introdução. Tradução de Waltensir Dutra. São Paulo: Martins Fontes, 2001.

ELIADE, Mircea. Mito e realidade. 5. ed. Tradução de Pola Civelli. São Paulo: Perspectiva, 2000.

FALCI, Miridan Knox. "Mulheres do sertão nordestino", em DEL PRIORE, MARY (org.), BASSANEZI, Carla (coord.). História das mulheres no Brasil. 2. ed. São Paulo: Contexto/ Editora da UNESP, 1997.

FÁVERO, Leonor Lopes. "Paródia e dialogismo" em BARROS, Diana Luz Pessoa de, FERREIRA, Ermelinda. Cabeças compostas: a personagem feminina na narrativa de Osman Lins. Rio de Janeiro: O Autor, 2000.

. "A dama e o unicórnio: exercícios de imaginação" in ALMEIDA, Hugo (org.). Osman Lins e o sopro na argila. São Paulo: Nankin, 2004.

- O retrato perdido na origem da criação da personagem osmaniana. Revista Estudos de Literatura Brasileira Contemporânea. Brasília, n. 15, set/out. 2001, p. 3-16.

(org.). Vitral ao sol: ensaios sobre a obra de Osman Lins. Recife: Editora Universitária da UFPE, 2004.

FIGUEIREDO, Fidelino de. Literatura portuguesa: desenvolvimento histórico das origens à atualidade. 3. ed. Rio de Janeiro: Livraria Acadêmica, 1955.

FINLEY, Moses I. O mundo de Ulisses. 3. ed. Lisboa: Presença, 1988.

(org.) O legado da Grécia: uma nova avaliação. Tradução de Yvette Vieira Pinto de Almeida. Brasília: Editora da UNB, 1998.

FIOL, E. Valentí. Antologia de prosistas latinos. 4. ed. Barcelona: Bosch Casa Editorial, 1952.

FIORE. Tommaso. La poesia di Virgilio. 2. ed. rev. e corr. Bari: Gius. Laterza \& Figli, 1946.

FIORIN, José Luiz (orgs.). Dialogismo, polifonia, intertextualidade: em torno de Bakhtin. São Paulo: EDUSP, 1994.

FORSTER, Edward M. Aspectos do romance. 2. ed. Tradução de Maria Helena Martins, São Paulo: Globo, 1998. 
FRANCISCATO, Maria Cristina Rodrigues da Silva. 'Tau' 'úpsilon' 'qui' 'eta' e caráter no Hipólito de Eurípides. São Paulo, 2006, 308 p. Tese (Doutorado). Faculdade de Letras, Departamento de Letras Clássicas e Vernáculas da Faculdade de Filosofia, Letras e Ciências Humanas. Universidade de São Paulo.

FRANK, Joseph. Pelo prisma russo: ensaios sobre literatura e cultura. Tradução de Paula Cox Rolim e Francisco Achcar, São Paulo: EDUSP, 1992.

FRIEDMAN, Norman. The theory of the novel. Nova York: Free Press, 1967.

FRYE, Northrop. Anatomia da crítica. Tradução de Péricles Eugênio da Silva Ramos. São Paulo: Cultrix, 1973.

- O código dos códigos: a Bíblia e a literatura. Tradução de Flávio Aguiar. São Paulo: Boitempo, 2004.

GENETTE, Gerard. Figuras. São Paulo: Perspectiva, 1972.

. Figures II. Paris: Seuil, 1969.

Figures III. Paris: Seuil, 1972.

Frontières du récit. Communications, 8, p. 152-63, Paris, 1966.

Introduction à l'architexte. Paris, Seuil, 1979.

. Palimpsestes. Paris: Seuil, 1982.

Noveau discours du récit. Paris: Seuil, 1983.

GIARDINA, Andrea (org). O homem romano. Tradução Maria Jorge Vilar de Figueiredo. Lisboa: Editorial Presença, 1992.

GRIMAL, Pierre. Dicionário da mitologia grega e romana. 4. ed. Tradução de Victor Jabouille. Rio de Janeiro: Bertrand Brasil, 2000.

- Virgílio ou o segundo nascimento de Roma. Tradução de Ivone Castilho Benedetti. São Paulo: Martins Fontes, 1992.

HAMBURGER, Käte. A lógica da criação literária. 2. ed. Tradução de Margot P. Malnic. São Paulo: Perspectiva, 1975.

HEGEL, Friedrich. Estética. Lisboa: Guimarães, 1964.

Curso de estética: o belo nas artes. Tradução de orlando Vitorino. São Paulo: Martins Fontes, 1996.

Curso de estética: o sistema das artes. Tradução de Álvaro Ribeiro. São Paulo: Martins Fontes, 1997.

. Cursos de estética. Tradução de Marco Aurélio Werle, Oliver Tolle. Consultoria de Victor Knoll. São Paulo: EDUSP, 2004, v. IV.

HOLANDA, Lourival. "Osman Lins: resistência e rigor" in FERREIRA, Ermelinda (org.). Vitral ao sol: ensaios sobre a obra de Osman Lins. Recife: Editora Universitária da UFPE, 2004. 
HOMERO. A Ilíada. Tradução de Manuel Odorico Mendes. Prefácio de Silveira Bueno. São Paulo: Atena, 1956 (Biblioteca Clássica, v. XXXVII, nova edição). 1960 .

Odisséia. Tradução de Carlos Alberto Nunes. 3. ed. São Paulo: Melhoramentos, . Tradução de Carlos Alberto Nunes. Rio de Janeiro: Editora Três, 1974. v. 11 (Biblioteca Universal).

$\overline{2002 .}$ • — T Tradução de Antonio Pinto de Carvalho. São Paulo: Nova Cultural, __ _ _ Tradução de Manuel Odorico Mendes. São Paulo: Martin Claret, 2007.

HOUAISS, Antonio, VILLAR, Mauro de Salles. Dicionário Houaiss da língua portuguesa. Rio de Janeiro: Objetiva, 2001.

HUIZINGA, Johan. Homo ludens: o jogo como elemento da cultura. 4. ed.Tradução de João Paulo Monteiro. São Paulo: Perspectiva, 1996.

HUIZMAN, Denis, VERGEZ, Andre. História dos filósofos ilustrada pelos textos. 5. ed. Tradução do francês por Lélia de Almeida Gonzalez. Rio de Janeiro: Freitas Bastos, 1982.

IGEL, Regina. Osman Lins: uma biografia literária. São Paulo: T. A. Queiroz/ Brasília: INL, 1988.

JAKOBSON, Roman. Poética em ação. (Org. João Alexandre Barbosa) São Paulo: Perspectiva/ EDUSP, 1990.

JOLLES, André. Forma simples. Tradução de Álvaro Cabral. São Paulo: Cultrix, 1976.

KANT, Immanuel. A paz perpétua e outros opúsculos. Tradução de Artur Morão. Lisboa: Edições 70, 2004.

Antropologia de um ponto de vista pragmático. Tradução de Clélia Aparecida Martins. Revisão técnica Márcio Suzuki e colaboração de Vinícius de Figueiredo. São Paulo: Iluminuras, 2006.

Crítica da razão prática. Tradução de Paulo Barrera. Revisão da tradução de Saulo Krieger. São Paulo: Ícone, 2005.

Crítica da razão pura. Tradução de Lucimar A. Coghi Anselmi e Fulvio Lubisco. São Paulo: Ícone, 2007.

Crítica da faculdade do juízo. 2. Ed. Tradução de Valerio Rohden e António Marques. Rio de Janeiro: Forense Universitária, 2008.

. Fundamentação da metafísica dos costumes. Tradução do alemão por Paulo Quintela. Lisboa, 2007.

Metafísica dos costumes. Parte II. Princípios metafísicos da doutrina e da virtude. Tradução de Artur Morão. Lisboa: Edições 70, 2004.

KAYSER, Wolfgang. Análise e interpretação da obra literária: introdução à ciência da literatura. 7. ed. rev.. Tradução de Paulo Quintela. Coimbra: Arménio Amado, 1985. 
KIRSH, Gaby. "Recepção da obra de Osman Lins pela crítica de língua francesa e alemã" in ALMEIDA, Hugo (org.). Osman Lins e o sopro na argila. São Paulo: Nankin, 2004.

KOHN, Ana Luisa Kaminski. "O bicho-palavra produzindo fissuras" in ALMEIDA, Hugo (org.). Osman Lins e o sopro na argila. São Paulo: Nankin, 2004.

KRISTEVA, Julia. Introdução à semanálise. 2. ed. Tradução de Lucia Helena França Ferraz. São Paulo: Perspectiva, 2005.

LADEIRA, Julieta de Godoy. Ele foi "Beau Geste" até morrer. Correio do Povo, Porto Alegre, 30 set. 1978, Caderno de Sábado, p. 5.

LALANDE, André. Vocabulário técnico e crítico da filosofia. 3. ed. Tradução de Fátima Sá Correia, Maria Emília V. Aguiar, José Eduardo Torres, Maria Gorete de Souza. São Paulo, Martins Fontes, 1999.

LAMAISON, Didier. Dicionário de provérbios: francês, português, inglês. 2. ed. rev. e ampl. Tradução de Roberto Cortes de Lacerda, Helena da Rosa Cortes de Lacerda, Estela dos Santos Abreu. São Paulo: Editora UNESP, 2004.

LE GOFF, Jacques (org). A história nova. 4. ed. Tradução de Eduardo Brandão. São Paulo: Martins Fontes, 1998.

História e memória. Tradução de Suzana Ferreira Borges, Bernardo Leitão e Irene Ferreira. 4. ed. Campinas: Editora da UNICAMP, 1996.

Le petit Robert 2: dictionaire universel de noms propres. Paris: Le Robert, 1993.

LIMA, Luiz Costa. Dispersa demanda: ensaios sobre literatura e teoria. Rio de Janeiro: Francisco Alves, 1981.

História. Ficção. Literatura. São Paulo: Companhia das Letras, 2006. Intervenções. São Paulo: EDUSP, 2002.

Terra, 2003. Mímesis e modernidade: formas das sombras. 2. ed. atual.São Paulo: Paz e . O redemoinho do horror: as margens do Ocidente. São Paulo: Planeta, 2003.

LINS, Ângela. "O homem que escrevia livros de fogo"in FERREIRA, Ermelinda (org.). Vitral ao sol: ensaios sobre a obra de Osman Lins. Recife: Editora Universitária da UFPE, 2004

LINS, Letícia. "Quando o escritor é pai" in FERREIRA, Ermelinda (org.). Vitral ao sol: ensaios sobre a obra de Osman Lins. Recife: Editora Universitária da UFPE, 2004.

LINS, Litânia. "Fazia questão que não perdêssemos o sonho" in FERREIRA, Ermelinda (org.). Vitral ao sol: ensaios sobre a obra de Osman Lins. Recife: Editora Universitária da UFPE, 2004.

LINS, Osman. A rainha dos cárceres da Grécia. 2. ed. São Paulo: Melhoramentos, 1977.

Avalovara. 2. ed. São Paulo: Melhoramentos, 1974. 
. Casos especiais de Osman Lins. São Paulo: Summus, 1978.

1977. Do ideal e da glória: problemas inculturais brasileiros. São Paulo: Summus,

Evangelho na taba: outros problemas inculturais brasileiros. São Paulo: Summus, 1979.

Guerra sem testemunhas: o escritor, sua condição e a realidade social. São Paulo: Ática, 1974.

. Lima Barreto e o espaço romanesco. São Paulo: Ática, 1976.

. Lisbela e o prisioneiro: comédia em três atos. São Paulo: Scipione, 1994.

. Marinheiro de primeira viagem. 2. ed. São Paulo: Summus, 1980.

. O diabo na noite de Natal. São Paulo: Pioneira, 1977.

. O fiel e a pedra. 3. ed. São Paulo: Martins, 1971.

. O visitante. 2. ed. São Paulo: Martins, 1970.

. Os gestos. 3. ed. São Paulo: Moderna, 1994.

1977.

. (org.) Missa do Galo: variações sobre o mesmo tema. São Paulo: Summus,

. Nove, novena. 2. ed. São Paulo: Melhoramentos, 1975.

. Santa, Automóvel e Soldado. São Paulo: Duas Cidades, 1975.

. Um mundo estagnado. Recife: Imprensa Universitária, 1966.

, LADEIRA, Julieta de Godoy. La Paz existe? São Paulo: Summus, 1977

. Melhores contos de Osman Lins. (Seleção e prefácio de Sandra Nitrini). São

Paulo: Global, 2003.

LÍVIO, Tito. História de Roma. Tradução de Paulo Matos Peixoto. São Paulo: Paumape, 1989, v. I.

LOPES, Edward. "Discurso literário e dialogismo em Bakhtin" em BARROS, Diana Luz Pessoa de, FIORIN, José Luiz (orgs.). Dialogismo, polifonia, intertextualidade: em torno de Bakhtin. São Paulo: EDUSP, 1994.

LUCAS, Fábio. "A face visível: crítica. Rio de Janeiro: José Olympio/Conselho Estadual de Cultura, SECET-SP, 1973, p. 82, 112, 115-25.

O caráter social da literatura brasileira. 2. ed. São Paulo: Quíron, 1976.

LUKÁCS, Georg. A teoria do romance: um ensaio histórico-filosófico sobre as formas da grande épica. Tradução de José Marcos Mariani de Machado. São Paulo, 2000.

MACHADO, Irene A. O romance e a voz: a prosaica dialógica de Mikhail Bakhtin. Rio de Janeiro: Imago/ FAPESP, 1995. 
MACHADO, José Pedro. Dicionário etimológico da língua portuguesa. 2. ed. Lisboa: Confluência/ Horizonte, 1967.

MAINGUENEAU, Dominique. O contexto da obra literária: enunciação, escritor, sociedade. 2. ed. Tradução de Marina Appenzeller. São Paulo: Martins Fontes, 2001.

MENDES, João Pedro. Construção e arte das Bucólicas de Virgílio. Brasília: UnB/ INL, 1985.

MERLEAU-PONTY, Maurice. O olho e o espírito. Tradução de Paulo Neves e Maria Ermantina Galvão Gomes Pereira. São Paulo: Cosac \& Naify, 2004.

MIRAPALHETE, Daliana Amaral. A inspiração épica em O fiel e a pedra, de Osman Lins; etapas de uma confecção. Porto Alegre, 2000. 121 p. Dissertação (Mestrado). Instituto de Letras. Universidade Federal do Rio Grande do Sul.

MOISÉS, Massaud. A literatura brasileira através dos textos. 14. ed. São Paulo: Cultrix, 1989.

. O artesão literário. O Estado de S. Paulo. São Paulo, 2 jul, 1988, Caderno de Cultura, p. 1-3.

NAZARIO, Helena. A filha do capitão e o jogo das epígrafes. São Paulo: Perspectiva, 1981.

NITRINI, Sandra. Literatura comparada: história, teoria e crítica. 2. ed. São Paulo: EDUSP, 2000.

- "O tempo na arte, a arte no tempo (uma leitura de Marinheiro de Primeira Viagem)" in ALMEIDA, Hugo (org.). Osman Lins e o sopro na argila. São Paulo: Nankin, 2004. 46-9.

Poética de tensões. Cult:Revista Brasileira de Literatura, ano V, julho, 2001, p.

Poéticas em confronto: Nove, novena e o novo romance. São Paulo: Hucitec / Brasília: INL/ Fundação Pró-Memória, 1987.

. "Um singular contador de estórias" in LINS, Osman. Melhores contos (seleção de Sandra Nitrini). São Paulo: Global, 2003.

. "Viagem e projeto literário (Osman Lins na França)" em (org.). Aquém e além mar - relações culturais: Brasil e França. São Paulo: Hucitec, 2000, p. 210-29.

NUNES, Benedito. O tempo na narrativa. 2. ed. São Paulo: Ática, 1995.

OEHLER, Dolf. Terrenos vulcânicos. Tradução de Samuel Titan Jr., Márcio Suzuki, Luís Repa, José Bento Ferreira.

OLIVEIRA, Franklin. A semana de arte moderna na contramão da história e outros ensaios. Rio de Janeiro: Topbooks, 1993.

Viola d'amore. Rio de Janeiro: Edições do Val, 1965. 
OLIVEIRA, Lauro de. "Osman Lins: do caos ao cosmo" in FERREIRA, Ermelinda (org.). Vitral ao sol: ensaios sobre a obra de Osman Lins. Recife: Editora Universitária da UFPE, 2004.

—. "Osman Lins: ética na vida e na ficção" in ALMEIDA, Hugo (org.). Osman Lins e o sopro na argila. São Paulo: Nankin, 2004.

OTTO, Walter Friedrich. Os deuses da Grécia. Tradução de Ordep Trindade Serra. São Paulo: Odysseus, 2005.

PAES, José Paulo. "O mundo sem aspas" in ALMEIDA, Hugo (org.). Osman Lins e o sopro na argila. São Paulo: Nankin, 2004.

- Teofania: o espírito da religião dos gregos antigos. Tradução de Ordep Trindade Serra. São Paulo: Odysseus, 2006.

PARATORE, Ettore. História da literatura latina. Tradução Manuel Losa. Lisboa: Fundação Calouste Gulbenkian, 1983.

. Virgilio. 2. ed.rev. e corr. Firenze (Itália): Sansoni, 1954.

PAZ, Octavio. Signos em rotação. 3. ed. São Paulo: Perspectiva, 2003.

PEREIRA, Isidro S. J. Dicionário greco-português e português-grego. 8. ed. Braga: Apostolado da Imprensa, 1998.

PEREIRA, Maria Helena da Rocha. Estudos de história da cultura clássica. 3 ed. Lisboa: Fundação Calouste Gulbenkian, 2002.

PERRONE-MOISÉS, Leyla. Falência da crítica - um caso limite: Lautréamont. São Paulo: Perspectiva, 1973.

. "Quando Osman Lins preparava suas armas" em ___. Inútil poesia e outros ensaios breves. São Paulo: Companhia das Letras, 2000, p. 230-3.

PERROT, Michelle. Mulheres públicas. Tradução de Roberto Leal Ferreira. São Paulo: Editora da UNESP, 1998.

PLATÃO. Apologia de Sócrates-Banquete. Tradução de Jean Melville. São Paulo: Martin Claret, 2007.

. A República. Tradução de Pietro Nassetti. São Paulo: Martin Claret, 2007.

PONTES, Joel. "Os contrastes no conto de Osman Lins" em . O aprendiz de crítica (1955-1959). Rio de Janeiro: MEC/ INL, 1960, p. 85-93.

PORTELLA, Eduardo. "Dois acentos rítmicos do conto" em . Dimensões II: crítica literária. Rio de Janeiro: Agir, 1959, p. 125-37.

. Teoria da comunicação literária. Rio de Janeiro: Tempo Brasileiro, 1970.

POUND, Ezra. ABC da literatura. 8. ed. Tradução de Augusto de Campos e José Paulo Paes. São Paulo: Cultrix, 1998.

REYS, Graciela. Polifonía textual: la citación en el relato literario. Madrid: Editorial Gredos, 1984. 
ROSENFELD, Anatol. Letras e leituras. São Paulo: Perspectiva/ EDUSP; Campinas: Editora da UNESP, 1994.

. O teatro épico. 4. ed. São Paulo: Perspectiva, 2002.

. Texto/ contexto I. 5. ed. São Paulo; Perspectiva, 1996.

1993. . II. São Paulo: Perspectiva/ Edusp; Campinas: Editora da UNICAMP,

RUSSELL, Bertrand. História da filosofia ocidental. Tradução de Breno Silveira. São Paulo; Companhia Editora Nacional, 1957.

SAMOYAULT, Tiphaine. L'intertextualité. Memoire de la littérature. Paris: Puf, 1997.

SANT'ANNA, Affonso Romano de. Paródia, paráfrase \& cia. 5. ed. São Paulo: Ática, 1995.

SARAIVA, António José, LOPES, Oscar. História da literatura portuguesa. 11. ed. Porto: Porto Editorial, 1955.

SCHNAIDERMAN, Boris (org.). Semiótica russa. Tradução de Aurora Fornoni, Boris Schnaiderman e Lucy Seki. São Paulo: Perspectiva, 1979.

SCHÜLER, Donaldo. Aspectos estruturais na Ilíada. Porto Alegre: Editora da UFRGS, 1972.

A construção da Ilíada. Porto Alegre: LPM, 2004.

. Eros: dialética e retórica. São Paulo: Edusp, 1992.

Teoria do romance. São Paulo: Ática, 1989.

SIMONS, Marisa. As falas do silêncio em 'O fiel e a pedra' de Osman Lins. São Paulo: Humanitas, 1999.

. "Pentágono de Hahn': O enigma geométrico de Osman Lins" in ALMEIDA, Hugo (org.). Osman Lins e o sopro na argila. São Paulo: Nankin, 2004.

SNELL, Bruno. A cultura grega e as origens do pensamento europeu. Tradução de Pérola de Carvalho. São Paulo: Perspectiva, 2005.

SOARES, Marisa Balthasar. No arquivo do artesão. Cult:Revista Brasileira de Literatura, ano V, julho, 2001, p. 62-3.

. “ 'Retábulo de Santa Joana Carolina', o palco na palavra in ALMEIDA, Hugo (org.). Osman Lins e o sopro na argila. São Paulo: Nankin, 2004.

SPALDING, Tassilo Orpheu. Dicionário de mitologia grego-latina. Belo Horizonte: Editora Itatiaia, 1965.

STEINER, George. A morte da tragédia. Tradução de Isa Kopelman. São Paulo: Perspectiva, 2006.

SZONDI, Peter. Teoria do drama moderno [1880-1950]. Tradução de Luiz Sérgio Repa. São Paulo: Cosac \&Naify, 2001. 
TAVARES, Hênio. Teoria literária. 8. ed. Belo Horizonte: Editora Itatiaia, 1984.

TINIANOV, Iuri. O problema da linguagem poética I. Tradução de Maria José Azevedo Pereira e Caterina Barone. Rio de Janeiro: Tempo Brasileiro, 1975.

O problema da linguagem poética II. Tradução de Maria José Azevedo Pereira e Caterina Barone. Rio de Janeiro: Tempo Brasileiro, 1975.

"Da evolução literária” em ___ e outros. Teoria da literatura: formalistas russos. Tradução de Ana Maria Ribeiro, Maria Aparecida Pereira, Regina L. Zilbermann, Antônio Carlos Hohlfeldt. Porto Alegre: Globo, 1971.

THOMAS, Rosalind. Letramento e oralidade na Grécia antiga. Tradução de Raul Fiker. São Paulo: Odysseus, 2005.

TODOROV, Tzvetan. Estruturalismo e poética. 4. ed. rev. e atualiz. Tradução de José Paulo Paes e Frederico Pessoa de Barros. São Paulo: Cultrix, 1976.

. Os gêneros do discurso. Tradução de Elisa Angotti Kossovitch. São Paulo: Martins Fontes, 1980.

Poética. Tradução de António José Massano. Lisboa: Teorema, 1973.

. Poética da prosa. Tradução de Maria de Santa Cruz. Lisboa: Edições 70, 1969.

VASCONCELLOS. Paulo Sérgio de. Efeitos intertextuais na Eneida de Virgílio. São Paulo: Humanitas / FFLCH/USP: FAPESP, 2001.

VERNANT, Jean-Pierre. As origens do pensamento grego. 13. ed. Tradução de Ísis Borges B. da Fonseca. Rio de Janeiro: Difel, 2003.

. Mito \& pensamento entre os gregos: estudos de psicologia histórica. 2. ed. rev. Tradução de Haiganuch Sarian. Rio de Janeiro: Paz e Terra, 1990.

, VIDAL-NAQUET, Pierre. Mito e tragédia na Grécia antiga. Tradução de Anna Lia A. de Almeida Prado, Filomena Yoshie Hirata Garcia, Maria da Conceição M. Cavalcante, Bertha Halpem Gurovitz e Hélio Gurovitz. São Paulo: Perspectiva, 2005.

VIDAL-NAQUET, Pierre. Os gregos, os historiadores, a democracia: o grande desvio. Tradução de João Batista Neto. São Paulo: Companhia das Letras, 2002.

VIEIRA, Antonio. Sermões. 6. ed. Rio de Janeiro: Agir, 1972.

I e II.

. Organização de Alcir Pécora. 3. reimpr. São Paulo: Hedra, 2001. Tomos

VIRGÍlLIO. A Eneida. Tradução de Odorico Mendes. São Paulo: Atena, 1942, Estudo introdutivo de G. D. Leoni.

As Geórgicas. Tradução de Antonio Feliciano de Castilho. Anotações de Othoniel Motta. São Paulo: Heros, 1930.

- Geórgicas/ Eneida. Tradução de António Feliciano de Castilho e Manuel Odorico Mendes. São Paulo: Jackson, 1949, (Clássicos Jackson, v. III). 
. Tradução de José Victorino Barreto Feio e José Maria da Costa e Silva. Edição organizada por Paulo Sérgio de Vasconcellos. São Paulo: Martins Fontes, 2004. WELLEK, René, WARREN, Austin. Teoria da literatura. Tradução de José Palla e Carmo. Lisboa: Publicações Europa-América, 1962.

ZILBERMANN, Regina. Processos técnicos e cosmovisão. Correio do Povo, Porto Alegre, 30 set. 1978, Caderno de Sábado, p. 11.

\begin{abstract}
'Diz o autor que retirou esse fragmento do "Cancioneiro popular" (OFP, citações iniciais).
ii Sobre as epígrafes, dentre várias ponderações, agrada-nos as considerações de dois autores, especialmente. Franklin de Oliveira, no livro Viola d'Amore, especialmente no capítulo em que analisa Guimarães Rosa, diz: "Em geral a epígrafe é um artifício inócuo, ou porque represente simples excrescência, reles enfeite, ou porque revele exibição vaidosa, ou ainda porque mostre desejo de apadrinhamento, vontade de amparo de um nome ilustre. Algumas vezes equivale a honrada confissão de influência - indicação de fonte. Com os românticos converteu-se em verdadeiro tic. Walter Scott costumava, em todos os seus romances, epigrafar cada capítulo com alguns versos de poetas ingleses ou simples canções escocesas. Esta é, provavelmente, a origem do 'Iuxo epigráfico' de todos os românticos, inclusive dos brasileiros. Os leitores estavam tão habituados a ver epígrafes encimando capítulos - na maioria das vezes versos que só de maneira puramente externa coincidiam com a ação novelística - que deixaram de prestar atenção aos casos de relação profunda. (...) Em Sagarana tudo está magistralmente ordenado, disposto para bem funcionar, desde o simples grafismo às partes que representam, no contexto, o tecido conjuntivo, as dobras de passagem, as pontes entre uma situação e outra, um episódio e outro. (...) Em livro de tal forma elaborado, as epígrafes teriam também de ser dinâmicas. Elas são uma espécie de formulação algébrica das histórias, siglas em arquitrave, clave e cimalha das histórias. Acusam o que vai vir; condensam a dimensão metafísica. São inscrições que encerram o tema (...). As epígrafes descobrem ou indicam o ideário do autor astuciosamente oculto na trama da narrativa" (OLIVEIRA: 1965). Helena Nazário, analisando um conto de Puschkin, em seu livro A Filha do Capitão e o jogo das epígrafes, diz que as epígrafes, "à maneira de batedores" que "introduzem todas as seqüências do discurso" (NAZARIO: 1981, p. 137). A autora diz ainda: "O jogo das epígrafes revela-se, portanto, como um recurso formal muito eficaz, na medida em que a alusão aos autores ou obras literárias e às formas da criação popular aponta para determinados estilos, instituindo, a partir daí, o conflito de duas influências artísticas distintas" (idem, ibidem, p. 138).
\end{abstract}

iii Não pretendemos fazer estudo exaustivo da fortuna crítica de 0 fiel e a pedra, pois esse não foi o objetivo máximo de nossas reflexões, uma vez que os levantamentos efetuados brilhantemente por Regina Igel e Ana Luiza Andrade dão conta desse viés, informando, também, a biobibliografia do autor (conferir em IGEL: 1988 e ANDRADE: 1987); todavia, registramos aqui, alguns comentários interessantes sobre 0 fiel e a pedra. Guilhermino César diz: "O fiel e a pedra deu-me um soco na cara. Não tenho outra expressão. É um romance sólido, e por sua causa voltei à estante para reexaminar os escritos da primeira fase do amigo pernambucano. E aí, com mais calma, fui encontrar um temperamento que me revelou, antes de tudo, um 'represado' em busca de exteriorização. Caso raro numa literatura espalhafatosa de cores brilhantes, o mundo imaginário de Osman Lins se reduz a um solilóquio" (CESAR, Guilhermino. O obstinado Osman Lins. Correio do Povo. Porto Alegre, 30 de setembro de 1978, Caderno de Sábado, p. 3). Massaud M oisés diz: "Romance denso, maduro, resistiu ao vendaval demolidor do novo-romance francês e à erosão do tempo e das novidades embriagantes; passados cerca de treze anos do seu lançamento, creio ainda procedente o juízo que externei em artigo de abril de 1962: tudo indica que temos em mãos um romance capaz de ficar e mesmo marcar a ficção brasileira dos últimos dez anos" (MOISÉS, Massaud. "O fiel e a pedra, hoje" in LINS, Osman. 0 fiel e a pedra. 6. ed. São Paulo: Summus, 1979, prefácio).

iv Em artigo para o Jornal do Commercio, Rio de Janeiro, 1 de outubro de 1961, o crítico literário Adonias Filho atribui a Antônio Chá uma relevância especial. 0 autor diz que o romance está todo estruturado 
em torno dessa personagem. Acrescenta que, não fosse Bernardo, a pedra, o romance seria dele, do Amarelinho, que se impõe como "personalidade regional" e de "raízes folclóricas" remetendo ao teatro de Ariano Suassuna ou a narrativa oral cujo protagonista é Malazartes (conferir em IGEL: 1988, P. 61, nota 24). Regina Igel discorda dessa relevância e nós ratificamos tal posição.

${ }^{\vee}$ Em Marinheiro de primeira viagem, livro gestado da primeira viagem à França, no ano de 1961, Osman Lins entrelaça literalmente seu romance 0 fiel e a pedra à Eneida de Virgílio, colocando-se, inclusive, na pele de Ascânio, sua personagem. Leiamos, na íntegra, o que o autor informa desse texto oriundo de sua pena: "Entregue, desde ontem, à revisão de 0 fiel e a pedra, essa tentativa de transposição, para 0 Nordeste de 1936, da Eneida. Não propriamente uma transposição, uma vez que muitos dos personagens e fatos apresentados têm origem na minha experiência. Mas a verdade é que o romance, já iniciado, foi replanejado tendo em vista o poema de Virgílio. Daí o tom algumas vezes descritivo do livro. (...) Ascânio angustia-se com o desaparecimento de seus mitos. Ele vê, em todas as coisas amáveis, uma garra escondida, um dente a corroê-las. Embora não possa dizer, desse personagem, que seja autobiográfico, a verdade é que, em certa época, perturbava-me esse fugir das coisas entre as minhas mãos. Principalmente o fim irremediável de tudo o que constituiu o mundo de minha infância, que absolutamente não foi risonha, nem festiva, antes solitária e cinzenta, mas onde conheci a ilusão do eterno. Ora, 0 fiel e a pedra foi uma tentativa de reconstituí-la, de refazer o meu reino devastado, tarefa que só através do romance poderia tentar. Pois eu também tivera destruída a minha Tróia, cujos muros pareciam-me inexpugnáveis. As alusões, no romance, a cheiros, a rumores, árvores e bichos, decorrem quase sempre daquela ânsia de prender a vida, que era o traço mais intenso de Ascânio; e à necessidade de fixar, ou de recuperar, uma vida que já não existe, necessidade hoje ultrapassada, porém que se tornou, na época em que concebi e elaborei este romance, irresistível. Eu queria reerguer, com amor e lucidez, o tempo da minha eternidade e, nele, tentar mover meus mitos, os heróis da minha infância, minha mitologia" (LINS: 1980, p. 43).

vi Além de uma privilegiada formação cultural básica, proporcionada por pais abastados, Públio Virgílio Marão, conheceu em Roma um poeta grego, Partênio, o qual ensinou as técnicas da poesia helenística, o que influenciou grandemente o jovem na composição de seus primeiros versos. Virgílio, como a maioria dos jovens de acesso à cultura, certamente haveria ouvido desde a infância, a lenda de Enéias, relato de um homem nobre e guerreiro, fugindo de uma cidade-reino em chamas e carregando o velho pai às costas - com os deuses do lar -, a esposa de um lado, o filho pequeno, de outro. A imagem comprova a entranhada vocação para 0 apego à família e à religião, caracterizadores do antigo povo de Roma e adjacências. A narrativa de que esse herói teria depois de voltas e mais voltas pelos mares, retornado à região para refundar sua nova Tróia era, ao mesmo tempo, inspiradora e motivo de imenso orgulho pátrio, embora a noção de pátria ainda não estivesse bem arraigada. Pierre Grimal comenta sobre a grande fama do herói Enéias: "Pois Enéias era considerado, em todo o mundo mediterrânico, um herói benfeitor. Dizia-se que impedira a destruição total de Tróia e estabelecera uma parte da população em terras vizinhas, onde esta prosperou". Diz Grimal que era conhecido o fato das ações e caráter desse herói: "Fundara várias cidades, e todos concordavam em reconhecer que em todos os lugares se comportara com a maior humanidade". E o estudioso conclui sobre o Enéias da tradição: "Já antes de Virgílio, ele é o herói 'bondoso' por excelência, e dizia-se que os deuses o protegiam, justamente em razão dessa virtude" (Grimal: 1992, p. 209-10). E tais circunstâncias foram observadas por Augusto, que, buscando alcançar a excelência desses sentimentos - orgulho das origens, admiração pelo caráter de piedade do herói -, começa por empenhar-se no enraizamento de um profundo amor a Roma, como foco da visão mítica. Augusto intentava despertar o olhar admirado das demais regiões, unificando os ideais em torno da Grande Cidade. Dela difundir-se-iam os raios de luz que uniriam os povos latinos numa só nação. Virgílio, o protegido de Mecenas e especial amigo de Augusto, acreditava nesses ideais. Sua formação epicurista levara-o a enxergar o homem como parte da terra, com objetivos de vida bastante delicados e serenos que envolviam o culto à família, à pátria e aos deuses. Tendo escrito vários poemas de sucesso, dentre eles, as Bucólicas e Geórgicas, o poeta decide se lançar na ambiciosa empreitada de escrever uma epopéia, cujos objetivos estivessem casados aos ideais de Augusto, acima relembrados.

vii Em vez de enfocar, única e exclusivamente, no enraizamento do amor à cidade de Roma e, conseqüentemente no senso de unidade latina, Virgílio opta por um caminho transverso: demora seu 
olhar sobre Enéias, fazendo dele o herói da narrativa. Enéias já era uma lenda entre os gregos, assim como os demais heróis que comparecem na llíada. E Andre Jolles fala sobre a lenda: "Trata-se um fenômeno de linguagem e de literatura. Sob o impulso de uma disposição mental, a língua denomina, produz, cria e significa uma figura derivada da vida real e que intervém, a cada instante, nessa vida real" (JOLLES: 1976, p. 50). Homero se apropriara da lenda e a inserira no contexto da guerra que é a base de llíada. Encantados com a ação do herói troiano, ao seu caráter acrescentaram outras virtudes, alterando sua forma, alguns poetas latinos já falavam de Enéias. Essa função é denominada pelos romanos antigos imitatio, que vem de imitor, a mesma raiz de aemulus (emular= procurar igualar ou procurar assemel har-se a), que, na Idade Média adquiriu o sentido popular de imitari de immutare: transformarse, mudar (JOLLES: 1976, p. 40). Com 0 transcorrer das eras, a lenda de Enéias fora transportada da visão que os gregos tinham do povo de Tróia e, segundo os postulados de Jolles, gradativamente atualizada nas terras itálicas. Jolles comenta os processos desse tipo: "Partindo da disposição mental a que chamamos imitatio, os fatos vividos cristalizam-se em gestos verbais, estando estes dispostos de modo a que possamos segui-los, penetrar neles e ser neles acolhidos. Em seu conjunto, eles estão orientados de tal sorte que, ao vincular-se a uma personalidade, tornam-se presentes e atuais" (JOLLES: 1976, p. 48). Virgílio adota esse herói, já transmudado, e planeja inseri-lo como herói literário. Enéias, já produto da assimilação dos ideais gregos aliados aos anseios de um poeta influenciado por Augusto, seria um herói mais humano, mesmo na qualidade de semideus. Seu perfil que mistura valentia ao temor; senso de missão e desejo de amar, sensibiliza, comove, atrai, porque é pura abnegação. Embora tão cruento e belicoso na llíada, seu caráter foi sendo modificado. 0 autor de Forma simples, diz: "E quando Virgílio inicia a sua epopéia com Arma virumque cano para vincular, em seguida, mediante uma ficção poética, o herói troiano Enéias à história de Roma, e concluir a sua Introdução com as palavras tantae molis erat romanam condere gentem, é ainda e sempre a legenda que transparece sob uma forma iminentemente artística." (JOLLES: 1976, p. 57).

viii Carlos Alberto Nunes diz na Introdução de Odisséia traduzida por ele: “O herói da Odisséia (...) aparece-nos como homem maduro, de grande e variada experiência e com admirável domínio de si mesmo (...)" (Od, Introdução). E continua o estudioso e tradutor: "Na figura de Odisseu viam os gregos o retrato do herói ideal, até mesmo nos defeitos: astucioso, sofredor, resistente, rico em recursos de toda natureza, que o faziam triunfar das mais delicadas situações" (Od, Introdução).

\footnotetext{
${ }^{i x}$ No prefácio da edição de Os lusíadas que ora utilizamos, Afrânio Peixoto considera o diálogo entre textos (se bem que não empregue o termo) notadamente apreensível no poema épico lusitano, tecendo interessantes pontuações sobre o fenômeno de absorção de um texto por outro, fato que se mostra, em geral, bastante evidente na maioria dos textos literários e até mesmo na oralidade:

"É de La Bruyère a afirmativa que a menor de nossas idéias tem idade pelo menos de sete mil anos, pois que não nos é possível ir mais atrás ainda. (...) Um autor é alguém que expressa em suas palavras idéias comuns e anônimas, que colheu da vida ou de outros autores, como ele. Por isso se diz que o povo fala pelos seus autores, mais propriamente a Humanidade, por alguns homens. (...) 0 poema épico seria formal imposição coletiva, com materiais de outrem, feito pelo gênio e pela cultura pessoal". (CAM ÕES: 1956, Introdução, p. XVI). Afrânio Peixoto lembra o quanto Virgílio foi criticado pela apropriação dos poemas homéricos em seu texto épico: “Da Eneida se disse ser uma 'contaminação' equitativa, seis livros para uma, seis para a outra, das linhas gerais aos detalhes, - da llíada e da Odisséia. Apontam-se jóias do poema que são pérolas, catadas 'no esterco de Ênio', como o Poeta confessava. Macróbio afirmou, 0 2‥ livro é traduzido, literalmente, de um poema de Pisandro. E os Argonautas, de Apolônio de Rodes, a Guerra de Tróia, de Quinto de Smirna, até a Medéia, de Eurípedes, contribuíram. Perilo Faustino e Octávio Avito reuniram versos roubados e passagens imitadas, formando volumes." (idem, ibidem). No entanto, continua o escritor, as críticas dos que não compreenderam a finalidade da "imitação" que o poeta mantuano executou não obliteraram o brilho da epopéia latina que se imortalizou e, mais, se multiplicou em novos textos: "Ainda assim subsistem Virgílio e a Eneida, o divino poema das origens religiosas de Roma. Dante Alighieri disse desse Virgílio que fora 'tu sei il mio maestro e il mio dottore', para confessar o que lhe devia de inspiração... Sainte-Beuve mostrou que todos os grandes poemas europeus, em verso e prosa, antigos e recentes, são descendentes da Eneida: da Jerusalém Libertada à Francíada, do Paraíso Perdido aos Mártires do Cristianismo. Camões como os outros. A Eneida está nOs lusíadas. No lineamento geral do poema, como nos episódios, em estrofes seguidas, no detalhe, frases, epítetos, palavras. Começa, pelo começo, Arma virumque cano... 'As armas
} 
e os barões... cantando espalharei'... e vai até o fim 'imitando el Poeta en todo a Virgilio', como diria o arquicamonista, Faria e Sousa, para insistir e provar, exaustivamente, 'en esto como en todo imito a Virgilio'. Camonista e português como o outro, Epifânio Dias escreveu d'Os lusíadas: 'uma epopéia moldada na Eneida'." (idem, ibidem).

${ }^{x}$ ARISTÓTELES, HORÁCIO, LONGINO. A poética clássica. Tradução do grego e latim por Jaime Bruna. São Paulo, Cultrix, 2005, VI, p. 20.

${ }^{x i}$ Especificamente sobre a gênese de 0 fiel e a pedra, Osman Lins diz: "Sou mais influenciado por livros que por autores. Assim, para essa minha última obra [0 fiel e pedra], 0 velho e o mar, de Hemingway, Terra dos homens, de Saint-Exupéry... e, principalmente, a grande epopéia clássica de Virgílio, Eneida, trouxeram colaboração, pois em todas nota-se a afirmação do homem em si mesmo e a crença em valores espirituais" (Entrevista concedida por Osman Lins para 0 Diário de 6 de abril de 1960, in IGEL: 1988, p. 49). Quanto à atração que o escritor detinha pelos livros, ainda em criança, em artigo intitulado Tributo à Coleção Nobel (publicado no livro Evangelho na taba...) Osman Lins expressa profunda gratidão a essa coletânea de livros, da qual se abeberou intensamente: "Horas das mais valiosas da minha vida foram dedicadas à leitura. E dessas, grande parte é devida à edição da Nobel. Eis-me numa sala do interior, ao lado do velho piano de minha irmã, lendo Não Estamos Sós, de James Hilton; eis-me num quarto de pensão do Recife, iniciando a leitura de Jean Christophe; eis-me convalescente, sob uma jaqueira, lendo, em manhãs e tardes de verão, Os Thibault (...)" (ET, 77). A intensa manifestação continua: "E o meu testemunho sobre ela [sobre a referida coleção] - eu diria melhor: o meu depoimento comovido - não é apenas o de alguém que mais tarde viria a escrever e que confessa haver encontrado, nos primeiros anos da sua aprendizagem, em certos textos daquela coleção - como, lembro-me bem, na versão de Lord Jim feita por Mário Quintana -, tons e soluções frásicas que eu buscava, sem encontrar, em originais da nossa língua. Como aliás, encontraria em Orlando, de Cecília M eireles, e no Retrato do Artista Quando Jovem, de José Geraldo Vieira, páginas de prosa que, sem serem superiores ao que eles pudessem escrever, tocavam-me de um modo estranho e novo" (ET, 77). Nas entrevistas publicadas em Evangel ho na taba..., Osman Lins elenca muitas outras obras de literatura. São citados autores de renome como: Faulkner, Richard Llewllyn, Thomas Mann, Lion Feuchtwanger, Louis Bromfield, André Gide, Pearl S. Buck, Katherine Mansfield, Thornton Wilder, Charles Morgan, Theodore Dreiser, Somerset Maugham, Huxley, Proust e outros - um rol que segundo Osman Lins era "variado, exaltante, enriquecedor" (ET, 77), se bem que todo composto de escritores estrangeiros em vista do programa editorial da coleção. Em outro artigo intitulado Estudos Literários e Realidade Cultural, depõe a favor de obras nacionais: "Quando falamos no fascínio que sobre nós exerce a Capitu de Machado de Assis ou do modo como Paulo Honório, de Graciliano Ramos, constrói e perde seus bens, decerto valorizamos (...) esses livros tão diferentes e a arte dos homens que os escreveram" (ET, 79). Nesse mesmo livro, encontramos referências a vários escritores, como James Joyce, Unamuno, Rainer M aria Rilke, Flaubert, Saint-Exupéry, Kafka e outrosi [ET, p. 123-4 (Joyce); 131 (Unamuno); 43 (Rilke); 134 (Flaubert); 145 (Saint-Exupéry); 157 (Kafka)].

xii Em sua infância, Osman Lins muito apreciava as sessões domingueiras do cinema de sua cidade, em que os filmes de cowboys era atração constante. 0 menino se maravilhava com o heroísmo das personagens marcantes nos roteiros hollywoodianos. 0 autor de 0 fiel e a pedra escreveu artigo sobre 0 assunto: Qual é o filme de hoje? Em que diz: “(...) Vinham a nós, nas salas refrescadas por ventiladores e imensos cartazes dos próximos filmes pregados nas paredes, os corajosos e invencíveis heróis do Oeste - Ken Mayanard, Buck Jones, Tim M cCoy, Gary Cooper -, bailarinos, cantores, espadachins, conquistadores irresistíveis, mulheres fatais, vampiros, crianças prodígio, dominadores das selvas, animais amestrados, os grandes cômicos (...). A tela do cinema era uma porta de acesso ao mundo" (ET, 103). Depois da morte de Osman Lins, em artigo homenageador, Julieta de Godoy Ladeira, a segunda esposa, escreveu: “(...) 0 menino [Osman Lins] (...) criado pela tia cuja suavidade mais tarde retrataria num romance ( 0 fiel e a pedra) e pela avó (...) sente-se fascinado pelos atos de heroísmo, pela integridade, pela coragem e o desprendimento da personagem que depois do cinema, em casa, voltaria a encontrar, encantando sua infância, na figura de seu tio Antônio Figueiredo, narrador e personagem, ele próprio, de incríveis façanhas vividas pelo Sertão e pela Zona da Mata, levando tropas para vender em distantes cidades ou fazendo peças de ouro ou pondo simplesmente o chapéu meio de lado e entrando em casa falando muito alto de brigas em defesa de algum princípio ou de algum injustiçado." 
(LADEIRA, Julieta de Godoy. Ele foi “Beau Geste" até morrer. Correio do Povo. Porto Alegre, 30 set. 1978, Caderno de Sábado, p. 5).

xiii 0 visitante, efetivamente, um romance bem elaborado e instigante, foi originalmente um texto escrito em 1953 e enviado para um concurso literário de Pernambuco, no qual obteve o segundo lugar. Remetido ao Concurso Fábio Prado, em São Paulo, em 1954, sagrou-se, com unanimidade, vencedor em primeiro lugar, provocando o orgulho da crítica pernambucana. Ariano Suassuna chegou a escrever três artigos elogiosos acerca do jovem e desconhecido expoente das Letras e seu conterrâneo. 0 romance foi publicado em 1955 e premiado em duas outras oportunidades (conferir em IGEL:1988, p. 43-6). Em entrevista concedida ao Diário de Pernambuco, após ser homenageado com o Prêmio Fábio Prado, em maio de 1954, Osman Lins informa sobre o projeto - ainda incipiente, mas já esboçado - de escrever sobre sua infância: “(...) é possível que eu tente uma espécie de biografia da rua onde passei a minha infância. Da galeria de tipos que habitavam aquelas casas hoje demolidas. De vez em quando eles me surgem, sós e em grupos, com uma nitidez enorme. Aliás, tenho sofrido, de certo tempo para cá, uma espécie de volta não só às paisagens da minha infância e adolescência, como a certos fatos a elas vinculados. É uma sedução muito forte cujos motivos desconheço" (ET: 1979, p. 128).

xiv Vale lembrar que, no poeta lusitano, Osman Lins enxergou duas aptidões da arte literária: a sensibilidade ao discorrer sobre o amor, bem como na habilidade para unir cristianismo e politeísmo.

${ }^{x v}$ Em ensaio intitulado "Quand Osman Lins faisant ses armes", em La Quinzaine littéraire, no. 550, Paris, 1-15.03. 1990 e traduzido no Brasil para Quando Osman Lins preparava suas armas, e inserido no livro Inútil poesia e outros breves ensaios, Leyla Perrone-Moisés, afirma: "É pois um romance de cavalaria ou um western (a versão moderna do gênero medieval) que nos é oferecido por Osman Lins. Romance épico (as epígrafes colhidas na Eneida e nos Lusíadas o confirmam), romance ético, sobretudo. 0 herói dessa história capta nossa simpatia, não por seu heroísmo à antiga, mas por suas dúvidas e escrúpulos, que o colocam na categoria moderna do "herói infeliz". (PERRONE-M OISÉS: 2000, p. 231).

A estudiosa também insere, no segundo parágrafo do ensaio, a informação de que os editores da tradução francesa de 0 fiel e a pedra - Le fleau et la pierre - feita por Maryvonne Lapouge-Petorelli e Claude Barousse, para Actes Sud/ Unesco, em 1990, consideraram a obra como o romance mais importante produzido pelo autor. Leyla Perrone-M oisés faz sua ressalva: "Sim, se pensarmos no sentido tradicional da palavra romance, e não considerarmos a obra ficcional posterior de Osman Lins" (idem, ibidem, p. 230). Outro ponto a relacionar como dado relevante de crítica é a conceituação que se segue: "O fiel e a pedra inscreve-se ainda na tradição do romance regionalista do Nordeste, que conheceu seu grande momento nos anos 30 e 40" (idem, ibidem, p. 230). Portanto, se comprova o caráter dúbio de 0 fiel e a pedra, aspecto que enfatizamos: poderíamos inserir a obra entre as produções brasileiras de 1930-40; porém, sua ligação com as epopéias é intensa e o diferencia dessa expressão. Reside nisso a grande força da obra, algo que constatamos numa leitura intertextual mais acurada, como se pode observar no conteúdo desta reflexão. Falando sobre Bernardo como legítimo representante de uma classe de trabalhadores explorados no ciclo da cana-de-açúcar, Leyla Perrone-M oisés diz: "O fim do ciclo do ciclo da cana-de-açúcar produziu, de repente, uma geração de aristocratas empobrecidos, rebeldes a qualquer nova forma de autoridade, vivenciando a infelicidade social, como infortúnio pessoal. Cavaleiros errantes em pleno século XX, esses Quixotes viam inimigos escondidos em toda parte e combatiam, menos para vencê-los do que para afirmar os antigos valores segundo os quais tinham sido criados" (idem, ibidem, p. 231).

${ }^{x i}$ Bakhtin relembra o fato de que toda linguagem está impregnada de outras e todos os nossos discursos apresentam multiplicidade de vozes, essas sendo misturadas à nossa voz e admite que, mesmo aceitando as idéias do outro, criamos sobre tais idéias. Estudando Dostoiévski, Bakhtin constatou que o romance desse escritor russo evidencia a polifonia inerente à vida humana, tornando seus personagens não um eco de sua voz exclusivamente, mas seres parecidos com as pessoas, com uma consciência revestida de pluralidade de vozes. Bakhtin apontou para o fato de que Dostoiévski diferenciou-se dos demais escritores de seu tempo por inserir em seus romances a polifonia tão distinguível nas relações humanas. Segundo o estudioso, o texto do grande escritor russo é como uma construção de muitas vozes e essa polifonia resgata os elos com a história, revelando-se por si só um entretecimento de ideologias múltiplas. Refletindo so bre a obra de Dostoiévski, Bakhtin classifica os 
romances como monológicos ou polifônicos, isto é, dotados de uma voz única - a do autor - ou de múltiplas vozes - que o romance como um todo, narrador e personagens discutem. No primeiro caso, 0 autor escamoteia os demais discursos e faz prevalecer o seu; no segundo, escancaram-se os vários discursos nas falas das principais personagens. Nessa categoria, 0 autor mostra suas personagens pensando, e nesse pensar, retomando as palavras dos outros, analisando-as, remoendo-as mesmo, ratificando-as ou delas discordando. M ostra também personagens atentas e incomodadas com a opinião dos outros, enfim, não tão seguras e individualizadas. (BAKHTIN: 1998).

xvii Ferdinand de Saussure, em 1908, preconizava ser o poema um discurso tecido entre dois textos e conceituou tais textos como hipogramático e paragramático, o discurso poético como produto de reescrita expandida. luri Tinianov, por volta de 1919, defendia a idéia de uma crítica não-imanente, justificando que a obra literária se faz com uma rede de relações entre os textos antecedentes e abordando a ocorrência da citação e explicitava que um texto literário não provém direta ou exclusivamente de uma língua natural, mas resulta de outro texto literário anterior. Victor Chklovski, nos anos de 1970, argumentava de que o discurso poético é um fato em construção e que a obra de arte é construída tendo como base um modelo. Gérard Genette expôs o fato, às vezes facilmente comprovável, de um texto em outro, através de apropriação parafrasástica, paródia ou mesmo cópia literal. M ukarovsky seguiria os mesmos conceitos, acrescentando ainda que a obra literária não se faz sozinha (CHKLOSVKI, EICHEM BAUM, TINIANOV, et alii: 1971; GENETTE: 1982; SCHNAIDERM AN : 1979).

xviii Osman Lins via com bons olhos o empréstimo de um texto por outro e mesmo a chamada inspiração que uma obra exerce sobre outra. Aos que defendiam o purismo da literatura brasileira, 0 autor, na qualidade de crítico da educação, relembra a rede de inter-relações literárias, em ousado artigo de outubro de 1977, cujo título é Os Futuros Inquisidores. Dessas páginas extraímos o excerto a seguir: "Ignora, por acaso, essa nova versão de ideologia curupira, a constante, imensa, fecunda e necessária rede de permutas e influências que tem vivificado a literatura? Que o romano Virgílio imita o grego Homero? Que o florentino Dante, por sua vez, é conduzido ao Paraíso por Virgílio? Que um dos mais importantes romances do século, do alemão Hermann Broch, chama-se A morte de Virgílio? Que Camões se abebera em toda a tradição clássica? Já ouviram falar na influência de Camões sobre M elville, estudada pelo professor Alex Severino, da Vanderbilt University? Desconhecem a influência de George Sand e do folhetim francês sobre um gênio como Dostoievski? Que dizem do francês Baudelaire haver traduzido e divulgado o norte americano Edgar Allan Poe? E de outro francês, Diderot, haver retomado em Jacques, o Fatalista, um tema do Tristram Shandy, do inglês Sterne? E que dizer da presença do espanhol Cervantes na literatura mundial, através do seu Quixote? São contra a influência do teatro grego, que chega até Gota d'Água?" (ET, 69)

${ }^{x i x}$ Sendo o discurso do narrador ou das personagens principais tão contaminado pelo discurso do outro, Bakhtin o denomina-o discurso bivocal. Tal conceito pressupõe uma via de mão dupla, como teórico especifica e amplia o assunto: "As relações dialógicas são irredutíveis às relações lógicas ou às concretosemânticas, que por si mesmas carecem de momento dialógico. Devem personificar-se na linguagem, tornar-se enunciados, converter-se em posições de diferentes sujeitos expressas na linguagem para que entre eles possam surgir relações dialógicas". Bakhtin preconiza que o dialogismo pode ocorrer entre outros elementos da narrativa e também entre artes diferentes: “(...) numa abordagem ampla das relações dialógicas, estas são possíveis também entre outros fenômenos conscientizados desde que estes estejam expressos numa matéria sígnica. Por exemplo, as relações dialógicas são possíveis entre imagens de outras artes (...)" (BAKHTIN: 1998, p. 183-4). Bakhtin, nesse mesmo compêndio, às páginas 190-3, aborda o conceito de estilização e paródia, já amplamente conhecido.

${ }^{x x}$ Julia Kristeva, tendo como pressupostos os estudos bakhtinianos emprega o já bastante difundido termo intertextualidade para o que ela denomina "absorção e transformação" de um texto por outro. In KRISTEVA, Julia. Introdução à semanálise. Tradução de Lúcia Helena França Ferraz. 2. ed. São Paulo: Perspectiva, 2005, p. 68. Outras palavras e expressões idiomáticas para o mesmo assunto (o uso de palavras, idéias de um texto em outro) serão utilizadas neste trabalho, como empréstimo literário, apropriação, etc., sem autoria definida, tampouco de uso restrito a alguma teoria. Apropriação, por exemplo, não tem o sentido proposto pelos estudiosos do dadaísmo ou da assemblage dos anos 60. 
xxi Termos subseqüentes aos de Bakhtin e propostos por Genette ${ }^{x x i}$, como intratextualidade, paratextualidade, arquitextualidade e metatextualidade não serão contemplados, não pela discordância que se possa ter em relação aos mesmos, mas pela tentativa de evitar abrangência excessiva de olhares. De igual modo justifica-se o não uso de nomenclatura posterior para os fenômenos literários aventados.

xxii 0 que hoje é considerado um "clássico" foi popular em seu tempo... Odisséia, por exemplo, atraiu o fascínio das multidões, mesmo em seu tempo... Os poemas épicos de Virgílio eram encenados ao público e o tornaram famoso e querido mesmo antes de haver escrito Eneida. (relevando incompatibilidades, conferir em BELLESORT: 1949; CARCOPINO: 1968; FIOL: 1952; FIORE: 1946; GRIM AL: 1992/200; PARATORE: 1983 - Grimal, por exemplo, fala da projeção de Virgílio desde a apropriação dos escritos pelo teatro: "Ignoramos em que momento as Églogas começaram sua carreira teatral. Sabemos apenas que, à época em que Virgílio dividia seu tempo entre Roma e Nápoles (...) estas eram freqüentemente representadas diante do público de Roma e faziam grande sucesso, a tal ponto que [citando Tácito, no Diálogo dos oradores] os espectadores, reconhecendo o poeta no teatro certo dia (...) se levantaram espontaneamente e lhe prestaram uma homenagem, como faziam ao próprio Augusto" (GRIM AL:1992, P. 90). O povo, portanto, consagrara as produções mencionadas e isso porque elas Ihes falavam ao espírito. Vale lembrar que, no caso da Odisséia, não há certeza quanto ao seu verdadeiro autor (também para o caso de llíada). Homero bem pode ter sido um ilustre coletor de lendas e poemas advindos de autoria "popular" (conferir na Introdução de Carlos Alberto Nunes, de Odisséia em: HOM ERO. Odisséia. Tradução de Carlos Alberto Nunes. 3. ed. São Paulo: Melhoramentos, 1960; e, mais uma vez, pondo à parte as possíveis divergências de pensamento: FINLEY: 1988/1998; VERNANT: 1990/2003; VERNANT, VIDAL-NAQUET: 2005; VIDAL- NAQUET: 2002) . Por exemplo, já na Introdução, Vernant atribui aos aedos a tentativa dos gregos da chamada "idade homérica" de resgatar e entender a civilização micênica da qual se originavam (VERNANT: 2003).

xxiii Osman Lins informa a fonte de sua citação: “VIRGÍLOO, Geórgicas, Ivr. I” (OFP, citações iniciais).

xxiv Em sua Poética, Aristóteles conceitua os elementos estruturais da tragédia, um gênero que 0 estudioso considera, de certa forma, emparelhado à epopéia, pois ambas "imitam" "seres superiores": mito, ou fábula; caráter; elocução (ou fala); pensamento (ou idéia); espetáculo e melopéia, ou canto (ARISTÓTELES. Poética. Organon. Política. Constituição de Atenas. São Paulo: Nova Cultural, 1999, V; VI, 26-39, p. 43-5).

${ }^{x \times V}$ FINLEY: 1988, p. 108.

xxvi Epítetos de Aquiles (in CAM POS: 2002 e CAM POS: Arx, 2002): pés-velozes (I, 58, 121, 148; II, 686-7; IX, 607, 644; XI, 600, 606); pés-velozes (III, 348; XVI, 5, 48, 166, 281, 865; XVIII, 186, 232, 260; XIX, 145, 296; 420; XX, 45, 176, 413-4; XXI, 210, 222, 247; XXII, 8, 261, 375; XXIII, 141, 333, 532, 553, 794, 889; XXIV, $139,647,751$ ) e também comparecem os correlatos pés-rápidos (XVIII, 78) e pés vigorosos (XXIV, $670)$.

xxvii Outros epítetos ligados à valentia de Aquiles: rompe-tropas (XIII, 324; XVI, 146); rompe-esquadrões (XVI, 575); temível Aquileu (XVIII, 260); furioso (XXII, 144); mortífero (XXIV, 40); fogoso (XXII, 229); Peleide insaciável de guerra (XX, 2-3); e outros epítetos relacionados à atuação na guerra: 0 mais forte, 0 magno fazedor de malfeitos entre os homens (XXI, 214-5); forte (XXI, 554); o mais forte dos Aqueus (XVI, 21-2); fortíssimo (XXI, 194); fulgurante (XXI, 583); ícone aquilino (XXI, 254); [comandante] pastor-depovos (XVI, 3); entre os Aqueus o mais forte em toda a armada (XVI, 271-2); grande-de-ânimo (XVII, 214); ânimo-grande (XXI, 153); meganimoso (XXIII, 168); sobre-animoso (XX, 88-9; XX, 332-3; XX, 345); formidável (XXI, 528); gigânteo (XXII, 92); ilustre (XXI, 161).

xxviii Alguns exemplos comprobatórios dos epítetos de Odisseu (in HOM ERO: 1960): audacioso (X, 436); experiente (XXII, 371); famoso (XII, 184); de alta fama (III, 98); muito famoso (VIII, 503); glorioso (X, 251; XXII, 90); grande (IV, 143, 151; XVI, 100, 407; XX, 209; XXI, 74; XXII, 141; XXIV, 100, 446); herói Odisseu (II, 415; IV, 715; VI, 14; XIV, 321; XV, 59, 337; XVI, 34; XVII, 152; XIX, 262, 270, 447; XX, 117, 122, 286; XXI, 158; XXII, 221; XXII, 310, 495; XXIII, 89); ilustre (XI, 202); impecável herói (XIX, 456); impecável (XXI, 99); nobre (IV, 741; XVI, 139; XIX, 336); dos Aquivos orgulho (XII, 184); potente (IX, 504); 
preclaro [ilustre, famoso, notável, brilhante, formoso] (II, 225; III, 219; V, 486); preclaríssimo (XI, 100); valente (I, 207); valoroso (II, 238; XV, 347; XVII, 314; XXIV, 541).

xxix Epítetos de Enéias, ligados à audácia (in VIRGíLIO: 2004): valoroso Enéias (IX, 110); fatal Enéias (XI, 301); Indígite Enéias (XII, 1087).

${ }^{x x x}$ Epítetos: (in CAM POS: 2002 e CAM POS: 2002) voraz de guerra (XIII, 469-70); pés-rápidos - matador de gente, terrível (XIII, 483; XVI, 619-26); animoso (V, 534); bravo ( XVII, 753; XX, 174); grande-ânimo ( $X X, 175)$.

xxxi Para esclarecer o termo imperativo, Kant assim define-o: “A representação de um princípio objetivo, enquanto obrigante para uma vontade, chama-se mandamento (da razão), e a fórmula do mandamento chama-se Imperativo. Todos os imperativos se exprimem pelo verbo dever (...)" (KANT: 2007, p. 48). Kant lembra que devemos agir pensando que nossa atitude poderia se tornar em regra seguida por todos: "Age apenas segundo uma máxima tal que possas ao mesmo tempo querer que ela se torne lei universal" (Idem, ibidem, p. 59).

xxxii Kant adverte em um de seus pressupostos: "Age de tal maneira que uses a humanidade, tanto na tua pessoa como na pessoa de qualquer outro e simultaneamente como fim e nunca simplesmente como meio" (KANT: 2007, p. 69). Ou ainda: "Toda ação que toma seus móveis da sensibilidade, dos desejos empíricos, é estranha à moral, mesmo que essa ação seja materialmente boa" (HUISMAN, VERGEZ: 1982, p. 261). As indagações íntimas do pequeno Bernardo parecem combinar com o comentário de Huisman e Vergez, numa tentativa esclarecedora da visada kantiana, a qual, mesmo sem se aperceber, 0 menino defende: "A moral de Kant, ao privilegiar a razão humana, exprime sua desconfiança com relação à natureza humana, aos instintos, às tendências de tudo o que é empírico, passivo, passional, ou, como diz Kant, patológico. Tal é o rigorismo kantiano. A razão fala sob a forma severa do dever porque é preciso impor silêncio à natureza carnal, porque é preciso, ao preço de grande esforço, submeter a humana vontade à lei do dever" (idem, ibidem, p 262).

xxxiii Outros exemplos da potente ira de Aquiles: "Aquiles irritado disse ao coração / mega-animoso (...)" (II, XXI, 53-4). Também encontramos um exemplo da constatação desse furor bélico na frase que o rio Escamandro diz a Aquiles: "(...) 'Aquiles, o mais forte, o magno / fazedor de malfeitos entre os homens! (...)" (II, XXI, 214-5) ou: "Acometia-os Aquiles com lança impetuosa, / o coração colérico, ávido de glória" (II, XXI, 543-4). Ou ainda: “(...) O iroso / ultrajava o divino Héctor. (...)" (II, XXIV, 22-3).

${ }^{\text {xxxiv }}$ PAZ: 2003, p. 38.

${ }^{x x x y} \mathrm{~A}$ ira de Aquiles é, sem sombra de dúvida, a pedra angular de toda a llíada, conforme se vê no verso introdutório: "A ira, Deusa, celebra do Peleio Aquiles $(. .$.$) " (II, I, 1), sendo a causa do abandono da guerra$ - por parte do injuriado, o que levará à extensão do período de conflito, propriamente dito, e, conseqüentemente, a multiplicação das mortes entre os gregos e os troianos, atingindo, principalmente, a ele mesmo, com a morte de Pátroclo. Portanto, embora façamos referência, vez ou outra, às demais iras, de modo mais significativo, é à grande, portentosa e ambivalente ira de Aquiles que volveremos nosso olhar investigativo, na busca de similaridades e diferenças entre essa e a ira de Bernardo, por se tratar de ser ambas compostas por sentimentos multi-expressivos.

xxxui As causas primárias da ira em Odisseu são as atitudes agressivas, insistentes e inconvenientes abusivas mesmo - dos homens que pretendiam conquistar a sucessão do reinado de Ítaca, uma vez que o rei da cidade-estado não retornava da guerra de Tróia, encerrada há tempos. Os "pretendentes", como são chamados na epopéia, exigiam que Penélope sem mais delongas escolhesse o novo esposo, e para forçar uma resposta favorável, instalaram-se no palácio, despendendo o tempo em jogos, bebedeira e comilança, depauperando o patrimônio do herói. Os bens de Odisseu estavam se esvaindo com o passar dos anos, e, portanto, havia urgência de acabar - literalmente - com a festa. Como causa subliminar da ira de Odisseu está de igual modo, a disputa de autoridade entre os pretendentes e o rei e seu herdeiro. Perante a prepotência dos auto-empossados herdeiros, Odisseu sublevará a ilegal estrutura por eles instalada: "Cães, não pensáveis, decerto, que um dia voltar eu pudesse / lá da planície 
de Tróia, e por isso meus bens arruináveis, / às minhas servas fazíeis violências sem conta, aqui dentro, / e pretendíeis a esposa, apesar de que eu vivo estivesse" enunciando as ações e reafirmando a ilegalidade das mesmas: "sem terdes medo dos deuses eternos que moram no Olimpo / nem da vingança dos homens, que um dia pudesse alcançar-vos", assim como, ditando-Ihes a sentença para seu crime: "Sobre vós todos, agora, já impendem as malhas da Morte" (Od, XXII, 35-41).

xxxvii A causa aparente da repentina e terrível ira de Enéias é a usurpação ilegal de um bem precioso aos guerreiros - releitura de llíada - a armadura ou parte dela, em geral, autêntica jóia, tanto pelo material e primor com que era confeccionada, quanto pelo simbolismo que carregava em si - afinal, era uma espécie de elemento metonímico, bem representando o valente que as portava. No caso, as peças da vestimenta bélica de Palante, o filho do rei Evandro, usurpadas ilegalmente por Turno são a causa da grande e súbita ira de Enéias, sentimento que se apossa do herói e o leva a matar ferozmente 0 adversário. Assim, em todos os casos, bens estão envolvidos na causa da ira do herói. A causa oculta é a disputa de poder entre Turno, o ex-futuro herdeiro do trono do rei Latino e o novo futuro rei, segundo as intenções divinas. Apossando-se do talabarte, Turno demonstrava a intenção expansionista de seu império, colocando-se em lugar de seu dono, o sucessor de Evandro, o rei da cidade-estado que seria incorporada aos domínios do vencedor. Por se tratar de um objetivo contrário ao desejo de Zeus, esses planos se assumiam ilegais, portanto, 0 uso do talabarte era uma usurpação duplamente ilegal: pela conspurcação do cadáver e pela ímpia posse. Diante da arrogância de Turno em se apossar do símbolo dos domínios de Evandro, o parceiro de Enéias na construção do novo império de Roma, Enéias se insurgirá: “Dos despojos dos meus, tu revestido / Das mãos hás de escapar-me? Não! Palante , / Palante co'este gol pe é quem te imola" (En, XII, 1275-4). A disputa de autoridade entrevista em Eneida remete aparentemente à llíada, pelo fato de, como Agamenon usurpa o prêmio de Aquiles e também Heitor se apossa ilegalmente da armadura divina usada por Pátroclo. A armadura de Aquiles havia sido confeccionada por Hefesto e só poderia ser vestida por um semideus ou alguém a quem esse conferisse o dom, sendo, portanto, um símbolo da junção diática divindade-humanidade. Virgílio se apropriara desse imagem simbólica ao inserir o talabarte de Palante como representativo de seu possuidor, 0 substituto do aliado de Enéias, o rei grego Evandro, sendo esse último, um lado importante da aliança grego-troiana.

xxxviii Quanto às nuanças da ira de Aquiles, essas não comparecem todas na ira de Odisseu, mais simples e direta. Ele apresentará inflexibilidade na execução de seus planos e o desejo, que se concretiza em ação, de matar de vez os pretendentes. A ira de Odisseu difere da de Aquiles por conter em si o estatuto de procedimento punitivo, ou seja, o herói não se consome em ira, como ocorre com o famoso semideus grego da llíada, mas torna-se um instrumento da ira divina para castigar os pretendentes a quem odiava, é certo, mas com um sentimento que se esvai na ação. A comprovação desse fato vem no excerto "a minha mão não deixara, por certo, de a morte aprestar-vos, / antes que todos os moços houvésseis as culpas expiado" (Od, XXII, 63-4) e também nos versos: "Estes tombaram por obra dos deuses e próprios delitos" (Od, XXII, 413). Ao arauto Medonte, após a matança dos pretendentes dará a incumbência de contar aos outros que tudo o que ali se passara estaria contido no ritual do juízo vingador: "para que o saibas no espírito e possas contar aos teus sócios / quanto às ações reprováveis as boas em tudo superam"(Od, XXII, 373-4). Odisseu nem permite que a serva se alegre com a desdita dos pretendentes, demonstrando o quanto está isento de raiva o seu ato de juiz executor: "Goza calada, velhinha; a essa grata expansão não te entregues, / pois é impiedade mostrar alegria ante um corpo sem vida" (Od, XXII, 411-2). Logo, uma ira não tão complexa, não mesclada de outras características do herói que a detém, se vê em Odisseu, já que em sem âmago o sentimento admite causas opostas [a ira é o veículo em que se concretiza o castigo divino]. Virgílio menciona um irado Enéias, em alguns momentos da epopéia, como por exemplo, ao constatar a tomada de Tróia: "Ira e furor a mente me alucinam" (En, II, 488) - uma ira que levará seu possuidor à guerra, ao sacrifício de si mesmo em função da pátria. 0 poeta, entretanto, deve ter-se inspirado na ira de Aquiles para inserir o episódio de Enéias ardendo em ira, ao final de seu texto. No entanto, essa assimilação é parcial, por alguns aspectos. Primeiramente, 0 bondoso, piedoso Enéias virgiliano será lembrado bastante por seus medos e insegurança, como no episódio da tempestade. Ante a fúria natural, veja-se a reação do herói troiano: “N'isto Enéias, d'um frio horror tomado, / Geme, e ambas as mãos aos céus erguendo, / Oh mil vezes, exclama, venturosos / Os que de Tróia junto aos altos muros / À vista de seus pais morrer puderam!" (En, I, 128-42). Enéias, que somente vez ou outra se apresentará corajoso, titubeará ante as súplicas de Turno e quase o deixará 
impune. Assim, sua ira ardorosa e fulminante será um sentimento unívoco, quase um lampejo na história do magnânimo tróico, e se manifestará segundos após de uma atitude branda - ou, pelo menos, de vacilação. Em segundo lugar, Enéias matará o adversário em nome de Palante: "Palante co'este golpe é quem te imola" (En, XII, 1284), desabilitando a autoria de seu gesto, exatamente por ser tão incoerente ao seu caráter. Assim, 0 ato sacrílego de Turno se volta contra ele mesmo no julgamento que Enéias faz e o senso de justiça inserido na sentença de juízo não admite misericórdia. Assim, a ira de Enéias assemelha-se a uma parenta longínqua da ira de Odisseu, dado seu componente punitivo.

xxxix No banquete do rei Alcínoo, o próprio herói se apresentará por tal qualidade: "Sou de Laertes o filho, Odisseu, conhecido entre os homens / por toda sorte de astúcias; bater foi no céu a minha glória" (Od, IX, 19-20). Essa auto-resolução diante da iminência do acerto com Nestor - que Bernardo bem sabia de qual natureza viria, não nos lembra Odisseu, ante a proximidade da morte, na caverna de Polifemo, pensando "toda sorte de astúcias e enganos, / por se tratar da existência e iminente perigo ameaçarnos" (Od, IX, 422-3)? . O filho de Odisseu, Telêmaco, comentará a fama paterna: "dizem-nos todos, o mais astucioso de ser tens a fama, / sem que mortal sobre a terra contigo se atreva a medir-se" (Od, XXIII, 125-6). A deusa Atena chamará o herói de "sábio Odisseu" (Od, I, 48) e mais adiante confirmará essa característica: "Simulador sem defeitos seria quem te superasse / em qualquer sorte de astúcia, ainda mesmo que fosse um dos deuses. / Ó astucioso e matreiro incansável, nem mesmo na pátria / resolverás pôr à margem, de vez, esta sorte de embustes / e de artimanhas falazes, que tanto condizem com tua alma?" (Od, XIII, 291-5). A sagacidade de Odisseu o faz desconfiar das pessoas, condição que Atena confirma: "Sempre há de ter em teu peito acolhida uma tal desconfiança!" (Od, XIII, 330). E 0 curioso é que a deusa também se enxerga da mesma maneira: "Bem, mas deixemos de lado essas coisas, porque ambos na astúcia / somos peritos. No meio dos homens salientas-te sempre / pelos discursos e planos; no círc'lo dos deuses sou célebre / por minha astúcia e saber. (...)" (Od, XIII, 296-9).

${ }^{x l}$ Epítetos ligados à sabedoria, engenhosidade de Odisseu, na llíada: multiardiloso (II, I, 311); equiparado a Zeus em argúcia (II, II, 170-1); multiastucioso (II, IV, 328-9); doloso em tramas, mente cavilosa (II, IV, 338); multi-engenhoso (II, IV, 357-8); Laertíade poli-astucioso (II, IX, v. 309); herói poliardiloso (II, IX, 624); multilouvado, aquéia glória (II, IX, 673); Poli-engenhoso (II, X, 382-3); poliarguto (II, X, 400); multiastuto (II, X, 423); o pertinaz (II, X, 498).

xii Para comprovar, citamos alguns dos epítetos de Odisseu em HOM ERO, observando que nem todos estão contemplados na lista a seguir encontrados em Odisséia. Tradução de Carlos Alberto Nunes. 3. ed. São Paulo: Melhoramentos, 1960: ardiloso (I, 253; XXII, 115; XXIV, 172, 176); astucioso (I, 1; VIII, 474; XIV, 424; XV, 63; XVI, 5; XVIII, 51, 336; XX, 257, 283; XXII, 1, 238; XXIV, 490); astuto (II, 279; VIII, 18, 486; IX, 19-20; XXII, 202, 281, 390; XIII, 296-9); claro [na acepção de inteligente, inteligível] (III, 64; XII, 82); estremado [na acepção de dotado de discernimento] (IV, 328); manhoso [na acepção de astucioso, ardiloso] (V, 182-3); mente fecunda (II, 173); sábio (I, 48, 129; XXI, 379); solerte [palavra cuja significação é: astuto, sagaz, inteligente, manhoso ou velhaco] (IV, 763; V, 214, 354; VII, 168, 207, 240, 302; VIII, 152, 165, 412, 463; IX, 1; X, 330; XI, 354, 377, 488; XIII, 311, 382, 416; XIV, 191, 390, 439; XV, 340, 380; XVI, 201; XVII, 192, 353, 453; XVIII, 124, 365; XIX, 41, 164, 220, 261, 335, 382, 499, 554, 582; XX, 36, 168, 183, 226, 239; XXI, 274; XXII, 34, 60, 105; XXII, 170, 253, 320, 401, 490; XXIII, 247, 263; XXIV, 192, 302; XXIV, $330,356,406)$.

xlii Muitas personagens admitirão a inteligência, sagacidade e engenho de Odisseu. Citamos mais alguns exemplos dessa condição. Nestor, o mesmo sábio da llíada, testemunhará: “M as, quanto à astúcia, ninguém suportava confronto com ele, / que, na inventiva de ardis, sobrestava a qualquer companheiro" (III, 120-1). Calipso, a ninfa, reclamará: "És, em verdade, um manhoso, que nunca vãmente excogita!"/ Cheio de astúcias refletes e sabes dizer o que pensa" (V, 182-3). No Hades, Aquiles perguntará a Odisseu: "Filho de Laertes, de origem divina, Odisseu engenhoso, / que nova empresa, infeliz, mas ousada que as outras concebes?" (XI, 473-4). Ao retornar a Ítaca, Atena incentivará Odisseu a usar sua inteligência estratégica a fim de planejar o melhor modo de executar os juízos punitivos sobre os pretendentes: "Filho de Laertes, de origem divina, Odisseu engenhoso, / ora convém refletir de que modo mais fácil consigas / os pretendentes punir, que há três anos te a casa dominam / e tua esposa cortejam com dádivas grandes" (XIII, 375-8). 0 protegido da deusa responderá positivamente: "Ora vejamos um meio de como possamos matá-los" (XIII, v. 386). 
xliii Diz o narrador: "Ora começa de novo, e o cavalo de pau nos invoca, (...) esse, que o divo Odisseu com astúcia pôs dentro de Tróia, / cheio de heróis destemidos, que os muros sagrados saquearam" (Od, VIII, 492-5).

xliv Epítetos de Odisseu (in HOM ERO: 1960): engenhoso (V, 203; X, 401, 456, 488, 504; XI, 60, 92, 405, 473, 617; XIII, 375; XIV, 486; XVI, 167; XXII, 164; XXIV, 542); de grande inventiva (I, 83).

xlv Odisseu é apresentado como grande navegador, hábil no trabalho manual e de inteligência acima da média. Desde a llíada entram em cena essas características de Odisseu, aspecto que será explorado poeticamente em uma epopéia só dele - a Odisséia. Na llíada, a Odisseu o rei incumbirá a responsabilidade de capitanear o navio que levará em seu bojo, além dos demais marinheiros, a sacerdotisa de Apolo e os bois para o sacrifício de expiação junto ao deus iracundo. Homero, cuja origem denuncia-se nessas palavras [pois que pertencia a um povo amante da navegação] descreve a maestria com que Odisseu maneja a nau, detalhando cada movimento do capitão do navio: “(...) Logo Odisseu chega a Crisa / com a sacra hecatombe, e aporta ao mais profundo, / faz recolher as velas sobre a nave negra, / um lastro quase, e o mastro faz abater, soltas / as enxárcias. A remo, a nau balança a barra; / fora lançam a âncora, as amarras prendem; / fora saem todos mais - na areia o mar rebenta;" (II, I, 431-7). Depois de, com humildade e delicadeza, devolver a filha ao ofendido sacerdote, Odisseu participa dos rituais religiosos, o que suaviza a ira de Febo Apolo. Esse, por sua vez, envia ventos favoráveis para a viagem de retorno. 0 poeta de llíada descreve poeticamente [e na tradução de Campos, imagem sonoramente engrandecida] a embarcação singrando as águas e os trabalhos náuticos da volta: “(...) 0 mastro erguido, as velas pandas, / brancas, sopradas bem no centro, e em torno à quilha / que avança, as ondas - rastro púrpura - soando, / soando, enquanto a nau ao longo rasga a rota. / Chegando enfim ao amplo exército dos gregos, / arrastam para a terra firme a nave negra, / para a areia, no alto, e põem debaixo escoras." (II, I, 479-86).

xlvi Odisseu construirá a jangada para deixar a ilha de Calipso, sob orientação da ninfa. 0 narrador nos brindando com verdadeiro esquema de construção apresentado em detalhes, esquema so bre o qual vale a pena uma observação mais minuciosa. Primeiramente, note-se com que exati dão são listadas as ferramentas necessários à construção naval: "bipene de bronze, de fácil manejo", "enxó bem lavrada", em seguida, é admirável a relevância de um detalhe somente conhecido por profissionais experientes no manejo de madeira: a escolha das árvores cuja madeira, já devidamente seca, seria a mais adequada para suportar as intempéries da viagem. Depois, o corte e a limpeza: "Troncos derruba Odisseu; facilmente o trabal ho arremata. / Vinte, por tudo, abateu, e com o bronze dos galhos os limpa" (Od, V, 243-4). Notemos que tudo é medido e calculado, quais gráficos de um engenheiro. E a minuciosa tarefa é acompanhada pela prestativa Calipso - o que se configura no germe da ênfase sobre o trabalho em equipe: "mui habilmente os lavrou, as distâncias tomando com fio. / Trados Ihe trouxe, entrementes, a deusa preclara Calipso. / Todos, com eles, furou, ajustando, depois, uns aos outros, / encavilhando-os de jeito e travessas metendo a martelo" (Od, V, 245-8). Veja-se com que cuidado Odisseu calcula os dados para a construção de sua jangada: "Quanto experiente armador, que constrói um navio de carga, / largo e espaçoso, Ihe tira a medida da parte do fundo: / tanto em largura a jangada media do herói astucioso. / Põe-Ihe depois, um jirau, sustentando-o com vigas bastantes, / para, por fim, concluir a armadura com troncos ao longo / Mastro, também, levantou, adaptando-lhe no alto uma verga. / Leme aprontou e ajustou-lhe, porque fosse fácil guiá-la. / Para das ondas ficar protegida, em redor reforçou-a / com bem trançados cipós, pondo o lastro com muita madeira" (Od, V, 249-57). Observe-se acima o epíteto astucioso referindo-se à sabedoria, inteligência, argúcia, pois, empregando essa astúcia Odisseu constrói a jangada para deixar a ilha em que era mantido como prisioneiro de luxo pela ninfa que o desejava como esposo eterno. Odisseu costura a vela para a jangada: "Pano de linho Ihe trouxe, entretanto, a divina Calipso,/ para que a vela aprestasse. Com arte soube ele cortá-la, / nela prendendo, por fim, as adriças, escotas e braços" (Od, V, 258-60). Estamos diante de um Odisseu que corta, mede e costura o pano da vela, aptidão que se atrela às suas capacidades artísticas [as quais, por sua vez, se ligam à inteligência] manifestadas em outras áreas.

xlvii Outro elemento que contribuiu para moldar o caráter do menino Osman Lins foi a observação do pai em seu ofício. 0 pai de Osman, 0 alfaiate Téofanes da Costa Lins, era um profissional rigoroso e 
disciplinado. 0 contato com os tecidos, os meticulosos cálculos nas peças a ser costuradas, os riscos efetuados com esmero nos moldes e nas fazendas, fizeram com que Osman Lins incorporasse 0 pensamento metódico e o rigor que se tornaram tão peculiares em sua vida e na produção artística. Osman Lins escreveu em crônica homenageando o Dia do Alfaiate: "M eu interesse pelos alfaiates, admito, nasce da consciência de um certo paralelo entre o trabalho de escrever e 0 deles. Mas tem ainda outras raízes, mais pessoais e mais fortes: meu pai era alfaiate. Conhecida, na cidade pernambucana de Vitória de Santo Antão, onde viveu quase toda a vida, a Alfaiataria Lins. (...) Posso dizer que o vejo ainda, o brim estendido, com o auxílio de seus instrumentos, uma geometria cuidadosa e que lembrava certos desenhos dos meus livros escolares: os meridianos, o Zodíaco, as constelações" (LINS, Osman. O Evangelho na taba. Outros problemas inculturais brasileiros. São Paulo: Summus, p. 166-7). Note-se como o pequeno Osman fascinava-se com o mundo artesanal em que o pai laborava pelo depoimento a seguir, inserido no mesmo texto: “M anteve a linha sóbria das suas confecções (...) até encerrar atividades. Naquela época, eu já seguira os meus caminhos na vida, não era mais a criança que se inebriava com o cheiro das fazendas e que passava horas acariciando com as pontas dos dedos os pedaços de giz, captando para sempre aquela sensação de maciez". (idem, ibidem, p. 117).

Posteriormente, em entrevista a Carlos Acuio, para a revista M anchete e datada de 12.07.1969o autor explicita: “M eu pai era alfaiate. Um homem do povo. Eu sou um homem do povo. Minhas obras estão cheias de gente do povo. 0 herói de Lisbela e o Prisioneiro é um artista de circo. 0 de 0 fiel e a pedra nem sequer tem profissão definida. Seu amigo, Antônio chá, é um pobre de Deus, sem eira nem beira. São, neste sentido, obras populares (...) E ninguém pode imaginar a pulsação que sente um escritor quando escreve sobre aqueles que são a sua gente e parecem sustentá-lo, do fundo de seu desamparo" (idem, ibidem, p. 163).

xviii Odisseu mesmo construíra seu leito no palácio de Ítaca. E veja-se com que detalhes ele descreve o móvel, indicando, inclusive, a madeira empregada no trabalho: "Uma oliveira de espessa folhagem no pátio crescera; / como coluna era o tronco maciço depois de florido / À volta dele elevei minha câmara, até vê-la pronta, / toda de filas de pedras e um teto bem feito por cima. / Sólidas portas Ihe pus, trabalhadas com muito carinho. / Só depois disso cortei a folhagem da grande oliveira, / e o tronco todo lavrei, desde baixo, alisando-o com o bronze, / muito habilmente, tomando as medidas de tudo com fio, I para em um pé transformá-lo, da cama, furando-o com trado. / Desse começo construí toda a cama, até vê-la concluída" (Od, XXIII, 190-9).

xix A recorrência desse objeto marcador do tempo acontecerá de forma intensa em Avalovara, romance de Osman Lins, publicado em 1973, uma das linhas narrativas percorre a trajetória de Julio Heckethorn e seu relógio, uma espécie de símbolo de resistência aos modelos políticos de sua pátria.

'Osman Lins ficcionaliza a afetuosa interação que na infância mantinha com o tio, Antônio Figueiredo. Veja-se a emoção com que o escritor se recorda das atividades do parente: "Consertava os meus brinquedos, mesmo quando pareciam irreparáveis, jogava pião, soltava papagaios, fazia anéis para mim (além de outras coisas, era também ourives), soltava balões (...)" (ET, 189). Segundo as palavras de Osman Lins, Antonio Figueiredo parecia ser um homem inteligente e bastante curioso, tendo facilidade para criar peças de ourivesaria que vendia, assim como outras mercadorias e animais. Bernardo, como sabemos, é sua "imitação" no plano da realidade; embora como personagem, seja um misto de reminiscências literárias e nesse aspecto específico da engenhosidade, mais próximo do lado inventivo de Odisseu.

"Essa imagem do homem moldando a pedra será preciosa aos olhos de Osman Lins. Em entrevista ao Jornal do Comércio, de Recife, em dezembro de 1963 e publicada por Julieta de Godoy Ladeira no livro Evangelho na taba..., lemos a seguinte afirmação de Osman Lins, ao ser questionado so bre de que maneira a vida poderia amedrontá-lo: "Quero fruí-la: não governá-la. Mas, dentro do cabível, modelá-la, assim como Bernardo fazia com a mó em 0 fiel e a pedra. Essa modelagem é muito semelhante ao ofício de trabalhar com a pólvora. De repente, tudo pode explodir em nossas mãos e fazer-nos voar pelos ares. Mas se vencermos essa dança entre a manufatura e a explosão, que luminosi dades, que cores e desenhos haveremos de conseguir!" (ET, 131). 
lii HOM ERO. Odisséia. Tradução de Carlos Alberto Nunes. 3. ed. São Paulo: M elhoramentos, 1960, prudente (I, 87, VII, 168; XIX, 106; XX, 329; XXII, 115); prudentíssimo (XXII, 202; XXIV, 116).

liii Calipso, a ninfa, reclamará: "És, em verdade, um manhoso, que nunca vãmente excogita!"/ Cheio de astúcias refletes e sabes dizer o que pensa" (Od, V, 182-3). 0 comentário tanto faz referência à esperteza, quanto à prudência de Odisseu.

liv No banquete do rei Alcínoo, Euríalo diz ao hóspede (Odisseu): "Hóspede não te assemelhas a um homem que entenda de jogos, / como é costume entre as gentes, que folgam no seu exercício, / mas ao que folga viajar em galeras, de banco providas, / chefe de chusmas, que vive a mercar, tão-somente nos barcos, / só tendo em mente o seu lucro e o que possa trazer de tornada, / ganho com fraude. De fato, não tens a aparência de atleta" (Od, VIII, 159-64). Odisseu responde: "Bem se depreende que os deuses não cedem a todos os homens/ dons primorosos, ou seja na forma, no engenho, ou eloqüência/ "Este, na forma exterior, pode ser de aparência somenos, / mas recompensam-no os deuses com o dom da palavra; os que o vêem / sente prazer indizível, pois ele, com gesto seguro, / sempre se expressa modesto e se exalta da turba indistinta./ Se pelas ruas passeia, honrarias divinas recolhe./ Aos imortais outros são, na aparência exterior, semelhantes, / mas são privados seus ditos da graça, que os torna aceitáveis, / tal como tu: na aparência, sem mácula; doutra maneira / nem mesmo um deus te gerara; mas frívolo tens o intelecto" (Od, VIII, 166-77).

" Já llíada, Odisseu é chamado o eversor de cidades (destruidor) e na Odisséia, novamente é caracterizado com tal adjetivo (Od, IX, 504, 530; XVI, 442; XVIII, 356; XXII, 283; XXIV, 119).

Ivi $\mathrm{Na}$ Odisséia enxergamos essa característica em alguns momentos, como por exemplo, quando o herói se refere à riqueza de sua terra, citando, repetidas vezes, o "(...) solo fecundo/ de Ítaca”(Od, XXIV, 25960) e enfatiza favoravelmente o cuidado do lavrador ou do jardineiro, utilizando, como símbolos desses, o pai: "Vejo, meu velho, que tens muito jeito para essa labuta / de pomareiro, pois tudo está feito com senso e capricho, / sem que as pereiras e as vides, e os pés de oliveira, as figueiras / e as plantações de legumes pereçam por falta de trato" (Od, XXIV, 244-7). É no pomar que Odisseu aponta o sinal de reconhecimento, nesse encontro com o pai, citando as árvores frutíferas que Laertes lhe ofertara em criança, relembrando o nome de cada uma, informação transmitida carinhosamente pelo genitor. Nesse passo, percebemos a bela imagem do pai repassando a sabedoria dos antecessores ao filho, através da natureza, conduzindo sua criança a um conhecimento sobre a vida natural e se impondo como uma espécie de primeiro professor de ciências. 0 fato é que as lições e o terno amor para com o mundo em que viviam foram incutidos na mente infantil e nela fez guarida até a idade madura. Ainda sobre o trabalho na terra, o pragmático Odisseu, sempre dinâmico e atuante, condena [ou, pelo menos, se surpreende] os ciclopes por sua inércia e acomo dação, ao contar sobre sua estada entre esses gigantes: "O coração apertado, vogamos daí para diante./ Fomos, depois, aportar ao país dos soberbos Ciclopes, I destituídos de leis, que, confiados nos deuses eternos, / não só não cuidam de os campos lavrar, como não plantam nada. / Tudo Ihes nasce espontâneo, sem uso de arado e sementes" (Od, IX, v. 105-9). Odisseu diz, de forma crítica [repetimos, ao menos, segundo o que se apercebe pelo texto], que os ciclopes não trabalham, não lavram; esperam que a natureza lhes forneça as sementes, os frutos, para então os recolherem. Ao contrário dos ciclopes, veja-se a observação acurada de Odisseu sobre o país dos feácios, no quesito trabalho produtivo com a natureza: “Fora do pátio se encontra um jardim, logo ao lado da porta, / de quatro jeiras, cingido de todos os lados por sebes. / Árvores grandes se criam aí dentro, com viço admirável. / Vêem-se pereiras, romeiras, macieiras, de frutos esplêndidos, / mais oliveiras viçosas e figos mui doces ao gosto" (Od, VII, v. 112-6,). E são árvores frutíferas que produzem o ano inteiro. Uma vicejante horta também se vê, com canteiros bem estruturados. Ali se produzem legumes verdejantes, também, 0 ano todo. "Nelas jamais faltam frutos, nem nunca tais frutos estragam; / já no verão, já no inverno, durante o correr do ano todo, / Zéfiro faz que uns madurem, enquanto crescendo vão outros. / Seguem-se as peras, mais peras; maçãs a maçãs substituem; / vem depois da uva outras uvas, ao figo outros figos sucedem". Uma horta também é descrita: "Na parte extrema desse horto se encontram canteiros bem feitos / de variados legumes, que verdes estão 0 ano todo" (Od, VII, 117-28). 
Ivii Segundo Brandão, esse, citando entre suas palavras a especialista em assuntos greco-romanos, Maria Helena da Rocha Pereira, o termo abrange o "sentido de cumprimento do dever para com os deuses, os pais e a pátria". Conforme a estudiosa citada pelo dicionarista, piedade "(...) liga entre si os membros da comunidade familiar, unidos sob a égide da patria potestas, e projetada no pretérito pelo culto aos antepassados (...). Estabelecendo assim um vínculo afetivo entre os membros de uma família, a pietas alargava-se à divindade, e acaba por compreender também as suas relações com o Estado". Sobre a pietas entre os romanos, Maria Helena da Rocha Pereira ainda explica: "Está, pois, firmada nos sentimentos religiosos dos Romanos, que se sentiam protegidos pelos deuses Manes, Lares e Penates, e que pensavam que o dono da casa tinha o seu genius tutelar e que a esposa era protegida por Juno" (BRANDÃO: p. 243-4).

Iviii “Vamos, sem mais, ouvir arúspice ou vidente / - oniromante - que o sonhar provém de Zeus. / Que nos explique um tal rancor em Febo Apolo: / se de omissos nos culpa, em votos, hecatombes; / se the apraz receber (...) e nos poupar da peste". (II, I, 62-7).

lix Aquiles se justificará: "Até aqui não vim guerrear os Troianos, / (...) / A mim não roubaram gado, nem cavalos, / nem em Ftia (...) / devastaram plantios. / (...) viemos (...) salvar a honra em Tróia, / e a Menelau. (...)" (II, I, 152-60).

${ }^{1 x}$ Aquiles planeja retornar a Ftia, levando as riquezas que angariara em nome de Peleu, o rei da cidade. 0 pai tem planos de auxiliar o nobre filho a constituir família bem alicerçada: “(...) se retorno ao lar, I certo o próprio Peleu me buscará uma esposa / Na Hélade, na Ftia, entre as Aquéias há de sobra / filhas de paladinos da polis, princesas; / farei da que prefira minha esposa cara; / meu coração deseja há muito uma legítima / consorte, que comigo goze das riquezas / que Peleu conquistou. Pois nada como a vida" (II, IX, 396-401).

|xi “Não te comoves, Olímpico? Nunca Odisseu te foi caro / junto das naus dos Argivos (...) / oferecendo oblações? (...)" (Od, I, 60-3).

Ixii Depois de receber a visita de Hermes, pedindo que liberasse Odisseu para retornar a casa, Calipso vai em busca do herói e o encontra em estado de tristeza e saudades: "Dentro da gruta não foi encontrar Odisseu de alma grande, / que, como sempre, a chorar, se encontrava sentado na praia, / a alma desfeita em suspiros sentidos, e prantos e dores. / Lágrimas, pois, a verter, contemplava o infecundo oceano" (Od, V, 81-4). Sob a guarda de Circe, embora entre luxos e agrados, Odisseu reflete: "Nada tão doce, sem dúvida, pode existir, como a pátria / e os próprios pais, muito embora moremos num rico palácio, / longe, em país estrangeiro, distante dos que nos geraram" (Od, IX, 34-6).

lxiii Odisseu muito se admira da vida dos ciclopes: "Leis desconhecem, bem como os concílios nas ágoras públicas. / Vivem agrestes, somente nos cimos das altas montanhas, / em grutas côncavas, tendo cada um sobre os filhos e as esposa / plenos direitos, sem que dos demais o destino Ihe importe" (Od, IX, 112$5)$.

liv "Nunca te mostres benévolo para tua própria consorte, / como, também, não lhe contes os teus pensamentos completos, / mas uma parte revela e outra deixa que oculta Ihe seja" (Od, XI, v. 441-3).

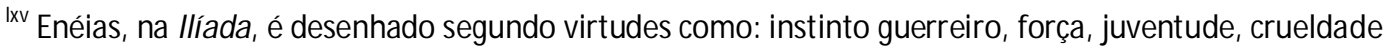
na guerra, liderança, impulsividade, proteção especial de uma divindade, orgulho, ira... Não parece que estamos falando de Aquiles? Nem mesmo Heitor, considerado o grande herói de Tróia e rival - por excelência - de Aquiles, apresenta tanta proximidade com o maior herói dos aqueus. Isso se torna visível, por exemplo, na inserção de uma mãe divina em ambos, e pela ira, que é o centro motor não somente de Aquiles, mas também de Enéias. Ambos se mostram antagonistas encarniçados, desafiandose constantemente. No famoso duelo dos dois, as palavras que uma dirigia ao outro eram propositadamente ofensivas. Todavia, Homero, insere em Enéias (movido pelas lendas ou não) uma característica que será realçada consistentemente por Virgílio, em sua Eneida- a piedade. Apesar de alguma demonstração de piedade da parte de Aquiles (no incidente em que Agamêmnon ofende 0 sacerdote de Apolo e o deus se vinga enviando peste mortífera, por exemplo, Aquiles demonstra 
aversão ao procedimento do rei, tanto pela falta de respeito ao idoso Crises, quanto pela ausência de temor do deus a quem o homem servia), o herói troiano, Enéias, é mais piedoso e se remete aos deuses em boa parte da narrativa. Um exemplo desse fato é o evento em que Aquiles ataca os troianos e lhes toma o gado. Nesse episódio, Enéias sensatamente foge, pois, em razão de sua piedade, percebera que não seria boa idéia enfrentar o grego, uma vez que, naquela empreitada, Aquiles agia guiado pela deusa Atena. E é à divindade máxima de gregos e troianos que Enéias atribui sua possibilidade de escape: "(...) mas Zeus guardou-me, dando-me ânimo / forte e joelhos velozes. Senão, com suas mãos / me domaria o Peleide, guiado por Atena," (II, XX, 92-3). Note-se que essa piedade está ligada ao relacionamento homem-deuses, pois, no episódio em que Enéias instiga os troianos a não devolver o corpo de Pátroclo, nota-se essa piedade, mesmo na atitude sacrílega aos olhos dos antigos. Enéias reconhecera o deus Apolo falando a ele por meio de um sábio arauto, Perifante. Ele lhe diz que Zeus quer os troianos vitoriosos e Enéias transmite essa nova aos troianos: "Agora, ao pé de mim, se faz presente um deus, / e diz que Zeus, mensurador excelso, está / conosco no combate." (II, XVII, 334-40).

A piedade de Enéias ressurge quando, na refrega da batalha, conclui que a má sorte dos troianos se deve em função da falta de piedade: “(...) Um deus, contra nós, / temo, encolerizou-se, por omissão, quem / sabe, de um sacrifício. Assusta a ira divina!" (II, V, 176-8). Enéias está sempre se referindo à relação dele - ou dos demais troianos - com os deuses. Ele é uma espécie de porta-voz dos homens à época de Homero, acreditando que todas as provas que acometem a humanidade advêm de sua insensibilidade aos reclamos divinos. Posêidon aconselhara Enéias a evitar Aquiles, para não morrer antes do tempo, mas os deuses o consideram uma espécie "títere" nas mãos do deus Febo Apolo. Os comentários preocupados dos deuses dão conta do paradoxo religioso: “(...) Inocente, por que deverá, I em vão padecer por culpa alheia? (...)" (II, XX, 297-8). A piedade de Enéias é lembrada. Ele é salvo, em parte por seu respeito e gratidão aos deuses: “(...) Ele sempre / doou aos deuses do vasto céu dádivas gratas." (II, XX, 298-9). E Poseidon[ que chama o guerreiro de "grande-coração"] propõe livrar Enéias da morte certa. É predito que a linhagem de Príamo desaparecerá da liderança dos italianos e que Enéias será o futuro rei. A semente da Eneida está lançada: "Ả linhagem de Príamo o Croníade detesta. / Agora, sobre os Tróicos, Enéias reinará / e os seus filhos e os filhos nascituros deles" (II, XX, 306-8).

Ixvi Seguindo o estilo de Homero, mas dele não abusando, Virgílio acresce ao nome de Enéias epítetos ligados a sua característica maior, a piedade: pio (I, 327 - IV, 585 - V, 36 - VI, $353-$ VII, 8, 150 - IX, 377 - X, 1053, 1109 - XI, 138, 225 - XII, 249); piedoso ( 455, 562 - VI, 12, 262 - VIII, 128 - XII, 529); filho tão piedoso (III, 733); pai cuidadoso (I, 967-70); filho extremado (1071-4); temente aos deuses (I, 822); padre (I, 877, 1048 - II, 2 - V, 188, 501, 517, 668 - VIII, 40, 174, 922 - IX, 243) grande (VIII, 552 - IX, 277, 333, 1137 - X, 220, 1116); bom (V, 1107); magnânimo (I, 387 - V, 24 - IX, 295 - XII, 235); rei justo: I, 822; herói Troiano (VIII, 803); herói Treuco (X, 790); maior capitão: (I, 822); melhor soldado: (I, 822). Na Eneida, o herói se apresenta como tal à gentil caçadora [Vênus disfarçada] com quem se depara antes de chegar ao reino de Dido, e que o informa sobre o caminho a seguir: "Sou o piedoso Enéias, que os penates, / Arrancados das mãos dos inimigos, / Na armada trago em minha companhia" (En, I, v. 561-9). Os penates que Anquises trazia, os quais foram encaminhados ao novo lar, por Enéias, corroboram a religiosidade do povo troiano fundador de Roma, condição perpetuada até Augusto. Apresentando-se à gentil caçadora que lhe aparece no caminho e que ele não sabia ser sua mãe, a deusa Atena, Enéias mesmo dirá sobre sua conhecida piedade: "Conhecido por fama além dos astros" (En, I, v. 561-9), dando ciência dos objetivos de sua viagem: "Pátria dos meus avós a Itália busco", complementando o dado sobre o direito à terra escolhida, por herança divina: "E descendente sou do sumo Jove"; acrescentado elementos informativos sobre o modo de sua locomoção: "Com vinte naus passei o mar da Frígia", inserindo a relevante proteção da mãe: "Da deusa minha mãe encaminhado" e, por fim, concluindo a auto-apresentação com o motivo fundamental de sua empreitada: "Aos decretos do céu obedecendo". Os companheiros de viagem ao comandante lembrarão a virtude maior de seu chefe: "(...) outro mais justo / Nunca existiu, / nem mais temente aos deuses" (En I, v. 821-3) ${ }^{\mid x v i}$ e acrescentarão outras qualidades ao herói, todas relacionadas ao seu fervor religioso e vocação submissa aos ditames divinos que redundava em proteção e direcionamento do Alto: "Rei nosso Enéias é, que a ninguém cede, / Pio e inteiro (...) / Se aura etérea o sustenta e o guarda o fado" (En, I, v. 571-3).

Ixvii Depois da visita de Mercúrio, cujo objetivo é lembrar a Enéias sobre sua verdadeira missão e recriminá-lo ostensivamente por dela se afastar, o herói fica atordoado com a advertência e 
atemorizado ante o que dizer a Dido: "Ai! Que fará? Ou como ousará agora / Ir falar à rainha enfurecida? / Que exórdio buscará? Veloz divide / Ora aqui, ora ali a fantasia" (En, IV, 412-5). E pensa num estratagema eficaz: "Entrada e ocasião em que mais branda / E meiga ela estivesse, buscaria, / E 0 modo mais astuto de falar-Ihe" (En, IV, 426-8). Todavia, Dido desco bre a dissimulação e se queixa:

"Tamanho crime, ó pérfido, esperaste / Poder dissimular e às escondidas / De meus reinos fugir? Nem o amor nosso, / Nem a mão que me deste, nem a triste / Dido, que vai morrer de crua morte, / Te detém? (...)" (En, IV, 446-9).

Ixviii Grimal aborda o fato de que os casamentos em Roma, à época de Virgílio, eram meros arranjos familiares, sem qualquer sentimento ou consulta da parte dos noivos: "Esta visão [do efeito da paixão como morte] adéqua-se ao espírito romano, que sempre olhou com desconfiança o desejo amoroso e empenha-se em fazer com que, no casamento, seu papel se reduza ao mínimo. 0 casamento destina-se a transmitir, de geração em geração, o 'sangue' da gens; deve garantir a perpetuação da cidade: são as 'núpcias justas'. A ternura quase não intervém, mesmo que, como é natural, possa aparecer e desenvolver-se à medida que a vida em comum e o nascimento de filhos teçam vínculos cada vez mais estreitos entre os esposos" (GRIM AL: 1992, p. 240-1)

lxix Confira-se a personalidade arredia de Virgílio em GRIMAL: 1992, p. 192. Estudos biográficos latinos em idiomas europeus, na bibliografia final deste trabalho.

Ixx Por exemplo, Bernardo tentará fingir serenidade durante a noite, o que perceberemos na conclusão de Teresa e expressa pelo narrador: “(...) ficou atenta à imobilidade do homem, à sua respiração calma sinais de repouso, com que ele procurava disfarçar suas insônias" (OFP, 75). Após o chamado de Miguel, com o intuito de sugerir as falsas vendas, mesmo contando tudo à esposa, Teresa, inferindo outros receios acalentados, pensará que o marido escondia os acontecimentos, bem como seus receios: "Que teria havido naquela tarde? (...) E que seria de ambos, se se cumprissem os ocultos medos de Bernardo? Ele sempre lhe escondia os maus sinais, as negras previsões. Mas que sabia ele?" (OFP, 73). Ao retornar do posterior chamado de Miguel, agora para a proposta para ajudar a matar o suposto rival, Bernardo mentirá sobre o motivo da viagem. Veja-se pelo diálogo entre os cônjuges. A mulher pergunta: "- Que é que ele queria?". E ouve a resposta evasiva: "- Eu mesmo não sei, minha velha" (OFP, 90). 0 narrador confirmará as suspeitas femininas: "Teresa rondava-0, sondava-0. Ele procurava esconder-Ihe as suas previsões" (OFP, 76).

Ixxi Nas Estâncias das Sombras, o herói vê Dido. A reação é de dor e culpa: "Lágrimas derramou e tais palavras / Com doce amor Ihe disse: (...) / (...) / Ai! A causa fui eu da tua morte!" (En, VI, v. 674-8).

Ixxii Na era republicana, o termo fides revestiu-se de uma roupagem social, política e jurídica, significando "confiança, garantia da palavra empenhada, fidelidade decorrente de um juramento", noção que a estudiosa portuguesa M aria Helena da Rocha Pereira ratifica: “Essa fides é um juramento que compromete ambas as partes na observância de um pacto bem firme. (...) Ora os Romanos consideravam-se - e eram considerados, segundo o testemunho de Políbio - como povo 'que respeita 0 seu dever, pela própria fidelidade decorrente de seu juramento' " (PEREIRA. Maria Helena Rocha. Estudos da história da cultura clássica. V. 2 Cultura romana. Lisboa: Fundação Calouste-Gulbenkian, 1982, p. 322, citada por BRANDÃO: 1993, p. 145). Observe-se o que explicita Brandão: "A dexterarum iunctio, a junção das destras, o aperto de mãos direitas é um ato religioso que pode, evidentemente, respaldar um compromisso político e jurídico. Com as destras entrelaçadas se fazia o iusiurandum, 0 juramento, de que resultava o foedus, o tratado de aliança, o pacto, cuja garantia era a fides, a absoluta 'fidelidade' ao que se estipulara" (idem ibidem, p. 146).

Ixxiii Nesse ponto, mais uma vez 0 escritor de 0 fiel e a pedra se remete à Bíblia, de forma indireta, nas palavras do padre Antonio Vieira, no sermão proferido no ano de 1645, na Capela Real. 0 objetivo central do sermão é discorrer sobre o grande amor de Cristo, o qual - lembra o padre - , já amava o mundo antes da encarnação, mas tal amor mais se intensificara ao experimentar as dores dos homens. Vieira se recorda de que se indagava sobre a razão de os "Sábios" gregos pintarem o "Amor" como um menino. 0 questionamento 0 levara à conclusão de que 0 amor era desse modo retratado porque durava pouco. Refletindo mais sobre 0 assunto, contudo, o padre chegara a novas conclusões e as 
apresentava aos ouvintes. Tal interpretação, diz ele, do amor fadado a pouca vida, não se sustenta porque há exemplos, na Bíblia, de amores eternos e cita dentre eles a amizade que unira Jônatas e Davi. E quem foram esses personagens? Davi foi o segundo rei dos judeus, mas, na meninice cuidava dos rebanhos de ovelhas da família e, como era comum naquele tempo, ausentava-se de casa por longos dias, a fim de oferecer boas pastagens aos animais. Nessas ocasiões, o menino pastor refletia sobre a vida e os mistérios do universo e se detinha a compor belos salmos que cantava acompanhando as palavras com o som de sua harpa. O sensível e meigo Davi, porém, sabia ser ousado e corajoso, enfrentando leoas e ursos que tentavam atacar o rebanho sob sua guarda. Também se ofereceu para lutar com o gigante filisteu, Golias, abatendo-o com uma pedra lançada de sua funda. Para sua surpresa, certo dia recebeu a visita do profeta Samuel que o ungiu rei a substituir o primeiro rei de Israel, Saul. Esse, ao saber do ocorrido irou-se sobremaneira, pois esperava deixar o trono para o filho Jônatas. Por conta disso, Saul se tornou um importante inimigo de Davi, perseguindo-o implacavelmente, mesmo tendo se tornado o jovem seu mais dedicado general - e genro, pois ele mesmo dera a filha ao valoroso guerreiro em recompensa por uma vitória bélica. Paradoxalmente, entre Davi e Jônatas desenvolveu-se uma terna amizade. 0 filho do rei submetera-se à ordem divina e aceitava sem objeções a transferência do trono a Davi. Até pedira ao cunhado e amigo proteção aos descendentes quando chegasse 0 momento da posse do cetro. Jônatas bem sabia o que poderia ocorrer com a casa real em caso de um golpe repentino; por isso fez com que 0 amigo jurasse benevolência a ele e aos seus descendentes. Depois disso, Davi mais severamente perseguido por Saul, o qual extravasava o ódio pelo sucesso do rival, pela predileção divina e também por causa da amizade com o filho. Mical, a filha de Saul, e Jônatas, protegeram Davi até quando foi possível. Em certa ocasião, Davi pede ao cunhado para interceder por ele junto ao rei e Jônatas aproveita para fazerem novo pacto de fidelidade: "E se eu ainda viver, porventura, não usarás comigo de beneficência do Senhor, para que não morra? Nem tampouco cortarás da minha casa a tua beneficência eternamente..." (I Samuel 20:14-15). Assim sendo, é um pacto de fidelidade que Jônatas solicita a Davi, com a anuência do último, em vista da amizade que ambos cultivavam em relação ao outro. E Vieira fala, então, do sentimento fraternal que ambos nutriam e da aliança que acontece no segundo momento: "A primeira vez que Jônatas se afeiçoou a Davi, diza Escritura Sagrada, que Ihe fez juramento de perpétuo amor: Inierunt autem David, et Jonatas faedus, diligebat enim eum, quasi animam suam. [E Davi e Jônatas fizeram aliança entre si, porque (Jônatas) amava-o como a sua própria vida - I Samuel 18:3]. Passaram depois disto alguns tempos de firme vontade, posto que de vária fortuna; torna a dizer o Texto, que Jônatas fez segundo juramento a Davi de nunca faltar a seu amor: Et addidit Jonatas dejerare David, eo quod diligeret illum.[ E Jônatas fez a Davi este novo juramento, pelo amor que Ihe tinha; porque o amava como a sua própria alma - I Samuel 20:17] (...) Quando Jônatas jurou a primeira vez, não sabia ainda o que era amar, porque o não experimentara; quando jurou a segunda vez já tinha larga experiência do que era e do que custava, pelo muito que padeceu por Davi: e era tão diferente o conceito que Jônatas fazia agora de um amor a outro, que julgou que 0 juramento do primeiro não o obrigava a guardar 0 segundo. (...) por isso fez juramento de novo amor. Não novo, porque deixasse de amar alguma hora mas porque era pouco o que dantes prometera, em comparação do muito que hoje amava" (VIEIRA: 2001, tomo 1, p. 353).

Ixxiv A frase "Uma só carne" em OFP, p. 249, faz alusão à bênção de Deus sobre o casamento de Adão e Eva: "Portanto, deixará o homem a seu pai e a sua mãe, e unir-se-á a sua mulher, e serão os dois uma só carne" Gênesis 2: 24 na BíBLIA DE REFERÊNCIA THOM PSON: 1996, p. 2. A expressão "fibras de uma corda", no mesmo ponto, faz referência ao texto de Eclesiastes: "M elhor é serem dois do que um, porque têm melhor paga do seu trabalho: Se um cair, o outro levanta o seu companheiro. Mas ai do que estiver só, pois caindo, não haverá quem o levante. Também se dois dormirem juntos, eles se aquentarão. Mas um só como se aquentará? Se alguém quiser prevalecer contra um, os dois Ihe resistirão. 0 cordão de três dobras não se quebra depressa." Eclesiastes 4: 9-12 (BÍBLIA DE REFERÊNCIA THOMPSON: 1996, p. 600)

${ }^{1 \times x v}$ Aquiles se preocupa com os guerreiros que morrem sem causa aparente. Ele sugere: "Vamos, sem mais, ouvir arúspice vidente / (...) que nos explique um tal rancor em Febo Apolo" (II, I, 62-4). Depois, fala brandamente a Calcas Testorides: “Calmo de coração, profere teu oráculo. / (...) ninguém, junto às naus côncavas, as mãos pesadas / lançará sobre ti (...)" (II, I, 85-90). 
Ixxi A reverência aos mortos, sabemos, fazia parte da religião greco-romana e imiscuía-se aos deveres de homens públicos. Os funerais envolviam jogos, banquetes e sacrifícios aos deuses. Os rituais duravam dias e o clima era de muito respeito aos mortos e sua honra. Na llíada encontramos descrição de funerais famosos, como o de Pátroclo e Heitor; na Eneida, o de Anquises. Parece um contra senso pensar que Aquiles tinha respeito aos mortos, pelo que fez com o corpo de Heitor; no entanto, devemonos lembrar que foi Pátroclo quem primeiramente descumprira o estatuto quanto aos mortos. Ao matar Sarpédon, também havia tentado espoliar o corpo: Ele dissera aos Ájazes: “Por terra jaz Sarpédon (...) / (...) Agora é espoliar-Ihe o cadáver, / ultrajá-lo, arrancando-Ihe as armas dos ombros" (II, XVI, 559-61). Depois disso, atirando uma pedra na direção de Heitor, Pátroclo acertara o rosto do condutor do carro do troiano, Cebríone. Em caindo o rapaz, Pátroclo zombara: "Que homem mais ágil, deuses! Que lindo salto! Se fora em águas piscosas a muitos / satisfaria, pulando da nau atrás de ostras" (II, XVI, 745-8). Suas palavras desrespeitosas parecem justificar a morte que se seguiria e os acontecimentos posteriores. Heitor luta pelo corpo de Cebríone e Pátroclo o puxa pelos pés, a disputa continuando até que os Dânaos arrebatam o corpo e o levam para longe dos dois guerreiros - os companheiros do grego espoliando o cadáver. Heitor intenta vingar-se cabalmente. Vejamos a seqüência de ações do filho de Príamo: assim que mata o amigo de Aquiles age de forma totalmente inusitada: "calcando o corpo morto e virando-o de face" (II, XVI, 863). Depois de chutar o corpo de Pátroclo, Heitor cobiça a armadura do herói, vestes confeccionadas pelos deuses e emprestadas por Aquiles, e as toma. Em seguida, arrasta o cadáver para um lugar em que melhor pudesse cortar-lhe a cabeça e jogar o resto aos cães: "Héctor, após tirar a armadura de Pátroclo, / arrasta-o e, com bronze afiado, quer dos ombros / decepar-Ihe a cabeça e arrojar-Ihe aos cães tróicos / o tronco. (....)" (II, XVII, 125-8), sendo impedido por Menelau e os demais gregos, os quais lutam para manter intacto o corpo de Pátroclo e depois, levá-lo a Aquiles. De posse do corpo, Heitor despe sua armadura e a substitui pela roupa de guerra de Pátroclo: “Longe da multilácrima batalha, estaca / e troca de armadura; (...) e enverga as armas / ambrósias do imortal Aquiles, dom dos numes / do Urânio ao pai Peleu, que ao filho as repassou" (II, XVII, 192-6). Essa última atitude de Heitor surpreende ao próprio Zeus, que, intimamente, censura o ato: "Zeus (...) viu-o, / de longe, revestir-se das armas divinas. / Move a cabeça e diz ao próprio coração: / 'Desventuroso! (...) Vestes armas ambrósias de imortal herói / que a todos mete medo. 0 bom e bravo amigo / Ihe mataste e, vilmente, da fronte e dos ombros / o espoliaste das armas; (...)' " (II, XVII, 198-208) e a divindade anuncia o castigo: “'(...) grande glória, entanto, será a tua recompensa, pois da luta a Andrômeda, / não tornarás, nem lhe trarás tão nobres armas! '". Heitor e outros guerreiros troianos tentam impedir 0 ato. Heitor ainda puxa o corpo com as mãos: “(...) Héctor / coruscante tentou puxar o morto, três / vezes, por detrás, pelos pés, e a brados altos / instava os Tróicos. Três vezes o rechaçaram / os árdegoimpetuosos Ájazes. (...)" (II, XVIII, 154-8). Mediante atos tão sacrílegos, Aquiles, em sua impetuosidade, retorna à guerra, mata Heitor e resolve agir de igual modo em relação ao corpo, em vingança por Pátroclo. Acaba exagerando em sua revanche, como o sabemos, profanando de forma mais intensa 0 cadáver, ao dar voltas e mais voltas com ele preso ao carro, ante o olhar atônito dos troianos.

|xxvii “(...) E uma ânsia de pranto surgiu / no herói, que recordou o pai. Pela mão toma / o velho e com brandura 0 afasta. Os dois choravam: / Príamo recordando Héctor (...) / recurvo aos pés de Aquiles; este, o pai e Pátroclo / pranteando. Os seus lamentos ressoavam na tenda" (II, XXIV, 507-12).

Ixxviii Note-se a gentileza com que Aquiles trata o rei Príamo: "Quando Aquiles saciou-se do pranto / e da ânsia que afligira seus membros e entranhas, / levantou-se do trono e fez erguer 0 ancião; / condoído de suas cãs, da barba e dos cabelos / brancos (...)" (II, XXIV, 513-6). Embora os modos irascíveis de Aquiles se manifestem mais uma vez ao perceber a pressa de Príamo, essa, decorrente dos temores de alguma provável reação intempestiva do anfitrião, na verdade, a irritação de Aquiles advém de um motivo aceitável: o guerreiro insistia com o rei em que permanecesse com ele porque havia mandado lavar, ungir e vestir o corpo de Héctor e desejava devolver o cadáver com as honras fúnebres de um grande comandante sacrificado por um ideal.

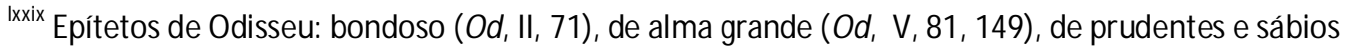
conselhos (Od, III, 162) [in HOMERO: 1960].

Ixxx Ao sentir que possivelmente fora enganado pelos feácios, Odisseu reclamará: "Zeus há de dar-Ihes a paga, ele que é protetor dos pedintes, / e que vê todos os homens e as faltas de todos castiga" (Od, XIII, 
213-4). Durante um dos banquetes dos pretendentes, Altínoo faz reprimenda a Eumeu por deixar entrar no palácio o mendigo (Odisseu disfarçado): "Qual o motivo, famoso porqueiro, de aqui nos trazeres / este mendigo? Não vês que já temos bastantes pedintes, / corja importuna e indecente, que vive a estragar-nos as festas?" (Od, XVII, 375-6). Odisseu, o mendigo do caso, diz: "Olha: também já morei, entre os homens, em casa opulenta, / muito feliz, onde esmola a qualquer peregrino, então, dava, / sem perguntar quem ele era e a que fora, até ali, esmolando" (Od, XVII, 419-21).

Ixxi “Por todo o tempo em que lá demoramos, jamais dissentimos, / eu o divino Odisseu, nos conselhos, assim como na ágora; / sempre, porém, com um só pensamento e conselhos prudentes, / dávamos nossa opinião aos Aqueus, só visando a vitória" (Od, III, 126-9).

Ixxxii “Um cão, que ali se encontrava, a cabeça e as orelhas levanta, / Argos, que pelo paciente Odisseu tinha sido criado / Mas, pela ausência do dono, ora estava largado de todo, / (...) De carrapatos coberto ali estava aninhado o cão Argos / Ao perceber Odisseu, que passava, entretanto, ao pé dele, / a cauda agita de leve, abaixando também as orelhas, sem que possível lhe fosse avançar ao encontro do dono / Este uma lágrima logo enxugou, disfarçando a mirada, / para que Eumeu não o notasse, dizendo-lhe logo em seguida: 'Que belo cão, caro Eumeu, neste monte de estrume se fina! / Forma admirável, de fato, possui (...)' / Ora ele está bem doente (...) / (...) indolentes criadas do pobre não curam" (Od, XVII, 291-319).

Ixxxiii Em relação ao cuidado de Enéias para com o filho Ascânio, note-se o desvelo implícito nas palavras do narrador: “(...) porque a mente / Sossegar Ihe não deixa o amor paterno" (En, I, 966-7). Os subalternos também reconhecem a atenção e bondade de seu chefe: "(...) outro mais justo / Nunca existiu, (...) / Nem maior capitão, melhor soldado" (En, I, 821-3). E note-se como Enéias administra conflitos entre seus soldados: "Não consentiu então o padre Enéias / Irem mais longe as iras (...) / Mas pôs fim à contenda; e ao fatigado / Dares salva, e o consola (...)" (En, V, 668-72).

Ixxxiv Bernardo se interessa pelo bem-estar de Miguel e sugere mudanças: "- Por que não muda 0 escritório lá para baixo?" (OFP, 27) "Deixe disso de estar pensando na morte. 0 senhor precisa distrairse, não passar toda a vida assim parado" (OFP, 30). Na suspeita de ser traído, acrescida de desejo de acabar com o rival, Bernardo também pal pita: "Se eu fosse o senhor, agüentava a mão. Só vai prejudicar-se mais, se liquidar o cabra (...). Se queria um conselho, eu dou: não mate o homem" (OFP, 88).

${ }^{1 x x x v}$ A relação de Aquiles e Tétis é pautada por afeto e grande interação. Sentindo-se profundamente magoado com 0 ato de Agamenon (tomar-Ihe Briseida), Aquiles invoca a mãe para 0 ajudar a resolver seu problema: “(...) Então à mãe / implora muitas vezes (...) / (...) E a mãe /augusta o ouviu (...) / (...) Então surgiu do mar / salino-cinza a deusa - uma bruma - e afagava / o filho em prantos. Disse: 'Por que choras, qual / a dor que à mente fere e te magoa? Conta,/ nada me escondas, filho. Quero partilhá-la. (II, I, 351-63). Schüler, remetendo a Fromm comenta sobre essa busca materna efetuada por Aquiles: "Aquiles continua só. Ao afastar-se dos seus companheiros, invocara a ajuda da mãe. Foi um ato de extremo desespero. Buscar a mãe significa voltar às origens, fugir do presente à proteção pré-natal, uterina, significa procurar a morte em sentido inverso" (SCHÜLER: 1972, p. 63). Aqui Schüler se refere à FROM M, Erich. Psicanálise da Sociedade. Rio de Janeiro: Zahar, 1963).

Ixxvi Bernardo se lamenta: “Em mim, tudo custa a crescer. Acho que vou perder a minha vida assim. 0 que sinto, o que procuro fazer, o que acho que vou fazer..." (OFP, 13).

Ixxxvii “Aquiles põe-se à parte, afasta-se chorando, / sentado junto ao mar salino-cinza, e olhava / ao longe as águas cor de vinho. (...)" (II, I, 349-51).

Ixxxviii Veja-se como a Odisséia descreve a ilha de Calipso: "Luxuriante floresta se estende por fora da gruta, / com numerosos amieiros e choupos e odoros ciprestes, / onde seus ninhos as aves constroem, de extensos remígios, / como corujas, falcões e assim gralhas de língua comprida / Prados macios em torno se viam, com aipo e violeta / cheios de viço. Até um deus imortal que ali viesse, por certo / se admiraria com tal espetáculo, na alma folgando" (Od, V, 63-75). 
Ixxix “Era noite; e por toda a redondeza, / Os lassos animais, aves e brutos, / Vencidos d'alto sono descansavam: / Quando ao frio relento o padre Enéias, / De tão funesta guerra perturbado, / Se recostou na ribanceira, dando / Tardo repouso aos membros/ "Eis qu'o mesmo / Deus do lugar, o velho Tiberino, / Ver se Ihe afigurou do ameno rio / (...) / (...) E desta arte / Lhe mitigou, falando, os seus cuidados: / (...) / "Não desistas da empresa; nem te assustem / Os ameaços da guerra: as iras todas" (En, VIII, 37-5, 59-60).

xc “Vênus, a quem o filho a dor magoa, / Colheu co'a própria mão no Ida Dicteio / Caule que vestem pétalas felpudas, / Embelezado de purpúreas flores, / Planta às montesas cabras não ignota / Quando a seta veloz no lombo sentem" (En, XII, 565-70).

xci Veja-se o que o poeta diz: "Acordo, subo em cima dum mirante, /E dali a escutar me ponho, atento; / (...) / Então, fora de mim, as armas tomo; / Para quê, nem eu sei: ímpeto ardente / Me leva a reunir algumas forças / E em socorro voar da fortaleza" (En, II, v. 484-6). Citamos o comentário de Grimal, sobre o episódio: “(...) agarra as armas, num movimento que, segundo nos diz, não domina por inteiro, e aí distinguimos sua humildade; ao invés de exaltar a coragem real então demonstrada, fala de desvario, de cólera, de um estado quase de pânico, de uma 'fuga para a frente', com (flutuando nesse oceano tempestuoso) trechos de lugares-comuns, como a idéia de que 'é belo morrer como soldado'. $\mathrm{Na}$ verdade, tem medo; refugia-se na ação e, sobretudo, na consciência súbita de ter-se tornado comandante dos poucos compatriotas que reúne para um contra-ataque desesperado" (GRIMAL: 1992, p. 221-2).

xcii Aquiles dirá que, embora dotado de grande beleza e forças físicas, não viverá muito (uma lástima, portanto): “Não vês como sou belo e vigoroso? (...) Mas sobre - / levam-te, e a mim, a morte e a Moira má. De manhã, de tarde ou no pino do dia, / alguém, na refrega (...), o meu sopro / vital há de tirar à lança, 0, vibrando 0 arco, / à flecha. (...)" (II, XXI, 107-10).

xciii Epíteto ligado à força física e moral: forte Enéias (En, XII, 957).

xciv 0 discurso que se preenche, em parte da fala e atitudes dos heróis e narradores clássicos, em 0 fiel e a pedra, parece encaixar-se no discurso bivocal de orientação únicaxiv , preconizado por Bakthin, um, já que Bernardo funde em seu caráter aspectos do caráter de Aquiles, Odisseu, Enéias e Vasco/lusitanos. (Conferir a terminologia citada in BAKTHIN: 1998, p. 200). Bakthin explicita esse tipo de discurso: “é inerente um traço comum, graças ao qual eles constituem uma variedade especial (...). Esse traço comum consiste em que 0 autor inclui no seu plano o discurso do outro no sentido das próprias intenções. A estilização estiliza o estilo do outro no sentido das próprias metas do autor" (idem, ibidem, p. 193).

xcV BAKTHIN: 1998, p. 190.

xcvi A llíada narra o interessante passo de Atena segurando Aquiles pelos cabelos: “Então, do céu, Atena desce. Enviou-a Hera, / dos braços brancos, que ama os dois, por ambos vela. / Por trás segura-lhe os cabelos louros, só / visível para ele; ninguém mais a vê" (II, I, 195-210). Atena responde ao questionamento de Aquiles so bre o porquê da interferência: "Descendo do alto céu, para acalmar-te a ira / (se acaso me obedeces), vim a mando de Hera, / (...) / Vamos, pára essa briga! Deixa em paz a espada!" (II, I, 195-210).

xcvii Ájax também reclama: “(...) Aquiles, no peito / asselvajou seu coração de ânimo grande / desacordouse, cruel, da amizade, dos seus / de todos quantos, sobre os mais da frota o honravam; / é implacável" (II, IX, 629-33), suplicando, depois: “(...) M odera o coração, / respeita esta tua casa e, sob o mesmo teto, / a nós, núncios dos Dânaos e, mais do que todos / os Aqueus, tidos por amigos teus, diletos" (II, IX, 6403). Pátroclo também censura: “(...) Tu, Aquiles segues / indobrável. Que essa ira que entesouras nunca / de mim se aposse, triste herói! Que legarás / aos pósteros, se não livrares os Aqueus / da ruína, da desgraça? Desumano! Não, / não foi teu pai Peleu, cavaleiro, nem Tétis, / tua mãe. 0 glauco mar talássio te gerou / e a escarpa, coração pedregoso. (...)"(II, XVI, 29-36). Conforme Aquiles relembra, os 
M irmidões o censuravam pela ira: "Cruel filho de Peleu, com fel tua mãe nutriu-te / insensível; reténs contra a vontade os teus / junto à naus; por que não voltar nos transmarinos / navios à casa, já que a bile má tomou / teu coração? (...)"(II, XVI, 203-7).

xcviii Odisseu recebe conselhos, sugestões, advertências e incentivo de outras personagens. Alcínoo 0 impele a narrar: "Conta, também, o motivo de tanto afligir-te 0 imo peito / ao escutares das desgraças de Tróia, dos Dânaos e Argivos" (Od, VIII, 577-8). Circe interfere no destino de Odisseu, com consel hos: "Filho de Laertes, de origem divina, (...) / (...) / e para o Hades escuro palácio, sem mais te dirige" (Od, X, 504,512 ) ordens: "Ora deixai de dormir, de entregar-vos ao sono agradável. / Vamos, que é tempo; já Circe potente ordenou que partíssemos" (Od, X, 548-9). Tirésias Ihe diz que se conseguisse controlar a avidez, encontraria êxito na jornada de retorno ao lar: "Se nenhum mal Ihes [às vacas de Hélio] fizerdes, cuidando somente da volta, / posto que muitos trabalhos tenhais, ainda haveis de ver Ítaca" (Od, XI, 110-1). Calipso: "Basta, infeliz, de chorar. Não consumas, assim, a existência; / (...) / Vamos! Apresta uma grande jangada (...) / (...) / para que possa levar-te através do brumoso oceano" (Od, V, 160-4). Atena Ihe diz, dentre tantos conselhos: “(...) Contém-te e suporta tudo isso" (Od, XIII, 307) e "ora, convém refletir de que modo mais fácil consigas / os pretendentes punir (...)"(Od, XIII, 376-7). E ante a possível morte de Fêmio, 0 aedo que divertia os pretendentes, Telêmaco suplica ao pai: "Pára! É inocente, meu pai! Que o teu bronze afiado o não fira. / Vamos salvar, igualmente, ao arauto M edonte (...)"(Od, XXII, 356-7).

xcix Enéias é assessorado pela mãe, o pai, "Salve! E quem quer que sejas, dar alívio / Te digna aos males nossos, e instruir-nos / Debaixo de que céu, ou a que parte / Do orbe arribado temos (...)"(En, I, 489-90). Quando em Cartago e, aparentemente, esquecido de sua missão, Enéias recebe a dura admoestação de Mercúrio: "Manda-me ele [Júpiter] trazer-te esta mensagem: / Que fazes tu aqui? (...) / Respeita o tenro Iulo e as esperanças / Do herdeiro teu (...)"(En, IV, 396-7). Dido: "Deixa esse pensamento! Eu to suplico" (En, IV, 465-6). “(...) Nem tu da deusa és filho, / Nem foi o Dárdano 0 autor da tua estirpe, / Mas do Cáucaso horrendo as duras rochas, / Pérfido! Te geraram, com seu leite / Te alimentou alguma tigre Hircana" (En, IV, 536-40).

' Efetivamente, não nos deteremos no aspecto do tempo em 0 fiel e a pedra, nem vamos adentrar para 0 âmago das polêmicas que envolvem 0 assunto, pois escolhemos fundamentar nossa pesquisa nos pressupostos bakhtinianos, embora aceitando o tempo psicológico em sua essência.

${ }^{c i}$ Bakhtin usa como exemplo o protagonista de Crime e Castigo, por exemplo, sempre a se entregar a angustiosos pensamentos, cujo tema era o duplo assassinato que cometera, bem como no que a mãe e a irmã escreveram sobre a vida no interior, Bakhtin diz que o monólogo interior, na verdade, é um microdiálogo com as personagens envolvidas (BAKHTIN: 1998, 75).

cii E tal condição parece assemelhar-se aos achados bakhtinianos: "A multiplicidade de vozes e consciências independentes e imiscíveis e a autêntica polifonia de vozes plenivalentes constituem, de fato, a peculiaridade fundamental dos romances de Dostoiévski. Não é a multiplicidade de caracteres e destinos que, em um mundo objetivo uno, à luz da consciência una do autor, se desenvolve nos seus romances; é precisamente a multiplicidade de consciências eqüipolentes e seus mundos que aqui se combinam numa unidade de acontecimento, mantendo a sua imiscibilidade" (BAKHTIN: 1998, 4).

ciii Ver GENETTE: 1972, 78-121; _-_-_: 1983, 15-22.

civ Ver GENETTE: 1972, 78-121.

${ }^{c v}$ Bakthin diz: "(...) o valor direto e pleno das palavras do herói desfaz o plano monológico e provoca resposta imediata, como se o herói não fosse objeto da palavra do autor mas veículo de sua palavra, dotado de valor e poderes plenos". (BAKHTIN: 1998, 3).

cvi Ver BIEDERM ANN: 1993, 239. 


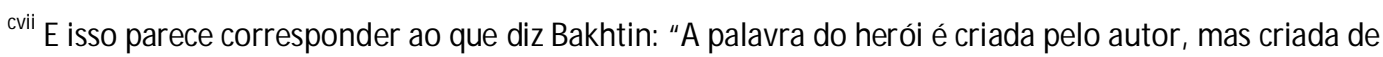
tal modo que pode desenvolver até o fim a sua lógica interna e sua autonomia enquanto palavra do outro, enquanto palavra do próprio herói. Como conseqüência, desprende-se não da idéia do autor mas apenas do seu campo de visão monológico" (BAKHTIN: 1998, 65).

cviii 'O thumos pode ter sido, em algum momento, um primitivo 'sopro' ou 'alma vital', mas em Homero ele não é nem uma alma (como em Platão) nem uma parte da alma. Ele pode ser definido, grosso modo, e em termos genéricos como um órgão de sentimento. Porém, ele goza de uma independência que a palavra 'órgão' não sugere, influenciado que somos pelos conceitos posteriores de 'organismo' e 'unidade orgânica'. 0 thumos de um homem Ihe diz, por exemplo, se ele deve comer, beber ou assassinar um inimigo. Ele 0 aconselha durante a ação, põe palavras em sua boca (...) 0 homem pode conversar com ele, com seu 'coração' ou 'barriga', quase de homem para homem. (...) Às vezes ele repreende tais entidades à parte (...); normalmente ele aceita seus conselhos, mas pode também rejeitá-los" (DODDS: 2002, p. 24).

cix Odisseu titubeia entre uma voz interna, o thumos, e outra: "Nesse momento ocorreu-me no peito magnânimo a idéia / de aproximar-me do monstro e sacar do meu gládio cortante, / para enterrar-lho no peito, onde o fígado se acha enco berto, / logo que o houvesse apal pado. Mas outras razões me tolheram / M orte haveríamos todos ali pavorosa, decerto" (Od, IX, 289-303).

"x Como exemplificação, ele recorre ao protagonista de Memórias do Subsolo: "O que o 'homem do subsolo' mais pensa é no que outros pensam e podem pensar a seu respeito, ele procura antecipar-se a cada consciência de outros, a cada idéia de outros a seu respeito, a cada opinião sobre sua pessoa. Com todos os momentos essenciais de suas confissões, ele procura antecipar-se a uma possível definição e apreciação de si por outros, vaticinar o sentido e o tom dessa apreciação e tenta formular minuciosamente essas possíveis palavras de outros a seu respeito, interrompendo o seu discurso com imagináveis réplicas de outros" (BAKHTIN: 1998, p. 52). 0 estudioso russo, cita, inclusive um dos momentos em que se percebe 0 diálogo interno do protagonista, o que transcrevemos em parte: "-E isto não é vergonhoso, e isto não é humilhante! - talvez me digais, balançando com desdém as cabeças. - Tendes sede de viver e resolveis questões vitais (...). Vós vos gabais de conscientes, mas vós apenas vacilais (...). É evidente que eu mesmo inventei todas essas vossas palavras. Isto também é do subsolo. Ali passei quarenta anos consecutivos prestando atenção, por uma fresta, a essas vossas palavras. Eu mesmo as inventei (...)" (BAKHTIN: 1998, p. 52). Sobre essa enxurrada de conceitos imaginados e replicados, Bakhtin completa: "O herói do subsolo dá ouvido a cada palavra dos outros sobre si mesmo, olha-se aparentemente em todos os espelhos das consciências dos outros, conhece todas as possíveis refrações da sua imagem nessas consciências; conhece até a sua definição objetiva, neutra tanto em relação à consciência alheia quanto à sua própria autoconsciência, leva em conta o ponto de vista de um 'terceiro' " (BAKHTIN: 1998, p. 52). O homem do subsolo estudara a visão de mundo de cada um dos seus possíveis avaliadores e formulara prováveis ponderações acerca de sua pessoa. Bakhtin, porém, constata o poder da personagem sobre tais julgamentos: "M as sabe também que todas essas definições, sejam parciais ou objetivas, estão em suas mãos e não Ihe concluem a imagem justamente porque ele está consciente delas; pode ultrapassar-Ihes os limites e torná-las inadequadas. Sabe que lhes cabe a última palavra e procura a qualquer custo manter para si essa última palavra, sobre si mesmo, essa palavra da sua autoconsciência, para nela não ser mais aquilo que ele é. A sua autoconsciência vive de sua inconclusibilidade, de seu caráter não-fechado e de sua insolubilidade" (BAKHTIN: 1998, p. 52). Bakthin ainda diz: "Revelar e representar o herói só é possível interrogando-o e provocando-0, mas sem fazer dele uma imagem concreta não abrange justamente aquilo que 0 autor se propõe com seu objeto" (BAKHTIN: 1998, p. 65).

cxi "O herói de Dostoiévski sempre procura destruir a base das palavras dos outros sobre si, que o torna acabado e aparentemente morto" (BAKHTIN: 1998, p. 59).

cxii "A autoconsciência enquanto dominante da construção da imagem do herói requer a criação de um clima artístico que permita à sua palavra revelar-se e auto-elucidar-se. Nenhum elemento de semelhante clima pode ser neutro: tudo deve atingir o herói em cheio, provocá-lo, interrogá-lo, até polemizar com ele e zombar dele, tudo deve estar orientado para o próprio herói, voltado para ele, tudo 
deve ser sentido como discurso acerca de um presente e não acerca de um ausente, como discurso da 'segunda' pessoa e não da 'terceira'. (...) Este [plano artístico] requer a total dialogação de todos os elementos da construção" (BAKHTIN: 1998, p. 64).

cxiii Os nomes das personagens também podem carregar imenso peso dialógico, pois que remetem a outros textos verbais ou não-verbais. Em obras de ficção, nomes de personagens e locais em que se dá a narrativa podem estar repletos de significado. Sobre esse assunto, Wellek e Warren, em seu livro Teoria da literatura, comentam: "A mais simples forma de caracterizar as personagens é pelos nomes deles. Cada 'apelação' é uma espécie de vivificação, animização, individuação" (WELLEK, WARREN: 1962, p. 276). Portanto, ao escolher um nome específico, 0 autor já está compondo sua personagem com dados qualificativos de seu caráter. 0 estudioso Vítor M. de Aguiar e Silva, em sua obra A estrutura do romance, discorre sobre a importância do nome da personagem: "O nome é um elemento importante na caracterização da personagem (...) funciona como um indício, como se a relação entre o significante (nome) e o significado (conteúdo psicológico, ideológico, etc.) da personagem fosse motivada intrinsecamente" (AGUIAR E SILVA: 1974, p. 34-5). Um exemplo dessa categoria está expressa no episódio da enunciação de Odisseu sobre seu verdadeiro nome (e caráter), depois de vencer Polifemo pela inteligência. Odisseu identifica-se de uma forma dúbia: “(...) Ninguém é o meu nome; Ninguém costumavam chamar-me / não só meus pais, como os mais companheiros que vivem comigo" (OD, IX, 366-70). Depois de ferir o gigante, diz que o Ciclope pode testemunhar que o "poderoso Odisseu" o vencera: "Ouve, Ciclope! Se um dia, qual quer dos mortais inquirir-te / sobre a razão vergonhosa de estares com o olho vazado, / dize ter sido o potente Odisseu, eversor de cidades, / que de Laertes é filho e que em Ítaca tem a morada" (OD, IX, 502-5). Odisseu parece estar aqui se pabulando, no entanto, percebemos mais uma referência ao caráter literário das lendas. Veja-se que ele diz "se algum mortal perguntar..." e não menciona os deuses ou os ciclopes, portanto, seu nome tem valor para as narrativas que os homens gostarão de ouvir - no futuro. Quando o gigante roga ao pai - Posidon - ele dá todas as indicações que Odisseu lhe dera: nome, caráter, filiação, pátria - algo impensável para um homem tão inteligente e astuto quanto o esposo de Penélope. A Odisséia é a epo péia que usa a onomástica como subtexto, espelhando a relevância que o nome de uma pessoa - e a reputação que o acompanhava tinha para os gregos. Vejamos o que - surpreendentemente - significa o nome do herói. E é o avô materno, Autólico, filho de Hermes, o deus "Iadrão", quem nomeia o neto e justifica tal escolha: "Filha querida e meu genro, ora o nome, que digo Ihe ponde. / Vim até aqui despertando inimigos por todo 0 caminho, / homens não só, mas mulheres, na terra de solo fecundo. / Ora Odisseu lhe chamai, 'que tem ódio'; há de ter esse nome" (Od, XIX, 406-9). Autólico era filho do deus Hermes, conhecido por roubar animais e objetos dos outros. 0 filho adquirira do pai a tendência, herdada ou imitada, de se apossar do que não Ihe pertencia e, por dilapidar ilicitamente o patrimônio das famílias, despertava ódio de todos por [daí, talvez, a explicação da menção de mulheres a persegui-lo]. Enfim, Autólico é parte das raízes de Odisseu e o herói, de certo modo, herdará do avô a astúcia para se safar das dificuldades. Odisseu também despertará o ódio de muitos seres - humanos ou divinos - como Polifemo e Poseidon e o ódio - numa acepção mais ampla do que simplesmente um sentimento de raiva - mas uma cólera que incita à ação, diferente da "ira" de Aquiles, que é paralisante. Bernardo também agirá tendo ódio dentro de si e se alternará entre o sentimento que engessa Aquiles e 0 impede de lutar e o que move Odisseu à luta incessante. A importância do nome de uma pessoa aparece também na digressão feita pelo rei Alcínoo, inserida na pergunta quanto ao nome do estrangeiro Odisseu: "Dize teu nome, e de como teu pai e tua mãe te nomeiam / na tua pátria, assim como os vizinhos, que em volta demoram. / Não há ninguém desprovido de nome na face da terra, / desde que nasce, quer seja de nobre prosápia, ou do povo" (Od, VIII, v. 550-3). A pergunta foi enunciada quando os nautas Feácios percebem as lágrimas do estrangeiro ao ouvir o canto de Demódo co. Evidentemente, o choro levava à conclusão de que os fatos narrados pelo aedo tinham a ver com a vida do visitante; portanto, seu nome seria o primeiro índice da ligação: nome e atos estariam inter-relacionados. Muito embora os nomes escol hidos para a obra literária sejam aleatórios, ou se tratem de uma homenagem a pessoas queridas (como se vê na dedicatória do livro 0 fiel e a pedra) esses nomes, como vimos, podem se encaixar plenamente no perfil das personagens dessa produção. Também aí reside o livre arbítrio do escritor, que é o idealizador de todas as nuances de um texto, o grande demiurgo que define os rumos de sua criação. Ele pode escolher nomes de pessoas e lugares que Ihe estejam à volta, preenchendo-os de um significado especial para sua narrativa. A carga metafórica de que se preenche os nomes das personagens em uma obra literária já era observada por Wellek e Warren (WELLEK, WARREN, 1962), como se segue: "A mais simples forma 
de caracterizar as personagens é pelos nomes deles. Cada 'apelação' é uma espécie de vivificação, animização, individuação". A economia de caracterização por meio da alusão literária é contemplada pela reflexão dos estudiosos, citando como exemplo M elville, com seus personagens Ahab e Ishamel. Não podemos nos esquecer de que M elville e seu romance 0 velho e o mar são citados como influentes na composição de 0 fiel e a pedra. (Entrevista concedida por Osman Lins para 0 Diário de 6 de abril de 1960, citada por IGEL, 1988, 49). Osman Lins também escolhe os nomes de seus personagens tendo em vista uma sub-escritura ficcional. Instigante é observar o significado dos nomes das personagens de 0 fiel e a pedra, e as possibilidades metafóricas que eles embutem. 0 nome Bernardo, como já apontou Marisa Simons, vem dos termos germânicos ber/bern que significa urso (ou guerreiro) e de hart/ardo, forte; portanto, urso forte ou guerreiro forte, o que remete à dubiedade do caráter do herói: as pessoas o vêem forte, visão que difere da que o personagem tem de si mesmo (já apontado por SIM ONS: 1999, p. 90). Bernardo tem como sobrenome Vieira Cedro, nos fazendo lembrar de que o primeiro termo tem como referência uma espécie de concha, e o segundo, é o designativo de uma árvore famosa pela firmeza diante dos vendavais. Assim, o nome completo do protagonista de 0 fiel e a pedra poderia assim ser traduzido: guerreiro reservado, introvertido e firme. Outros personagens foram nomeados com a intenção de expressarem, desse modo, um pouco de sua história individual e atuação na história coletiva de que é composto o romance. Quanto aos sobrenomes do protagonista, o primeiro - Vieira liga-se ao nome de um tipo de concha, remetendo ao caráter reservado de Bernardo, que, tal como uma concha é de exterior duro e hermético, mas delicado e frágil por dentro. Cedro é uma árvore que, por conta de seu tronco largo e forte e a copa frondosa e equilibrada, é famosa pela firmeza perante as tempestades, sendo um símbolo de firmeza em diversas civilizações, tal como o Líbano, onde a árvore é símbolo máximo. Regina Igel já havia apontado o caráter de simbologia na onomástica de 0 fiel e a pedra (IGEL: 1988, p. 48-59). Marisa Simons também se refere ao nome de Bernardo como significante (SIM ONS: 1999, p. 90). No Dicionário ilustrado de símbolos, de Hans Biedermann, lembra que na poesia hebraica judaica o cedro representa o justo, conforme é demonstrado nos versos "O justo cresce como um cedro do Ĺ́bano" do salmo bíblico. Também remete ao fato de que o cedro é formado de madeira imputrescível, não contaminável por fungos ou bactérias (BIEDERM ANN, 1993, p. 82- citando o salmo 92:13). A rigidez de cerne do cedro e o "forte" odor da resina que se exala da madeira cortada são mencionados na Eneida: "Ferido do machado soa o freixo, / Corta-se o pinho, que c'os céus entesta; / Não cessam de fender odorosos cedros / E os rijos robles com ferradas cunhas, / De levar olmos nos gementes carros" (En, XII, 177-81). Sendo essa epopéia a grande base para a reescrita do romance, poder ter havido certa influência os versos acima na escolha de uma parte do sobrenome do protagonista.

${ }^{\text {cxiv }}$ Particularmente na llíada, Homero insere, às vezes, determinadas façanhas do herói sendo cometidas sob a força do menos, certo ardor, ou paixão, uma 'intervenção psíquica' que, em geral, vem ao herói em resposta de uma prece. Dodds informa: "comunicação de poder de deus ao homem". "Não se trata de força física; nem mesmo de um órgão (uma faculdade) permanente de nossa vida mental, como o thumos ou o nous [inteligência, entendimento, consciência]. É muito antes, um estado mental, como a ate. Quando um homem experimenta menos no seu peito, ou sente 'inflar pungentemente as narinas' ele está cônscio de um misterioso acesso de energia; a vida nele se torna forte, e ele pleno de confiança e impetuosidade. (...) No homem, ela é a energia vital, a 'vivacidade' que nem sempre vem ao nosso chamado, mas que oscila misteriosamente, e caprichosamente (como costumamos dizer) em todos nós. Mas para Homero, não se trata de um capricho, e sim, do ato de um deus que 'aumenta e diminui conforme sua vontade a aretê de um homem (sua potência de luta)". (DODSS, E. R. Os gregos e o irracional. Tradução de Paulo Domenech Oneto. São Paulo: Escuta, 2002, p. 16-7). Dodds cita, em nota 45, de fim de texto, Ehnmark e Bohme como dois dos explicitadores do termo (idem, ibidem, p. 30). Já na Odisséia, 0 autor emprega 0 termo menos para o sentimento de coragem moral que um deus instila no herói (como no caso de Telêmaco, inspirado por Atena). Fêmio, o cantor, também admite que um deus Ihe insufle poder criativo, inspirando canções.

${ }^{c x v}$ A figura do daemon aparece no passo que narra 0 ataque a Polifemo, instilando coragem: “(...) ao redor se postaram / meus companheiros; coragem nos deu qualquer grande demônio" (Od, IX, 380-1). Ou alterando a percepção e discernimento: "Ama querida, do juízo privaram-te os deuses, que podem / o entendimento turvar a quem quer que mais senso possua, / e o uso emprestar da razão a quem dela se mostre privado" (Od, XXII, 11-2). Quando o herói manifesta uma idéia brilhante ou infeliz, no caso de 
Telêmaco, ao mudar as armas de lugar, antes da matança dos pretendentes: "Outra objeção mais valiosa lançou-me no espírito o Crônida" (Od, XIX, 10) e os mesmos pretendentes, referindo-se ao plano de Penélope, de tecer de dia e desmanchar o trabalho à noite: "(...) os deuses celestes / Ihe inspiraram. (...)" (Od, II, 124-5). Dodds ressalta o fato de que Homero se remetia a deuses antromorfizados, como Atena e Zeus e não a anônimos daemons. E se insere tais entes no discurso de suas personagens, está sendo 'realista', fazendo suas personagens falarem com as pessoas que crêem em avisos sobrenaturais o fazem (DODSS, E. R. Os gregos e o irracional. Tradução de Paulo Domenech Oneto. São Paulo: Escuta, 2002, p. 19).

cxvi Dodds, em seu Os gregos e o irracional, esclarece que o rei agiu seguindo os ditames da comunidade, não se eximindo da responsabilidade civil diante de seu ato involuntário. 0 estudioso salienta a dificuldade que o poderoso rei teria de quebrar o orgulho ao reconhecer sua culpa: "Tivesse ele agido por vontade própria, não seria nada fácil admitir o erro; mas tal como a situação se apresenta, ele pagará por seus atos. Juridicamente sua posição seria a mesma em ambos os casos, pois a justiça grega dos primórdios não se interessava pelas intenções - era o ato que importava" (DODDS, E. R. Os gregos e o irracional. Tradução de Paulo Domenech Oneto, São Paulo: Escuta, 2002, p. 11). E sobre as incongruências da noção de destino - um conceito religioso - em Homero, Dodds mesmo diz: "Para os estudiosos clássicos, os poemas homéricos parecerão um mau lugar para procurar algum tipo de experiência religiosa. 'A verdade é', diz, por exemplo, o professor Mazon, em um livro recente, 'que nunca houve um poema menos religioso do que llíada'. Isto pode ser visto como um exagero; mas reflete uma opinião que parece amplamente aceita" (MAZON. Introduction à I'lliade, p. 294, citado em DODSS, E. R. Os gregos e o irracional. Tradução de Paulo Domenech Oneto. São Paulo: Escuta, 2002, p. 10). E Lalande, sobre o assunto específico da noção de destino, nos oferece uma luz: "Este termo é mais poético do que filosófico. Constitui uma espécie de personificação da fatalidade ou dos acontecimentos fatais (nos diversos sentidos da palavra)" (LALANDE, André. Vocabulário técnico e crítico da filosofia. Tradução de Fátima Sá Correia, Maria Emília V. Aguiar, José Eduardo Torres, Maria Gorete de Souza. São Paulo: Martins Fontes, 1999, p. 243). Assim, tendo como base a llíada, só podemos concluir que Homero está dando um passo à frente de seu tempo, em direção à noção do homem como sujeito responsável que se verá na Odisséia. Brandão se aventura a concluir: "Na literatura grega, particularmente na llíada (...) ora Zeus se identifica com a Moira, ora parece que até poderia modificá-la, se o quisesse, ou simplesmente a mais temível das divindades paira soberana acima do pai dos deuses e dos homens (...)" (BRANDÃO, Junito de Souza. Dicionário mítico-etimológico da mitologia e da religião romana. Petrópolis: Vozes/ EDUNB, 1993, p. 130). Por fim, fica a afirmação de Homero posta nos lábios de Helena, quando essa se dirigia a Heitor - tudo não passa de criação poética: “(...) Tens / o coração num círculo de mágoas, por / causa desta cadela que eu sou e do louco / Páris, a quem Zeus fado sinistro impôs, para / que ambos, sejamos tema dos vates vindouros" (CAM POS, Haroldo de. Ilíada de Homero. São Paulo: Mandarim, 2002, v. I, canto VI, v. 354-8, p. 253).

cxvii E Agamenon, 0 arrogante, desafiador atreide, o que assumia veementemente a autoria de seus atos, depois de todos os problemas causados pela sua insistência em se apoderar da cativa de Aquiles e, conseqüentemente, provocar um imenso problema para gregos e troianos, isentar-se-á de culpa, atribuindo seus atos a ate (louca paixão advinda dos deuses): “(...) Não sou culpado, / mas Zeus, a M oira, e a negronoctâmbula Erínia; / na ágora, eles cegaram-me os siso, funestos / Mas, que fazer? Perpassa um nume e perfaz tudo: / Ate, a filha maior do pai Zeus, atroz, multi- / enganosa. Pés lépidos, não pisa a terra; / anda sobre a cabeça dos homens e ao cabo / os arruína; um depois do outro, ela os burla e enreda" (II, XIX, 86-94). Acerca desse passo, Dodds comenta o fato de que moira é o Destino , as Erínias, reforçadoras do destino, e Zeus, o "agente mitológico que o poeta concebe no caso como 0 primeiro motor" (DODSS: 2002, p. 14). Dodds não acredita que a idéia da moira devesse ser personificada, pura e simplesmente, em toda a llíada, pois "E no que concerne à Moira, creio que ela é mencionada porque as pessoas, diante de algum desastre inexplicável, o tomavam como parte de um 'Iote' ou de um 'quinhão' que Ihes cabia, sem buscar um significado mais profundo do que o de não poder compreender o que ocorria. Porém, uma vez que o fato aconteceu, ele evidentemente 'tinha que ser'. Muitas pessoas ainda falam dessa maneira, sobretudo em se tratando da morte (...)" (idem, ibidem, p. 14-5). Dodds ainda prossegue: “O máximo que podemos dizer é que tratando a 'porção' que lhe cabe como um agente - por considerá-la como responsável pelo que acontece - Agamenon está dando 0 primeiro passo na direção de uma personificação" (idem, ibidem, p. 15). Agamenon, candidamente, se 
exporá ao julgamento legal da coletividade, atribuindo seus atos à divindade, mas pagando o ônus referente: E se as ações eram atribuídas a ate, provocada pelos deuses, outra doutrina se impunha: a de que o destino de cada pessoa estava traçado desde seu nascimento. Na disputa de Aquiles contra Enéias, sendo esse último ajudado por Febo Apolo, Hera diz: “(...) Mal nenhum padeça Aquiles / hoje, ao menos, das mãos dos Tróicos; amanhã, / sofrerá, sendo o caso, tudo quanto o acaso, / desde o berço, Ihe urdiu com fio de linho. (...)" (II, XX, 126-9)? Aquiles dirá a Príamo que não adianta chorar, pois os deuses é que determinam os destinos: “(...) Assim os deuses urdem o fadário / dos infaustos mortais: um viver agoniado" (II, XXIV, 525-6).

cxviii Para os gregos antigos o destino (em suas variações polissêmicas acaso, fado, sorte, fortuna) grosso modo - era a personificação da fatalidade, um poder complexo, não muito claro a todos, e do qual não se conseguia fugir. Durozoi e Roussel explicitam sobre o Destino: "Poder misterioso e personificado que, no pensamento antigo, com a tragédia grega (...) rege o devir universal, inclusive 0 curso da história humana, sem que possa intervir a vontade ou a previsão do homem" (DUROZOI, ROUSSEL: 1993, p. 130). No entanto, Homero apresenta tríplice possibilidade quanto ao destino: 0 acaso/ sorte determina tudo, sendo o destino de cada um pré-determinado; o destino pode ser alterado dependendo dessa ou daquela ação humana, como no caso de Aquiles; o homem é responsável pelos seus atos. Na llíada, um exemplo do pensamento de que o acaso/ sorte é que determina os rumos da humanidade aparece no comentário de Hera à Atena, depois da irada advertência por parte de Zeus, a que não entrassem, elas mesmas, no campo de batalha e nem lutassem a favor dos gregos, como estavam planejando: “(...) Não vale / a pena que enfrentemos, por mortais, o Pai. / Que uns morram, que outros vivam, é coisa do acaso" (II, VIII, v. 427-30). Outro exemplo dessa visada ocorre na maneira como Aquiles, ao final da narrativa épica justifica 0 ato de Agamenon que Ihe trouxera tanto desagrado: “(...) Tonto / que Zeus sapiente fez demente. (...)" (I, IX, 377-8). Embora, como vimos, o mais forte dos guerreiros aqueus tenha esbravejado contra o rei atreide pelo fato de esse Ihe tomar Briseida (bem como em tantas outras atitudes inconvenientes suportadas estoicamente durante o período da guerra contra os troianos, mas atiradas ao rosto de Agamenon, perante todos os gregos reunidos em assembléia), ao final da epopéia, Aquiles considerará Agamenon mero títere nas mãos de Zeus. No segundo caso, o destino poderia ser flexível. Fênix, por sua vez, expõe a Aquiles o fato de que até os deuses eram "fflexíveis" (II, IX, 497-8) e Aquiles, efetivamente, goza desse privilégio, condição o que a mãe divina Ihe transmitira: “(...) Pés-de-prata, a deusa Tétis, madre, / me avisou: um destino dúplice fadou-me / à morte como termo (...)" (II, IX, 410-6) e explica: “(...) Fico e luto em Tróia: / não haverá retorno para mim, só glória / eterna; volto ao lar, à cara terra pátria: / perco essa glória excelsa, ganho longa vida: / tão cedo não me assalta a morte com seu termo". Ao tomar ciência do desejo de Aquiles de se bater com Héctor e resgatar as armas apreendidas pelo tróico, Tétis, em lágrimas, dir-Ihe-á: "M oira breve a tua, filho, já que assim o decides. / Héctor morrendo, o Fado há-de querer-te morto!" (II, XVIII, 95-6). Na terceira visada, a da responsabilidade de cada um sobre os seus atos, ela se mostra, dentre outros momentos, na enxurrada de impropérios na direção de Agamenon, culpando-o por suas falhas de caráter, por seus atos. No final de sua epopéia, Homero inserirá o conselho de Odisseu a Agamenon, palavras que quase invalidam o aspecto de determinação divina nos atos do rei: "E tu, Atreide, no porvir, sê mais equânime / para com os outros. Não deslustra um basileu / desculpar-se ante alguém a que ofendeu primeiro" (II, XIX, 182-4). Por fim, fica a afirmação de Homero posta nos lábios de Helena, quando essa se dirigia a Heitor - tudo não passa de criação poética: "(...) Tens / o coração num círculo de mágoas, por / causa desta cadela que eu sou e do louco / Páris, a quem Zeus fado sinistro impôs, para / que ambos, sejamos tema dos vates vindouros" (II, VI, 354-8).

${ }^{c x i x}$ Na Odisséia percebemos a reiteração da crença no Destino como um poder personificado que rege a sorte dos homens. No banquete de Alcínoo, o aedo Demódoco narra em seu canto, referindo-se à Tróia e ao incidente do cavalo contendo guerreiros em seu bojo: "pois o Destino assentara que fosse assolada a cidade" (Od, VIII, 511). Calipso diz a Odisseu: "Não é dos Fados que morra distante dos que Ihe são caros, / pois Ihe reserva o Destino rever os amigos, e a casa / de alto telhado voltar, assim como o torrão de nascença" (Od, V, 113-5). M uitas vezes nos depararemos com o Destino acompanhado da Morte, assim personificados, sendo uma espécie de forças complementares, e em várias ocasiões, tendo seus designativos acrescidos de adjetivos. Como por exemplo: "Todos os que conseguiram fugir da precípite M orte / já se encontravam na pátria, da guerra e do mar, enfim, salvos / menos um só [Odisseu]" (Od, I, 11-3). Odisseu contará sobre 0 ataque aos cíconos e sua revanche: "De cada nau pereceram seis homens 
de grevas bem feitas; / todos os mais escapamos da M orte e do triste Destino" (Od, IX, 60-1). Paradoxalmente, mesmo estando o destino traçado, coisas podem acontecer contra esse desenho. Odisseu quase perde sua vida, "contra o Destino", não fosse a "inspiração" divina - a deusa protetora o instiga a nadar paralelamente à costa e escolher com cuidado o melhor lugar para aportar: "E contra 0 próprio Destino, teria o infeliz perecido, / se inspiração não lhe desse a donzela de Zeus de olhos glaucos" (Od, V, 436-7). Quanto à graduação de poder do Destino em relação aos deuses, duas perspectivas aparentemente opostas são explicitadas por Atena. 0 Destino/M orte é mais forte do que os deuses. Esses tentam impedir que o homem pereça, mas são impotentes para tanto. Mentes/Atena diz a Telêmaco: “Mesmo de longe é mui fácil a um deus socorrer qualquer homem. / (...) / Mas para todos a Morte é uma só, nem conseguem os deuses, / inda ao mais caro dos homens, sequer defendêIo, ao ser ele / pelo Destino exicial alcançado, da M oira funesta" (Od, V). Os deuses podem impedir a concretização do Destino. Atena obstrui o curso dos furiosos ventos enviados por Posido à jangada de Odisseu a fim de poupar da morte o seu protegido: "E da Morte e do negro Destino escapasse [Odisseu]" (Od, V, 387). Ou ainda, uma terceira condição: os deuses também podem condenar um ser humano à morte, entregando-o ao Destino. Tendo tomado ciência das mortes de Agamenon, Egisto e Clitemnestra, Telêmaco diz a M entes/ Atena: "(...) o que é certo é que os deuses eternos / os condenaram à morte, entregando-os ao escuro Destino" (Od, III, 241-2). Por outro lado, na Odisséia, ainda se vê lastros da crença - tão amplamente exposta na llíada - de que os deuses regem os destinos dos seres humanos. Alguns exemplos nos vêm e os citamos a seguir. Odisseu diz a Antínoo que Zeus inspirara o desânimo: "(...) Nos meus companheiros o Cronida / fulminador o desânimo inspira, ninguém se atrevendo / a resistir, que por todos os lados a Morte ameaçava" (Od, XVII, 437-9). Os pretendentes dizem que a idéia que Penélope tivera [de enganá-los, tecendo e desmanchando o trabalho, durante três anos] fora inspirada pelos deuses "intento que os deuses celestes / no coração lhe inspiraram" (Od, II, 124-5). Nestor, o sábio rei visitado por Telêmaco, diz que os deuses convenceram a esposa de Agamenon a traí-lo: "Quando porém, a vontade dos deuses a fez submeter-se [a Egisto]" (Od, III, 269). Telêmaco, ao relatar acerca da viagem até Esparta, diz à mãe que os fatos desencadeados por Helena aconteceram por determinação divina: "Lá pude Helena admirar, por quem tanto os Troianos e Aquivos I digladiaram, que tudo se deu por desígnio dos deuses" (Od, XVII, 118-9). Penélope dirá o mesmo a Odisseu, ao justificar sua desconfiança durante a revelação da identidade do mendigo/esposo - nem mesmo Helena seria acolhedora numa tal situação e explicita: “Um deus, sem dúvida, a fez praticar tal ação vergonhosa, / sem que tivesse, realmente, no espírito a cul pa funesta / premeditado, que a origem nos foi de tão grande infortúnio" (Od, XXIII, 222-4). Também de forma antagônica à idéia de que os deuses comandam as ações dos homens, apresenta-se outra: os deuses agem, mas o projeto deles não acontece. Veja-se o exemplo do atraso de Odisseu em regressar ao lar. Os deuses bem que teceram 0 tempo de Odisseu chegar, mas isso não ocorre. Ao contrário, Odisseu torna-se um requintado prisioneiro da luxuriante Calipso, é o que nos conta o narrador no início da epopéia: "Mas depois que, no transcurso do tempo, foi o ano chegado, / que os próprios deuses teceram, de a pátria alcançar finalmente, / Ítaca, nem mesmo assim conseguira fugir aos trabalhos" (Od, I, 16-7). E esse insucesso entristecia os observadores so brenaturais: "Lastimavam-no todos os deuses, / com exceção de Posido $(. .) ".(O d, I, 19-20)$; isto é, os deuses lamentavam que os atos de Odisseu [mais precisamente um deles 0 ataque ao filho de Posido] 0 impedissem de concretizar seus sonhos de retorno à pátria. Portanto, nem mesmo com o destino "tecido", esse destino se realiza, pois ele depende da ação do herói. Mais à frente, 0 destino será novamente interrompido com o atos dos companheiros do herói: soltando os ventos de Éolo; alimentando-se do gado de Hélio.

${ }^{c x x}$ Para os latinos, anteriores a Virgílio, Fatum era o deus do Destino e seu nome liga-se à raiz do verbo falar, contar, predizer, fari. Fatum foi gradualmente incorporado as divindades gregas Moiras, Parcas e Sibilas (Conferir em GRIM AL: 2000, p. 164 e BRANDÃO: 1993, p. 129-30).

Virgílio foi seguidor do epicurismo de Sirão, um mestre grego radicado em Roma. 0 poeta de Mântua morou durante um período no recanto em que o sábio ensinava os discípulos, em meio às hortaliças e flores. Evidentemente a atitude filosófica epicurista permeou os primeiros escritos de Virgílio. Epicuro, filósofo grego entre os anos 341-270 a. C. também ministrava suas aulas numa escola que era uma espécie de jardim ao ar livre. 0 sistema filosófico de Epicuro, em grande parte, fundado em Demócrito, dentre outras coisas, sugeria como condição para a felicidade, certas atitudes, tais como: busca de refúgio e segurança na natureza, indiferença ante a morte, ausência de dor como limite do prazer. 0 sábio propunha ainda um meio para se alcançar a ataraxia - o estado de purificação de qualquer 
angústia - abandono dos prazeres supérfluos, vida frugal - ascética. Epicuro identificava dois tipos de desejos: os necessários - objetivando o bem moral, como a amizade - e os não necessários, que podem ser descartados sem sofrimento. Para Epicuro a religião é causa de angústia, por exemplo, os gregos tinham receio dos trovões porque achavam que Zeus estava irado. Para o sábio, a ciência poderia explicar os fenômenos da natureza e acalmar os nervos dos crédulos. Epicuro segue a linha de Demócrito e não acredita em um Deus criador e mantenedor, mas não nega a existência dos deuses, embora considere que esses nunca se ocupam com o nosso mundo. Na opinião de Epicuro, o ser humano não deve temer os deuses, nem pedir nada deles. Os deuses teriam a forma humana, seriam seres felizes, sábios, vivendo em harmonia entre si e dialogando em grego. Epicuro também defendia, dentre outras coisas, que os acontecimentos advinham de uma espécie de destino cego que produzia todas as causas aleatoriamente, cabendo aos homens a liberdade de exercer domínio sobre seus caminhos (GRIM AL, 1992, p. 172). Epicuristas latinos incorporarão essa idéia do destino cego a Fatum. Virgílio, em seus poemas, prega a possibilidade da existência do grande e, de certa forma, indiferente, elaborador, mas, volta e meia introduz, especialmente nas Geórgicas, elementos de proteção sobrenatural na vida humana. Veja-se, por exemplo, o canto III, em que parece nítida a mão de uma divina Providência na direção do mundo. Particularmente nas ações de César, é notadamente observável a ingerência divina, o que nos leva a pensar de que, aos poucos, Virgílio vai se afastando da noção (epicurista) de que os problemas da humanidade sejam entregues tão completamente ao acaso. Durante a elaboração de Eneida essa pluralidade de idéias foi dando espaço para uma conclusão una: a de que havia no comando do Universo uma Providência divina a comandar as ações humanas. Na Eneida que chega a público, o poeta diz os Fados eram os responsáveis por tudo: destruição de Tróia, difíceis condições dos navegantes troianos, após fugirem da cidade incendiada e saírem em busca de outros ares e pelo que ocorre depois, aí incluindo Dido e Turno. Exemplo: "E impelidos dos Fados, muitos anos I Havia que andavam rodeando / Por todo o vasto mar (...)" (En, I, 49). A apaixonada Dido se lamentará: “(...) mas ele austero / A prantos não se move, nem algumas / Razões escuta: os fados lho proíbem, / E um deus Ihe obstrui os plácidos o uvidos" (En, IV, v. 660-1). E o narrador dá conta do sofrimento relacionado ao destino: "As lágrimas debalde deslizam. / Dos fados aterrada então a morte / Invoca a infeliz Dido (...)"(En, IV, 675-7). Mas, não só aos Fados encontramos na Eneida. Na tradução de Barreto Feio, que ora utilizamos, a palavra fado, assim mesmo, registrado em letras minúsculas, expressa a noção de destino ou sorte. Enéias dirá: "Ai! Me ficou para trás a cara esposa; / Se roubada me foi de triste fado, / Ou se caminho errou, ou se cansada / Se assentou, m'era incerto (...)" (En, II, 1115-7). 0 narrador dirá à rainha de Cartago: "Dido infeliz! Agora é que tu sentes / O rigor do triste fado! (...)" (En, IV, 896-7). E Apolo disfarçado falará a Ascânio: "Todas as guerras que hão de vir por fado / Serão devidamente apaziguadas" (En, IX, 940-1). Heleno diz a Enéias: "(Que assim o rei dos numes os destinos / Sorteia e dos mortais troca as fortunas: / M udar é da Natura lei constante.)" (En, III, 579-81). Até Juno se curva aos Fados, ansiando que esses apóiem sua decisão de impor a Cartago a condi ção de cidade mais importante, embora assuma o fato de ter ouvido de que outro povo deteria o privilégio de ter sua cidade como espécie de Capital do M undo: "Que fosse essa a metrópole do mundo, / Se os Fados consentissem, logo a deusa / Pretendera, e nutria essa esperança" (En, I, 26) e "(...) assim no fatal fuso as parcas / 0 fio dos sucessos envolveram" (En, I, 33-4) e mais adiante se perguntará: "(...) Desistirei vencida / Da começada empresa? Nem da Itália / Poderei afastar o rei dos Teucros? / Certo os Fados m'o vedam! (....)" (En, l, 58-61). Além dos Fados, Virgílio menciona o grande poder dos altos deuses, no destino humano pelo que se expressa, dentre outros trechos, na fala da sombra de Creusa ao consolar o desesperado consorte que perdera a esposa, a qual, sabemos, encontrava-se com Cibele: "(...) 0 que acontece / Não é sem permissão dos altos deuses. / D'aqui levar Creúsa não te é dado: / Do Olimpo o sumo rei o não consente" (En, II, v. 1176-8).Em outros momentos da narrativa épica, Virgílio elevará Júpiter ao posto de senhor incontestável dos destinos. Essa hipótese parece se confirmar, de igual modo, no Livro I, com a fala de llioneu, um dos companheiros de Enéias, mencionando a Dido sua condição pré-determinada, relacionada intrinsecamente ao deus: “Ó rainha, a quem deu o sumo Jove / Fundar nova cidade (...)" (En, I, 786-7). Em Eneida também é inserida a noção de que Júpiter - "O genitor de homens e de deuses" (En, l, 381) - é o onipotente e grande mandatário das causas humanas. Essa constatação chega ao leitor pelas palavras de alguns dos personagens. Por exemplo, Vênus: "Me prometeste que, volvendo os anos, / Da renovada geração de Teucro / Um dia surgiriam os Romanos / (...) / Como, ó padre, mudaste de conselho?" (En, I, 348-50, 353). 0 deus responde: "Não tenhas medo Citeréia: imotos / Os destinos dos teus se te conservam. / (...) / E deste meu propósito não mudo" (En, I, 383-4, 388). E passa a profetizar todo o futuro dos romanos. Diz que Juno protegerá com ele esse povo 
"Assim me aprouve. (...)"(En, I, v. 420). Mas, mesmo sendo Júpiter o grande autor do destino, enquanto ele planeja o futuro dos troianos, Juno e Vênus inserem novos rumos na trajetória de Enéias. 0 comando dos destinos, então, muda de mãos e passa para Juno e Vênus, as quais, alternadamente, planejam ações que interferem no destino de Enéias e os troianos. Juno procurava fazer o mal contra 0 povo que Vênus amava e protegia. As raízes para tanto ódio podiam ser encontradas na velha história do concurso de beleza do monte Ida. Todavia, em dado momento, ambas as deusas chegaram a se unir para, juntas, interferirem na história dos troianos, ao provocar a paixão da rainha de Cartago por Enéias ainda promoverem o casamento de ambos, o que Júpiter e/ ou os altos deuses, os Fados, ou quem quer que fosse, não haviam planejado nem autorizariam jamais. Da união dos ideais de ambas as deusas, portanto, é que surge o novo reino de Tróia, sintetizado pela cidade de Roma.

0 caráter é o destino?

Em suma, a piedade de Enéias - como força maior de seu caráter - o fará um ser totalmente submisso aos deuses - quase um títere, portanto. E a imagem não é excessiva, porque Enéias, embora queira dar a vida por sua cidade saqueada, é intimado a deixá-la às escondidas. Demonstrando carinho e atenção para com a esposa, a tem afastada de si. Quando encontra a mulher por quem se apaixona, não pode permanecer ao seu lado. Um deus Ihe surge em mensagem terrível e ele precisa abandonar a vida que começava a construir ao lado da amada. Ao final, sempre lembrado da missão de edificar um novo reino para seu filho continuar a estirpe dos romanos, é obrigado a lutar com Turno, para se casar com uma jovem completamente estranha, que não demonstra afeição ou manifesta qualquer laivo de simpatia por ele ou por sua causa. No entanto, embora haja a noção da ingerência dos deuses nas ações de Enéias, Virgílio não o deixa isento de responsabilidade na condução de seus atos ou culpa pelos mesmos. Enéias é forçado a agir. Concluindo a questão, a idéia da Providência divina a dirigir as ações humanas, em Eneida, não se encaixa na concepção de Fatum que Epicuro defendia (Conferir em (GRIM AL, 1992, p. 194). Virgílio inseriu em seu poema a noção de que, embora houvesse a inalterabilidade e rigidez do Fatum, Enéias precisava lutar para cumprir o mandato do Destino - a fundação de Roma. E isso não implicaria numa atitude de lassidão ou inércia. Já nas Geórgicas (também citadas em 0 fiel e a pedra) Virgílio preconizara a necessidade do trabalho árduo para se obter bons resultados com a terra. De igual modo, o herói de Eneida precisava se enfrentar as vicissitudes para chegar ao fim de sua missão e teria que conviver com críticas e julgamentos negativos.

cxxi Aquiles aconselha ao rei Príamo: “(...) aflitos, ambos, / deixemos que agora serene a dor no coração, / pois do pranto glacial não deriva nenhum / proveito. (...)" (II, XXIV, v. 522-5) . 0 guerreiro sugere ao rei troiano que suporte pacientemente os revezes: “(...) Desde quando os Urânios te enviaram / malefícios, batal has e carnagens cercam-te / a urbe. Sofre-os, paciente, e deixa de lamúrias; / por teu filho agoniarte, não fará com que ele / ressuscite, mas outro mal pode advir-te, antes" (II, XXIV, v. 547-51).

cxxii Odisseu diz de si mesmo: "Sou tolerante de espírito; muito já tenho sofrido / no mar furioso e na guerra (...)" (Od, XVII, v. 284-5). Outras personagens de Odisséia testemunharão dessa faceta do caráter de Odisseu, como M enelau, ao receber a visita de Telêmaco, lembrando que o pai do jovem fora o mais empenhado e sofrido dos guerreiros aqueus na famosa guerra contra Tróia e Hermes, dirá a Calipso que Odisseu também muito sofrera por haver sido o guerreiro que mais se empenhara no trágico conflito. M enelau e Helena recebem a visita de Telêmaco, o filho de Odisseu, que a mandado de Atena, saíra em viagem a fim de obter informações acerca do pai. Menelau narra um pouco das façanhas de Odisseu, dizendo, entre outras coisas: “(...) Nenhum dos Aqueus sofreu tanto / como Odisseu suportou e sofreu; o futuro para ele / muitos trabalhos guardara (...)" (HOM ERO. Odisséia. Tradução de Carlos Alberto Nunes. 3. ed. São Paulo: M elhoramentos, 1960, canto IV, v. 106-8, p. 60). Hermes dirá a Calipso, na visita que faz à ninfa, com a intenção de pedir que ela deixasse Odisseu partir: “(...) o varão mais sofrido de quantos / outros heróis na cidade de Tróia indefesos lutaram / por anos nove, e no décimo, alfim, conseguiram derruí-la" (V, v. 105-7). Alguns exemplos comprobatórios de epítetos de Odisseu em HOMERO. Odisséia. Tradução de Carlos Alberto Nunes. 3. ed. São Paulo: Melhoramentos, 1960: M uito paciente: XVIII, 311. Paciente: III, 84; IV, 241, V, 171, 486; XVII, 292; XXII, 261, 291; XXIV, 347. Revestido de tal coração paciente: IV, 270. Sofredor de trabalhos: VIII, 199, 446; XIII, 250; XVI, 186, 225; XVII, 16, 280, 559; XVIII, 281; XIX, 1, 51, 102; XX, 1, 92. Sofrido: VI, 1; VII, 1, 133, 177, 230, 329; XIII, 353; XVI, 90 , 104, 258, 266; XVIII, 90; XIX, 70, 106; XXI, 414; XXII, 191; XXIV, 232, 504. Varão mais sofrido: V, 105. 
cxxiii Ao longo da epopéia, Odisseu se mostra, no geral, esperançoso e confiante no futuro. Embora o herói se mostre desanimado e choroso em alguns momentos, como por exemplo, na paradisíaca ilha de Calipso, percebemos que são as saudades que provocam sua dor, não o desespero. Mediante a maioria das tribulações, Odisseu não fica totalmente isento de temor, sendo-nos informado pelo narrador de seus pavores diante das terríveis tempestades que repentinamente acontecem em sua jornada, como no caso exemplar: "Eis nossas naus a correrem sem rumo, as velas os ventos furiosos as rasgam, / o que nos faz amainá-las, receosos de mores desditas" (Od, IX, 70-3). O medo volta com intensidade em outra circunstância, deveras preocupante: na a caverna soturna de Polifemo. 0 narrador dá conta de que ante a voz do ciclope, Odisseu e seus companheiros sentem medo: "partiu-se-nos o coração no imo peito"( Od, IX, 256). Todavia, é a maneira de Odisseu lidar com seus medos e também com as razões desses, que nos causa admiração. 0 herói enxerga nessas situações geradoras de pânico não somente a crise, mas as vê como desafios que demandam rápidas soluções. E é de certa forma leve, quase que de passagem, a maneira como o narrador insere os problemas, enfatizando o olhar mais sobre a administração desse problema e também o inusitado, a engenhosidade humana ante os perigos, enfim, eventos que provocariam surpresa e admiração diante da capacidade do homem de se safar das situações de risco. É como se o narrador estivesse contando uma história de suspense e dirigisse o olhar virtual de seu auditório para a ação do herói - enfim, não importando tanto os monstros que aparecerem no caminho, mas, efetivamente, a atuação do cavaleiro em combatê-los. Talvez seja essa a causa de uma condição que salta aos olhos na Odisséia: o medo de Odisseu nunca é paralisante, ao contrário, provoca-o à ação. E, concedamos um crédito à narrativa dos feitos do grego: 0 herói nos apaixona, pela imensa capacidade de se safar das mais incríveis situações - seja pela esperteza, seja pela quase ingenuidade e carisma. 0 lema de Odisseu poderia ser resumido em uma de suas frases ao narrar ao rei Alcínoo sobre o desespero dos companheiros ao saberem que passariam pelo Hades: [Lamentar não resolve problemas] " 0 coração se Ihes parte, querido, a essas minhas palavras; / no chão se assentavam gemendo e os cabelos da frente arrancando / "M as não lhes vinha nenhuma vantagem de tantos lamentos [grifo nosso]" (Od, X, 568).

cxxiv Enéias também se caracteriza pelo sofrimento, conforme o poeta diz: "M uito por mar e terra contrastado / Foi do poder dos numes, pelas iras / Esquecidas jamais da seva Juno" (En, I, v. 4-6). Mas, ao contrário de Odisseu, o herói virgiliano é tomado pelo medo e chega mesmo a se apresentar de forma depressiva e paralisante. Veja-se sua reação ante certos acontecimentos sobrenaturais, como por exemplo, durante a visita de Mercúrio, que desce dos céus com a intenção de fazer-lhe lembrar de sua missão: "A tal vista, emudece e pasma Enéias: / Os cabelos de horror se lhe arripiam, / e nas fauces a voz Ihe ficou presa. / Atônito co'o aviso e ordem dos deuses" (En, IV, v. 407-10). 0 terror, nesse caso, adviria em função do forte teor de reprimenda, já que Enéias se encontrava enamorado de Dido e totalmente esquecido da incumbência de Ihe deram os deuses: fundar uma outra Tróia em um lugar distante dali. Ele sabia que estava agindo contra a vontade de Júpiter e outras divindades enquanto permanecesse em Cartago, vivendo as delícias do casamento com a rainha e auxiliando-a a construir sua cidade. 0 temor em vista de Mercúrio, portanto, e acrescido do sentimento de culpa pelo dever não cumprido. Em outra feita, ao ver os navios incendiados pelas mul heres desesperadas, que pensavam que nunca mais sairiam do local, Enéias tem uma reação bastante emotiva: "Rasga Enéias dos ombros o vestido, / Ergue as mãos e em socorro os deuses chama" (En,V, 984-5). Diferentemente do tão controlado e paciente Odisseu, Enéias entra em pânico diante das vicissitudes pelas quais passa e prostra-se horrorizado ante os deuses, aguardando uma solução para suas provas.

cxxv Premonições, presságios estão inter-relacionadas ao futuro dos heróis. Pouco vimos desses elementos em llíada. Aquiles mesmo diz que não é dado a augúrios: "Não me atenho a presságios" (II, $X V I, v .50)$. A Odisséia, todavia, é repleta de episódios em que esses elementos se tornam preponderantes para a seqüência da jornada do herói. Um deles é quando aporta no país dos ciclopes e Odisseu cuidado samente se prepara para ir à terra em razão do pressentimento que o assoma: "pois me dizia uma voz no imo peito valente que iria / ver-me defronte de um homem dotado de força excessiva, I bronco selvagem, ingaro das leis e do senso do justo" (Od, IX, 213-5). Outro exemplo de pressentimento - o qual funciona como elemento antecipatório - ocorre no passo em que M enelau, falando dos pretendentes, diz a Telêmaco: “(...) Odisseu a eles todos dará morte horrível" (Od, IV, 340). De modo semelhante funcionam os presságios. Um deles acontece na visita de Telêmaco a M enelau: uma águia sobrevoa a todos, tendo no bico um ganso doméstico. 0 filho de Nestor, Pisístrato, que 
acompanhava Telêmaco desde a casa do pai, pergunta ao anfitrião se aquilo poderia ser um sinal divino. Enquanto o marido pensa no assunto, Helena se adianta e informa a Telêmaco: "Ora me ouvi, que eu, também, predizer-vos desejo, tal como / na alma os eternos mo dizem e como, estou certa, há de darse" (Od, XV, 172-3). E continua: "Do mesmo modo que esta águia, dos montes descida, onde, certo, / filhos e ninhos deixou, veio o ganso pilhar-nos em casa: / dessa maneira Odisseu, pós trabalhos e viagens sem conta, / há de voltar para casa e vingar-se (...)" (Od, XV, 174-7). E acrescenta um dado relevante: “(...) Talvez já se encontre / lá, de retorno, a pensar no castigo que vai dar a todos" (Od, XV, 177-8). Outro presságio recebe Penélope. Ao dizer que se fosse possível ao esposo retornar à pátria, ele e o filho poderiam se vingar dos pretendentes, Penélope ouve Telêmaco espirrar e, sorrindo, diz a Eumeu, o porqueiro: "Não escutaste meu filho espirrar, quando há pouco eu falava? / Isso é sinal que da M orte nenhum, sim, nenhum pretendente / há de fugir, atingindo a eles todos o negro Destino" (Od, XVII, 545-7). M enção de presságio também ocorre após Odisseu retornar a casa. Ao encontrar a deprimente situação de arrogância exploração, por parte dos pretendentes, roga um sinal a Zeus ante sua decisão de intervir no caso: "dá que aqui dentro de casa alguém diga, acordado, palavras / de fausto agouro, e que fora me venha um sinal de tua parte" (Od, XX, 100-1). Zeus atende o pedido de Odisseu: "Isso disse ele, implorando; Zeus sábio acatou-Ihe o pedido. / Fez trovejar na mesma hora do Olimpo escampado e brilhante," U ma serva, cuja exigência de trabalho em razão das inúmeras festas é mais do que pode suportar, é o canal para a expressão verbal do presságio: "Uma das servas que perto moíam, Ihe disse o presságio" (Od, XX, 102-3). A mocinha vira o trovão sem nuvens ou chuva e dissera a Zeus: “( ...) parece um sinal de tua parte" (Od, XX, 114) e acrescentou: "Cumpre o pedido, também, que te faz uma escrava sem sorte: / Que os pretendentes soberbos pela última vez, neste dia, / gozem na casa do herói Odisseu do mui grato banquete." (Od, XX, 115-7)

Em Eneida, os Fados, como destino, estão correlacionados a profecias. Dentre os tantos exemplos, citaremos alguns: 0 episódio do cavalo de Tróia, em que Cassandra, a profetisa, tenta advertir (sem sucesso) aos concidadãos acerca do perigo iminente ao receber o estranho presente dentro da cidade; depois da tomada de Tróia, o sonho de Enéias com Heitor, aconselhando o guerreiro a deixar a cidadela e carregar os penates como companheiros de seu fado; a predição das Hárpias de que os troianos iriam roer as próprias mesas; 0 augúrio de Heleno, o grande profeta que encaminha Enéias à sibila de Cumas. "(...) Cassandra os fados / Inda anunciou futuros, dos Troianos, / Por preceito de Febo, jamais crida" (En, II, v. 378). Também nos lembramos de que Heitor em sonhos dirá a Enéias: "Os sagrados objetos de seu culto / Tróia te recomenda, e os seus penates, / Toma-os por companheiros de teus fados" (En, II, v. 450-2). E nos recordamos da predição feita pelas Hárpias, de que os troianos iriam "roer as próprias mesas" (En, III, v. 406), augúrio que muito preocupará Enéias e seus companheiros e que Heleno aplacará, dizendo: “Os fados acharão saída (...)”(En, III, v. 608). Heleno é um vate que também profetiza o futuro dos enéadas, embora parcialmente. Heleno diz a Enéias que as Parcas não permitem que ele saiba o futuro: "Das muitas palavras que saber quiseras, / Te direi poucas (...) / (...) / Qu'as demais ou as Parcas não consentem / A Heleno qu'as saiba, ou Ihe proíbe / A filha de Saturno que tas diga" (En, III, 582-3, 586-8). Todavia, ele orientará Enéias a procurar a Sibila, de Cumas: "Profetisa verás que os fados canta" (En, III, v. 678). E não só a profecias se relacionam os fados, mas também a sinais, augúrios. 0 lume (En, II, v. 1036-60) da cabeça de Ascânio, bem como a estrela cadente, ambos sinalizando a Anquises que ele deveria acompanhar o filho na retirada de Tróia. Os cisnes (En, I, v. 580-600) que indicam a Enéias que seus companheiros estão sãos e salvos. As pombas (En, VI, 279-310) que indicam a Enéias a árvore do ramo de ouro.

cxxvi Dodds diz: "Na verdade, é assim que devemos esperar que falem as pessoas que acreditam (ou cujos ancestrais acreditavam) em constantes avisos do além. 0 reconhecimento, a intuição, a memória, a idéia perversa ou brilhante, possuem isso em comum; eles chegam repentinamente 'à cabeça de um homem'. Freqüentemente ele não tem consciência de nenhuma observação ou raciocínio que o tenha levado a tais conclusões. Mas se é esse o caso, como ele pôde designá-las como 'suas'? Há um instante atrás elas não estavam na sua mente e agora estão. Alguma coisa as colocou ali. E este algo é diferente de si próprio. Ele nada sabe disso, e portanto, fala do que ocorre de maneira reservada, como da ação de 'deuses' ou da ação de 'al gum deus', ou ainda, mais freqüentemente, (sobretudo quando acontece de seu ef eito ser ruim) como da ação de um daemon" (Dodds, p. 20). Um exemplo dessa condição ocorre em: "Como voltaste, Odisseu? Qual anverso demônio te trouxe?" (Od, X, 64). 
cxxvii Os pressentimentos - ou seja, pensamentos mais fortes sobre algo que poderia acontecer brevemente - advêm a Bernardo, Teresa e Ascânio. Outros personagens, como Nestor, Suzana, Miguel, não são encampados por esse viés profético e os do terceiro time, como Xenofonte, Maria Genuína, Cizilião e outros, também não percebem o futuro da maneira como as personagens principais o fazem. Aliás, deles não conhecemos os pensamentos, as intenções, pois o narrador se concentra no trio referido.

cxxviii A imagem da porta é figura bíblica recorrente, sendo a mais famosa no mundo cristão, a de Cristo batendo numa porta, insistindo em participar da comunhão dentro do lar, o que remete ao conhecido trecho de Apocalipse: "Eis que estou à porta, e bato. Se alguém ouvir a minha voz, e abrir a porta, entrarei em sua casa, e com ele cearei, e ele comigo" (Apocalipse 3:20). A balança é metáfora que aparecem em muitos livros da Bíblia, representando honestidade, comércio reto e o julgamento divino (A imagem da balança aparece em muitas passagens bíblicas. Citaremos algumas a título de exemplo: Provérbios 11:1 diz : "O peso e a balança justas são do Senhor". Daniel 5:27 diz que o rei fora pesado na balança e achado em falta; Apocalipse 6:5 dirá: 0 seu cavaleiro [Jesus] tinha uma balança na mão"). A foice é outra intensa metáfora que se relaciona ao jul gamento divino (A imagem da foice representa 0 julgamento divino. Joel 3:13 “Lançai a foice, pois já está madura a seara. Vinde, descei, porque o lagar está cheio, os vasos e os lagares transbordam; porque a sua malícia é grande" ; Apocalipse 14:15:

"Lança a tua foice e ceifa, porque é chegada a hora de ceifar e a seara da terra já está madura"; 14:18: "Lança a tua foice afiada, e vindima os cachos das vinhas da terra, porque as suas uvas já estão maduras"; 14:9: "E 0 anjo meteu a sua foice à terra e colheu as uvas da vinha da terra, e lançou-as no grande lagar da ira de Deus"). A segunda, a imagem da foice está sempre empregada na colheita que também é usada de forma metafórica, sugerindo o fim.

cxxix Transcrevemos o texto à maneira exata em que se encontra no romance: " - 'E ouviu-se um estrépito e clamor imenso.' (HOM ERO, Ilíada, rapsódia XLI.)" [OFP, 283]; mas, consideramos ter havido um equívoco na numeração da rapsódia, pois a llíada é dividida em 24 cantos (em algumas versões, "livros" ou "rapsódias").

cxxx "Quase Néstor, então lhe diz Ôneiros, divo / Filho de Atreu (...) dormes / o bom sono? E o povo? (...) (IIíada II, 23)"; "Dormes Aquiles, e te esqueces de mim" (II, XXIII, 69:); e o sonho com Iftíma, a irmã de Penélope, na versão em que nos debruçamos assim se mostra: "Dormes, Penélope, com o coração de tal modo angustiado? / Não te consentem os deuses, que vivem em feliz existência, / tanto chorar e afligirte (...)" (Odisséia IV, 804).

cxxi (DODDS: 2002, p. 122, citando frag. 89D e outros). 0 autor de Os gregos e 0 irracional, ao dedicar um capítulo à atitude dos gregos quanto aos sonhos, escolheu uma abordagem cujo norte é o olhar dos antepassados, evitando analisar a questão sob uma perspectiva moderna. Essa opção se deu em face da constatação de que o sonho tem a ver com o tipo de crença acalentada: "Não é apenas a escolha deste ou daquele símbolo, mas a própria natureza do sonho que parece conformar-se com um padrão rígido imposto pela tradição. É evidente que tais sonhos estão intimamente relacionados ao mito (...)." (DODDS: 2002, p. 109). Além de mencionar Heráclito como o primeiro a discorrer mais acuradamente sobre sonhos, o estudioso também cita Aristóteles, o qual, nos ensaios Sobre os sonhos e Sobre a adivinhação nos sonhos, expressa descrença acerca da provável origem divina dos estados oníricos. Apesar de tudo, o sábio classifica alguns tipos de sonhos como daemonicos, porque, segundo ele, a natureza é daemonica. Aristóteles define dois tipos de sonhos: "sonhos conduzindo a um conhecimento prévio de saúde do sonhador, razoavelmente explicados pela penetração na consciência de sintomas ignorados durante as horas de vigília; e aqueles que se realizam pela sugestão da trajetória de ação para o sonhador". (DODDS: 2002, p. 124). Ao final, Dodds considera que a humanidade não conseguiu apreender muito mais do que isso acerca dos sonhos e relembra que muitos latinos importantes, como Marco Aurélio, Plutarco, Dio Cassio e Galeno deixaram-se influenciar pelos sonhos e suas possíveis interpretações so brenaturais.

cxxxii Em nota de fim de texto, Dodds cita o sonho de Agamenon, com um Ôneiros, citado acima (llíada II, 23). 
cxxiii “Era no tempo em que o primeiro sono / Aos cansados viventes principia / E em que este dom benéfico dos deuses / Pelos membros gratíssimo serpeia. / E eis que em sonhos Heitor se me afigura / (...) / (...) Ah foge, e destas chamas / Te salvas / (...) / Os sagrados objetos de seu culto / Tróia te recomenda, e os seus penates. / Toma-os por companheiro de teus fados, / Uma nova cidade Ihes procura" (En, II, 410-4, 443-5,450-3). Depois que rompe com Dido: "Para a viagem e certo da partida, / Sobre a alta popa ao sono se entregara: / Quando a figura em sonhos Ihe aparece / Do mesmo deus que admoestá-lo torna / (...) Filho da deusa, / Dormes n'uma tal crise? Não vês (louco!) / Que iminentes perigos te rodeiam?" (En, IV, 840-9). Enéias conta a Dido que o pai, Anquises, Ihe aparece em sonhos e o recrimina pela demora em continuar jornada para fundar a cidade de Roma: "Em sonhos m'admoesta e repreende / A torva imagem de meu pai Anquises" ((En, IV, 518-9).

${ }^{c x x x i v}$ A llíada descreve um Enéias "ávido de guerra" (II, XIII, 469-70). Juntamente com Heitor, é considerado dos "troianos mais fortes" (II, XVII, v. 515-6). 0 grego Idomeneu, ao ser acuado por Enéias, conclama os companheiros para ao salvarem, dizendo ser o troiano, há tradução de Campos, um "pésrápidos" "um matador de gente, terrível", "na flor da idade, quando a força avulta" (II, XIII, v. 481-7). Homero diz que tanto Idomeneu quanto Enéias são "pares do deus da guerra" (II, XIII, v. 501). 0 narrador irá chamá-lo de "encarniçado matador", ao saltar sobre um guerreiro grego, Afareu Caletório, descrevendo a forma sanguinária com que 0 atinge: "espeta-o na laringe com a lança aguda" (II, XIII, v. 540-2). 0 guerreiro grego, M eríone, ao enfrentar Enéias, Ihe diz que, embora tenha "coração valente" (II, XVI, v.s 619-26), ainda é um mortal e poderá ser ferido na guerra. Em dado momento da guerra, Enéias faz parte dos guerreiros de Heitor, ao se lançarem todos, após a grande inundação perpetrada pelos deuses, contra as muralhas dos gregos. Na tradução de Campos, o herói é descrito como estando entre "os mais bravos, os mais numerosos, sequiosos de, rompidas as muralhas, dar combate aos Aqueus junto às naves bicôncavas." (II, XII, v. 89-91). No famoso duelo com Aquiles, um Enéias impaciente, repleto de ímpeto bélico, ávido de enfretamento, diz a Aquiles que não adianta o discurso de persuasão, eles devem mesmo lutar: "Não me farás, porém, recuar, com palavreado, / do ímpeto que me anima de enfrentar-te a bronze. / Antes, tercemos lanças brônzeas, e depressa." (II, XX, 256). Um Enéias arrojado não se deixa intimidar pela força e instinto matador do sanguinário Aquiles e é o primeiro a avançar "meneando 0 elmo sólido, ameaçador; diante do peito soergue o escudo resistente,e brande a lança brônzea" (II, XX, 159-63) e dá início ao duelo mortal. A luta é descrita de forma grandiloqüente, como em todo o texto homérico, mas o narrador insere um detalhe curioso: Enéias, em dado momento, pega de uma grande pedra - "mó enorme, que dois homens, dos de hoje, não susteriam, e ele, só, erguia, fácil (...)"(II, XX, 286-89) e faz o mesmo que uma personagem de 0 fiel e a pedra, Maria Genuína, fará ao amásio, após ser agredida, mais uma vez, pelo mesmo. Enéias, além de, individualmente, mostrar-se como um guerreiro audaz e indômito, apresenta-se como um líder de grande influência entre os guerreiros troianos, sendo chamado de "soberano de homens" (II, V, 311) pelo narrador, ao concitar à luta e insuflar o ânimo. Pelo guerreiro tróico Licaone é chamado "consel heiro dos bronziarnesados Troianos" (II, V, 180).

No episódio da morte de Pátroclo, o amigo de Aquiles, por exemplo, Enéias se opõe à entrega do corpo do rapaz, conclamando à luta, instigando a hombridade dos conterrâneos, o que se apreende pela veemência de suas palavras: "(...) Héctor, e vós outros, chefes / dos Troianos e aliados - que vexame! acuados / por Aqueus, prediletos de Ares, regressar / para ĺlion, dominados por faltar-nos fibra. / (...) / Aos Dânaos, pois! Sem óbice, / não deixemos que às naus levem Pátroclo morto!" (II, XVII, 334-40). Um Enéias enraivecido se mostra ao leitor de llíada e essa raiva transparece nas palavras grandiloqüentes, no embate com M eríone: "O coração de Enéias enraivece. Ele fala, / então, para M eríone: 'Ainda que fosses hábil / dançarino, meu dardo, caso te ferisse, / haveria, para sempre, de paralisar-te.'" (II, XVI, 615-18)

cxxv Um aspecto marcante de Enéias iliádico é sua filiação divina. No duelo com Aquiles, ele lembra sua origem, insinuando a inferioridade divina da mãe do grego: "Conhecemos, nós dois, nossas estirpes; nós / dois conhecemos - bem a conhecemos - nossa / progênie, no epos dos heróis mortais cantada. / Em pessoa nunca vi teus pais, nem viste os meus. / De peleu e de Tétis, belas-tranças, filha- / -do-mar-salino - dizem- nasceste. Sou filho / de Anquises, animoso, e da deusa Afrodite." (II, XX, 203-9). (Interessante que nesse passo, Enéias diz a Aquiles que ambos já fazem parte da mitologia, com a frase: "nossa progênie, no epos dos heróis mortais cantada") . Afrodite, incansavelmente, protege o filho. Em dado momento da guerra, Enéias é ferido e a divina mãe se apresta em socorrê-lo: "E o soberano de homens 
teria sucumbido, / se não o percebesse Afrodite, olho agudo, / que de Anquises, pastor-de-bois, 0 concebera; / rodeou o filho amado com os braços brancos / e desdobrou-Ihe diante o peplo resplendente, / amparo contra os dardos dos Dânaos (...)" (II, V, 311-6). A imagem revestida de extrema doçura - a mãe amorosa descendo lépida do céu para cuidar do filho ferido e o proteger com seu manto maravilhoso - comoverá os corações de todos os tempos, particularmente os latinos, certamente contribuindo para a composição da lenda do herói troiano - lenda que alcançará o ápice na Eneida do sensível Virgílio. Homero já apontava em Enéias o fato de ser protegido, não só pela mãe, mas por outros deuses do Olimpo. Tal constatação aparece nas palavras do estarrecido Aquiles, após Enéias desaparecer maravilhosamente da guerra: "Sim, Enéias era caro aos deuses imortais, / e eu a crer que isso fosse uma fátua jactância!" (II, XX, 348-50).

cxxxi Grimal esclarece sobre o assunto: “Contrariamente à opinião generalizada, os epicuristas não eram ateus. Acreditavam na existência dos deuses, que levavam, nos intervalos entre os mundos, uma vida serena, exatamente a vida prometida pela do utrina. Sem poderem atuar sobre o mecanismo das coisas, que se desenrolava em virtude das leis da física, fora de qualquer intervenção, nem por isso deixavam de comunicar-se com os homens por meio de sonhos: seres materiais que eram, emitiam, como os obj etos e os seres de nosso mundo, 'simulacros' muito tênues, imagens à sua semelhança, que se insinuavam entre os olhos dos homens e atingiam seu espírito durante o sono. Para percebê-los, era preciso que o espírito estivesse em repouso total" (GRIM AL, Pierre. Virgílio ou o segundo nascimento de Roma. Tradução de Ivone Castilho Benedetti. São Paulo: Martins Fontes, 1992, p. 80).

cxxvii Transcrevemos o texto à maneira exata em que se encontra no romance. Na tradução de Carlos Alberto Nunes: "Pela corrente do oceano perpassam, as pedras de Leucas / e as claras portas do sol, assim como os domínios do sonho, / té que, afinal, alcançaram o prado coberto de asfódelos, / onde se achavam reunidas as almas dos mortos" cxxxvii . E na tradução de Odorico Mendes: "Vão-se ao fluido Oceano e à Pedra-Branca. / Do Sol às portas e ao dos Sonos povo. / Em prado verde, habitação dos manes" cxxvvii . No rodapé dessa tradução, os editores informam que Pedra-Branca era um "rochedo com escarpas no mar Jônio, onde os condenados à morte eram precipitados no abismo". Manes seriam as almas, fantasmas dos mortos. Também trazemos a forma em que o texto se encontra na tradução em prosa de Antonio Pinto de Carvalho: "Passaram além da corrente do Oceano e da rocha Lêucade, ultrapassaram as portas de Hélio e o país dos Sonhos, e depressa alcançaram o prado de Asfódelo, onde habitam as almas, fantasmas dos defuntos" (HOMERO. Odisséia. Tradução de Antonio Pinto de Carvalho. São Paulo: Nova Cultural, 2002, Rapsódia XXIV, p. 304).

cxxxvii 0 autor insere as referências: CAM ÕES, Lusíadas, Canto Sexto e HOM ERO, Ilíada, rapsódia XLI (OFP, 283).

cxxxix Camões poderia estar retomando, de forma indireta, alguns filósofos do passado grego, como Platão, que menosprezava os poetas por sua extrema sensibilidade e Epicuro, que defendia 0 afastamento das Musas.

cxl O autor escreve: CAM ÕES, Lusíadas, Canto Sexto (OFP, 283).

cxli Estamos nos referindo às citações anteriores: " 'Agora conto a história / de um macho de coragem, / valente sem pabulagem / e natural da Vitória'. (Do cancioneiro popular) e "Impôs a Natureza a lugares certos estas leis e estas imutáveis condições, imediatamente depois que Deucalião, pelo orbe vazio, esparziu pedras, donde nasceram os homens de raça dura'. (Virgílio, Geórgicas, Ivr. I.). Citações em epígrafes antes do capítulo I.

cxlii Grimal aborda a cosmogonia em Virgílio "Convém, pois, acreditar que a Eneida tenha sido a finalização, entre outras razões e sentimentos que levaram Virgílio a escrever, de uma longa ambiç̧ão obstinadamente afirmada: aquele homem modesto, tímido, inimigo da multidão e do fausto, íntimo dos maiorais, de Otávio triunfante e de Mecenas, que, se quisesse, poderia ter compartilhado com os vencedores os despojos dos vencidos - receber, por exemplo, como Horácio, uma villa cujo produto teria assegurado seu bem-estar - aquele homem carregava em si um único desejo: penetrar, apenas 
com a força de seu espírito, os segredos mais ocultos do Universo e fazer sua revelação sob a forma de poema épico, onde estariam contidas, ao mesmo tempo, uma filosofia do mundo (será a revelação de Anquises, no livro VI) e uma filosofia da História, na medida em que esta estava por inteiro contida no Destino de Roma. Esse poema seria dominado pela emergência de certo modelo humano, encarnado na pessoa do Fundador, Enéias, e que depois repercutira de geração em geração até 0 'jovem herói' que seria percebido, ao longe, na floresta dos símbolos e dos mitos" (GRIMAL: 1992, p. 192). Camões entrega-nos uma bela imagem que se relaciona ao Universo: a do primeiro móbile: "Enfim, que o sumo Deus, que por segundas / Causas obra no mundo, tudo manda. / (...) / Debaixo deste círculo, onde as mudas / Almas divinas gozam, que não anda, / Outro corre tão leve e tão ligeiro, / Que não se enxerga: é o Móbile primeiro / Com este rapto e grande movimento / Vão todos os que dentro tem no seio; / Por obra deste, o Sol, andando a tento, / 0 dia e noite faz, com curso al heio. / Debaixo deste leve anda outro lento" (CAM ÕES. Os lusíadas. São Paulo: Jackson, 1956, v. VII, canto X, estrofe 85-6, p. 355).

cxliii "Bernardo estava há mais de um mês no Engenho, quando foi apresentado a Nestor no armazém. Numerosas vezes encontrara- 0 , mas nunca Ihe falara, jamais o observara de perto e a impressão que teve foi das mais intensas. Como justificar a certeza de que aquele homem, mais do que Miguel, estava ligado à sua vida e de maneira funesta?" (OFP, 56-7).

cxliv “(...). Um carneiro balia. Ele olhou em redor. 0 sol ardia no céu (...). Aquela beleza, aquela ensolarada amplidão, doíam e atraíam ao mesmo tempo. A morte era triste, era duro morrer antes do fim, com o sangue a pulsar em toda a sua força, lavando veias novas, e a vida pela frente, cheia de acontecimentos e de estradas não vistas e também de caminhos percorridos aos quais sonhava tornar (...). Talvez morresse naquela tarde, quem sabe o que poderia acontecer? Morrer. A carne fria, os olhos murchos, o sangue derramado, as veias ocas. Talvez fosse morto - e quem, além de Teresa, haveria de chorá-lo? Estúpida morte, morte de um animal. Triste vida. E nem ao menos haveria uma testemunha fiel, para ver a sua morte e dizer se ele morrera como um homem" (OFP, 272).

cxlv “Único a pressentir a verdade, que adivinhara desde o dia em que vira Nestor ante o irmão e à qual todos pareciam cegos. Pressentia a verdade e ninguém, senão ele, podia proclamá-la" (OFP, 95).

cxlvi Não somente nesse caso, da morte de Miguel, persistirá a incógnita. Também na traição de Creusa acontecerá o mesmo. Como uma Capitu nordestina, obteremos da esposa de M iguel testemunhos de outrem, predominando a voz do marido ciumento.

cxlvii "Contemplou novamente a mulher. Que lembravam aqueles pés cruzados, que impressão dolorosa acordavam, tão quietos e humildes? (...) Aqueles pés... 0 sangue e o calor como que fugiram do peito, deixaram-no álgido e vazio, uma esponja seca: a mulher a quem sangraram o marido em Glória do Goitá fora encontrada assim, estripada, as mãos e os pés juntos, atados numa embira" (OFP, 214).

cxlviii "Se eu não voltar... Um Padre-Nosso... E muito obrigado, Bernardinho, você é sempre o mesmo. Só um Padre-Nosso" (OFP, 223). "Padre-Nosso, tumor. Talvez fosse mentira, um embuste a mais. E aquele gesto, aquele beijo? Seria mentira, o beijo no ombro? Sensação aborrecida, era como ser marcado, assinalado pelo que ia morrer" (OFP, 223).

cxlix “(...) os que eram mortos no campo iam assim. Estranhos levavam-nos, passo firme, os punhos da rede amarrados num caibro, o caibro nos seus ombros: entravam na cidade, arriavam a carga no cimento escuro da cadeia, diziam frases brutais sobre o peso do morto, voltavam, esqueciam. As moscas farejavam o sangue, voavam em enxames grossos sobre a rede" (OFP, 251).

cl "Grandes nuvens estáticas, até então invisíveis, revelavam-se agora, pardacentas, à luz do amanhecer: e aquelas mais densas, agrupadas na barra do nascente, pulsaram, banhou-as um rubor (...).

(...) Bernardo segurava as rédeas sem falar, parecia alheio ao despontar do sol. Teresa contemplou as duas massas de nuvens que pairavam como asas sobrenaturais à esquerda eà direita dos seus ombros, uma lembrando as crinas prateadas de um cavalo, a outra semelhante a uma trombeta, ou à pá recurva de um moinho, absurda escadaria de cirros, com suas lajes imensas, unidas no espaço eterno. (...). Tudo 
falava uma linguagem cujo sentido ela não podia alcançar - e isto a fazia tremer, pois aqueles sinais eram terríveis em sua grandeza. Como suportar, como entender?" (OFP, 260)

cli Transcrevemos o texto à maneira exata em que se encontra no romance e observamos que esse salmo, na tradução de João Ferreira de Almeida para a Bíblia, terá o número 22 e o versículo correspondente será de mesmo número. A BÍBLIA DE JERUSALÉM (conferir bibliografia) traz o número 22 mantendo entre parêntese 021 , para que os leitores não se percam em dúvidas. 0 salmo bíblico de onde Osman Lins extraiu o fragmento citado foi composto por Davi, o jovem pastor que se entretinha nos campos a cuidar dos rebanhos e que, nas muitas horas solitárias compunha e cantava ao som de sua harpa. Davi também detinha o dom de profecia e nesse salmo descreve o futuro sofrimento do M essias na cruz, cerca de mil anos antes de Jesus nascer. Estudos arqueológicos testemunham dos lugares (as cidades e acidentes geográficos, os costumes) e povos (por exemplo, filisteus, os inimigos da época) e batal has ou edificações (há documentos com narrativas de outros povos, sobre os feitos dos reis de Israel) mencionados na Bíblia no período em que Davi viveu e reinou (conferir em KELLER: 1984, p. 198205, 418-21; ALEXANDER: 1987, p. 21-3, 33, 44, 67-75, 103-4, 250-2, 266-7). No sentido do dialogismo, a própria epígrafe possui essa condição. A imagem do Messias crucificado foi um tipo de um antítipo: 0 cordeiro que os judeus sacrificavam em seus rituais religiosos, bem como 0 ato do patriarca Abraão doar seu único filho como prova de fé. Assim sendo, na imagem do salmo que é base para o capítulo de 0 fiel e a pedra, percebemos outras imagens aglutinadas. Essa concepção nos remete a André Jolles, em suas considerações sobre a legenda. Abordando o efeito de imitação provocado pelos santos, e chegando ao Ser mais santo dentre todos, o estudioso afirma: “(...) os acontecimentos da vida do Cristo podem ser concebidos sob o ângulo da imitação; é possível ver neles, como no Evangelho Segundo São Mateus, a realização de um discurso anterior: 'cumprindo assim o anúncio feito pelo profeta Jeremias, que disse...' Ou considerar ainda os acontecimentos do Novo Testamento a repetição de um evento do Antigo Testamento,sendo o sacrifício da cruz, por exemplo, prefigurado pelo sacrifício de Abraão." (JOLLES: 1976, p. 41). O M essias do salmo, cujos versos constam no romance osmaniano, fora representado antes pelo cordeiro que os judeus sacrificavam em seus rituais religiosos, bem como pelo famoso episódio do patriarca Abraão quase fazendo o mesmo com seu filho Isaque. Então, poderíamos dizer que o Filho de Deus pregado na cruz trazia em Si todos os cordeiros sacrificados antes ou os filhos dedicados aos céus. Seu corpo pendente era uma oferta múltipla dos milhares de sacrifícios que existiram antes dEle e que existiriam depois - de formatos diversos, por exemplo, como os corações contritos e sofredores. Quando a bondade e a fé se sentem acuadas perante o Mal, ocorre um sacrifício do próprio eu - o Bem.

clii Buscamos o salmo em sua totalidade para descobrir elementos análogos ou díspares (como o fazemos com todas as citações) e encontramos em muitos versículos do poema diversos graus de afinidade com a idéia do capítulo de 0 fiel e a pedra, em que se encontra a epígrafe bíblica: "Deus meu, Deus meu, por que me desamparaste? (...) Todos os que me vêem zombam de mim, estendem os lábios e meneiam a cabeça, dizendo: Confiou no Senhor! livre-o ele, livre-o, pois nele tem prazer". (...). "Muitos touros me cercaram, fortes touros de Basã me rodearam. Abrem suas bocas, como um leão que despedaça e que ruge. (...) Pois me rodearam cães; 0 ajuntamento de malfeitores me cercou, traspassaram-me as mãos e os pés (...) . Livra a minha alma da espada e (...) da força do cão"

cliii Os cães eram odiados por viverem em bandos sorrateiros e se atirarem a qualquer ser morto ou semimorto, devorando carne e ossos em instantes. Assim sendo, a comparação entre homem e cão remetia a qualidades não muito apreciadas socialmente, como a avidez, a violência, pois os cães atacam em bandos, o espírito belicoso, a deslealdade, dentre outros aspectos repudiados. 0 narrador, em dado momento, assimilará os capangas de Nestor Benício a cães, ao dizer que um dos deles rosnara (OFP, 111). E a metáfora é comentada por Biedermann: "Enquanto por um lado se impõem a força de sua natureza selvagem, a obtusa brutalidade de seus ataques, do modo como é vivenciada pelo homem, incute medo" (BIEDERM ANN: 1993, p. 365). Biedermann diz: "Na área cultural islâmica, o cão é considerado impuro (...)" (idem, ibidem, p. 69).

cliv Esse fator premonitório será um dos grandes alicerces na construção de 0 fiel e a pedra, o que Regina Igel já observara em seu livro Osman Lins - uma biografia literária, função que a estudiosa denomina modelo arquetípico de predeterminação: “(...) a leitura do futuro foi adaptada por Lins, que a reteve nas 
páginas do romance através de previsões intuitivas de Bernardo. A esta personagem coube o papel de antecipador de ações (...)" (IGEL: 1988, p. 53).

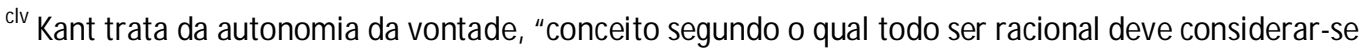
legislador universal por todas as máximas da sua vontade para, deste ponto de vista, se julgar a si mesmo e às suas ações (...)" (KANT: 2007, p. 75).

clvi Kant prega: "Age como se fosses ao mesmo tempo legislador e súdito na república das vontades" (HUISM AN, VERGEZ: 1982, p. 262, ver também KANT: 2007, p. 76-9). Segundo informam Durozoi e Roussell: "O esquema intelectualista decompõe 0 ato voluntário em quatro fases: a concepção do projeto a ser realizado, a deliberação durante a qual são apreciados os motivos e os móveis, a decisão que conclui a deliberação por uma escolha e a execução que é a passagem do ato." (DUROZOI,ROUSSEL: 1993, p. 488).

clvii O livre-arbítrio remete à liberdade, definida pelos especialistas citados e apoiados na longa história do pensar humano, das considerações de Aristóteles a Sartre, como o estado do ser "que só obedece à sua vontade, independentemente de qualquer coerção externa (o homem livre é o contrário de um escravo)" (DUROZOI, ROUSSEL: 1993, p. 288). A liberdade, portanto, é um atributo do ser livre, em oposição ao ser escravo - e nesse caso, estamos laborando na conceituação de escravo em relação à sua própria vontade, não na conotação histórica da palavra. Segundo Aristóteles, explicitado por Chaú, é livre a pessoa que traz em si o princípio de agir ou não agir, isto é "aquele que é causa interna de sua ação ou decisão de não agir. A liberdade é concebida como o poder pleno e incondicional da vontade para determinar a si mesma ou para ser autodeterminada" (CHAUÍ: 1995, p. 360).

clviii O autor informa a fonte: VIRGíLIO, Geórgicas, livro I (OFP, 60).

clix (...) a vontade outra coisa não é senão a razão prática" (KANT: 2007, p. 47).

clx Grimal comenta o fato: "Diante dessa visão, Enéias lamenta nunca poder conversar com a mãe, segurar sua mão; mas a deusa desaparece de sua frente - e será sempre assim, em todo o resto do poema: as divindades aparecem a Enéias, mas sempre em sonho, ou sob algum disfarce, o que confere certa incerteza à sua presença. Virgílio estaria lembrando a teologia epicurista, mesmo quando recorria, como o gênero épico, à 'teologia dos poetas'? As epifanias, as aparições dos deuses aos mortais são, para ele, coisas do espírito, mais que dos sentidos e da realidade carnal" (GRIM AL: 1992, p. 216). Mais adiante, o estudioso concluirá: "E esse é o problema de Enéias: como discernir o que vem dos deuses do que não passa de ilusão?" (GRIMAL: 1992, p. 229) - o mesmo problema de Bernardo.

clxi “Bem depressa alcançavam a corrente do Oceano e a Pedra Branca, enfiaram pelas portas de Hélios, ultrapassaram o País dos Sonhos, e ei-los enfim no Prado dos Asfódelos, onde habitam as Almas, imagens dos Mortos." (Od, rapsódia XXIV) [OFP, 254].

clxii HOMERO. Odisséia. Tradução de Antonio Pinto de Carvalho. São Paulo: Nova Cultural, 2002, Nota 1, de rodapé, da Rapsódia XXIV, p. 303.

clxiii “No momento em que estendeu a mão para o chapéu, foi assaltado por uma espécie de lembrança ou de pressentimento, a consciência de uma realidade malévola e obscura. Como quem busca ouvir, mal desperto, um grito de socorro só existente em sonho, voltou-se para fora (...) ele sabia que o chamado existia - real e enérgico - embora tão fugitivo, que fora impossível apreender a sua verdadeira significação. Entrevira uma verdade sem rosto. 0 mais inquietante era a convicção - que não Ihe vinha da mente, mas vibrava em cada músculo - de que a realidade lembrada ou pressentida não se referia a ninguém, a nenhum fato presente: aguardava-o além do lugar ou do minuto em que estava. Com 0 corpo inteiro ele recebia aquela realidade e era o mesmo que penetrar na escuridão.

(...) E Ihe veio a certeza de que era a Morte que ele pressentia. Era ela que se aproximava, que se anunciava, rondando-o como nos livros de gravuras" (OFP, 303). 
ckxiv “Não mais lutar, não mais viver. Por quem, por quê? Tinha um cadáver no corpo, um morto, um morto negro e sujo" (OFP, 307). E a voz que o chama antes dos tiros finais poderia ser desse morto: "De algum lugar - do campo, do passado - ou era o morto no corpo? - alguém chamava-o. Não era 0 seu nome, talvez nem fosse uma voz, mas ele sabia que o chamavam e que o apelo socorria-o, era uma claridade, era uma corda, um braço. (...) E a voz continuava insistente, semelhante à que rasga os pesadelos, rompe o jugo do sonho, desamarra" (OFP, 307).

clxv “Então, do céu, Atena desce. Enviou-a Hera, / dos braços brancos, que ama os dois, por ambos vela. / Por trás segura-lhe os cabelos louros, só / visível para ele; ninguém mais a vê" (II, I, 195-8) .

clxi 0 famoso duelo entre Aquiles e Enéias, na llíada, apresenta uma noção híbrida quanto ao destino. Certa predeterminação se mostra quando Poseidon subtrai da luta o jovem guerreiro e justifica 0 ato: “(...) Manda a M oira que ele escape, a fim / de que, priva de sêmen, não pereça a estirpe / de Dárdano (...)"(II, XX, 302-5). A responsabilidade humana pelo seu destino, porém, se faz presente, por mais paradoxal que isso seja. Depois de arrebatado sobrenaturalmente do campo de luta e posto em lugar inalcançável pelo adversário, Poseidon adverte Enéias a que não mais enfrente Aquiles, sob pena de morrer, mesmo que isso não seja o desígnio dos deuses. A ação dele também contaria. Enéias deveria fazer sua parte, ou seja, evitar a todo custo a mão poderosa de Aquiles: "Toda vez que o defrontes no campo de luta, / deves recuar, a fim de que não baixes, mesmo / à contra-M oira, ao paço de Hades. (...)"(II, XX, 335-7). No entanto, Dodds considera anacrônico falar sobre determinismo ou livre-arbítrio na obra de Homero, pois os gregos daquele tempo não detinham tais noções. Mas se opõe à idéia de que as personagens de Homero não teriam qualquer consciência da liberdade individual. Homero parece distinguir as ações individuais daquelas oriundas de deuses: "Perguntar se as pessoas são deterministas ou defendem a liberdade dentro da obra de Homero é, aliás, um fantástico anacronismo a questão jamais Ihe ocorreria, e se Ihe fosse apresentada seria muito difícil fazê-lo entender do que se trata" (DODSS: 2002, p. 15). Em nota de fim de texto (31), o estudioso explicitará melhor seu ponto de vista, dizendo que dois outros estudiosos da poética grega, Snell e Voigt enfatizam "que Homero não tem nenhuma palavra para designar decisão ou ato de escol ha". Referindo-se particularmente a Voigt, Dodds, porém, acrescenta: "Mas a conclusão de que nele ainda o homem não tem consciência da liberdade individual ou de algo como decisão individual me parece equivocada" e justifica: "O que eu diria é que o homem homérico não possui o conceito de arbítrio - 'vontade' (que curiosamente se desenvolveu tarde na Grécia) - e que, portanto, não pode haver tampouco o conceito de 'livre-arbítrio'. 0 que não impede o poeta de distinguir, na prática, as ações originadas no ego daquelas às quais ele atribui intervenção psíquica" (idem ibidem, p. 28).

clxvii Agamenon se desfaz de toda a sua prepotência e atribui seus atos a ate (louca paixão advinda dos deuses): “(...) Não sou culpado, / mas Zeus, a Moira, e a negronoctâmbula Erínia; / na ágora, eles cegaram-me os siso, funestos / Mas, que fazer? Perpassa um nume e perfaz tudo: / Ate, a filha maior do pai Zeus, atroz, multi- / enganosa. Pés lépidos, não pisa a terra ;/ anda sobre a cabeça dos homens e ao cabo / os arruína; um depois do outro, ela os burla e enreda" (II, XIX, 86-94).

clxviii Em relação ao conceito do destino sendo moldado exclusivamente pelos deuses, começamos a ver algumas incongruências entre as crenças de llíada e as de Odisséia. Por exemplo: Diferentemente de llíada, na Odisséia, os deuses não são os responsáveis por todas as ações dos seres humanos e as conseqüências que delas advém. A Odisséia inicia-se com a menção de que os guerreiros de Odisseu tiveram seu fim por conta de suas ações e sofreram as conseqüências de suas escolhas. Do líder, 0 narrador diz: "Os companheiros, porém, não salvou, muito embora o tentasse, / pois pereceram por culpa das próprias ações insensatas" (Od, I, 6-7). Os navegadores a serviço do herói itacense tiveram responsabilidade em seu destino, o que explica o narrador: "Loucos! Que as vacas sagradas do Sol Hiperônio comeram. / Ele, por isso, do dia feliz os privou do retorno" (Od, I, 8-9) . Depois que os companheiros soltam os ventos de Éolo, Odisseu volta à casa do deus e explica: "Desanimados ficamos no rude trabalho dos remos, / por culpa nossa; perdida a esperança da volta ali tínhamos" (Od, X, 78-9). A responsabilidade humana diante de seus atos aparece também na fala de Éolo, ao recepcionar os navegantes de volta. Após ouvir o relato de que os companheiros haviam soltado os ventos, Éolo expulsa Odisseu de suas terras dizendo: "Fora, depressa, desta ilha! 0 mais vil dos mortais és, decerto, I pois não me é lícito aqui receber nem enviar para a pátria / um indivíduo que os deuses beatos desta 
arte hostilizam / Vai-te! Tua volta demonstra a que ponto és por eles odiado" (Od, X, 72-5).

Evidentemente, Éolo está atribuindo culpa dos males a Odisseu: se tantos acontecimentos ruins lhe sobrevêm é porque ele é "o mais vil dos mortais" e, por isso, "odiado" pelos deuses. Mais à frente, Odisseu explicitará aos companheiros: "Caros amigos, não basta que um só, ou que dois, fiquem cientes I do que respeita ao destino que Circe preclara me disse. / Não; quero tudo contar-vos, porque procuremos a morte / conscientemente, ou possamos fugir do Destino funesto" (Od, XII, 154-7). Note-se que os navegantes poderiam evitar a morte ou procurá-la "conscientemente". Fugindo das sereias, Odisseu pede aos companheiros navegantes: "Vós, remadores, nos bancos sentados, as ondas profundas / com vossos remos batei, para vermos se Zeus nos concede / deste perigo fugir e da M orte escapar impendiosa" (Od, XII, 214-6). Os remadores precisavam remar para ver se Zeus concedia a libertação da morte; portanto, a parte dos homens deveria ser feita... De maneira análoga, muitos momentos desventurosos de Odisseu ocorrerão por conta de uma atitude sua. É por ter cegado 0 gigante Polifemo, filho de Posido (ou Poseidon), que o herói não logrará êxito em retornar direto à pátria. Chegando ao lar e disfarçado de mendigo, Odisseu é maltratado por Antínoo, o pior dos pretendentes e $o$ herói diz: “M as se as Erínias e os deuses protegem, realmente, os mendigos, / antes das núpcias Antínoo há de ser pela M orte atingido" (Od, XVII, 475-6). Já nos momentos em que se lança à vingança, Odisseu ouve de Liodes, um dos pretendentes, uma espécie de autodefesa e, como era próprio do caráter dos pretendentes co mo um to do, uma acusação contra os demais companheiros: "Por esses atos iníquos o triste Destino os alcança" (Od, XXII, 317), frase poética que será repetida na fala de Odisseu a Euricléia, a fiel ama, no verso 416. Mas, quanto às súplicas de Liodes, Odisseu responderá: "Não poderás (...) escapar do funesto Destino" (Od, XXII, 325) , ou seja, pela atitude gananciosa, irreverente e sacrílega dos pretendentes ao desrespeitar os fundamentos gregos do lar, da propriedade, da família e da religião, é que eles serão julgados e condenados. E Liodes era um deles... Os pretendentes, sabemos, são mortos pelo dono da casa e os parentes dos homens se reúnem com a intenção de vingá-Ios. 0 arauto Medonte - 'de sábios conselhos'(Od, XXIV, 442, 455, 462), todavia, Ihes dirá: "Por nossos crimes, amigos, agora tudo isso acontece", advertindo-os a porem um fim às reclamações para que não houvesse maior dano na cidade: "ninguém sobre si chame a sorte funesta". 0 homem pode também atuar contrariamente à vontade dos deuses e um exemplo dessa insurgência ocorre quando Atena, disfarçada de Iftima, a irmã de Penélope, Ihe diz: “Dormes, Penélope, com o coração por tal modo angustiado? / Não te consentem os deuses, que vivem em feliz existência, / tanto chorar e afligir-te; ao teu filho ainda está destinado / vir de tornada, porquanto ele em nada ofendeu aos eternos" (Od, IV, 804-7). Veja-se que os deuses não consentiam no choro de Penélope, mas ela chorava e sofria, portanto, ela detinha autonomia para escolher sua condição: não chorar ou chorar; não sofrer ou sofrer. E nos mesmos versos se apercebe a atuação divina em resposta às escolhas humanas: Telêmaco iria voltar porque não ofendera aos deuses, o que se deduz: nenhum erro, nenhum castigo. De todas essas considerações sobre o destino dos homens e sua responsabilidade nele, concluímos que na Odisséia, escrita aparentemente muito tempo depois da llíada, a religião grega assumia novos contornos em relação às crenças no destino, embora, ao remeter-se a personagens e acontecimentos narrados na llíada retome os seus valores, também prega que já não é pela vontade temperamental dos deuses que os heróis tem suas venturas ou desventuras, mas por al go que fizeram ou deixaram de realizar. Estaria aí nascendo o germe do livre-arbítrio? Deparamo-nos com uma Odisséia que defende a autonomia humana, e outra que se apóia na llíada, cujos pressupostos a esse respeito eram de que os deuses manobravam os homens quais manipuladores de títeres, como vimos. Como 0 narrador de llíada diz de Helena [seus feitos foram provocados por deuses, a fim de que os poetas tivessem assunto nas canções], o rei Alcínoo dirá que a guerra entre gregos e troianos foi obra da vontade dos deuses, a fim de servir como alimento para as narrativas dos homens: “Conta, também, 0 motivo de tanto afligir-te o imo peito / ao escutares desgraças de Tróia, dos Dânaos e Argivos. / Obra dos deuses foi tudo, que aos homens a ruína teceram, / para que nunca aos vindoiros faltasse matéria de canto" (Od, VIII, 577-80). Enfim, os homens têm que passar pelo que passam para servir de experiência a outros.

clxix Sobre a noção de responsabilidade dos homens sobre seu destino, em Eneida, Virgílio parece inserila, ou pelo menos a questiona, no episódio em que, percorrendo a cidade de Tróia em chamas, vê sua cunhada, Helena, tentando se ocultar e proteger a vida. A reação do guerreiro é de ódio e ele pensa em matá-la, vingando-se, em nome de todos os troianos, já que a grega dera início aos conflitos ao deixar 0 esposo para seguir Páris. Mas, o crime é impedido por Vênus, que atribui a culpa dos atos da ex-esposa 
de Menelau a Juno. A eterna rival tudo provocara (inclusive a traição de Helena) com a intenção de destruir Tróia. 0 poeta também insere duras acusações (dirigidas ao herói) na fala de Dido.

Assim, na Eneida, o destino humano é colocado em uma base dúplice. 0 herói é um ser homem incomparável, fiel aos deuses, íntegro, valente, belicoso, um semideus, protegido por Vênus, sua mãe; tendo o Destino a dirigi-lo e sendo completamente submisso ao mesmo (portanto, não independente, destituído de plena autonomia, sem a capacidade do que entendemos por livre-arbítrio).

clxx Suzana havia dito: "- Agro e magro destino - (...) " (OFP, p. 33) e Hutá havia falado: "Enfim, cada qual com sua sina." (OFP, p. 40).

clxxi Huisman e Vergez nos fazem lembrar os pressupostos de Sartre aos quais que tão bem se coaduna a ação de Bernardo: "Sartre observa que uma situação não é intolerável em si, ela assim se torna porque um projeto de revolta conferiu-lhe este sentido. Poder-se-ia, com outro projeto, considerar a situação como uma prova santificadora, como a ocasião bendita para se purificar e oferecer seus sofrimentos a Deus. Ao projetar minhas intenções, minhas expectativas do futuro sobre a situação atual, sou eu quem, livremente, transforma esta em motivo de ação. São meus projetos livres que dão uma significação às situações. 0 mundo não é senão o espelho de minha liberdade. Este ultrapassamento de uma situação presente por um projeto futuro é o que Sartre denomina de transcendência" (HUISM AN, VERGEZ: 1982, p. 411-2).

clxxii Theasurus linguae graece. CD ROM \#D. PHI, Pre-mastering by Packard Humanities Institute, frag. 119.1-120.1. Heráclito se opõe à noção de destino pré-estabelecido, mas Dodds comenta: “Heráclito protesta em vão que 'o caráter do homem é o seu destino' (...) mas na verdade ele não consegue vencer a superstição." (DODDS, 2002, p. 49).

clxxiii ARISTÓTELES: 1999, VI, 32, p. 44.

clxxiv ARISTÓTELES, HORÁCIO, LONGINO: 2005, VI, p. 26.

clxv ARISTÓTELES: 1999, p. 43.

clxxvi Osman Lins assume publicamente que o grande modelo para Bernardo foi o tio, como se vê em entrevista concedida à revista Status, em março de 1975 e publicada no livro Evangelho na taba: Outros problemas inculturais brasileiros, uma compilação dos artigos e entrevistas do autor, reunidas por sua segunda esposa, Julieta de Godoy Ladeira: "A solidão e a estreiteza dos meus primeiros anos, atenuados pelas presenças de Laura, irmã do meu pai (que é transfigurada, a Teresa de 0 fiel e a pedra), e da minha avó paterna, Joana Carolina, cuja vida agreste e, por assim dizer, simbólica, narrei em outro livro, foram ainda compensadas pela presença de um homem como não houve muitos no mundo: Antônio Figueiredo. Para quem não o conheceu, isto é apenas um nome. Param mim, é tudo o que pode sonhar o coração de um menino. Lá está ele, transformado, também em 0 fiel e a pedra, com o nome de Bernardo Vieira Cedro, vivendo aventuras muito semelhantes a algumas que enfrentou realmente. Era um mão aberta, um homem leal, confiante, alegre e nunca soube, estou certo, que diabo era o medo. A não ser, talvez, quando adoeceu para morrer, pois amava de verdade a vida" (ET, p. 189). Todavia, ao compor o caráter do protagonista de seu romance de 1961, lança mão de outros heróis, dessa vez, literários.

clxxvii $\mathrm{Na}$ condição de autonomia o indivíduo determina suas leis. Na de heteronomia, alguém ou algo exterior comandam as ações da pessoa. Conferir os pressupostos de Kant, por exemplo, os quais abordam profundamente a autonomia da vontade - o princípio da verdadeira moral.

clxxviii "Sua ira, a força de seu desafio, concentrara-os no ato temerário, que Ihe parecera indispensável e simples, de abrir a porta" (OFP, 184).

clxix Aquiles mesmo conta de seu destino duplo: “(...) Tétis, madre, / me avisou: um destino dúplice fadou-me / à morte como termo. Fico e luto em Tróia: / não haverá retorno para mim, só glória / eterna; volto ao lar, à cara terra pátria: / perco essa glória excelsa, ganho longa vida; / tão cedo não me 
assalta a morte com seu termo" (II, IX, 410-5). Aquiles amava a vida, o que se vê me frases como esta: "(...) Pois nada como a vida." (canto IX, v.401, p. 351). Por ocasião da embaixada enviada por Agamenon, para tentar convencer Aquiles a retornar para a guerra, um dos componentes, Fênix, antigo protegido do rei Peleu e uma espécie de "segundo pai" do herói, aconselha-o a "domar" a ira e ao mesmo tempo lembra de que até os deuses mudam de idéia em suas ações e intentos: "Doma, Aquiles, teu ânimo!Tanta aspereza / não te vai bem. Os deuses mesmo são flexíveis." (II, IX, 497-8).

clxxx Olhando do ponto de vista das ações dos que o crucificaram e não levando em conta a condição típica de Sua entrega como propiciação pelos pecados da humanidade.

clxxi HOMERO: 1960, Introdução, p. 6.

clxxxii 0 canto surge como elemento relevante na Odisséia. Ao chegar a Esparta, Telêmaco presencia a festa de casamento dos filhos de Menelau e Helena. Note-se a ênfase no canto e dança: "(...) Cantava entre todos o aedo divino, / ao som da cítara, ao tempo, também que dois salteadores, / cabriolavam, seguindo o compasso, no meio de todos." (Od, IV, 179). Odisseu narra sua chegada à ilha de Circe, a deusa que se entretinha no canto: "Fomos depois, aportar à llha Eéia, onde tinha morada / Circe, de tranças bem feitas, canora e terrível deidade" (Od, X, 135-6). Circe tece ao ritmo de sua canção: "e Circe ouviram, que dentro cantava com voz amorável / e no seu ritmo tecia uma tela imortal, como as deusas I fina e graciosa costumam fazer, de brilhante textura" (Od, X, 221-3). O som perturba os companheiros de Odisseu: "Caros amigos, lá dentro alguém tece, meneando-se ao canto, / num grande tear, de tal forma que, à volta, o chão todo ressoa" (Od, X, 226-7). Há também a narração das sereias. Odisseu conta sobre o fato: "Somente a mim concedeu que as ouvisse (...)" (Od, XII, 160). A Odisséia fala de Fêmio e Demódoco, dois aedos que exercem parte atuante na narrativa. Veja-se como aborda 0 primeiro: "Uma belíssima cítara traz logo o arauto e a coloca/ na mão de Fêmio, que, contra a vontade, os festins alegrava. / Preludiando na cítara, ao canto dá aquele princípio" (Od, I, 153-5). 0 próprio artista defende que as canções sempre foram inspiradas pelos "deuses" e remetiam, ou eram dedicadas a deuses e ontem, isto é, registravam e eternizavam os feitos de homens e deuses. Através de Fêmio, Homero valoriza a arte, a poesia (literatura), o que se ratifica nas palavras de Telêmaco, tentando aplacar o desejo dos pretendentes, de possuir imediatamente Penélope (e os bens...): "(...) ninguém faça bul ha importuna, / pois não há nada de mais belo que um canto escutar delicioso, / tal como os deste cantor, que semelha na voz a um dos deuses." (Od, I, 369-71). Odisseu, ele mesmo um narrador, mostra seu respeito aos artistas e Fêmio é salvo, juntamente com o arauto Medonte. Demódoco é 0 cantor do banquete do rei Alcínoo e parece gozar de excelente reputação entre os ouvintes, conforme se vê nos versos a seguir: "(...) Mandai vir o divino Demódoco, / 0 aedo que obteve dos deuses poder deleitar-se com a música, / como lhe pede o furor, que no peito a cantar o estimula" (Od, VIII, 43-5) ou "Isto narrava o famoso cantor" (Od, VIII, 83). É também chamado "o divino Demódo co", o "cantor divinal" (Od, VIII, 43, 62). Como no caso do aedo de Menelau e de Fêmio, Homero atribui, também a Demódoco a "inspiração divina": "(...) 0 cantor, por um deus inspirado, dá logo começo" (Od, VIII, 499). Demódoco cantava e acompanhava suas cantigas com instrumento musical: "Tragam, também, sem demora a Demódoco sua harpa sonora" (Od, VIII, 254) e, apesar da notável aptidão na área da música, 0 aedo era deficiente visual. Odisseu se encanta com as narrativas de Demódoco: "Dessa maneira cantava o notável aedo. Em sua alma / muito folgava Odisseu ao ouvi-lo cantar (...)"(Od, VIII, 367-8). O herói elogia a excelência narrativa do aedo: "Mais do que a todos os outros mortais, te venero, ó Demódoco! / Foste discíp'lo das M usas, as filhas de Zeus, ou de Apolo? / tão verazmente cantaste as desgraças dos homens aquivos, / quanto fizeram, trabalhos vencidos, e o mais que sofreram, / como se o visses tu próprio, ou soubesses de alguém fidedigno" (Od, VIII, 487-91). Odisseu pede que Demódoco cante de acordo com os fatos: "Caso consigas cantar isso tudo de acordo com os fatos, / logo darei testemunho perante 0 universo dos homens / que recebestes de um deus benfazejo a divina cantiga". (Od, VIII, 4968). Demódoco satisfaz os anseios do ouvinte, o qual demonstra o intenso prazer de prazer de ouvir aquelas narrativas: "É delicioso, de fato, podermos ouvir tão sublime / e inolvidável cantor, cuja voz se assemel ha à dos deuses" (Od, IX, v. 3-4).

clxxxiii Odisseu e Penélope contam suas aventuras e desventuras um ao outro, após o retorno do herói: "Narra Penélope quanto sofrera durante esse tempo, / (...) / Por sua vez, o divino Odisseu lhe narrou, 
também, quantas / dores aos homens causara e os trabalhos que havia sofrido (...)"(Od, XXIII, 302, 3067).

clxxxiv Que os viajantes têm mais histórias para contar é o que nos lembra Walter Benjamin, o qual, referindo-se à diferenças entre os narradores sedentários e os viajantes, quando diz: "Quem viaja tem muito que contar" (BENJAM IM: 1994, 198). 0 estudioso preconiza que as melhores narrativas se aproximam das orais: "E, entre as narrativas escritas, as melhores são as que menos se distinguem das histórias orais contadas pelos inúmeros narradores anônimos" (BENJAMIM: 1994, p. 198).

clxxxv “Ela [a narrativa] tem sempre em si, às vezes de forma latente, uma dimensão utilitária. Essa utilidade pode consistir seja num ensinamento moral, seja numa sugestão prática, seja num provérbio ou numa norma de vida - de qualquer maneira, o narrador é um homem que sabe dar conselhos. (...). Aconselhar é menos responder a uma pergunta que fazer uma sugestão sobre a continuação de uma história que está sendo narrada. (...). O conselho tecido na substância viva da existência tem um nome: sabedoria. A arte de narrar está definhando porque a sabedoria - o lado épico da verdade - está em extinção. (...). 0 primeiro indício da evolução que vai culminar na morte da narrativa é o surgimento do romance no início do período moderno" (BENJAMIM : 1994, p. 201).

clxxxi Os salmos eram um tipo de composição poética feita exclusivamente para ser cantada pelos cantores do templo judaico nos rituais religiosos do Israel antigo. Os poemas evocavam auxílio, salvação e proteção divinos, expressavam gratidão ou rogavam a punição dos inimigos. Os versos, ricos em paralelismos, eram úteis à repetição pelos fiéis e se faziam acompanhados de instrumentos como 0 kinnor, espécie de harpa ou lira; o nebel - ou saltério - espécie de alaúde; o halil, flauta de junco, madeira ou osso que a maioria das pessoas comuns tocava; o queren e o shofar, tipo de trompa feita de chifre de carneiro; a hazorzra, trombeta de metal; o menaanim, instrumento de percussão; o meziltaim, címbalos de cobre; o tof, espécie de tamborim e outros que os músicos levitas tocavam tão bem (ALEXANDER: 1987, p. 250-2).

clxxxvii 0 canto assume proporções instigantes nos capítulos XXIX até o XXXII, que abordam as desventuras de Teles Sá. 0 jovem advogado, em seu momento de maior ansiedade em face da mais auspiciosa decisão diante do processo que têm nas mãos, ouve um trecho da famosa música de Catulo da Paixão Cearense, Luar do Sertão, entoado por algumas alunas de um colégio interno:

"Vozes de mulher surgiram, confundiram-se ao longe. Invisível na noite, talvez à margem do açude, um grupo de internas começou a cantar.

A lua nasce

por detrás da verde mata..." (OFP, 164)

Ao ouvir o canto, diz o narrador que Teles Sá tem uma reação imediata, de enlevo e abstração total da dura realidade que o esmagava, até de desejo de irmanar-se às jovens cantoras e de alçar a voz com 0 belo coral: "O advogado parou. Um vulto surgiu no fim do muro, veio andando; 0 eco dos passos ressoava na calçada. A noite era negra, quente, o pó subia quando os veículos passavam, mas a canção fazia despontar uma lua na alma das cantoras. Teles parou; esquecera tudo, quisera estar com elas." 'OFP, 164). Para as mocinhas, de certa forma aprisionadas, a música era um modo de evasão da realidade, transportando-as a um outro lugar, em uma outra noite, e fazendo-as, quem sabe, assumir outras formas, que não as suas. Em vez da reclusão entre as paredes do internato, a liberdade das matas inundadas com a luz clara da lua; em lugar da rotina urbana e rígida, a idealizada beleza nacional. Ao mesmo tempo, a canção faz Teles esquecer tudo e esse tudo é revestido de denso negror: sua própria sensação de inutilidade, o arrependimento de não ter sido mais ousado, no passado, a mediocridade de sua vida atual, 0 assédio de Nestor e outras circunstâncias depressoras que 0 angustiam, amedrontam e entorpecem. A "luz" da lua imaginada, porém, tem sua função restrita a um breve lapso de tempo. Em seguida ao momento de transcendência, o jovem advogado vê um vulto se aproximar e esse é, nada mais nada menos, que o grande algoz que se achega para atormentá-lo e determinar seu fim. Evasão, catarse, prazer, todos esses elementos se acham ligados à música e à letra, ou seja, há uma narrativa nos poemas musicados, que nos levam para além de nosso momento e do tempo em que estamos vivendo. Teles Sá, de certa forma, remete a Odisseu, alegrando-se ou derramando lágrimas ao ouvir as canções de Demódoco. 
clxxxviii No capítulo XIV, o exórdio traz um trecho de canção: “Ascânio viaja a cavalo. Chove, chuva." (OFP, 77) Nesse ponto do romance, é-nos apresentada a simplicidade e a fé de Antônio, o homem bom e puro que se entregava à amizade com a fidelidade de um Sancho Pança. Aqui, o prestativo Chá é 0 encarregado de ir a Vitória e buscar o menino Ascânio, a fim de que o pequeno passasse uns dias de férias com os tios Bernardo e Teresa. Antônio coloca o garoto no lombo de seu cavalo e partem, ambos, para o Surrão. No caminho, chuva torrencial os pega de surpresa. Antônio incentiva Ascânio a cantar uma melodia que, segundo suas crenças, tinha o poder de afugentar os raios. Todavia, o trecho da cantiga também demonstra a gratidão do homem simples do campo pelas bem-vindas chuvas. Note-se que, mesmo sob forte chuva, Antônio não pragueja ou lamenta, mas canta lembrando as benesses do temporal: "Chove, chuva / pra nascer capim.." (OFP, 78). 0 urbano e temeroso Ascânio, porém, demonstra o medo da tormenta: "- Pode cair um raio na gente." Antônio Chá replica, como o otimismo de sempre, acreditando na força do canto (e da fé) para o livramento dos males: "- Canta, besteira, pra espantar o corisco" e repete o refrão cantado antes: Chove chuva, / pra nascer capim...".

clxxxix No primeiro capítulo, destoando do silêncio das casas e da rua na noite de sofrimento em que José morre, um homem passa cantando: "... tudo continuou em silêncio, a casa, as ruas desertas. Um homem passou cantando, foi embora, a voz e o rumor de seus passos se perderam." (OFP, 3). É impossível não ligar essa imagem visual e sonora - um homem que surge do nada e desaparece noite adentro entoando uma cantiga - ao caráter quase de evanescência de que é dotada a vida humana. Outro exemplo do canto a emol durar um dilema de alma, surge na passagem de uns homens pelo Surrão, um animado grupo de bêbados a cantar alegremente, na liberdade e irmandade quase infantil dos ébrios: "De súbito, na placidez da noite, dois ou três homens se aproximaram, cantando. A porteira foi aberta brutalmente. Houve risadas e novamente a cantiga" (OFP, p. 48). 0 sisudo Bernardo, praticamente incapaz de sorrir, cantar ou embriagar-se com amigos, tem a sensação de liberdade das viagens advinda pela canção. Repentinamente, o barraqueiro percebe invadir sua alma um forte desejo de se jogar pelo mundo afora, nas viagens que fazia antes de se casar com Teresa: "Ir com eles, com aqueles homens que cantavam e que talvez estivessem embriagados. (...) Ainda parecia ouvir a canção, as vozes ásperas dos homens." (OFP, p. 49). Inspirado em Demódoco, Osman Lins insere em 0 fiel e a pedra dois cegos cantores. 0 primeiro, um cego mendigo, canta na praça defronte ao armazém em que Nestor e seu funcionário conversam. 0 tema do colóquio é, exatamente, a história de um cego. "Um cego, no pátio, começou a cantar. Sua voz alongava-se nas últimas vogais dos versos, rompia-se, retomava com ardor o outro verso, detinha-se de novo e o gemido final da estrofe se apagava, tenso, longo. Um níquel era agitado com mecânico rigor, numa bacia de estanho" (OFP, 138). Assim como Ramalho insere pitadas de depoimentos para justificar a passível credibilidade da história [o empregado jurava que seu pai testemunhara tudo], o cego modula a voz para acompanhar os picos emotivos de sua narrativa. E embora 0 interlocutor de Ramalho se demonstrasse surpreso e até incrédulo quanto a uma atitude contra um vel ho cego e sua reação, ninguém dava a mínima para o cego real e faminto no pátio: "A voz do cego retomou o seu apelo, impassível ante a indiferença do pátio" (OFP, 138). Terminada a narração do episódio do cego, o cego da praça encerra sua narrativa musicada: "Cessou mais uma vez a toada monótona do cego, ficou o som do níquel na bacia. 0 sol inundou o pátio, a claridade bateu nas paredes sujas, deu um tom amarelaço à pele de Nestor. Houve um surdo lampejo nos metais do cofre" (OFP, 140). O outro cego cantor aparece quase no final da narrativa, quando Ascânio vai para a praça. $\mathrm{Na}$ cena multicolorida e multi-sonorizada, caracterizada por bandas, roda gigante, um sanfoneiro idoso e acompanhado de uma criança, que também tocava um instrumento musical: “(...) um velho tocava sanfona, um menino acompanhava-o ao reco-reco" (OFP, 279). Adiante, a informação de que se trata de um cego : "(...) o carrossel girou, giraram o reco-reco e a sanfona do cego e no giro ainda lento outros sons sucederam-se: a trompa rouca do picolé, o assovio do pirolito, o triângulo do cavaquinho e um bater de moedas na bacia de um cego, sua lastimosa cantiga" (OFP, 279).

${ }^{\mathrm{cxc}}$ Um canto soa como uma espécie de fundo musical para o tenso diálogo entre essa personagem e sua mãe, quando da notícia sobre a mudança para o Surrão. Suzana critica Bernardo por se ver prestes a "perder" a filha e censura a jovem por não haver escolhido melhor seu marido. Nesse embate psicológico, ouve-se uma canção e a frase que a antecede também é curiosa. 0 narrador diz que "(...) alguém pôs-se a cantar num tom malicioso" (OFP, 36): "Lá foi que nasceu o sol, / lá nasceste tu também. / És da vida o arrebol, / eu confesso que te quero bem. / Nesta aldeia amiga..." Analisando algumas palavras dessa canção, encontramos instigantes pontos de contato entre o que é cantado e 0 
cerne do episodio. Por exemplo: 0 advérbio "Lá" está relacionado a um local que é chamado "aldeia amiga" e esse lugar é onde o sol nasceu. Nessa "aldeia amiga" também nasceu o ser amado, metaforizado pelas cores (avermelhadas) do alvorecer. Enfim, a música fala de um local - uma cidade amiga, amiga porque lá nascera 0 amado (e o sol); fala do ser amado, que é como 0 sol que ilumina a vida daquele que o ama, e como a arrebol, trazendo todos os dias uma perspectiva de renovação e continuidade. Afinal, a canção coroa o pensamento de Teresa, de que onde estivesse com o esposo, aí estaria bem. A poesia expressa na música interliga-se ao futuro de Teresa, ao lado de Bernardo - o seu arrebol, ou o renascer de outro dia. Tudo pode acontecer nesse novo dia, mas a alvorada sempre chegará revestida de esperança, conforme se verá no amanhecer descrito ao final da narrativa, em que Teresa verá Bernardo revestido das "asas" de nuvens, o grande pássaro renascido. Por fim, o ser amante confessa publicamente o amor. A música parece estar reafirmando a Suzana, daí o tom malicioso, de que de nada adiantará usar de argumentos críticos ou chantageadores para demover a filha da dedicação que ela devota ao esposo, mas o diálogo na tarde chuvosa é emblemático apontando para 0 fato de que a sufocante relação mãe-filha carecia ser revista. Depois da conversa, a chuva passa e Suzana pergunta, então, quando a filha pretende partir. Teresa responde que se irá quando o marido assim o desejar, talvez naquela mesma semana, acrescentando que pelo Carnaval gostaria de estar longe, surpreendendo-se, ela mesma, com sua firmeza de propósitos, com o "vibrante ardor que pusera na resposta. Com a inesperada vibração que adquirira sua voz" (OFP, 36).

cxci Fazendo uma analogia às obras ficcionais de Dostoiévski e de outro famoso escritor russo, Tolstoi, com a intenção de explicitar melhor o conceito do romance polifônico e do dialogismo, Bakhtin diz que, se o primeiro fosse 0 autor do conto As Três Mortes, o leitor veria um resultado diferente: "Construiria o todo da obra como um grande diálogo, ao passo que autor atuaria como organizador e participante desse diálogo, sem reservar-se a última palavra, isto é, refletiria em sua obra a natureza dialógica da própria vida e do próprio pensamento humano"(BAKHTIN: 1998, p. 73).

cxcii Nem mesmo a dialética de Hegel pode ser a máxima para uma discussão caracterizada pela multiplicidade de idéias, conforme o que se lê a seguir: "O dialogismo, que deve muito a Hegel, não pode, no entanto, ser confundido com a dialética hegeliana que supõe uma tríade, logo, uma luta e uma projeção (ou superação), que não transgride a tradição aristotélica, fundada na substituição e na causa. 0 dialogismo substitui esses conceitos ao absorvê-los ao conceito de relação, e não visa a uma superação, mas a uma harmonia, implicando sempre uma idéia de ruptura (oposição, analogia) como transformação" "xcii (KRISTEVA: 2005, p. 94).

cxciii Schüler diz que nas epopéias homéricas, ao invocar as musas, logo no início do poema, o poeta reconhece sua dívida à tradição (SCHÜLER: 2004, 12). Assim estaria laborando Osman Lins, pelo visto. 